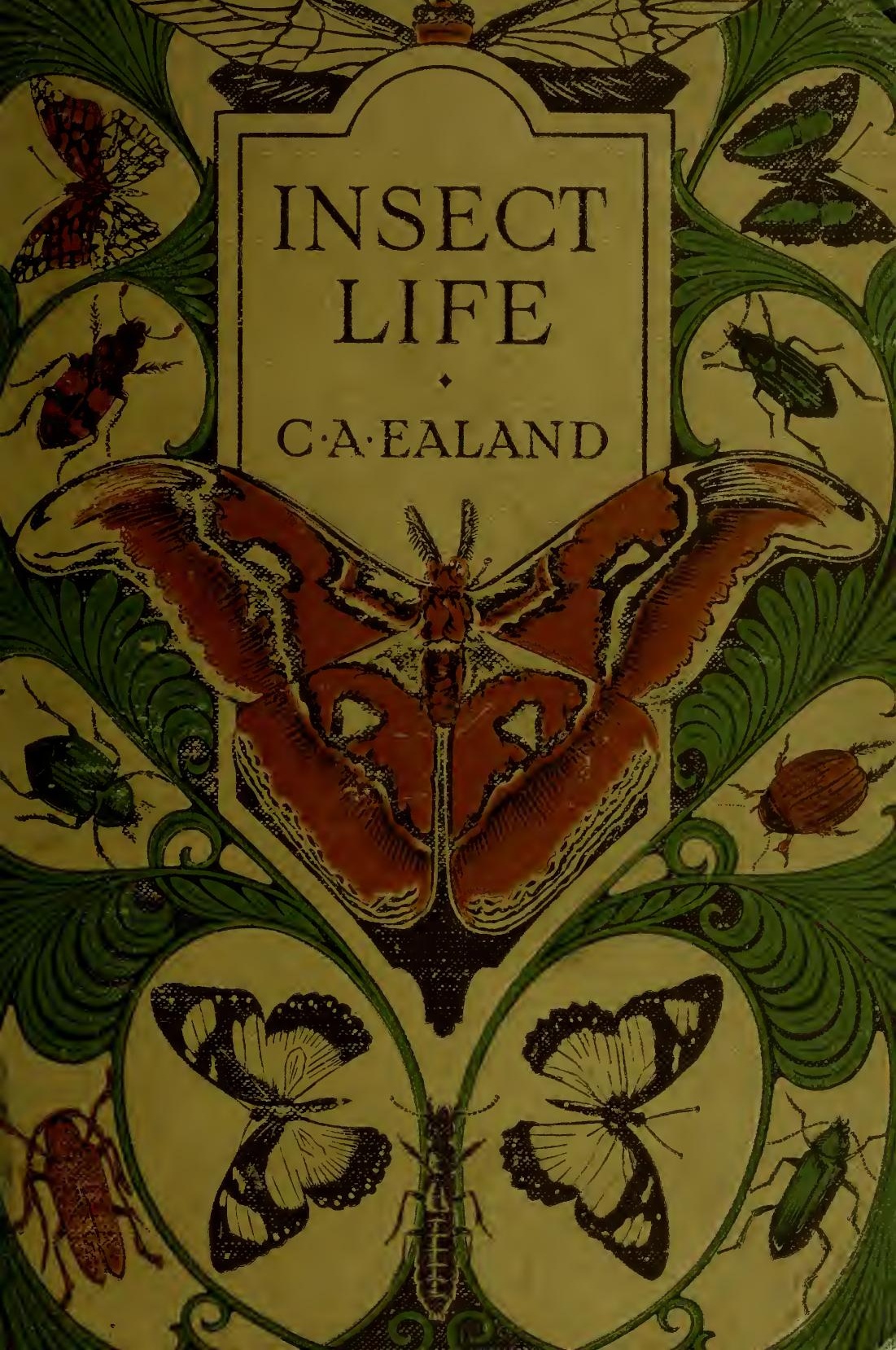




\section{Private Property of \\ Z. P. METCALF \\ No.}

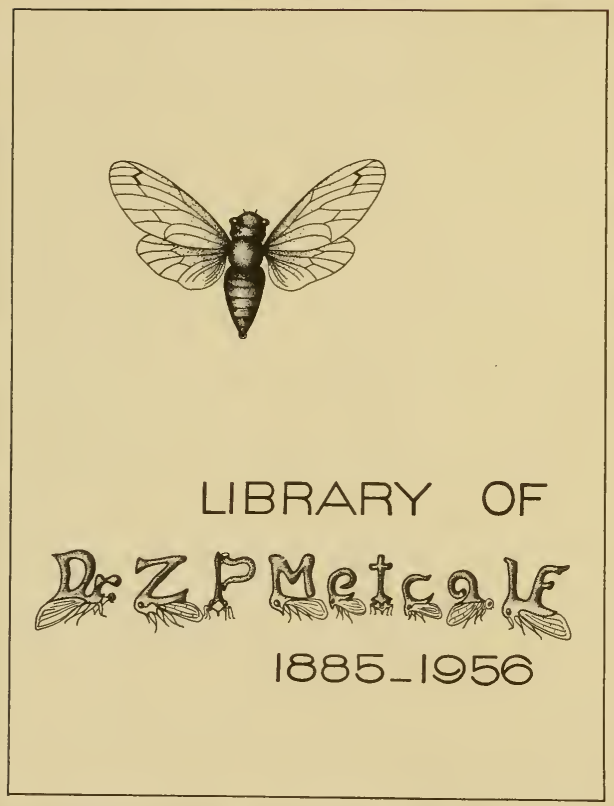




\section{Private Property of \\ Z. P. METCALF \\ No._ـ}



INSECT LIFE 


\title{
LIFE AND LOVE OF THE INSECT
}

By J. H. FABRE. Translated by Alexander Teixeira DE MATios. Containing 26 Illustrations, $I 1$ of them full-page from Photographs. Price 5s. net (by post 5s. 4d.).

"Rarely have we come across a book on natural bistory written so attractively. He invests his subject with a fascination which should attract many readers who are now outside the ranks of students of natural history. The illustrations are excellent and most illuminating." -County Gentleman.

\section{HIGHWAYS AND BYWAYS OF THE ZOOLOGICAL GARDENS}

By CONSTANCE INNES POCOCK. Containing 32 fullpage Illustrations from Photographs and a Frontispiece in colour. Small square demy 8 vo., cloth, price $6 \mathrm{~s}$. net.

Extract from a Press Opinion.-" "And so, with a profusion of 'domestic' touches such as these, Mrs. Pocock carries us through the principal sections of the Gardens in her attempt to-as she des ribes it- carry the Zoological Gardens to those who are unable to go to them.' In that description there is something lacking of justice to herself, for undoubtedly those who can go to the Gardens will find the pleasure attached to their visit greatly enhanced by a previous perusal of these pages."-Horse and Hound.

\section{THE ZOO}

By A. W. PETERS. In the "ARtists' Sкetch Book" Series. Large square demy 8vo., with Artistic Covers and Wrappers, bearing a design by the artist and containing 24 reproductions in facsimile from pencil drawings.

Difficulties of reproduction have hitherto hindered the employment, for illustrative purposes, of the pencil, which artists have always found the most sympathetic and responsive medium at their command for sketching purposes. In the "Artists' Sketch Book" Series the publishers venture to think they have successfully overcome these difficulties.

\section{PUBLISHED BY}

A. AND C. BLACK, LTD., 4, 5 AND 6 SOHO SQUARE, LONDON, W. I

\section{AGENTS}

\author{
AMERTCA _.. THE MACMILLAN COMPAYY \\ 64 \& 66 FIFTH AVBNUE, NEW YORK \\ AUSTRALASIA . . OXFORD UNIVERSITY PRESS \\ 205 FLINDERS LANE, MELBOURNE \\ CANADA .... THE MACMILLAN COMPANY OF CANADA, LTD. \\ ST. MARTIN'S HOUSB, 7O BOND STRBET, TORONTO \\ DELA . . . . MACMILLAN \& COMPANY, LTD. \\ MACMILLAN BUILDING, BOMBAY \\ 300 BOW BAZAAR STREBT, CALCUTTA
}



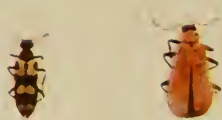

2

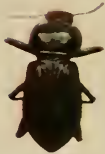

6
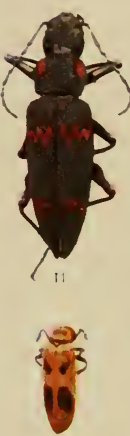

16

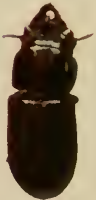

21

7

17

22

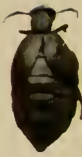

3
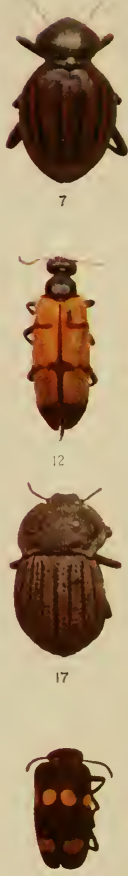

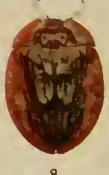

8

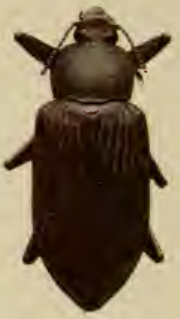

13

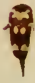

18

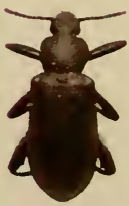

23

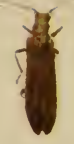

4

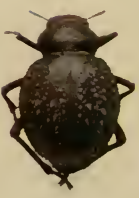

9

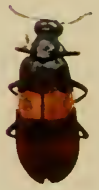

14

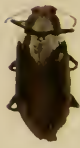

10

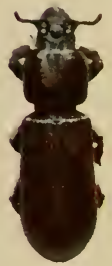

15

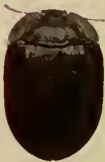

19
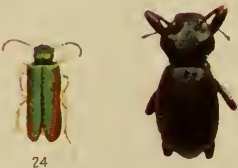

25
1. Mylabris capensis

2. Pyrochroa coccinea

3. Nelue proscarabaus

4. Calopus serraticornis

5. Zunitis quadripunctata

6. Hypaulax ovalis

7. Psammodes spinola

8. Helaus Hopei
7. Pinelıa anguata

10. Camaria sp.

11. Zophobus sp.

12. Mylabris trifasciata

13. Nictobates gigas

14. Mylabris transversalis

15. Chiroscelis passaloides

16. Cantharis quadrimaculata

17. Anumalipes dentipes is. Mordella periara

19. Pterulielitus sp.

20. Rhipiphorus sp.

21. Phrenapates bennetii

2.2 Tetraonyx sexguttatus

2.3 Odontopus cupreus

24. Cantharis dives

25. Cuelocnemis obesa 
INSEGT LIFE BY C. A. EALAND, M.A., WITH 74. FULL-PAGE ILLUSTRATIONS 24. BEING FROM PHOTOGRAPHS BY THE AUTHOR AND 50 IN COLOUR FROM NATURE

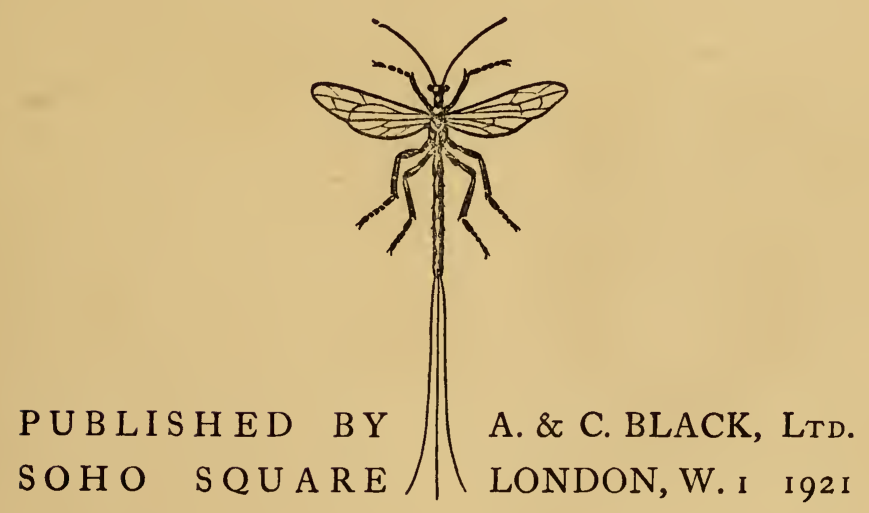





\section{INTRODUCTION}

“InSECt Life” breaks new ground. It is an attempt to provide a textbook of Entomology, useful alike to the serious student and to the reader who takes up the subject as a hobby.

As far as possible technicalities have been avoided, but the probable utility of the book to teachers has not allowed of them being altogether eliminated. The more important species of a very large number of families have been dealt with; it is clearly impossible, however, in a book of but three hundred odd pages, to cover the vast field of present-day Entomology.

'To my publishers I am indebted for many kindnesses in the production of the book. To Messrs. Jansen I express my appreciation for the loan of many specimens illustrated in "Insect Life."

LoNDON, 1921.

$$
\text { C. A. E. }
$$





\section{CONTENTS}

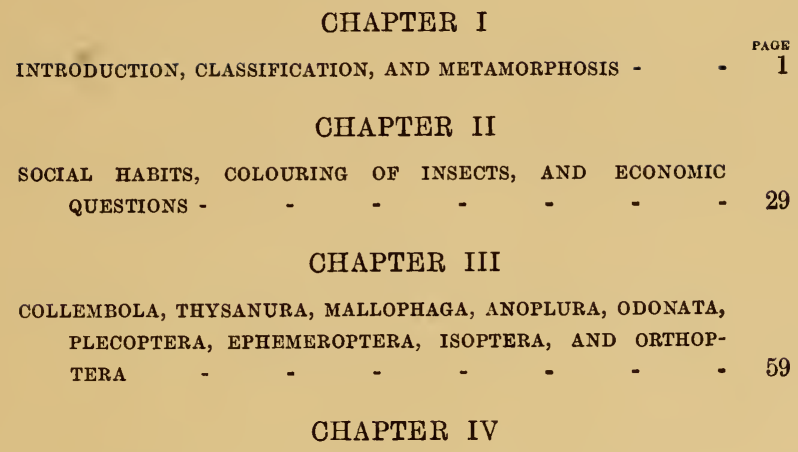

\section{CHAPTER III}

COLLEMBOLA, THYSANURA, MALLOPHAGA, ANOPLURA, ODONATA, PLECOPTERA, EPHEMEROPTERA, ISOPTERA, AND ORTHOPTERA

CHAPTER IV EUPLEXOPTERA, EMBIOPTERA, PSOCOPTERA, THYSANOPTERA, RHYNCHOTA

CHAPTER V

PLANIPENNIA, TRICHOPTERA, AND LEPIDOPTERA

- $\quad-127$

CHAPTER VI

COLEOPTERA AND STREPSIPTERA

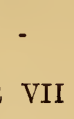

CHAPTER VII

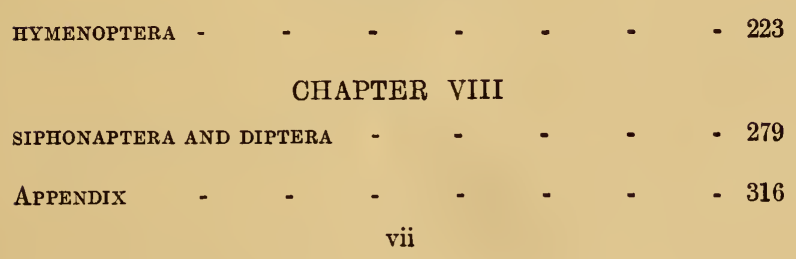




\section{LIS'T OF FULL-PAGE PLATES}

\section{MOSTLY IN COLOUR}

Those marked with an asterisk (*) are in black and white

PLATE

I. MYLABRIS CAPENSIS, PYROCHROA COCGIVEA FACING PAGE TWENTY-THREE OTHER BEETLES - Erontispiece

*II. LAPPET MOTH AT REST AMONG DEAD LEAVES GIANT COCKROACH - $\quad$ - $\quad-\}$ - 24

III. A GROUP OF DRAGON-FLIES - - $\quad$ - 66

*IV. STICK INSECT MANTIS $\quad-\quad-\quad+\quad-81$

*V. HEAD OF MANTIS

*VI. HEAD OF STICK INSECT, HIGHLY MAGNIFIED * 88

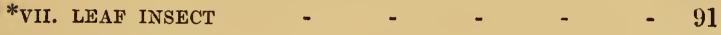

*VIII. NEW ZEALAND CRICKET - $\quad$ - $\quad$ - $\quad$ - 94

*ix. giant water BUG - - $\quad$ - $\quad$ - 113

* $\mathrm{X}$. CICADA $\quad$ - $\quad$ - $\quad$ - $\quad$ - $\quad$ - 115

IX. A GROUP OF HOMOPTERA - - - $\quad 116$

*xiI. hEAd OF CICADA, UNDER SIDE, highlY MAGNIFIED 118

*XIIr. LANTERN FLY - - - - $\quad$ - $\quad$ - $\quad$ - 120

*xiv. a Membracid Which mimics a THORN - 123

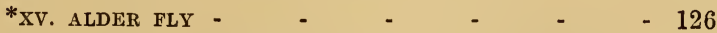

XVI. ORNITHOPTERA BROOKIANA, MALE AND FEMALE - 129

XVII. ORNITHOPTERA HEPHASTUS, MALE AND FEMALE - 132

ix 
PLATE TICING PAGE

XVIII. THAIS RUMINA, LASIOCAMPA TRIFOLII AND EIGHT OTHER BUTTERFLIES - $\quad$ - $\quad$ - $\quad$ - 136

XIX. EPICALIA NUMILIA, PAPILIO SARPEDON AND SEVEN OTHER BUTTERFLIES -

XX. VANESSA URTICA (SMALL TORTOISESHELL) OVA, LARV \&, PUPA AND IMAGO - $\quad$ - $\quad-140$

XXI. VANESSA ATALANTA (RED ADMIRAL), VANESSA CARDUI (PAINTED LADY) AND THREE OTHER BUTTERFLIES -

XXII. MELIT AA CINXIA (GLANVILLE FRITILLARY), MELITAAA ATHALIA (HEATH FRITILLARY) AND FIVE OTHER BUTTERFLIES

XXII. KALLIMA INACHIS (A LEAF BUTTERFLY) • 147

XXIV. COLIAS EDUSA (CLOUDED YELLOW), GONEPTERYX RHAMNI (BRIMSTONE) AND SEVEN OTHER BUTTERFLIES - $\quad$ - $\quad$ - $\quad$ - $\quad$ -

XXV. MORPHO ACHILLES - - - - - 150

XXVI. MELANARGia galathea (MARBLED WHITE), EREBIA EPIPHRON (MOUNTAIN RINGLET) AND EIGHT OTHER BUTTERFLIFS

XXVII. COENONYMPHA PAMPHILUS (SMALL HEATH), THECLA RUBI (GREEN HAIRSTREAK) AND TEN OTHER BUTTERFLIES -

XXVIII. DELIAS PYRAMUS, TERACOLUS JOBINA AND SEVEN OTHER BUTTERFLIES - - $\quad$ - $\quad$ - 156

XXIX. PALILIO MACHAON (SWALLOW TAIL), APORIA CRATAGI (BLACK VEINED WHITE) AND SEVEN OTHER BUTTERFLIES -

XXX. PAPILIO CENEA (RED VARIETY), (MALE AND FEMALE) AND THREE OTHER BUTTERFLIES - $\quad-161$

XXXI. LYCANA BELLARGUS (CLIFDEN BLUE), LYCAENA CORYDON (CHALK-HILL BLUE) AND ELEVEN OTHER BUTTERFLIES 


\section{LIST OF FULL-PAGE PLATES xi}

PLATE

XXXIV. ACHERONTIA ATROPOS, SPHINX CONVOLVULI AND

SEVEN OTHER MOTHS - $\quad$ - $\quad$ - $\quad$ - 168

XXXV. CHEROCAMPA ALECTA, DEILEPHILA VERPERTILLIO

AND FIVE OTHER MOTHS $\quad$ - $\quad$ - $\quad$ - 171

XXXVI. COSSUS LIGNIPERDA, ZEUZERA PYRINA AND FOUR-

TEEN OTHER MOTHS -

XXXVII. PLUSIA CHRYSITIS, HALIAS PRASINANA AND NINE

OTHER MOTHS -

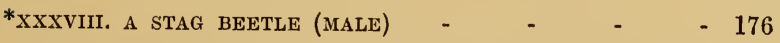

XXXIX. DICRANURA VINULA, LOPHOPTERYX CAMELINA AND

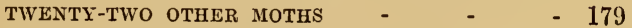

XL. MACROGlossa Stellatarum, MaCROGLOSSA FUCI-

FORMIS AND TWENTY-ONE OTHER MOTHS - $\quad 180$

XLI. UROPTERYX SAMBUCARIA, RUMIA LUTEOLATA AND THIRTY-ONE OTHER MOTHS

*XLII. THE LONG-HANDED BEETLE

*XLIII. heRCULES BEETLE .

*Xliv. head of hercules beetle (MALE)

*xlv. goliath BeEtle

*xLVI. gOLIATH BEETLE

Between 184-185

*xlvii. goliath Beetle

*xLVIII. gIANT tiger BEETLE

*XLIX. FIDDLE BEETLE

L. XYLOPHASIA MONOGLYPHA, DIPTERYGIA SCABRIUSCULA AND TWENTY-FIVE OTHER MOTHS - - 187

LI. MELANTHIA BICOLORATA, HYPSIPETES SORDIDATA AND FORTY-FIVE OTHER MOTHS - $\quad$ - $\quad$ - 188

LII. MANIA MAURA, MANIA TYPICA AND TWENTY-THREE OTHER MOTHS -

LIII. SILPHA THORACICA, SILPHA RUGOSA AND TWENTY

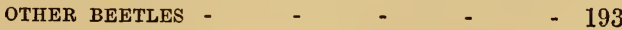

LIV. GNORIMUS NOBILIS, MELOLONTHA VULGARIS AND EIGHTEEN OTHER BEETLES 
PLATE FACING PAGE

LV. AMAURODES PASSERINI, DICRANOCEPHALUS WALLICHI AND FOURTEEN OTHER BEETLES

LVI. A GROUP OF TIGER BEETLES

LVII. DICHIROTRICHUS PUBESCENS, HARPALUS ENEUS AND EIGHTEEN OTHER BEETLES

LVIII. PANAG在US 4-PUSTULATUS, CICINDELA CAMPESTRIS

AND THIRTEEN OTHER BEETLES -

LIX. DYTISCUS PUNCTULATUS (FEMALE), ACILIUS SULCATUS

(FEMALE) AND TWELVE OTHER BEETLES

- 204

LX. PHILONTHUS ANEUS, OCYPUS MORIO AND SEVENTEEN OTHER BEETLES - $\quad$ - $\quad$ - $\quad$ - $\quad 206$

LXI. A GROUP OF CLICK BEETLES - - - $\quad$ - 209

LXII. CYPHOGASTRA JAVANICA, CONOGNATHA PRACTIOSSIS-

SIMA AND FOURTEEN OTHER BEETLES - - 211

LXIII. DONACIA CRASSIPES, DONACIA SEMICUPREA AND

TWENTY-ONE OTHER BEETLES - $\quad$ - $\quad$ - 212

LXIV. ZOPHOBAS SP., ERODIUS ORIENTALIS AND TWENTY -

FOUR OTHER BEETLES - $\quad$ - $\quad$ - $\quad 214$

LXV. MOLURIS GIBBA, GONOPUS TIBIALIS AND NINETEEN

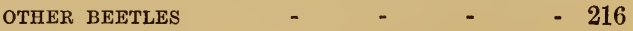

LXVI. LAMPYRIS NOCTILUCA (MALE), TELEPHORUS RUSTICUS

AND THIRTEEN OTHER BEETLES - $\quad$ - $\quad$ - 219

*lxviI. head of Palm WeEvil, greatly ENLARged - 220

LXVIII. ITHOCRITUS RUBER, SPHINGNOTUS MIRABILIS AND

NINE OTHER BEETLES - $\quad$ - $\quad$ - $\quad$ - $\quad$ - 222

${ }^{*}$ LXIX. COCOON OF PALM WEEVIL - $\quad$ - $\quad$ - $\quad$ - 224

LXX. A GROUP OF WEEVILS - - $\quad$ - $\quad$ - $\quad$ - 228

LXXI. A GROUP OF BEES $\quad$ - $\quad$ - $\quad$ - $\quad$ - 236

*LXXII. NEST OF LEAF-CUTTER BEE - _ - - $\quad-248$

LXXIII. A GROUP OF DIPTERA $\quad$ - $\quad$ - $\quad$ - $\quad$ - $\quad$ - 299

LXXIV. BRITISH FLIES - 


\section{INSECT LIFE}

\section{CHAPTER I \\ INTRODUCTION, CLASSIFICATION, AND METAMORPHOSIS}

\section{INTRODUCTION.}

THE entomologist of to-day is a scientist; he bears no manner of semblance to his predecessors, who, longhaired and bespectacled for choice, garbed in apparel of uncommon cut, roamed the countryside in search ofplunder. There is no other word for it; the old time "bug-hunter" was out to kill: he helped to make some of our uncommon insects wellnigh extinct. And the object of his depredations was merely the filling of some tawdry, pendant glass-topped case with specimens arranged in bizarre patterns.

Nowadays these one-time sportsmen are as extinct as the Dodo; they do not exist outside musical comedy, and their musty hotchpotches of specimens have either gone the way of their sponsors or are accumulating dust in forgotten corners of antique shops.

Entomology is slowly but surely coming to the fore; even our most conservative Universities have admitted the subject to their curricula, and, the world over, trained entomologists are gathering knowledge that will 
enable their fellows to combat harmful and destructive insects.

For a reason difficult to explain the sister sciences of botany and entomology are often looked upon as being somewhat effeminate. The idea is fostered in our public schools. The boy who takes up chemistry or physics is, in the eyes of his schoolfellows, except those super-youths who scan their small horizon through glasses of classic mould, merely following a natural, healthy bent. The budding botanist or entomologist is usually a butt for crude sarcasm, or worse.

Let the lover of plants and insects take heart; his hobby may carry him to realms of real utility. Putting aside systematic work for the moment, we are learning more and more each day the immense importance of economic entomology. The medical man knows that many of the most deadly human diseases are carried from patient to patient solely by insects. Despite this knowledge, it is a most astounding fact that there are an almost infinitesimal number of medical men who possess even a, so-called, nodding acquaintance with entomology. Many of the most brilliant discoveries in this branch of the science have been made by laymen.

The fruit-grower knows, or should know, that only by a knowledge of the life-histories of the harmful insects that take toll of his crops is he able to deal with them effectually. The market-gardener and the farmer are in like case. The latter, if he be also a stock-keeper, has a double watch to keep, for there are many insects which bring disease and even death to his cattle.

In the farm, the orchard, the poultry-yard, even in our homes, the ubiquitous insect is waging constant 
warfare against man and his belongings. How, then, can a science which enlightens us concerning the means best fitted for combating the common enemy be other than important? It is hardly necessary to labour the point that, the more we know of our enemies, the more effectually we are enabled to render futile their machinations.

Numerically insects far exceed the combined total of all the other living creatures on this earth of ours. In size they vary from giant stick insects and Moths, measuring several inches in body-length and wing-span respectively, down to minute Beetles, invisible to the naked eye, and much smaller than Cheese-mites, which were once thought to be the smallest creatures. Their lives may be spent almost wholly in the air, in water, and on or in the soil. Many dwell during one period of their lives in one element and in another during the remainder of their existence. There are few substances, natural or man-made, which will not afford a home to some insect species.

In taking up the study of entomology seriously, whether as a hobby or as a profession, one is at once confronted with the problem of selecting which branch of the science to pursue. Maybe systematic work will appeal most strongly, or medical entomology. The student who already possesses a knowledge of botany will probably be attracted to the study of insects destructive to crops. This, however, is a point that need not be laboured beyond the reminder that we live in an age of specialists; and the all-round entomologist is as rare as the quondam " bug-hunter."

Systematists may be called the foundation-stones 
of the entomological edifice; they are the indispensables of the science. It may appear stale and unprofitable to sit, day by day, within the four walls of a museum studying a single order of insects, or, perchance, merely a small group, picking out here and there minute but important details which may or may not be essential to the better ordering of their specimens. From the time of the great Swedish naturalist Linnæus to the present day, the systematists have laboured to the advantage of entomology in general. The medical entomologist must either know something of systematic work or turn, time and again, to the systematist for help; so, perforce, must the student of agricultural entomology and all others who would study the lives of insects; for of what avail is it to know how some six-legged creature spends its days if one remains ignorant of its relationships or even of its identity?

In the pages which follow we have essayed a review of the more salient features of insect life. The text is arranged on strictly scientific lines and with the greatest attention to accuracy, for it is hoped that "Insect Life" may appeal to teachers and students of entomology. We are, however, mindful that many of our fellow-men will only take kindly to a new subject when they feel assured that no attempt is being made to offer them a surfeit of dry-as-dust facts. On that account every endeavour has been made to keep paramount the innate interest of insect life.

No single volume could ever deal with every form of insect life; our pages, perforce, only treat of a relatively small number of types. A knowledge of the structure, relationships, and habits of these typical insects will, 
it is hoped, lead to a closer study of entomology in general, a consummation which will render the writing of "Insect Life" worth while.

\section{Classification.}

Very many years ago, in the middle of the eighteenth century to be exact, Linnæus laid the foundations of modern zoological classification. Seeing that more than a quarter of a million different kinds of insects are known to entomologists, it is evident that their orderly and methodical arrangement is a matter of necessity. It is unfortunate, however, that entomologists are not agreed and apparently cannot agree upon a definite scheme of classification.

As in the case of all animals, insects are arranged in orders, suborders, families, subfamilies, genera, and species. They are placed in these categories according to their apparent relationships with one another, as judged, mainly, by their anatomical structure. Even at the present day there is considerable difference of opinion as to the characters which are of sufficient importance to warrant placing certain insects in the same category. Some authorities recognize but eight orders, others more than a score, and between the two there is ample choice. Before proceeding to a consideration of the reasons for this diversity of opinion, it is as well to be clear concerning the fundamentals of classification.

The placing of insects in various groups is not a mere arrangement for the sake of convenience. Such is our knowledge at the present day that, even with our imperfect and ever-changing schemes of classification, 
they are arranged, or should be arranged, according to their descent. Mere external appearance is no sure guide in making a classification. Various modifications for particular modes of life will often so change the outward aspect of an insect that, judging by externals alone, the most distantly related forms would be grouped together. A study of development and internal anatomy is absolutely essential, and will alone reveal true relationships. In any group, then, whether the members outwardly resemble one another or not, if they are correctly placed, they are all blood relations. Being relations, it is highly probable that they will, for the most part, be somewhat similar to one another, but there are aberrant forms in many groups.

The first step in classification consists in dividing the animal kingdom into branches, and insects are placed in the branch Arthropoda because their bodies are more or less distinctly segmented and their appendages (legs, etc.) are jointed. The branch Arthropoda comprises five classes:

I. Crustacea (Lobsters, Crabs, Shrimps, etc.).

II. Onychophora (Slime Slugs).

III. Myriapoda (Centipedes, etc.).

IV. Insecta (Insects).

V. Arachnida (Scorpions, Spiders, Ticks, etc.).

Of these, Insecta only need be considered. In certain books the class is known as Hexapoda, for the reason that adult insects are always provided with six legsin fact, the number of legs and the division of the body (not always apparent) into head, thorax, and abdomen, distinguishes insects from all other creatures. 
The class Insecta is divided into three subclasses:
A. Apterygota (the members of this subclass never develop wings).
B. Exopterygota (the members of this subclass have wing-rudiments visible throughout growth).
C. Endopterygota (the members of this subclass have hidden wing-rudiments).

The Apterygota are wingless throughout life. There are other so-called wingless insects which do not belong to the subclass, but they possess the rudiments of wings, as careful examination, either external or internal, will show.

The Exopterygota always have their wings, or at least rudiments of wings, visible during their periods of growth. The common Cockroach belongs to this subclass, and the young Cockroach, in common with all other insects similarly classified, emerges from the egg provided with the rudiments of wings.

The Endopterygota includes all those insects which pass through a caterpillar stage. During this stage growth takes place, but no amount of investigation will give any hint of the wings with which the insect is to be provided at a later stage of its development.

The three subclasses are divided into orders, and at this point there is considerable diversity of opinion as to the degree of subdivision which should take place. Linnæus recognized but seven orders; the American practice is to make use of nineteen orders. Carpenter, a noted authority, divides his insects into twenty orders. For convenience sake the orders dealt with in " Insect Life" are tabulated, and a brief description of each 
order follows the table. Three of the orders, Protura, Zoraptera, and Zeugloptera, are merely of academic interest, and are only included to make the scheme of classification complete.

\section{CLASS INSECTA OR HEXAPODA}

Subclass Apterygota

Orders.

Families.

I. Protura.

II. Collembola $\quad$.. (i.) Aphoruridæ, (ii.) Poduridæ, (iii.) Entomobryidæ, (iv.) Papiriidæ, (v.) Smynthuridæ.

III. Zoraptera.

IV. Thysanura.. ‥ (i.) Campodeidæ, (ii.) Japygidæ, (iii.) Lepismatidæ, (iv.) Machilidæ.

SUbClass Exopterygota.

Orders.

Families.

V. Mallophaga

.. (i.) Trichodectidæ, (ii.) Philopteridæ,

VI. Anoplura ..

(iii.) Gyropidæ, (iv.) Liotheidæ

VII. Odonata .

. (i.) Pediculidæ.

.. (i.) Calopterygidæ, (ii.) Agrionidæ, (iii.) Gomphidæ, (iv.) Corduligasteridæ, (v.) Æsschnidæ, (vi.). Cordulidæ, (vii.) Libellulidæ.

VIII. Plecoptera .. _. Perlidæ.

IX. Ephemeroptera .. Ephemeridæ.

X. Isoptera $\quad . \quad \quad$.. Termitidæ.

XI. Orthoptera.. $\quad$.. (i.) Blattidæ, (ii.) Mantidæ, (iii.) Phasmidæ, (iv.) Gryllidæ, (v.) Locustidæ, (vi.) Acridiidæ.

XII. Euplexoptera _. Forficulidæ.

XIII. Embioptera $\quad$. E Embiidæ.

XIV. Psocoptera.. .. (i.) Psocidæ, (ii.) Atropidæ.

XV. Thysanoptera .. Thripidæ.

XVI. Rhynchota. 
Suborder Heteroptera.

Orders.

Families.

(i.) Pentatomidæ, (ii.) Coreidæ, (iii.) Lygæidæ, (iv.) Pyrrhocoridæ, (v.) Tingidæ, (vi.) Aradidæ, (vii.) Hydrometridæ, (viii.) Henicocephalidæ, (ix.) Reduviidæ, (x.) Cimicidæ, (xi.) Capsidæ, (xii.) Nepidæ, (xiii.) Belostomidæ, (xiv.) Notonectidæ, (xv.) Corixidæ.

SUBorder HoMoptera.

Orders.

Families.

(i.) Cicadidæ, (ii) Fulgoridæ, (iii.) Membracidæ, (iv.) Cercopidæ, O (v.) Jassidæ, (vi.) Psyllidæ, (vii.) Aphidæ, (viii.) Aleurodidæ, (ix.) Coccidæ.

Subclass Endopterygota.

Orders.

Families.

XVII. Planipennia

XVIII. Trichoptera

XIX. Zeugloptera.

XX. Lepidoptera. 
Suborder Rhopalocera.

Orders.

Families.

(i.) Nymphalidæ, (ii.) Erycinidæ, (iii.) Danaidæ, (iv.) Satyridæ, (v.) Morphidæ, (vi.) Brassolidæ, (vii.) Heliconiidæ, (viii.) Lycænidæ (ix.) Pieridæ, (x) Papilionidæ, (xi.) Hesperiidæ.

Suborder. Heterocera.

Orders.

Families.

(i.) Castniidæ, (ii.) Saturniidæ, (iii.) Bombycidæ, (iv.) Eupteroptidæ, (v.) Sphingidæ, (vi.) Notodontidæ,(vii.) Cymatophoridæ, (viii.) Sesiidæ, (ix.) Zygænidæ, (x.) Psychidæ, (xi.) Cossidæ, (xii.) Hepialidæ, (xiii.) Drepanidæ, (xiv.) Limacodidæ, (xv.) Lasiocampidæ, (xvi.) Endromidæ, (xvii.) Lymantriidæ, (xviii.) Hypsidæ, (xix.) Arctiidæ, (xx.) Geometridæ, (xxi.) Noctuidæ, (xxii.) Pyralidæ, (xxiii.) Pterophoridæ, (xxiv.) Tortricidæ, (xxv.) Tineidæ.

Suborder Lamellicornia. Orders.

Families.

XXI. Coleoptera.

(i.) Passalidæ, (ii.) Lucanidæ, (iii.) Copridæ, (iv.) Melolonthidæ, (v.) Rutelidæ, (vi.) Dynastidæ, (vii.) Cetoniidæ.

Suborder Adephaga.

Orders.

Families.

(i.) Cicindelidæ, (ii.) Carabidæ, (iii.) Pelobiidæ, (iv.) Dytiscidæ. 
Suborder Polymorpha.

Orders.

(i.) Paussidæ, (ii.) Gyrinidæ, (iii.) Hydrophilidæ, (iv.) Platypsyllidæ, (v.) Leptinidæ, (vi.) Silphidæ, (vii.) Pselaphidæ, (viii.) Staphylinidæ, (ix.) Histeridæ, (x.) Nitidulidæ, (xi.) Trogositidæ (xii.) Cryptophagidæ, (xiii.) Mycetophagidæ, (xiv.) Coccinellidæ, (xv.) Dermestidæ, (xvi.) Byrrhidæ,(xvii.) Bostrychidæ, (xviii.) Ptinidæ, (xix.) Malacodermidæ, (xx.) Cleridæ, (xxi.) Dascillidæ, (xxii.) Elateridæ, (xxiii.) Buprestidæ.

Suborder Heteromera.

Orders.

\section{Families.}

(i.) Tenebrionidæ, (ii.) Cistelidæ, (iii.) Meloidæ.

Suborder Phytophaga.

Orders.

Families.

(i.) Bruchidæ, (ii.) Donacidæ, (iii.) Sagridæ. (iv.) Crioceridæ, (v.) Clythridæ, (vi.) Cryptocephalidæ, (vii.) Eumolpidæ, (viii.) Chrysomelidæ, (ix.) Halticidæ, (x.) Galerucidæ, (xi.) Hispidæ, (xii.) Cassididæ, (xiii.) Prionidæ, (xiv.) Cerambycidæ, (xv.) Lamiidæ.

SUBORDER RHyNChOPHORA.

Orders.

Families.

(i.) Anthribidæ, (ii.) Curculionidæ, (iii.) Scolytidæ, (iv.) Brenthidæ.

XXII. Strepsiptera Stylopidæ.

XXIII. Hymenoptera. 
SUboRder Sessiliventres.

Orders.

Families.

(i.) Tenthredinidæ, (ii.) Siricidæ, (iii.) Cephidæ.

Suborder Pbtiolata.

Orders.

Families.

Series 1. Parasitica: (i.) Ichneumonidæ, (ii.) Brachonidæ, (iii.) Evaniidæ, (iv.) Chalcididæ, (v.) Proctotrypidæ, (vi.) Cynipidæ.

Series 2. Tubulifera: Chrysididæ.

Series 3. Aculeata-Division Anthophila: Apidæ.

Division Diploptera: (i.) Eumenidæ, (ii.) Vespidø.

Division Fossores: (i.) Mutillidæ, (ii.) Thynnidæ, (iii.) Scoliidæ, (iv.) Sapygidæ, (v.) Psammocharidæ, (vi.) Sphegidæ.

Division Heterogyna: Formicidæ.

Orders.

Families.

XXIV. Siphonaptera

Pulicidæ.

XXV. Diptera .. .. Series Orthorrhapha Neurocera :(i.)Cecidomyiidæ, (ii.) Mycetophilidæ, (iii.) Culicidæ, (iv.) Chironomidæ, (v.) Psychodidæ, (vi.) Dixidæ, (vii.) Tipulidæ, (viii.) Bibionidæ, (ix.) Simulidæ.

Series Orthorrhapha Brachycera: (i.) Stratiomyidæ, (ii.) Leptidæ, (iii.) Tabanidæ, (iv.) Scenopinidæ, (v.) Bombyliidæ, (vi.) Asilidæ, (vii.) Empidæ. 
Orders.

Families.

Series Cyclorrhapha Aschiza: (i.) Pipunculidæ, (ii.) Conopidæ, (iii.) Syrphidæ.

Series Cyclorrhapha SchizophoraGroup Calypteratæ: (i.) Estridæ, (ii.) Tachinidæ, (iii.) Sarcophagidæ, (iv.) Muscidæ, (v.) Anthomyiidæ.

Group Acalypteratæ: (i.) Scatophagidæ, (ii.) Sepsidæ, (iii.) Ortalidæ, (iv.) Trypetidæ, (v.) Diopsidæ, (vi.) Oscinidx, (vii.) Drosophilidæ, (viii.) Agromyzidæ.

Series Pupiparia: (i.) Hippoboscidæ, (ii.) Braulidæ, (iii.) Nycteribiidæ.

Formidable as this list may appear, it is by no means complete as far as the families are concerned. To deal, however concisely, with even a few members of all the recognized families would require a volume of enormous dimensions.

The members of the various families are again divided into genera and species, and further division may occur into subgenera, subspecies, or varieties, but we have travelled far enough along the badly metalled road of classification. One or two examples may make matters more clear. The common House-fly is known to entomologists the world over as Musca domestica, L. To assign a high-sounding title to so common an insect may appear to savour of pedantry. A moment's consideration, however, will show that popular names are likely to lead to misunderstanding. The House-fly occurs in practically every part of the world where man 
has taken up his abode, and the insect has a different popular name in every language. How is the Britisher to know that the Typhoid-fly of America and the Housefly of his own country are one and the same insect? Popular names often differ in neighbouring counties, yet Musca domestica is the one title which denotes the common House-fly everywhere. This Fly, then, belongs to the genus Musca and the species domestica. The letter L. which follows its name shows that it was first described by Linnæus.

The name of the author responsible for an insect's title is often omitted, but such omission may cause confusion. For instance, there is a common yellow Humble-bee called Bombus muscorum; there is another, equally common, yellow and black Humble-bee of the same name. The former was described by Kirby and the latter by Smith. Were the author's names appended, the expert entomologist would know to which Humble-bee reference was made. In any case, it is confusing to have two closely related insects bearing similar names. In the examples we have quoted this source of confusion is removed by the fact that the $B$. muscorum of Kirby had been previously described as $B$. venustus by Smith, and the B. muscorum of Smith had been named $B$. agrorum by Fabricius, and the name of the prior author always stands. This is a strict and necessary rule in classification, for, with many workers in the field, it is no uncommon occurrence for a scientist to describe some form which has already been described. No animal can have more than one generic and one specific name, so its first published name is the one by which it is known. 
To return to the House-fly; its place in our classification is made clear by the following brief table:

Branch: Arthropoda.

Class: Insecta.

Subclass: Endopterygota.

Order: Diptera.

Suborder: Cyclorrhapha schizophora.

Genus: Musca.

Species: Domestica.

Metamorphosis AND Growth.

The reader who scans our pages cannot fail to be struck with one outstanding feature-all insects pass through some sort of a change in the course of their complete lives. In a few, a very few, cases the change is very slight; the newly born insect is practically a replica in miniature of its parent, and by increase of size alone it attains the adult stage. In many cases, and they are more familiar, the insect only completes its development by a series of abrupt stages, totally dissimilar to one another. There are also several intermediate forms between the two, and a few exceptional phenomena which do not rightly fit into any class. These changes, of whatever their nature, are known as metamorphosis, and a few typical examples may make the following pages more comprehensible.

Taking the case of the Common Cabbage White Butterfly, Pieris brassica, we have an insect whose life-cycle-the complete round from perfect insect to perfect insect-may be observed without difficulty. After pairing, the female deposits her eggs upon some 
plant which will form the food of the next stage in the life-cycle. The egg is the first stage in the metamorphosis of this insect. In due course the eggs will hatch and caterpillars will emerge. Caterpillars are technically known as larvæ, and they form the second stage. They feed ravenously, for the larval stage is a growing stage. By degrees they grow to such an extent that their skins are in danger of becoming too small. They cease feeding for a short period, their outer skins are shed, and below they are clad in a new and larger skin. Once more feeding commences, and continues till this skin also is too small, and the operation is repeated. The operation of skin-casting is known as moulting, and the number of moults are constant in each species, but variable in different species. Some larvæ moult but twice, others as many as twenty times.

Here we may fittingly attempt to remove a very popular misconception: that adult insects-that is, insects in their last stage-grow. We often hear the remark, "Oh, there is a young House-fly!" as a small Fly is indicated. As a matter of fact, the individual usually described as a small House-fly invariably proves to be another species altogether, the Lesser House-fly, Fannia canicularis. Someone may here remark that in a collection of insects it is possible to find several individuals, which expert entomologists describe as being all of the same species and sex, of varying size. This is true, but is easily accounted for; the amount and quality of food in the larval stage has a very great bearing upon the ultimate size of the perfect insect, but we shall return to this subject on another page. After this digression, let us return to our larva, which 
we will presume is fully fed-that is to say, it has completed its growth and passed through its last moult. The larva becomes restless, seeks a place where it may undergo its next transformation, makes itself secure by means of silken threads, and passes into the resting pupal stage. The pupa is usually inert; it possesses but feeble powers of movement, and in our example never moves from its original position. At any rate this, the third stage, is outwardly a dormant stage. Within the pupal case wonderful changes are taking place, but it is not within our province to deal with them here. When these changes are complete the pupal skin splits and the perfect insect or imago emerges, having completed its life-cycle and possessed of full sexual characters.

A life-cycle of the nature described above, therefore, consists of four stages-(1) The dormant egg, (2) the active growing larva, (3) the dormant pupa, and (4) the active, non-growing imago. Such a metamorphosis is said to be complete and is the rule among Hymenoptera, Lepidoptera, Diptera, Siphonaptera, Coleoptera, Trichoptera, and Planipennia.

The life-cycle of the Cockroach, Blatta orientalis, is quite different. The female deposits her eggs. The eggs give rise to active larvæ, which grow and moult, as do those of the White Butterfly; but whereas the latter larvæ bore no kind of likeness to their parents, the Cockroach larvæ are very similar to the adults, except that they are smaller. By a series of moults they attain nearly the adult stage; at the final moult they are so similar to their parents that it requires an expert to say whether they are adults or nymphs, as 
they are called at this stage. The final moult produces the sexually mature imago.

The metamorphosis of the Cockroach is incomplete; it includes no resting pupal stage.

There are many other forms of incomplete metamorphosis; the transformations of the Dragon-fly may be cited. The egg gives rise to the active larva, quite unlike the parent insect. The larva transforms into the active nymph, which bears considerable resemblance to the imago into which it will develop. Again there is no resting pupal stage.

Incomplete metamorphosis is the rule among Orthoptera, Rhynchota, Odonata, Mallophaga, Euplexoptera, Plecoptera, Isoptera, and Ephemeroptera.

There are some insects, species belonging to the Collembola and Thysanura, which might correctly be described as exhibiting incomplete metamorphosis. As a matter of fact, their transformations are so slight that they hardly deserve the appellation, for the larvæ simply grow to the adult stage by a series of moults.

The time taken for an insect to pass through its lifecycle depends on its species, and, in the same species, depends upon external conditions, such as climate and food-supply.

The Seventeen Year Old Locust (p. 119) requires seventeen years to pass through its life-cycle; many Aphidae complete their cycle in a week. Again, certain species which in this country have two broods a year-i.e., pass through a complete life-cycle twice in twelve monthsperform the same operation three times in a similar period in a warmer climate. The Ant Lion may undergo its metamorphosis rapidly when food is plentiful; 
should the larva be starved, however, the larval stage, and hence the life-cycle, is much protracted.

There are many species of insects which contrive to shorten the period of their transformations, or, more correctly, their transformations are habitually shortened. The Sheep Bot-fly, Estrus ovis, deposits young living larvæ, thus missing the egg-stage; the same phenomenon is common amongst the Sarcophaga, or Flesh-flies. Still more time is saved by the Tsetse-flies, Glossina, whose larvæ at birth are almost fully grown and ready to pupate. The Pupiparia were so named because they were supposed to give birth to pupæ; as a matter of fact, their larvæ at birth are in such an advanced stage of development that they pupate immediately.

All insects producing living young are said to be viviparous. The common Aphides afford striking and easily observed examples of viviparous insects; in them also may be studied the phenomenon of parthenogenesis -i.e., reproduction without pairing. This phenomenon, rare amongst the Animal Kingdom in general, is fairly common amongst insects.

Paired female Aphides lay hard, black, winter eggs on shrubs, etc., likely to provide food for their young. In the spring the eggs hatch, and after a series of moults the young grow into wingless females. These wingless females, unaided by males-indeed, there are none early in the year-produce brood after brood of living wingless females similar to themselves. Later in the year winged females are born, and they migrate to other plants, and so spread the race far and wide. Towards autumn both winged males and females arrive on the scene; they pair and as a result the winter eggs are pro- 
duced. It is evident that this parthenogenetic mode of reproduction is a great time-saver.

A still more remarkable variant of the normal lifecycle occurs amongst certain Cecidomyiida of the genera Miastor and Oligarces. The females lay one or two exceptionally large eggs, from which, in due course, a larva emerges. This larva, however, is no ordinary individual, for within its body other larvæ developother larvæ of the same species. The phenomenon must not be confused with any kind of parasitism, where larvæ of another species or genus or order may develop from the body of some luckless larva. These larvæ devour the interior of the parent larva, pierce its empty skin, and come into the world as ordinary larvæ. In exceptional cases these larvæ too may give birth to other individuals, and so on for several generations. The final generation of larvæ behaves in the ordinary manner, pupates, and gives rise to the adult Fly. A phenomenon of this nature is known to scientists as pædogenesis.

Of all these time-saving devices designed by Nature, evidently with the object of bringing a large insect population into the world rapidly, nothing is more extraordinary than the story of the Termitoxeniida. These wingless insects are allied to the Pupiparia; they dwell in Termites' nests, and they are hermaphroditethat is to say, there are no separate males and females, but each individual possesses the characters of both sexes. These strange creatures lay large eggs, whence arise, in nearly every case, fully developed adults.

There are a considerable number of insect life-cycles which cannot be completed without the assistance of 
some other, probably non-related insect. Under this heading, of course, must be included all cases of parasitism; many of these are referred to in the following pages. One of the most curious of these histories is that of certain Blister Beetles, Meloidce, and to the phenomenon the name of hypermetamorphosis has been given. To Fabre we are indebted for the life-story of Sitaris humeralis, a Blister Beetle which in its immature stages is dependent upon Bees of the genus Anthophora.

The Beetle deposits its eggs, to the number of about two thousand, near the Bee's nest; this occurs in the summer. Towards autumn small black larvæ, called triungulins, because they have three claws on their tarsi, emerge from the eggs. These larvæ hibernate where they are hatched, and do not feed at all. In the spring they awake to activity, and their one object is to become attached to the hairy body of the Bee, at the door of whose nest they are waiting.

Now, these larvæ have no powers of discriminating between the hairy body of the Bee and any similar object; as a consequence many of them are carried away on other objects, maybe the body of a mouse, and never reach the haven where they would be. It is fortunate that the mother Beetle is so prolific, for many of its larvæ never attain maturity. It is a general rule in the Animal Kingdom that in the species whose progeny normally undergo many risks, great fecundity is shown.

Let us follow the fortunes of a successful triungulin. It becomes attached to the body of a female Anthophora, who, if the larva be fortunate, has stored her honey in her brood-cell and is about to lay her single egg therein. As the Bee lays her egg, so the larva releases its hold of 
her hair, and floats upon the egg as upon a raft. The Bee closes the cell, and the triungulin is left in sole possession of the egg and a store of honey. The larva makes its first meal of the egg, and occupies about a week in the devouring of it; all this time it remains floating on the shell, for immersion in the honey would be fatal. On the remnants of the egg-shell the larva moults, and appears as a totally different creature, able to float on the honey. For about six weeks it lives in the honey, which it consumes the while; at the end of this time, having devoured all the stores which the cell contained, the insect changes into a pupa within the larval skin, and either emerges as a perfect insect in about a month or delays the advent for a longer period.

Hypermetamorphosis is common amongst the Meloido; our common Oil Beetle, Meloe proscaraboeus, has a very similar life-story to the one just described. It also depends upon Anthophora for the upbringing of its larvæ, but it does not deposit its eggs near that insect's nest. The risk of misadventure, therefore, is far greater than in Sitaris; as a consequence the female Melce is still more prolific, ten thousand eggs being no unusual number for a single female to lay.

An American Blister Beetle, Epicauta vittata, has a very similar life-story; the unwilling foster-parents, if we may use such a term, of its larvæ are Locusts of the genus Caloptenus. In one important particular Epicauta differs from both Sitaris and Melce; its triungulins are active. Their early life is spent in the egg-cases of the Locust, and the young triungulins hunt hither and thither for the object that is to form their home. Nothing is left to chance; if a Caloptenus has oviposited 
near the Beetle larvæ, they will discover the eggs. As the risk of failure is diminished, so we find that Epicauta is not so prolific as the other Blister Beetles.

It must strike the entomologist as strange that female insects, who have no opportunity of learning by experience, always lay their eggs either on the food-plant of their larvæ or near it. This habit led to some interesting experiments quite recently to determine, if possible, by what means the mother insect was guided in her choice. Extracts were made from various plants, and pieces of fabric were soaked with thesubstances extracted. It was found that insects in the habit of ovipositing on, say, Cruciferous plants would oviposit on fabric soaked with the extract of those plants. The experiments were interesting because they showed, at least, how insects are guided to certain plants for purposes of egg-laying. They did not show, however-and the phenomenon still remains to be demonstrated-how the insects know which plants will form suitable food material for their larvæ.

The larvæ of many species, it is true, are not always confined to one species of plant for their food. Some larvæ are fairly catholic in their tastes, but there are species whose needs are satisfied by one kind of plant alone. Of these latter insects none are more remarkable than the Yucca Moths, Pronuba yuccasella. These Tineid Moths can only obtain their food from the yuccaflower, their larvæ can only live on the yucca-plant, and the plant can only become fertilized with the assistance of this one species of Moth. The female is provided with a peculiar sickle-shaped process on her maxillary palps, whose use we shall see in a moment. 
After pairing, the Moth flies to a yucca-flower, collects pollen from its anthers by means of her sickle-shaped process, and rolls it into a ball. Next she visits another flower, and by the aid of her long, pointed ovipositor she lays an egg amongst the ovules within; at the same time she places the ball of pollen in a hollow at the apex of the stigma. The pollen fertilizes the ovules, and the seeds, to the number of about two hundred, begin to develop. When the larva emerges, it feeds upon the ripening seeds; its larval period, however, is of short duration, and after devouring about twenty seeds pupation takes place, and the rest of the seeds develop for the benefit of the yucca-plant.

"The whole proceeding is of great interest ... giving us an example of two species absolutely dependent upon each other for their continued existence. If the Moth had not the structure to form the pollen-ball and the instinct to put it on the stigma, the ovules would not be fertilized and her offspring would have no food; and if the plant was not prepared to sacrifice some ten per cent. of its brood, the rest would never develop at all."

Such a larva as that of the Yucca Moth could not exist in any other situation but in the ovary of the yucca-plant. Startling as its life-story may appear, a moment's consideration will show that all larvæ are beautifully adapted for their particular mode of life. Dozens of examples are to be found in our pages, thousands more can be studied in the world around us, with little effort. The Rat-tailed Maggot, whose appetite must be appeased with decaying vegetable matter from the bottom of some pond, yet whose 
PLATE II

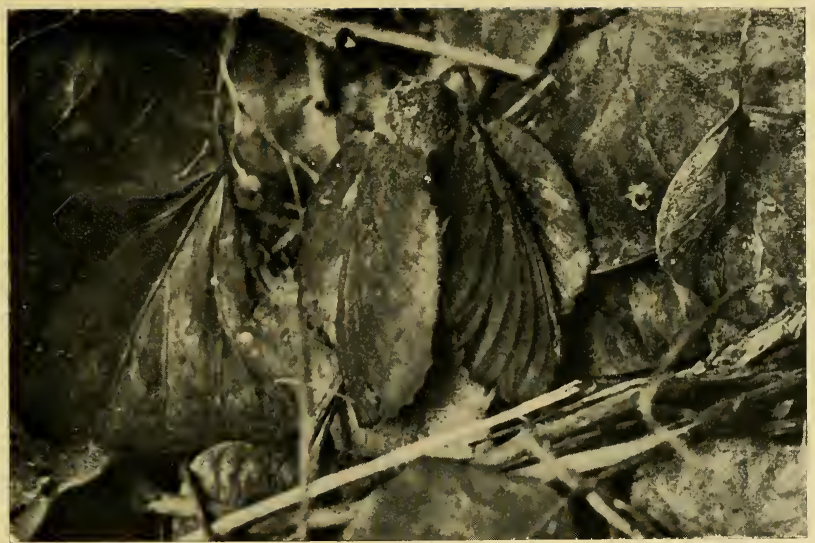

LAPPET MOTH AT REST AMONG DEAD LEAVES

An example of protecive colouring

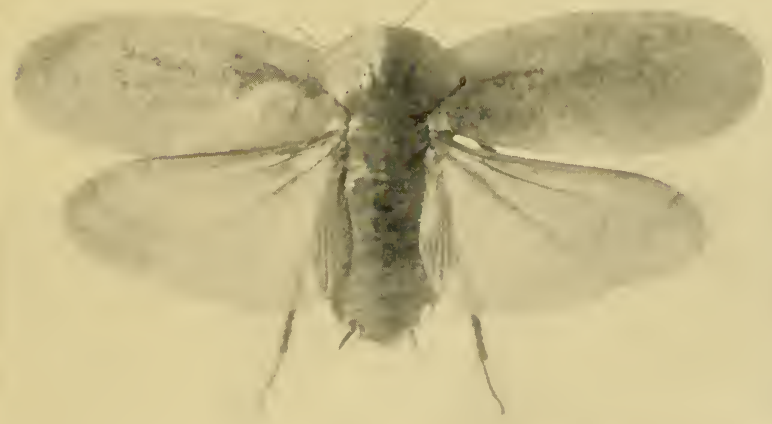



respiratory apparatus needs air, is marvellously contrived to perambulate his muddy home the while he breathes pure air. The Caddis-fly larva, so delicate that he would be an easy prey for predatory creatures which frequent his stream, must perforce build for himself the coat of armour which Nature has omitted to supply. The Vapourer Moth larva, whose mother, being wingless, has little chance of distributing her progeny over a wide area, has such nomadic habits that he, in part at least, makes up for his parent's deficiency. But there is no need to quote more; a moment's thought will show that insect larvæ are given every chance to succeed in the world; some do so better than others, and they are the species that are best adapted for their particular mode of life.

In addition to what may be termed the normal lifecycles, and to the exceptions mentioned on the foregoing pages, there is another form which is worthy of mention. This form of life-cycle, termed " alternation of generations," is particularly prevalent among the Gall-flies, Cynipidoc. Let us take the common spangle gall of the oak as our example. On the under-sides of oak-leaves, towards autumn, we can very often find little reddish plates, thicker in the centre than at the edges; these are the spangle galls of the Gall-fly Neuroterus lenticularis. With the leaf fall the spangle galls come to the ground, and as the leaves decay they become separated. In spring female Flies emerge from the galls; they are able to reproduce their kind parthenogenetically, and they do so by depositing their eggs in the young leaves and leaf-buds of the oak. The result of their efforts is the formation of the so-called currant galls, also well known, 
which closely simulate red currants. From these galls emerge males and females of the Gall-fly Spathogaster baccarum. After pairing, the females lay their eggs in the young oak-leaves, and another colony of spangle galls arises.

The familiar oak-apple is another gall formed by a Cynipid with alternating generations; its winter form makes root galls on the same tree, and the insects in their subterranean home are efficiently protected against inclement weather. This question of hibernation is interesting, and the reader who studies the life-histories given in our pages will soon realize that the winter may be passed in almost any stage. Even with such delicate, or apparently delicate, insects as the Butterflies and Moths, it is easy to select species which winter respectively in the egg, larval, pupal, and imago stage. Whatever the stage, it is always well adapted to withstand severe weather. Either the eggs have tough, hard shells; or the larvæ live underground or in burrows in trees, etc.; or the pupæ are well protected by tough pupal-cases or warm silken cocoons; or, should the imago itself hibernate, it is either an insect little affected by a fall in temperature, or it so contrives to hide itself that it is well protected from the elements.

The weather, however, has a marked influence upon insect life. The least observant among us cannot fail to have noticed that the pulse of the insect world quickens during the warm summer months. Insect life is considerably influenced by its surroundings. Entomologists have shown that certain Lepidoptera, not long since considered to be different species, are in reality wet and dry season forms of the same species, the appearance 
of the adults having been " modified by the climatic environment of the pupa."

Even our native Lepidoptera show this seasonal dimorphism, as it is called, to a lesser degree, the spring brood differing "slightly but constantly from their summer offspring." Take the case of any of our Garden Whites. The wings of the females especially are marked with black spots. In the spring these spots are grey or are much reduced, but in the later summer brood the spots are much darker-coloured and the wings are yellowish instead of pure white.

Again, Pieris rapce is really the summer form of Pieris napi, the Green-veined White; in the spring the greenish veins from which the Butterfly derives its name are broader and more distinct than in the summer form.

"The two forms of this insect were discussed by A. Weismann in his classical work on 'The Seasonal Dimorphism of Butterflies.' He tried the effect of artificially induced cold conditions on the summer pupæ of $P$. napi, and by keeping a batch for three months at the tempera ture of freezing water he succeeded in completely changing every individual of the summer generation into the winter form. The reverse of this experiment also was attempted by Weismann. He took a female of bryonice, an Alpine and Arctic variety of $P$. napi, showing in an intensive degree the characters of the spring brood. The female laid eggs, the caterpillars from which fed and pupated. The pupæ, although kept through the summer in a hothouse, all produced typical bryonice, and none of these, with one exception, appeared until the next year; for in the Alpine and Arctic regions this species is only single-brooded" 
Similar experiments were performed with Araschnia levana, whose summer, more brightly coloured, form is known as $A$. prorsa. After refrigerating the summer pupæ, most of the insects appeared as the winter form, but the converse experiment of warming the winter pupæ failed to convert levana into prorsa. "Weismann argued from these experiments that the winter form of these seasonably dimorphic species is in all cases the older, and that the Butterflies developing within the summer pupæ can be made to revert to the ancestral condition by repeating the low-temperature stimulus which always prevailed during the geologically recent Ice Age." 
SOCIAL HABITS, COLOURING OF INSECTS, AND ECONOMIC QUESTIONS

Social Habits and Guests.

THE majority of insects are solitary in their habits; each individual, or at most a pair of individuals, lives its life irrespective of the activities of others of its kind. Some few are gregarious, the larvæ of Processionary Moths and of many Sawflies, Aphis, and Psocid adults. The number of social insects can be counted on the fingers of one hand: they are Bees, Wasps, Termites, and Ants; and of these, none have carried the social habit to so high a state as the Ants.

These insects are practically ubiquitous; from pole to pole, from the summits of the highest mountains to sea-level, they may be found. Compared with other social insects, their colonies are both more populous and more stable; worker Ants have been known to live for seven years, and queens more than twice as long. Of the other social insects, Bee and Wasp colonies " are merely annual growths," whilst Termites are practically confined to the tropics.

"Ants have either never acquired, or have completely abandoned, certain habits which must seriously handicap " the Termites, Social Wasps, and Bees in their struggle for existence. The Ants neither restrict their diet, like 
the Termites, to comparatively innutritious substances such as cellulose, nor, like the Bees, to a very few substances like the honey and pollen of evanescent flowers, nor do they build elaborate combs of expensive materials such as wax. Even paper as a building material has been very generally outgrown and abandoned by the Ants. Waxen and paper cells are not easily altered or repaired, and insects that are wedded to this kind of architecture not only have to expend much time and energy in collecting and working up their building materials, but they are unable to move themselves or their brood to other localities when the nest is disturbed, when the moisture or temperature become unfavourable, or when the food-supply fails."

Ants, again, have few enemies; true, they are the hosts of various guests, of which more anon, but of deadly foes they have few. Forel, the great authority on these insects, said: "The Ant's most dangerous enemies are other Ants, just as man's most dangerous enemies are other men."

Before considering the social habits of Ants, it will be well to devote some space to one of the most striking peculiarities of these insects-their polymorphism. Strictly speaking, polymorphism means many shapes, and, equally strictly speaking, all animals exhibit polymorphism, for no two organisms are precisely alike in every particular. As used here, however, the term is " merely a synonym of variation," and in its restricted sense is only to be observed amongst social animals, "where its existence is commonly attributed to a physiological division of labour." Wheeler enumerates no less than twenty-seven polymorphic forms of Ants; 
needless to say, these forms never all occur in one colony, nor are they to be found in any one species. It is quite common, however, to find five polymorphic forms, more usually called "castes," in one Ant community; they are winged males and winged females, major and minor workers, females so named on account of their size, and soldiers-workers specially adapted to undertake any fighting that may be necessary. Another interesting "caste," only found in a limited number of species, is known as "nasuti." The function of the nasuti, or nosed ones, is to build the nests and repair them when damaged.

In describing the typical Ant colony, it must always be borne in mind that the habits of Ants vary tremendously-in fact, no two species have precisely similar habits. Our description, therefore, is one of generalities, and applies only to the ground-nesting species.

In colonies where there are winged males and females pairing, with rare exceptions, takes place in the air during a nuptial flight. This is always a period of the greatest excitement; even the wingless workers come to the surface along with the winged males and females. "The winged forms move about in tremulous indecision, but finally venture forth, run about on the stones or climb about on the grass-blades till they have filled their tracheæ with a plentiful supply of oxygen. Then they spread their wings, and are soon lost to view high in the air."

Although the performance is comparable to the swarming of Bees, there are several important differences. In a Bee-swarm there is only a single female, here there are many; the female Ant rarely returns to the colony 
in which she was born; in both cases, however, the males die down after pairing.

When the earth is reached once more, the fertilized queen detaches her wings by rubbing them against grassblades or stones, by pulling them off with her legs, or even biting them off. Having divested herself of wings, which henceforth would be useless to her, she makes a short burrow which terminates in a chamber; then she closes the mouth of the burrow. "The labour of excavating often wears away all her mandibular teeth, rubs the hairs from her body, and mars her burnished or sculptured armour, thus producing a number of mutilations, which though occurring generation after generation in species that nest in hard, stony soil, are, of course, never inherited."

In the chamber she has made, the queen awaits the maturation of the eggs, which takes place at the expense of her fat body and degenerating wing-muscles. She may have to wait months before they are ready to be laid, but eventually she oviposits, her eggs being fertilized by spermatozoa stored in her spermatheca since the nuptial flight. The eggs are tended by the queen till they hatch as minute larvæ; then she feeds them with a secretion of her salivary glands, derived from the same source as the eggs themselves-from her fat body and wing-muscles. These larvæ differ from those hatched later, they grow very slowly, pupate before their time, and give rise to very small workers. "In some species it takes fully ten months to bring such a brood of minim workers to maturity, and during all this time the queen takes no nourishment, but merely draws on her reserve tissues." 
These small workers do not belie their name: they soon "get busy "; they break down the entrance to the nest; they build other chambers and galleries; they sally forth to hunt for food for themselves and the exhausted queen. She in her turn changes her nature from this point; she no longer takes any interest in her progeny, but leaves them to the care of the workers, and limits " herself to the laying of eggs and imbibing liquid food from the tongues of her attendants. . . . With this circumscribed activity she lives on, sometimes to an age of fifteen years, as a mere egg-laying machine."

The later broods of larvæ, as we have said, are tended by the early workers, but when the colony is in going order each worker has her appointed duties to perform. Some act as nurses; they feed and clean the young; they also transport them from one part of the nest to another according to the varying humidity and temperature of the different galleries. Also, in the event of the nest being broken open or of an attack by some other species, the workers remove the eggs, larvæ, and pupæ to a place of safety. "This freedom in dealing with the brood is certainly one of the most striking manifestations of the plasticity of Ants."

It is very unusual for the immature Ants to be brought into the light; apart from other considerations, workers always remove the brood to the dark recesses of the nest when an accident befalls it. Wheeler, however, says that in the dry deserts of Western Texas, he has seen Ishnomyrmex cockerelli bring its larvæ and pupæ out on to the large crater of the nest about 9 p.m., and carry them leisurely to and fro much as human nurses wheel their charges about the city parks in the cool of the evening. 
The workers carry out their duties solely by their highly developed tactile and olfactory senses. The brood, eggs, larvæ, and pupæ are arranged in groups according to their age and condition. During the warmer hours of the day the brood is brought nearer to the surface of the soil; at night it is removed to the deeper recesses of the nest. As Ants' eggs are very minute, it is hardly surprising to learn that they are not carried about separately; the workers constantly lick the eggs, and this causes them to adhere together in little packets; their saliva may have a further use in preventing the growth of moulds.

The larvæ are very soft and white, almost transparent -in fact, in shape they resemble a "crook-necked" gourd, the curved end terminating in the head; of eyes and legs they have none, but they are usually hairy. The hairs probably serve a number of ends; they prevent the delicate skin of the larva from coming in contact with the moist soil; they are a protection against assault by other larvæ, and they hold their owners together in packets and thus assist transport by the workers.

The feeding of the larvæ is carried out by the workers, and according to many authorities " the quantity or quality of the food, or both, determines whether the larva hatching from a fertilized egg shall become a worker or a female." The food supplied to the larvæ varies according to the species; many species feed their larvæ solely upon regurgitated food; some feed them upon solid food, portions of insects, or in the case of the Harvesting Ants, portions of seeds and the Fungusgrowing Ants on fungus hyphæ; some species, again, feed their larvæ on both solid and regurgitated food. 
Many Ant larvæ pupate without spinning any cocoon; other species, however, spin silken cocoons, but they are unable to do so without assistance from the workers. The larvæ can only perform the operation if they are buried in the earth or covered by soil, that there may be a solid foundation to which they can attach their silk. The workers, therefore, bury their charges, await the spinning of the cocoons, and unearth them again. These cocoons, by the way, are the commodity usually sold as ants' eggs for the purpose of feeding fish, cage birds, etc. When the time arrives for the adult to emerge, the workers once more lend their aid; they cut open part of the lower surface of the cocoon, draw out the contained insect, and strip the inner skin from its body, antennæ, and legs. At first the adult Ant is pale in colour, and is known as a "Callow."

Briefly, this is the history of a typical Ant colony. Wheeler, in his work on Ants, whence much of our information is derived, gives an excellent account of the doings of these interesting insects, with details of the peculiarities of different species which depart from the normal.

Symbiosis among insects is nowhere better illustrated than by certain social species, and the Ants have raised the practice of living with other species-for that is what symbiosis means-to a very high standard. For purposes of convenience, at any rate, the symbiosis of Ants may be considered from two points of view. First there are those cases in which Ants, of their own accord, gather together a varied assortment of insects, Green-fly, Scale-insects, Plant-lice, and the like-insects upon which the Ants are almost parasitic. Then there are 
insects which, without encouragement from their hosts, settle themselves to life within an Ants' nest. Insects of the first category all excrete honey-dew, a sweet liquid which is eagerly devoured by Ants; in return, the Ants perform certain services for their captives, so that this is more nearly true symbiosis than is the case with the insects in the second category, who, in many cases, do not benefit or may even harm their captors.

On a later page we have mentioned briefly the relationship of Ants to Aphides. A few more details may fittingly be included here. It perhaps occasions some surprise that any Ants should trouble with insects so small as Aphides, whose yield of honey-dew, one would think, could not be excessive; but recent investigations show that a Maple Aphis will secrete forty-eight drops of the liquid in twenty-four hours. "A drove of Aphids, especially when it is stationed on young and succulent leaves or twigs, may produce enough honeydew to feed a whole colony of Ants for a considerable period. Huber has observed the method by which the Ants procure their honey-dew from the Aphids; we have not space to quote his words, but the usual proceeding is for the Ant to stroke the abdomen of the Aphis with its antennæ, and the latter voids the sugary liquid. When the Ants neglect their charges, the latter void their excretion on to the plant without any assistance; should the Ants, however, become too pressing in their attentions, the Aphids become exhausted and can yield no more nutriment; but the Aphids are by no means parsimonious, and if they have anything to give, never fail to respond to the Ants' solicitations.

With regard to the excretion of honey-dew very many 
erroneous statements have been made, and some of them have found their way into scientific literature. On the sides of the sixth abdominal segment of many Aphids there is a pair of protuberances, called " siphons." Linnæus stated, and others have copied his statement, that the Ants derive their honey-dew from the siphons; the liquid, however, is the excrement of the insects, and does not come from the siphons.

Büsgen, in describing the attack of a Lacewing larva on an Aphis, pointed out the use of the siphons to their owners. "When the attack," he says, " happens to be rather awkward, the Aphid has time to smear the secretion, which is at once discharged from the siphons, over the face and forceps of the larva, which is thus, at least temporarily, disconcerted and frightened.... The secretion hardens on the larva immediately, and thus forms a most uncomfortable coating, causing the creature to desist from the chase while it cleanses its forceps and forehead. This consumes time, and can only be accomplished by the Aphis-lions seizing some slender object, like the tooth of a leaf, for the purpose of rubbing off the secretion." Another authority has shown that the siphons are more highly developed amongst those Aphids that live singly and not in droves, and are not attended by Ants; in such circumstances there is more risk of attack.

The relations of Ants to Coccidoe are very similar to their relations to Aphidce. The Psyllidoe, which void both solid and liquid honey-dew, are closely attended by Ants, and in some cases are protected under sheds built by these insects. Wheeler sums up the relationship with Ants and Aphids very concisely. On the part of 
the Aphids, he says that they do not attempt to escape from or defend themselves against the Ants; they yield their honey-dew gradually, and some species, habitually dwelling with Ants, have developed a circlet of hairs to support the sweet drops till they can be imbibed by the Ants. Aphids attended by Ants extract more plantjuices than unattended individuals, and the reduction of the protective siphons is usually more marked in those species which are visited by Ants. Ants, on their part, never kill Aphids as they do other defenceless insects; they stroke their charges in a particular manner to make them yield their liquid store; they protect their charges, and even carry them to a place of safety when danger threatens; also, not only the adults, but even their progeny, eggs, and larvæ, are cared for by the Ants. More remarkable than any of the cases just described is the fact that Ants are known to attend the larvæ of no less than sixty-five species of Lyccenidae, or " Blues," representing twenty-nine genera. Twenty-three of these species belong to Lyccena. These larvæ, as all Lepidopterists know, are rounded at their head and tail ends, somewhat depressed, and clothed with fine hairs. In the case of Lyccena boetica, there is a median dorsal gland on the eleventh segment, and a pair of protrusile tentacles on the twelfth. The median gland can be protruded through a transverse slit, and the tips of the tentacles are fringed with stiff hairs. The Ants caress the flattened posterior of the larva and a drop of colourless liquid is given off by the median gland; this is evidently relished by the larva's attendants. The tentacles probably give off an odour which is attractive to the Ants, but this has never been shown of a certainty. 
There are a few other insects to which Ants pay more or less assiduous attention; but we have briefly outlined the more important. In every case the insects upon which so much care is lavished are those which have the power of yielding some sugary liquid, in return for the attention bestowed upon them.

It has been truly said that " Ants have such a plastic organization that they are not only able to assume an active rôle towards the Aphids and a passive rôle towards the Myrmecophiles, or Ant guests, but they may even enter into manifold active and passive symbiotic relations to other species of Ants." Their relations with Aphids have been considered; those with other insects may here have some attention. That the subject can only be dealt with cursorily here is evident from the fact that there are known to be at least fifteen hundred species of Myrmecophilous insects, one thousand of them being Beetles. The Coleoptera mainly belong to the Staphylinida, Pselaphidee, Paussida, and Histeridoe. Wheeler supposed that this extraordinary number of Ant guests arises from the fact that their hosts' nests are usually permanent abodes, at a higher temperature than the surrounding soil; that there is plenty of refuse food and fresh fare in the shape of larvæ and pupæ; that the Ants protect their guests in protecting themselves; and that they are always ready to lavish their affections upon any insects that resemble their larvæ.

Many of the guests closely resemble their hosts; by so doing they probably avoid the fate that should justly befall them. The Black Rove Beetle, Myrmedonia funesta, is of the same colour as its host Lasius fuliginosus; the black and red $M$. humeralis simulates 
Formica rufa, with which it dwells. These Beetles live on dead or dying Ants, and lurk near the entrance to the nest to destroy solitary individuals coming in or going out. Five or six Beetles will fall upon a single Ant, " tear her limb from limb, and then quarrel with one another over the fragments, like a pack of hungry hounds. The Ants detest these jackals, and rush at them with open jaws; but the latter merely turn up their flexible tails and emit a disagreeable secretion."

Certain Ant guest Beetles of the genus Clythra only dwell with their hosts in the larval stage, but they are cunning individuals. They build cases in which to dwell, and then, when they are hungry, withdraw their heads within the case. The worker Ants, ever watchful for convenient hiding-places in which to store their eggpackets, deposit them within an apparently empty case. The Clythra larva wastes no time in devouring the meal so obligingly placed before it.

Few Ant guests are more crafty than a little Lepismid Atelura formicaria. This creature is very similar to its near ally the Silver Fish; it does not seem to be a welcome guest, for the Ants often make attacks upon it, but, being exceedingly agile, it rarely comes to any harm. In our chapter on Ants we have mentioned the common practice of one Ant feeding another by passing regurgitated food from mouth to mouth. This is Atelura's opportunity for appeasing its hunger; when two Ants are face to face and about to pass the sugary liquid, their guest glides up with astonishing rapidity, steals the drop as it passes, and makes off.

Certain wingless Crickets of the genus Myrmecophila live on the oily secretions from the bodies of their hosts. 
The Cricket nibbles the legs of the Ant and seems to delight in so doing. "At first the Ant disregards this nibbling, which probably resembles the attentions of the toilet habitually received from sister Ants; but the Cricket's scraping mandibles soon grow to be annoying, and the Ant either moves away or turns her head, opens her mandibles, and makes a lunge at the Myrmecophila, like a large dog annoyed by a puppy. . . . For obvious reasons, the Cricket avoids nibbling at or even approaching the Ant's head. It is always alert, as if perpetually aware of danger, and ready to dodge at the slightest movement of the Ant."

The Crickets may also be observed nibbling at the walls of the nests; probally they derive therefrom some greasy matter rubbed from the bodies of passing Ants. Certain minute Cockroaches, of the genus Attaphila, dwell in the nests of fungus-growing Ants, and, in habit, closely resemble Myrmecophila. They, however, live on friendly terms with their hosts and climb upon their heads and backs in search of nutriment, an event rendered the more strange because they are the only insects known to live on intimate terms with these Ants.

Of the true Ant guests, as distinguished from the tolerated or persecuted guests already mentioned, we have little space with which to deal. They are Beetles for the most part; in colour they are usually red, and they frequently bear tufts of yellow or. red hairs, which are licked by the Ants with evident delight. Wasmann believes that the Ants are so fond of the secretion from these hairs "that it must affect them very much as a good cigar affects a smoker."

Many of the guests are moved from place to place in 
the nest by their hosts, usually by pulling at their legs or antennæ, fed with regurgitated food, licked and fondled as though they were blood relations of the members of the colony. The Staphylinids of the genus Atemeles and Lomechusa are especially favoured, for not only are the adults carefully tended, but their larvæ are treated in every respect with the same attention as their hosts' larvæ.

Concerning the true parasites, whose energies are devoted to thinning the ranks of the Ant colonies, we have no space to deal with them; nor can we describe in these pages any of the many Ant species which dwell together in perfect harmony and to their mutual advantage. Perhaps it is natural, but we are conscious of the fact that these insects have already absorbed more than their duly allotted space in our pages.

\section{The Colours of Insects and Mimicry.}

It is not necessary to have studied entomology very deeply to be aware of the fact that the colours of insects, in the majority of cases, harmonize so nicely with their owner's usual surroundings as to render him more or less inconspicuous, or, on the contrary, are so brilliant that he forces himself upon one's attention. Both descriptions of colouring have their uses in the insect economy; let us consider them in their order.

Colours which harmonize with an insect's environment are usually designed for purposes of concealment; they render their owner inconspicuous, and on this account they are called " protective." In many cases protective resemblance is a better term than protective colouring, 
for often there is a similarity of form as well as colour between the insect and its surroundings.

No better examples of protective resemblance can be found in the insect world than is exhibited by the Leaf Butterflies of the genus Kallima; when at rest, these insects are almost indistinguishable from the surrounding leaves. Certain of our native Lepidoptera exhibit protective resemblance in a minor degree. The Green Hairstreak, Thecla rubi, is dingy brown on its upper surface, but when it settles on green herbage, with its wings folded, its emerald lower surface efficiently matches the verdure. To the tropics, however, we must turn once more for really striking examples. The female Leaf Insect, Phyllium crurifolium, is almost as perfect in its protective resemblance as the Leaf Butterfly, but whereas the latter simulates a dead leaf, the former has the colour and form of a green leaf. These insects (described on p. 90) have been known to bite pieces from the tegmina of their sisters; can they themselves be deceived? It is remarkable, at any rate, that their attacks upon one another are always confined to the leaf-like portions of their bodies. Of the Stick insects and the Geometrid larvæ, which resemble twigs, we have spoken elsewhere.

Bastin, in his book "Insects," describes an interesting case of protective resemblance observed by Professor Gregory in the Great Rift Valley. He says: "The insect in question is a species of Flatc-a genus comprised in the family Fulgoridce. It is found in British East Africa, and is dimorphic, a certain number of individuals being bright pink in colour, while others are bright green. The insects frequent the stems of 
plants, from which they suck the sap; and the order of their grouping is very remarkable. The pink ones sit upon the lower part of the stem, while the green ones take up positions above, towards the extremity. Moreover, the developing larvæ-which secrete long waxy filaments, and are quaint, fluffy objects quite unlike their parents-sit beneath the pink individuals at the lowest part of the stem. In this way the exact appearance of a spiked inflorescence, such as that of the foxglove, is produced. The fluffy larvæ look like seeds; the pink individuals resemble drooping flowers; while the green ones, higher up the stem, play the part of so many unopened buds. Professor Gregory was completely deceived by the first cluster he saw, and attempted to gather it, when the mock flowers and buds jumped off in all directions."

Other examples of protective resemblance are easily discovered. There are Beetles that resemble tufts of lichen and those that resemble larval excrement, to mention but two from one order.

Protective colouring, as distinct from resemblance, is far more common, and there are examples on every side. The green larva feeding on a green leaf is so coloured, but there are more subtle forms than this. Amongst the Lepidoptera we have the larvæ of the Pine Beauty Moth, Panolis piniperda. Away from their food-plant, the pine, they are striking-looking green insects with two dorsi-lateral white lines; when feeding on the pine needles, they harmonize so admirably with their surroundings that they are difficult for bird or man to discover. Another green-striped white larva, that of the Privet Hawk Moth, Sphinx ligustri, is even more 
conspicuous when viewed in the hand, but, large though it is when fully fed, it harmonizes well with its food-plant, the privet.

Not only the colouring, but the light and shade upon an insect assist in rendering it inconspicuous. In this connection we may well quote Professor Poulton upon the pupa of the Purple Emperor, Apatura iris: "The most extraordinary thing about this resemblance is the impression of leaf-like flatness conveyed by a chrysalis, which is in reality very far from flat. In its thickest part the pupa is 8.5 millimetres across, and it is in all parts very many times thicker than a leaf. The dorsal side of the pupa forms a very thin, sharp ridge for part of its length, but the slope is much more pronounced in other parts and along the whole ventral side. But exactly in these places, where the obvious thickness would destroy the resemblance to a leaf, the whole effect of the roundness is neutralized by increased lightness, so disposed as just to compensate for the shadow by which alone we judge of the roundness of small objects. The degree of whiteness is produced by the relative abundance of white dots and a fine white marbling of the surface which is everywhere present mingled with the green. The effect is, in fact, produced by a process exactly analogous to stippling. The degree of lightness produced in this way exactly corresponds to the angle of the slope, which, of course, determines the depth of the shadow. By this beautiful and simple method the pupa appears to be as flat as a leaf which is only a small fraction of 1 millimetre in thickness."

The protective colouring of certain Lepidopterous larvæ varies with their surroundings; thus, the larvæ of 
the Peppered Moth, Amphydasis betularia-larvæ of one brood, when fed upon green leaves, become green in colour; others of the same brood and fed in a similar manner, when compelled to live upon brown twigs, in nearly every case became dark brown.

There are insects, too, which, apparently instinctively, seek to hide themselves where they are least likely to be observed. The Cotton Boll Weevil, Anthonomus grandis, is a case in point. Of a dull earthen brown, this Weevil is by no means difficult to detect as it climbs over the cotton plants. In the presence of danger it at once drops to the earth, a common Weevil habit, by the way, and so closely resembles its surroundings that it is easily overlooked. This is but one example of hundreds. Many Lepidoptera, when at rest, so arrange their wings that their colouring may afford them the maximum of protection. Species with brightly coloured hind-wings but sombre fore-wings will invariably be found resting on some lichen-covered post or tree or a rock, with their wings so folded that the bright colours are hidden from view. Species whose under-sides harmonize with their surroundings rest with the upper surfaces of their wings in contact, so that only the lower surfaces can be seen. Other species, if their upper surfaces afford the best protection, sleep with their wings horizontal, and there is a case on record in which one species of Butterfly rests in one district with its wings vertical and in another district with them horizontal, for the evident reason that the positions it has chosen afford the best protective colouring for the respective districts.

Many larvæ spinning silken cocoons have the power of making the colour of the silk approximate closely to 
that of their surroundings. With all their wonderful protective colouring, however, no adult insects have the power of varying their colours at will to suit their environment, after the manner of chameleons.

The brightly coloured, conspicuous insects mentioned at the beginning of the chapter are to be found everywhere. What is the object of their brilliant colouring? A few words will suffice to explain. Their ornate hues are designated warning colours for the reason that in almost every case the brightly coloured insect is unpalatable. Animals of various kinds, insectivorous birds, reptiles, and the like, all avoid the brightly coloured insect as an article of diet. Many of these insects emit noxious acid or alkaline substances when touched, and the young predator, whatever be his kind, soon learns by experience to avoid such bedecked individuals Bright colours are not an absolute protection to every individual, for animals only learn by experience, and many insects are sacrificed that the majority may enjoy immunity.

Mimicry is another form of colouring worthy of consideration. Critics will decry the remark that mimicry is a form of colouring, but that is all it amounts to in many cases. Usually, however, in cases of mimicry form and colour go together. The object of mimicry appears to be either protective or aggressive: protective if the weaker, harmless insect mimics some more powerful species; aggressive if a predatory species mimics the insects upon which it preys.

Examples of protective mimicry are not hard to find. The Wasp Beetles mimic Wasps very closely in colour, and to some extent in form; we have a common British 
species, Clytus arietis. There is, however, an exotic species which carries its mimicry much further, for, in addition to its black and yellow colouring, its two membranous wings are so deeply indented that they closely resemble the four wings of a Wasp. Our Hornet Clearwing Moth, Trochilium crabroniformis, can hardly be excelled as an example of protective mimicry, for its resemblance to the Hornet Vespa crabro could hardly be more perfect in an unrelated insect. Many other examples are mentioned in our pages; in every case the mimic is benefited by its resemblance to a more aggressive species or to a distasteful species. Experience has taught the animal world in general that such species are best left alone; the mimic therefore shares in the comparative immunity enjoyed by the species it simulates.

On looking for the first time at any extensive collection of insects of various orders, the observant entomologist will notice that over and over again the same colourschemes are repeated in widely separated families or even orders. The resemblances of one group to another cannot be designated mimicry, and the matter has been summarized by Professor Meldola as follows: "From groups of species within the same order, such as Butterflies and Moths, groups of different genera of Wasps or Beetles, and so forth, we can gather a more widely abstract idea of types of warning colours common to whole tribes of insects, irrespective of the orders to which they belong. In other words, we can discern over and above the actual mimetic resemblance, which may be more or less exact, a kind of general similarity in design which suggests that certain types of patterns 
have been fixed by the action of natural selection as outward and visible signs of distastefulness. Thus, the yellow and black banded pattern so frequently observed in Wasps, Flies, Beetles, etc., is a very good example of a common warning type of pattern .... it is only necessary to add that from the insects inhabiting one district it is often possible to detect similar arrangements of colour and marking among Beetles of various families, Flies, Wasps and Bees, Bugs and Moths-a most heterogeneous assemblage of orders, none of the species being exact mimics of each other, and yet all presenting a general uniformity of colouring and pattern."

Aggressive mimicry is perhaps not quite so frequently met with as protective; still, it is common enough to be observed without much difficulty. Amongst the Robber-flies, Asilidoe, some of the most striking examples occur. Deromyia annulata bears a striking resemblance to the solitary Wasp, Polistes metricus; Bumble Bees are simulated by Robber-flies of the genera Mallophora and Dasylis - in fact, to such lengths is the mimicry carried in the former genus, that the hind-legs of the Flies resemble the pollen-bearing legs of the Bees. Many other examples could be quoted from the Robber-flies.

The little Sphegid, Oxybelus uniglumis (see p. 268) closely resembles, in appearance and habits, the Flies upon which she preys. In every case of aggressive mimicry the resemblance of predator to prey is of service to the former; it enables him to go amongst his prey without arousing suspicion, and to capture them without undue effort. It is only fitting to remark that there are those who will have none of the theory of aggressive mimicry. They argue that insects so well 
endowed for the capture of their prey as are most of these insects require no adventitious aid, but that their mimicry serves to protect them from still more powerful predators. We would remark, however, that the African native who, when hunting, covers himself with a skin, does so in order that he may approach nearer to his quarry, not that he may be protected from some unknown enemy, or, as Howard remarks, "We should not fear grizzly bear if they looked like peaceable human beings."

Not all of the aggressive mimics are active insects like the Robber-flies and Oxybelus; certain flower-like Mantids are also mimics of this type. Nearly all species of Mantis closely resemble their usual surroundings in colour; thus, the brown Mantids frequent brown vegetation, the green ones lurk on green leaves; but there are much more subtle mimics in the family than this. Hymenopus bicornis, a pink-and-white Mantid with flattened legs, is sufficiently flower-like to deceive nectarseeking insects; Dolium diabolicum, with four green legs and purple-and-white fore-legs and prothorax, is equally deceptive to insects. The Indian Mantid, Gongylus gongyloides, however, carries its mimicry further, and has been thus described from living specimens: "On looking at the insects from above they did not exhibit any very striking features beyond the leaf-like appendages of the limbs, both of which, like the upper surface of the insect, are coloured green; but on turning to the under-surface the aspect is entirely different. The leaf-like expansion of the prothorax, instead of being green, is a clear, pale lavender-violet, with a faint pink bloom along the edges of the leaf, so that this position 
of the insect has the exact appearance of the corolla of a plant, a floral simulation which is perfected by the presence of a dark, blackish-brown spot in the centre, over the prothorax, which mimics the opening to the tube of a corolla. A favourite position of this insect is to hang head downwards among a mass of green foliage, and, when it does so, it generally remains almost motionless, but at intervals evinces a swaying movement as of a flower touched by a gentle breeze; while in this attitude, with its fore-limbs banded violet and black, and drawn up in front of the centre of the corolla, the simulation of a papilionaceous flower is complete. The object of the bright colouring of the under-surface of the prothoracic expansion is evident, its purpose being to act as a decoy to insects, which, mistaking it for a corolla, Hy directly into the expectant, serrated, sabre-like raptorial arms of the simulator."

\section{Economic Questions.}

Frequently we read of plagues of Caterpillars, which devour every green thing as they advance like a destroying host; more frequently tidings reach us of some infantile epidemic which carries off young lives by hundreds. Do we ever give the matter a second thought unless it is brought home to us by personal loss? What matters it that Antler Moth larvæ are destroying the herbage on the Cumberland fells? Cumberland is far away. As for infantile diseases, how are they connected with entomology, anyway? The ordinary man, the well-educated man, has much to learn of insects, if he would play his part in making our land more habitable. What is true of Britain is doubly true of the tropics. 
Here the insect menace is bad enough; in tropical countries, where insect life attains its zenith, the matter is far more urgent.

From an economic point of view insects may be divided into two groups. There are insects which damage crops, either by using them as food or by destroying them for nesting purposes and the like. There are also insects which carry disease, from man to man, from animals to man, and from animal to animal. Examples of these destructive insects are mentioned here and there in our pages, but now we propose to review some of the more noxious, and to learn a little of their machinations.

The crop pests are countless. Every herbivorous insect might be described as noxious; the very fact that it eats vegetation is proof that it does harm, unless it be such an exceptional creature that it confines its attentions to noxious plants. The entomologist, however, is fair in his judgment; no insect is considered injurious unless by weight of numbers it does serious damage. The larvæ of the Swallow-tail Butterfly, Papilio machaon, feed upon the leaves of carrot, parsley, celery, fennel, and the like, but they are not common enough in this country to be classed as injurious insects. For the same reason, no one could consider the larvæ of the Death's-Head Hawk Moth, Acherontia atropos, to be injurious, though they feed upon potatoleaves.

Crop pests are mainly confined to the Lepidoptera, Orthoptera, Coleoptera, Diptera, Hymenoptera, Thysanoptera, and Rhynchota, a formidable array, to be sure, to which we may add the Isoptera, for we use the word 
"crop" in its widest sense, to mean any vegetation grown by man for his benefit.

The Lepidoptera may be considered as the most generally injurious. The adult insects are incapable of doing any damage; none of them have mouth-parts designed for biting, so they could do no harm if they would. Moths are the chief offenders, though our common "Whites," Pieris spp., are injurious to a limited extent.

Amongst the Noctuidoe there are many noxious species. The larvæ of many of these Moths, known in America as Cut-worms, hide beneath the soil by day and sally forth at night to feed; hence they are very difficult to deal with, and may be present in considerable numbers before the husbandman is aware of their presence.

Other damage done by Lepidopterous larvæ consists in defoliating trees and shrubs. Notorious species with this habit are mainly members of the Geometridoe, but it is by no means confined to this family, for several of the Lymantridae are voracious leaf-eaters. The Cossidae are noted wood-borers in their larval stages, and their immature existence is so prolonged that they are more harmful than insects of similar habit with a less extended life-cycle. Wood-boring larvæ also occur among the Sesiida, and many of them are capable of doing considerable harm.

Another description of injury, very common amongst certain Lepidoptera, is caused by the larval habit of leaf-mining; the Tineidoe are the chief offenders. Lastly there are the destructive leaf-rollers of the Tortricida, and the obnoxious " tent-makers," also mainly Tineidce. There are certain Lepidoptera which cannot accurately 
be described as pests of crops, yet must be mentioned here, for they can still less be classified with the diseasecarriers. Reference is made to such species as the Clothes Moths of the Tineida, Moths with grain-eating larvæ of the Pyralidae, and the Bee Moths.

Orthoptera are unsurpassed as crop pests when they descend upon their feeding-grounds in thousands, a habit common to several species of Acridiida. Certain of the Phasmidce are destructive to coconut-trees, and for the rest many Gryllidce are minor pests, and all Blattidce are obnoxious soilers of food.

The injurious Coleoptera are nearly as numerous as the Lepidoptera. Wood-borers there are in plenty amongst the Scolytidae, Bostrychida, Lucanida, Cerambycidoe, and Lamiida, to mention a few families. The leaf-eaters are almost as numerous; Chrysomelidoe, Halticidae, and Galerucidce are the worst offenders, not forgetting a large number of the Curculionidae. Then there are many species whose larvæ live for long periods underground, and levy toll upon the roots of growing plants; Melolonthidae, Rutelida, Dynastida, Cetoniida, and Elateridas are the offenders here. There are ravagers of stored grain amongst the Curculionidae, the Tenebrionida, and other families. There are twiggirdlers amongst the Buprestida, creatures of evil habit who kill the twigs of trees by eating away circular strips of bark. There are Lamiidce of almost similar habit who prune the twigs instead of ringing them. The evil ways of many Coleoptera are too diverse to be recounted in detail.

Amongst the Diptera there are Tipulidos with subterranean root-feeding larvæ. There are root and stem 
feeding larvæ and leaf-miners too, but it is mainly on the medical-or shall we say disease-bearing-side that Diptera make their presence felt.

The Hymenoptera are notorious as crop pests, almost solely on account of the damage done by Tenthredinidce larvæ. To a lesser degree, the Siricida, with woodboring larvæ; the Cephidae, with larvæ which tunnel in smaller stems; and the gall-forming Cynipida, are noxious.

The Thysanoptera are almost all of them injurious to growing crops, whilst the Rhynchota include some of the most harmful of all insects. With a few-a very few-exceptions, all the Coccidoe are noxious; there is probably no family containing so many injurious species: the Aphidoe are a good second. The Cotton-stainers of the genus Dysdercus are dreaded in every cottongrowing district. The Aleurodidoe and Psyllidos contain more harmful than harmless species. The Tingidoe and Jassidoe are harmful in a minor degree, a remark which applies to some of the Capsida. From their egg-laying habits the Cicadidoe cause indirect injury, and the leaf-eating species of Pentatomidas are not above suspicion.

Before passing to the medical aspect of economic entomology, let us see whether there is not a ray of hope amongst the wreckage. It is cheering to be reminded that nearly all these evil-doers have enemies amongst their own kind, often very closely related enemies. They belong, for the most part, to the Hymenoptera, Diptera, Coleoptera, Odonata, Planipennia, and Rhynchota.

Many Hymenoptera live at the expense of other 
insects. The Ichneumonida, Brachonida, and Chalcididae, and in a lesser degree the Evaniida and Proctotrypida, do immense service to mankind in keeping the numbers of noxious insects within reasonable bounds. In addition, there are many predators, such as the Fossorial Wasps, the Social Wasps, and the Ants, who levy no small toll on the insect world.

Several Diptera are parasitic, notably the Tachinida, and of predators none are more energetic or voracious than the Asilidoe.

The friendly Coleoptera form a limited band. Pride of place must be awarded to the Coccinellidoe, who in their varied species wage continual warfare upon Aphidce, Coccidoe, and the like. Then there are predatory species of Carabidoc-a few species are plantfeeders-and the still more useful Cicindelida.

The Odonata, as an order, are useful; they all devour insect fare, and most of them are indefatigable in their search for food.

The Planipennia include the Chrysopida, those inveterate enemies of Aphidac; and amongst the Rhynchota there are some carnivorous species, mostly Reduviidoe, which do some duty towards maintaining the balance of Nature.

The disease-bearing insects are confined to four orders-Diptera, Siphonaptera, Anoplura, and Rhynchota; nevertheless, they are all too numerous.

Amongst the Diptera we find the largest number of blood-sucking insects which affect man and his belongings. The Culicidae, in the main, are harmful, and all are annoying. Malaria and yellow fever are transmitted by these insects. The Muscidae are equally objection- 
able; the House-fly is responsible for the spread of several diseases. The Tsetse-flies transmit sleeping sickness and an allied disease to animals. The Simulidoe are more than suspected of conveying pellagra, and certain Psychodida of performing the same office for the unknown germs of three-day fever. The Tabanidce, too, are under suspicion in connection with the transmission of disease. The Estridae are all of them noxious to animals, though not disease-carriers. Other parasitic Diptera occur in the Hippoboscidoe and allied families in the Muscidce and Sarcophagida, species of some of these two families being parasitic on man.

Certain species of the Siphonaptera are notorious as vectors of the plague bacillus; other species are internal parasites of men and animals; most species are annoying partial parasites.

The Anoplura include disgusting, disease-bearing human parasites, and the Rhynchota are notorious because they include the Cimicida, of which family the common Bed-bug, suspected of transmitting recurrent fever, and a disgusting creature at best, is a member.

These insects, in common with their crop-devouring relations, have their enemies, both parasitic and predatory; were it not so, there would be no place for man upon this earth.

There are a certain number of insects from which we derive direct benefit; they can almost be counted upon the fingers of one hand. True, the enemies of our enemies-insect allies they may be termed-are beneficial to us but indirectly.

The Silkworm and the Honey Bee, semi-domesticated insects both, are the chief insects from which we derive 
benefits in kind. Then there are a few lesser-known species. Curiously enough, from the highly injurious family of Coccida these insects are mostly derived. The Lac insect, an Asiatic species, provides us with shellac; the Cochineal insect was once the medium of a thriving industry in the Canary Islands, till the discovery of aniline dyes sounded its death-knell; the Chinese pela wax insect provides a high-grade wax-and these three insects are all Coccidae! Certain Cynipida which make galls, used in the production of ink, and a limited number of species of various orders which provide food for people of depraved taste, complete the list of directly beneficial insects. 


\section{CHAPTER III}

COLLEMBOLA, THYSANURA, MALLOPHAGA, ANOPLURA, ODONATA, PLECOPTERA, EPHEMEROPTERA, ISOPTERA, AND ORTHOPTERA

\section{Order Collembola, or Springtails.}

WiNGLESS, minute insects; antennæ with few joints; six segments to the abdomen; biting mouths; metamorphosis slight. The springtails form a much neglected order, and there is a considerable divergence of opinion as to their classification.

ApHoRURID s. - Distinguished from all the other Collembola by the absence of any ventral spring on the abdomen. They are soft-bodied, slow-moving insects.

PoDURID s.-Ventral spring on the fourth abdominal segment.

Very common insects, but overlooked on account of their small size; some of them measure only a thirtieth of an inch in length. Achorutes dubius is a common British species, found on damp soil or even upon the surface of water. A. nivicola, an American species, occurs on snow.

ENTомовRYIDж.-Ventral spring on fifth abdominal segment; abdomen cylindrical, much longer than broad. Species of this family frequent greenhouses, bark of trees, damp soil, etc. The American Lepidocyrtus americanus is found in houses. 
PAPIRIIDe.-Ventral spring on fifth abdominal segment; abdomen very little longer than broad; last segment of antennæ short.

These insects frequent moss.

SMYNTHURID ж.-Ventral spring on fifth abdominal segment; abdomen very little longer than broad; last segment of antennæ long.

Many species are brightly coloured; they frequent fungi, decaying wood, and similar situations. Lubbock described the behaviour of the common yellow Smynthurus luteus as follows: "It is very amusing to see these little creatures coquetting together. The male, which is much smaller than the female, runs round her, and they butt one another, standing face to face, and moving backwaràs and forwards like two playful lambs. Then the female pretends to run away, and the male runs after her, with a queer appearance of anger; gets in front and stands facing her again; then she turns coyly round, but he, quicker and more active, scuttles round her, and seems to whip her with his antennæ; then for a bit they stand face to face, play with their antennæ, and seem to be all in all to one another."

\section{Order Thysanura.}

Wingless, minute insects with many-jointed antennæ; ten abdominal segments; slight metamorphosis; biting mouth-parts.

CAMPODEIDA.-Body hairy and terminated by two long appendages.

Minute insects, frequenting damp earth.

JAPYGD\&.-Body hairy and terminated by a pair of forceps. 
These insects resemble miniature Earwigs; they frequent moss, but nothing is known concerning their habits or life-histories.

LePismatid A.-Body covered with scales and terminated by three filamentous processes.

These are the well-known "Silver Fish." Lepisma saccharina is a common sight wherever starchy or sugary material is stored. It avoids the light and is difficult to catch, for its scales are easily shed and it slips from the grasp. Lepisma domestica, the "Fire Brat," haunts bakehouses and other warm situations.

MACHILID.-Machilis maritima is frequently met with on the sea-shore. Very little is known about the mode of life of these insects.

\section{SUBCLASS EXOPTERYGOTA.}

Order Malloplaga.

Wingless, parasitic insects with biting mouths; bodies hard and flattened; large flat heads; antennæ three to five jointed; eyes simple; legs strong, the fore-legs not used for walking; metamorphosis incomplete.

These insects are known as Bird Lice in contradis tinction to the Anoplura, or true Lice. The majority are parasitic upon birds, but several have mammals as their hosts. Unlike the true Lice, they are not bloodsuckers, but find their sustenance on scurf, scales of feathers, etc.

The order comprises four easily recognized families. The species of two families have clubbed, four-jointed antennæ, and of these the species with one tarsal claw belong to the Gyropidae and are parasitic on mammals; those with two tarsal claws belong to the Liotheidae 
and are parasitic on birds. The members of the family Trichodectidae, parasitic on mammals, all have three jointed, filiform antennæ and a single tarsal claw; whilst those of the remaining family, Philopterida, also have filiform antennæ, but with five joints; and their tarsi are armed with two claws; they are parasitic on birds. From these remarks it is clear that the two-clawed Mallophaga are bird parasites, and the one-clawed species have mammalian hosts.

The typical life-history of a Mallophaga may be taken as representative of the whole order. The female deposits her elongate, oval eggs singly upon a feather or hair, according to her host. The immature Lice break off a lid from the free end of the egg, and come into the world not very dissimilar in appearance to their parents. Naturally, they are smaller, their heads are larger in proportion, and their body-markings are not distinct. By a series of moults they attain the adult stage. Bird Lice never wander from the body of the living host; it is true they will pass from host to host when they are in actual contact with one another, and then only. It is remarkable, therefore, that the same species of Mallophaga may be found on totally dissimilar hosts in both the Old World and the New.

Aquatic birds have their biting Lice, not specially modified for life in the water, but protected, probably, by the close-growing feathers of their hosts. One species feeds upon the epidermal scales inside the pouch of the pelican, but the student of biting Lice would be well advised to begin with the domestic hen, which may harbour five species of three genera, amongst them the typical Menopon pallidum. 
Order ANoplura, or Líce.

Minute insects with large abdomens; antennæ fivejointed; wingless; mouth suctorial; tarsi with one claw.

The order is composed of the single family Pediculida, or True Lice; there are four genera and a limited number of species. All the Pediculidoe are parasitic upon mammals, and three of them are the particular adjuncts of man. Till comparatively recently but little has been known of these insects, but with the attention that is now being paid to medical entomology, and the undoubted connection between Lice and the spread of disease, more and more of their history is unfolded.

Concerning the exact systematic position of these insects there is still some doubt. Certain authorities look upon them as degraded Hemiptera-degraded through a long period of parasitic existence. Others, again, consider them to form a distinct order, to which the names Siphunculata and Anoplura have been applied.

There are three species of human Lice, belonging to two genera, or, according to Meinart and some others, two species of different genera. The Head Louse, Pediculus capitis, as its name indicates, makes its home on the heads of human beings. Its eggs, which are laid singly on the tips of the hair, are the all too familiar " nits." It is a curious fact that the Head Lice affecting men of various races vary in colour according to the hue of their host's skin. This has given rise to the yet unproven theory that there may be a number of species of $P$. capitis. The Body Louse, $P$. vestimenti, is very similar to the Head Louse, so similar that doubts have 
arisen as to its being a distinct species. In habits, at any rate, it differs markedly from capitis; it does not dwell in the human head, but in clothes, from which it sallies forth to take its toll of human blood. It is one of the most prolific of insects. The Crab Louse Phthirius inguinalis, frequents the coarser hairs of the human body, and in serious cases may even extend to the beard and eyebrows; but it never infects the head, for the good reason that its claws are unfitted for grasping fine hair. It is a shorter, broader insect than either of the species of Pediculus, and not unlike a small crab.

It is a peculiarity of true Lice that they do not attack mammals promiscuously; each Louse species is confined to a special species of mammal or to closely allied species. The Lice of domestic animals belong, for the most part, to the genus Hamatopinus; dogs, hogs, horses, cattle, and sheep, all have their particular Lice. Monkeys, though never attacked by Fleas in a state of nature, are infested by a Louse of the genus Pedicinus, which is peculiar in having only three joints to its antennæ. It is a curious, though unimportant, coincidence that the Elephant Louse, Hcomatomyzus elephantis, is, like its owner, possessed of a long proboscis. The Horse Louse, Homatopinus asini, is not unlike the Crab Louse, but larger and armed with much more formidable claws. Even aquatic mammals are not free from the attentions of these degraded insects. Seals have a genus of their own-Echinophthirius, and none of the individuals suffer the slightest inconvenience from the lengthy submersion to which they are subjected by their hosts. 
Order Odonata, or Dragon-flies.

Wings devoid of scales and never folded, elongate, of nearly equal size, and much veined; eyes large; antennæ small and short; legs not adapted for walking; jaws well developed; larvæ and pupæ aquatic.

The Dragon-flies are among the most beautiful of our native insects; many are so swift of flight that it is often difficult to observe all their beautiful metallic and iridescent colouring, as they dart hither and thither in search of their prey. Although perfectly harmless to man and his belongings, some of the larger species are of fearsome aspect, and this has given rise to many ill-founded stories. In some parts of England these insects are known as " horse-stingers," despite the fact that they could not sting had they the desire to do so. They are also called " Devil's darning-needles," because they are reported to sew up the ears of bad boys; "snake-feeders" they are called too: they are supposed to supply food to water-snakes. In Scotland they are often referred to as "flying adders." In truth they are very beautiful, harmless insects.

A few details concerning the general structure and habits of the Odonata may not be out of place, especially as these insects differ from all others in certain essentials.

Although all Dragon-flies bear a certain family likeness to one another, there are, as in all orders, great differences in size and build. They vary in size from Mecistogaster lucretia, a South American species, which measures six inches in length and five inches from tip to tip of its wings, down to minute Sympetrums; in stoutness, even among our own species, from the portly 
Libellula depressa to slender Agrionids. In all species their heads are remarkable for their large size and the inordinate amount of rotation of which they are capable.

Structurally, the most interesting feature of the adult males is the separation of the ejaculatory ducts from the intromittent organs. The former are situated on the penultimate abdominal segment; the latter on the ventral side of the second abdominal segment. When copulation is about to take place, the male curves his abdomen so that its penultimate (ninth) segment is in contact with the second, and pours the semen on to the intromittent organ. During copulation the male grasps the female round the neck with the claspers at the end of his abdomen, and she curls the tip of her abdomen round, in contact with the second abdominal segment of the male. Frequently the male retains a hold of his mate even during egg-laying, and should she be one of the species given to laying her eggs under water, he will follow her into that element rather than relax his hold.

The means by which Dragon-flies capture their prey is uncertain. That it is always captured on the wing is well known, but the flight of these insects is so rapid, they change their direction so suddenly, that the actual capture is a matter of conjecture. The small insects, of which Dragon-flies consume a quantity, are apparently seized in the jaws; the larger ones are probably seized by the legs and devoured during flight. At least, their legs are well placed for such a happening; they are all placed well towards the front of the thorax, and are curved forward in flight. 
PLATE II

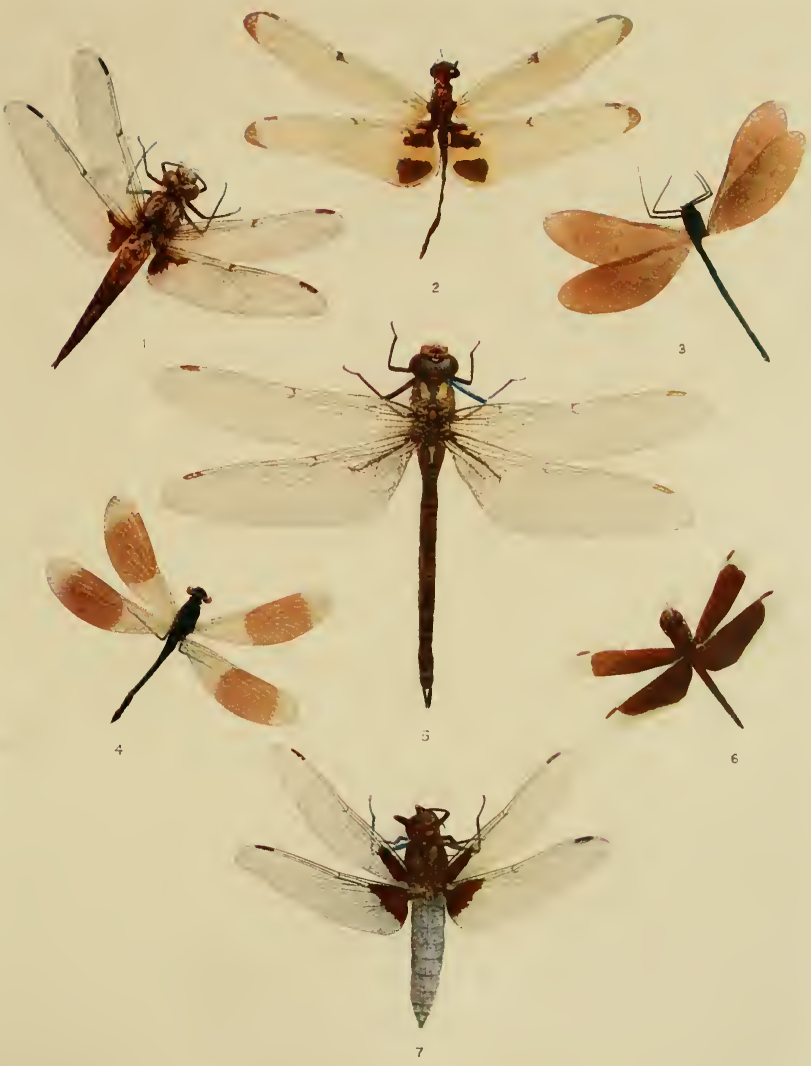

I GROUP OF DR.IGON FLIES 

"Flies seem to be their commonest food, but large dragon-flies will eat small ones. Leaf-hoppers and even small butterflies and moths are captured by them. Some forms will occasionally pick up a moth from a weed or a grass stem on which it is resting, and even one of the large swallow-tailed butterflies has been seen captured by a dragon-fly, while Williamson states that he once saw one holding a large wasp in its jaws. The voracity of a large dragon-fly may easily be tested by capturing one and holding it by its wings folded together over its back, and then feeding it with live house-flies. I should hesitate to say how many it will accept and devour, as I never tried one to the limit of its capacity. Beutenmüller found that one of the large ones would eat forty house-flies inside of two hours, while a smaller one ate twenty-five in the same time. It is an odd fact that a dragon-fly will eat its own body when proffered to him. Even when insufficiently chloroformed and pinned, if one revives, it will cease all efforts to escape if fed with house-flies, the satisfying of its appetite making it apparently oblivious to the discomfort or possible pain of a big pin through its thorax."

The life-histories of the various species of Odonata differ from one another in minor details, but in general they are very similar. The female deposits her eggs in water, either by dropping them on its surface, by attaching them, enclosed in a mucilaginous envelope, to some water-plant, or by inserting them in the stems of aquatic vegetation. The species which have the last-named habit are provided with pointed or roughened sides to the vulva. The females, enclosed in a film of 
air, descend the stem of the plant they have selected to a point well below the water-level, cut or file a slit in their plant tissues, and deposit their eggs therein.

The larva appears in about a month, and at once takes to a predatory life, walking slowly on the bed

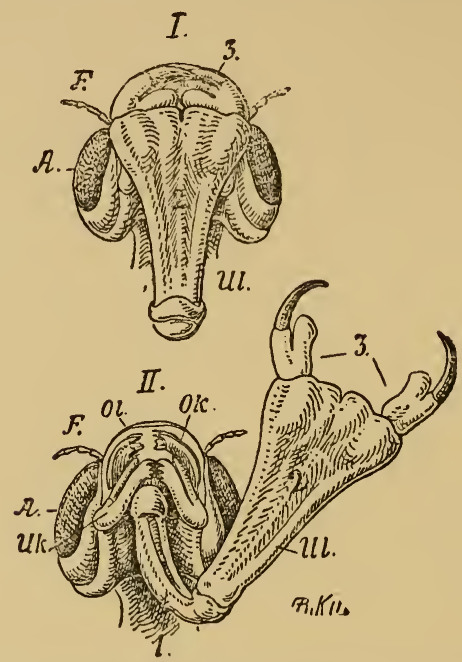

Fig. 1.-Head of Larva of Blue Dragon-Fly (viewed fro. Below). (Much Magnified.)

$I$, With mask folded up; $I I$, with the same unfolded. $A$, eyes; $F$, antennæ; $O l$, labrum; $O k$, mandibles; $U k$, maxillæ; $U l$, labium, having the form of a mask; 1 and 2, its two elongated portions; 3 , the pincer-shaped portion.

of the pond as it stalks its prey. Its colour renders it inconspicuous on the mud, and its mouth-parts are well adapted for its mode of life. The lower lip, which is hinged below the mouth, is elongate, and when at 
rest extends below the head; at its distal end there is hinged another long segment with two sharply curved teeth (forceps) at its free end. This second segment, at rest, lies below the first; the whole covers the lower face like a mask-in fact, it is usually so called. "When it is folded, the head of a dragon-fly larva, seen from the front, looks like that of a bull-dog. It is more innocent-looking than that of a bull-dog simply because we know what a bull-dog can do; but the moment that the larva approaches near enough to its prey, the innocent-looking mask is unfolded and darted out, and the probably unsuspecting aquatic insect or small fish is seized by the teeth at the extremity and drawn back into the mouth."

The respiration of the larva varies according to the species. In some there are external gills on the tail and sides of the abdomen; in others there are so-called "rectal gills," and for their aeration water is sucked into the rectum. Frequently the larva ejects this water so violently that it propels itself for a considerable distance.

Many moults are passed through by the Dragon-fly larva, and after the third or fourth the wing rudiments, in the form of two minute lobes, appear on a pair of horny plates which were visible in the earlier stages. The larva has now become a nymph. Many more moults are accomplished before the nymph is ready to change into the active, aerial Dragon-fly; during this time the nymph breathes by means of thoracic spiracles. When at length the change is about to take place, the nymph, deserting its aquatic home, climbs up the stem of a water-plant and clings firmly 
thereto. After a space, the nymphal skin splits down the back, and the wings, head, and thorax are freed, but the tip of the abdomen still remains within the skin. The next part of the process is the backward bending of the Dragon-fly, and in this apparently uncomfortable

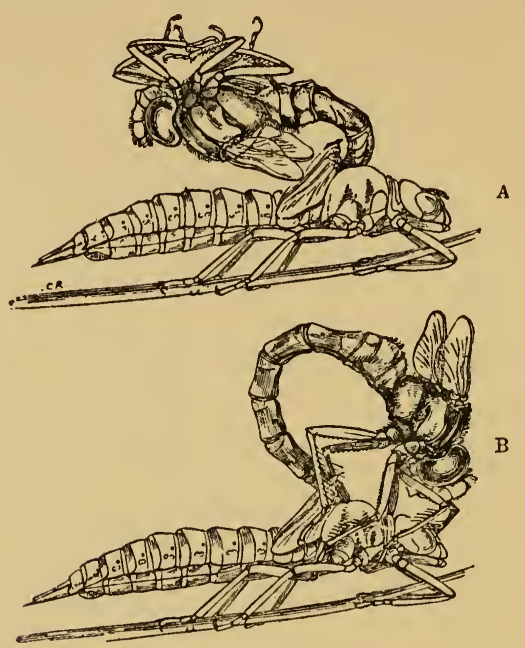

FIG. 2.

$A$, The anterior portion of the body of a dragon-fly freed from the nymphal skin; $B$, The tail being extricated.

From "Zoology of the Invertebrata," by A. E. Shipley.

position it will remain for several minutes, waiting for its legs and wings to harden; then, bending forwards once more, the old skin is seized by the insect's legs, its abdomen arched, and its tip carefully withdrawn from the nymphal skin. Now completely free, the adult Dragon-fly crawls away from its abandoned 
covering, but its wings and abdomen are still in an imperfect stage. For some hours the newly awakened

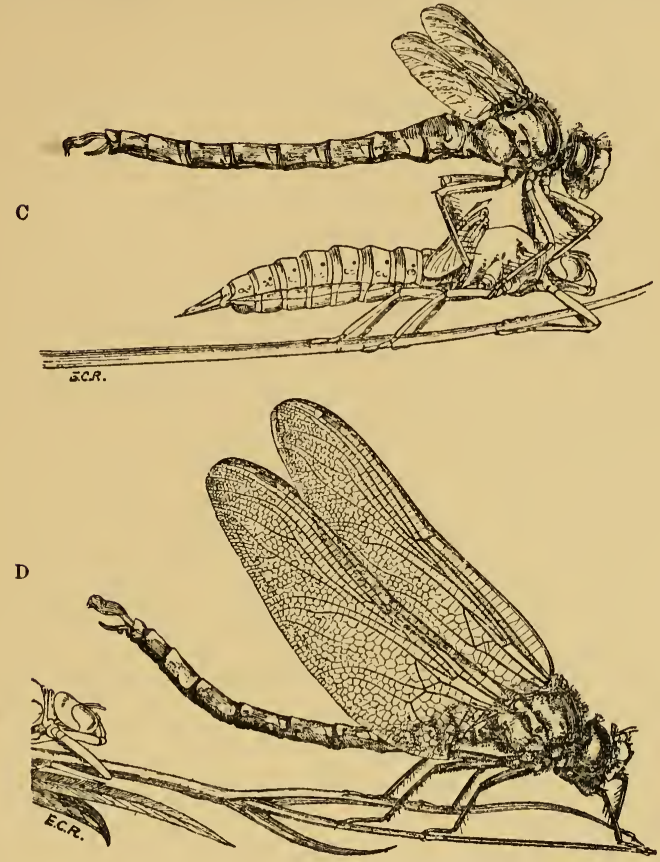

FIG. 3.

$C$, The whole body extricated; $D$, the perfect insect Eschna cyanea, the wings having acquired their full dimensions, resting to dry itself, preparatory to the wings being horizontally extended.

From " Zoology of the Invertebrata," by A. E. Shipley.

insect clings to its support, the while its wings expand, its abdomen assumes its normal proportions, and the full splendour of its brilliant colouring comes to it. 
In general, Dragon-flies are beneficial insects. Their larvæ may do some damage to fish-fry, but the adults are highly destructive to insects, many of which would prove injurious if allowed to increase to a great extent. Unfortunately, the Dragon-fly is an insect likely to become. more and more scarce as drainage becomes more common. From the nature of its life-history water is an essential to its existence. Sometimes, when ponds dry up, these insects migrate in enormous numbers. Mandt, describing one of these migrations, says: "The air for miles around seemed literally alive with these dragon-flies (Aschna heros) from a foot above ground to as far as the eye could reach, all flying in the same direction, a south-easterly course, and the few that would occasionally cross the track of the majority could all the more easily be noticed from the very regular and swift course they generally pursued; but even these few stray ones would soon fall in with the rest again. Very few were seen alighting, and all carefully avoided any movable obstacles."

The order is divided into seven subfamilies, which are easily distinguished by the characters given below.

CALOPTERYGID \&.-Fore and hind wings similar, held vertically in repose; eyes constricted at the base; at least five cross-veins between the first and second longitudinal veins, running from the node (the apparent break on the front margin of the fore-wing) to the base.

The species of this family are noted for their beautiful colouring. We have two in Britain, known as "Demoiselles" or "Kingfishers." Calopteryx virgo has beautiful metallic blue wings in the male and brownish, often tinged with green, wings in the female. The 
females of $C$. splendens have greyish wings, but the males have their transparent wings broadly banded at their centres with deep blue. One of the most beautiful species, however, is the common East Indian, $C$. chinensis, whose males have transparent fore-wings and brilliant green hind-wings. The American genus Hetcerina may be recognized by the blood-red patch at the base of the transparent, somewhat narrow wings of the males.

Our British species may often be seen flying low over streams; the larvæ of all members of the family breathe by means of tracheal gills.

AGRIONID x.-Similar to Calopterygida, but with only two cross-veins between the first and second longitudinal veins running from the node to the base.

This is a large family of slender, graceful insects. Most of them are small, though some of the South American forms equal any of the Odonata in size. In an order of active Flies they can only be described as poor on the wing.

Our two commonest native genera are Agrion and Lestes, and they are easily distinguished, though both have transparent wings. At, or near, the tip of the fore-wing of all Dragon-flies there is an opaque spot, known as a stigma. The size, shape, and often the colour of the stigma vary in different species. Species of Agrion have small lozenge-shaped stigmas; in those of Lestes they are large and oblong.

The bodies of all the species of this family are highly ornate, metallic blues and greens being the predominating colours; the larvæ breathe by means of tracheal gills. 
Gомрншж.-Front wings dissimilar from hind-wings, held horizontally in repose; eyes not constricted, but wide apart.

These insects are sometimes referred to as the true Dragon-flies; by many authorities they are considered to form a subfamily of the Esschnida. Most of the species are large, and many possess abdomens of peculiar swollen form; this is well seen in Gomphus vastus. They are not good performers on the wing, and the females only take to flight at infrequent intervals. The eggs are deposited on the surface of the water, and not upon aquatic plants.

Cordulegasteride. - Similar to Gomphida, but their eyes touch at a single point at the top of the head.

These Dragon-flies are moderately large insects, and they have been given their family name because of their club-shaped abdomens, which are narrower in the middle than at either extremity. They also are often considered as a subfamily of the AEschnidae.

All of them are strong fliers; their wings are usually clear or nearly so, and they lack the beautiful metallic colouring which renders the species of other genera so attractive. Their bodies are usually banded with brown or yellow. Our common Cordulegaster annulatus is a large, powerful insect, measuring upwards of four inches in wing-span. It is black in colour, and has its abdomen banded with yellow and its thorax striped with the same colour.

Aschnme.-Similar to Gomphidae, but their eyes meet on the top of the head for some distance, and the three ocelli are arranged in a straight line on the front of the head. These are among the largest and most powerful 
of all Dragon-flies; all the species are exceedingly strong on the wing, so much so that they may often be observed flying far from the neighbourhood of water.

AEschna cyanea is one of the most beautiful of our native insects. In general colour it is reddish-brown; on either side of the thorax there is a large green spot, and there are pairs of similar coloured spots along the abdomen of the male; the female is distinguished by yellow spots. The hind-wings are larger than the front wings, and both are transparent. The equally common A. grandis is as large as its relative, but reddish-brown in colour with smoky yellow wings. The genus Anax also contains some striking species.

CoRDulides.--May be distinguished by the presence of a single tubercle on the hind-border of each eye.

Very closely allied to the Libellulidoe, and frequently considered as a subfamily. Many large species exist, and the wings of most of them are banded with brown, marked at the base with the same colour or clear.

Libellulm a.-Similar to Gomphidce, but the three ocelli are arranged in a triangle.

Many of these Dragon-flies have broad bodies, which give them a somewhat clumsy appearance; this is specially the case with the common Libellula depressa, of which species the males are blue and the females brown. L. quadrimaculata is equally common, but more elegant; it is yellowish-brown and has a dark spot at each node and on each wing-tip-hence its name.

The genus Sympetrum includes species of more slender build, and the black S. scoticum is not uncommon. Orthetrum is another genus with British species. 
Order Plecoptera, or Stone-flies.

PERLID \&.-Four membranous wings; the hind-wings much larger, though not longer, than the front wingsfolded when at rest; antennæ long and thread-like; body long, soft, and often broad, bearing a pair of short, moderately broad filaments at the apex.

The order consists of but a single family whose species bear a superficial resemblance to the Caddis-flies. The common British species is Perla bicaudata. It is a very sluggish pale brown insect, and may often be seen basking on stones near water in the summer. It rarely takes to flight, and is a poor performer. Anatomically these insects are interesting on account of the wellmarked divisions between the three segments of the thorax-in fact, the head and thorax of the common Stone-fly equal half the length of the whole insect.

The minute eggs are contained in a membranous capsule, and are carried for a while by the female before she deposits them in the water. Each female may deposit upwards of six thousand eggs, a necessary proceeding, for the larvæ are favoured food of fishes, so that their mortality is great. The larvæ are very similar to the adults, except that they lack wings; they possess anal filaments and long antennæ. Although capable of swimming, most of their time is spent beneath stones in swift-running streams, a position which their flattened bodies enable them to take up with ease The mortality among the larvæ is increased by the fact that their larval life is protracted and, as so often happens in such cases, the adults live but a few hours. 
The food of the " creepers," as Perla larvæ are called, consists of minute aquatic animals, and bicaudata breathes by means of paired tracheal gills. In some species there are neither gills nor spiracles, so that respiration takes place through the skin. This mode of breathing is uncommon among insects, and is only found elsewhere in the larvæ of Chironomidae and of some parasitic Hymenoptera.

The nymphs leave the water before changing to adults; they climb on to some near-by stone, their skin splits, and the Stone-fly emerges. Although the prevailing colour of Stone-flies closely approximates that of the stones on which they bask, there is an Australian genus, Chloroperla, whose species are green.

\section{Order Ephemeroptera, or May-flies.}

EPHEMERIDÆ.--Hind-wings much smaller than front wings, and not folded when at rest; abdomen bearing two or three long, slender filaments; antennæ short.

These insects are usually known as May-flies, sometimes as Day-flies, and by fishermen they are called Green or Brown Drakes. Their larvæ and nymphs are aquatic There is but one family in the order, and our common May-fly, Ephemera vulgata, is a typical species.

The females, after pairing, an act which takes place in the air, deposit their disc-shaped eggs on the surface of the water, and they sink to the bottom. The larvæ, as soon as they hatch, bury themselves in the mud and start on their long larval life, which extends as long as three years; during this time they undergo at least twenty moults. Their food consists mostly of vegetable matter, and respiration is carried out by tracheal gills 
assisted by three filamentous outgrowths from the tip of the abdomen.

Then, when the larvæ have changed into nymphs and the latter are ready to take to the air, there happens an event which is not paralleled among any other insects. The nymphs rise to the surface of the water, there is a brief pause, their nymphal skins split, and they fly into the air, not as perfect insects, but as subimagos. The young subimagos seek some near-by resting-place, and another skin is shed and the grey adult May-flies appear.

The adults of vulgata have three tail filaments and very short antennæ; their fore-legs, which are useless for walking, are carried in front of the head, and at a distance might be mistaken for antennæ. They have incompletely formed mouth-parts, and are incapable of taking in food; could they do so, their intestines are not capable of digesting any nutriment. The lives of the adults are short, though not so short as is popularly supposed and as their family name-derived from the Ephemerides of Greek mythology, who lived but a day. A case is on record of an adult Ephemerid which lived for three weeks, but it must have been a particularly robust individual.

Kirby relates that the European Oligoneuria rhenana, a white species, " appears in such vast numbers on the Rhine after sunset as to resemble snowflakes."

Order Isoptera, or Equal Wings.

Termitid e.-All four wings of equal size; males and queens winged, workers wingless; biting mouths well developed; body oblong and depressed; social insects. 
The order is composed of the single family Termitida, and its members are known popularly as Termites; a more common, but incorrect, name is White Antsthe Termites are neither Ants nor are they white. They are more nearly related to the Perlidce and Ephemeridoe than to the Formicidos; probably the fact that they are social and dwell in colonies has given rise to their popular name.

None of the species occur in Britain; a few are found in Southern Europe, but the order attains its highest development in the tropics. They are amongst the most injurious of all insects, and there are few timbers proof against their attacks. To be Termite-proof is one of the greatest recommendations that can be claimed for a wood destined for tropical use; there are a few such timbers, but not many.

Speaking of these insects, Oates in his "Matabeleland" says: "The White Ants kept tumbling over me all night, and knocking down leaves from the roof. These White Ants are the curse of all African travellers and settlers, devouring everything except iron and tin, whilst in time even houses succumb to their ravages. They form, however, an article of food in many places amongst the natives, by whom they are much esteemed on account of their slightly acid flavour. The enormous structures they erect are frequently carried up the trunk of a high tree, or may sometimes be seen standing alone at a height of eighteen feet.

"The Dutch Boers and others make use of these Ant-hills for cooking purposes, hollowing out the loose portion of the heap, and filling the hollow thus formed with wood, which is lighted, and, when consumed. 
renders the receptacle an admirable oven, retaining its heat for a great length of time."

In tropical Australia, Asia, and America, there are enormous colonies of Termites, and often their nests are structures as large as houses.

There is a great deal to be learned of the habits of these tropical Termites; so far as they have been studied the economy of one colony appears to be very similar to that in any other. Termes flavipes is one of the commonest European species; T. lucifugus is by no means rare in the Mediterreanean region; T. tubiformans, a Texan species, has the curious habit of constructing tubular shelters of cow-dung round the stems of plants. Another Texan species makes nests of the same material on tree-trunks. Of this species Buckley wrote: "They marched in dense columns along pathways leading to a hole near the base of a stump, into which they entered.... They dwell in the ground, where they have rooms, seldom more than one to two inches long, connected by tunnels. ... After rainswhich are of rare occurrence in that climate-they make semi-cylindrical tubes, which lie on the ground, with a length of from three to six inches. These arched ways sometimes intercept each other, being connected with chambers; but they rarely work by day above the surface, and never in bright sunshine."

The formation of a new Termite colony commences with the nuptial flight, in which winged males and females issue from the old nests in enormous numbers and come to the surface to pair. After pairing, the wings of both sexes break off, and the females either start new colonies of their own or, falling in with wing- 

PLATE IV
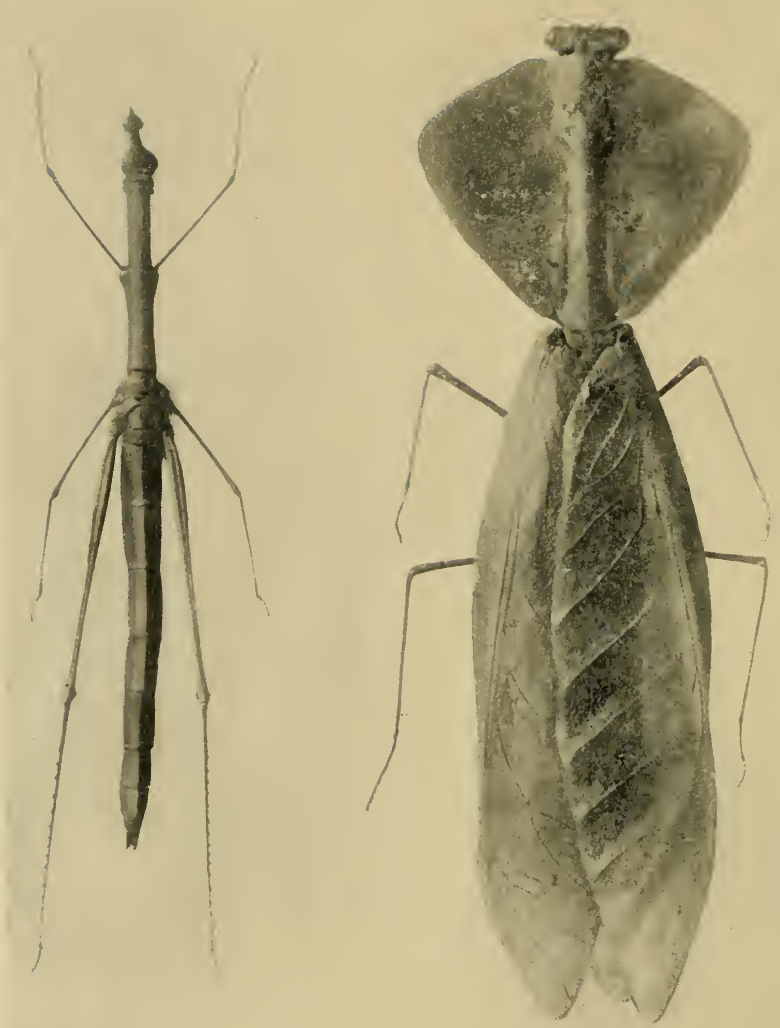

STICK INSEC'I

MIANTIS 
less workers from another colony, start their new home with their assistance.

Enormous numbers of Termites perish during these flights; as with the Seventeen-Year Locust (p. 119), the advent of innumerable individuals is the signal for all manner of enemies to gather to the feast so freely provided. That some fertilized females escape every danger is shown by the survival of the race.

Having reached a place of safety, after pairing, the female, who is now a queen and is probably assisted by workers, seeks a hiding-place where her new colony may be formed. For the rest of her life she becomes little more than an egg-laying machine; by the workers she is enclosed in a special royal cell in whose walls there are numerous holes, through which the workers may pass when carrying the eggs provided by the queen to other parts of the nest. In some of the tropical species the appearance of a fertile queen is extraordinary Her abdomen, distended with eggs, swells to the size of a small potato, thirty thousand times as large as that of a worker Termite. Her head and thorax form a mere spot at the end of this inordinately large organ. Her egg-producing capacity is prodigious, and is estimated at sixty a minute, or eighty thousand a day.

The larvæ are not nearly so helpless as those of the social Hymenoptera, and they are very soon able to fend for themselves. Their food varies, and may either consist of wood-fibre, their own cast skins, their own excrement, or regurgitated food. "When a Callotermes wishes for food," according to Grassi, "it strokes the posterior part of the body of another individual with 
its antennæ, and by some sort of a reflex action the contents of the alimentary canal of the individual stroked issue from the anus, and are devoured by the stroker."

In each colony there are always a queen, workers of at least two castes, and winged males. The workers are wingless females; they look after the queen and her eggs, and carry out other domestic duties in the nest; some of them become supplementary queens, capable of carrying on the duty of stocking the colony should any accident befall the true queen. The second caste consists of soldiers; they are individuals with enormously developed jaws; they are often five times the size of the ordinary workers, and, being unable to partake of ordinary food on account of their huge jaws, have cannibalistic tendencies, frequently making a meal off their fellows. In certain species there is yet a third caste, whose heads are modified into snout-like processes. These individuals are known as nasuti, or " nosed" ones, and their sole duties consist of mending the walls of the nest when they are broken, a feat which is accomplished by the aid of a fluid which exudes from the hollow snout.

A striking feature about every Termite nest is its extreme cleanliness; the insects even eat their own excrement again and again till all the nourishment is removed. Another feature, which the reader will probably have surmised already, is the presence of guests-they frequent the nests of all social insects.

Order Orthoptera, or Straight Wings.

Insects with biting mouths; front wings (tegmina) much narrower than the hind-wings and of a leathery texture; hind-legs of many species designed for leaping; 
metamorphosis incomplete; eggs often enclosed in a case.

This large order contains some of the most interesting insects; in habits they differ considerably from one another: some, the Mantids, are predaceous; others, the Locusts, are herbivorous; yet others, the Cockroaches, are practically omnivorous. In all the families - there are six in the order-metamorphosis is incomplete; the larvæ, except that they are wingless, are in all essentials miniatures of the adults. Although the Orthoptera receive their name from the straight margins of the tegmina which cover the membranous hindwings, there are some species with functionless wings and some that are wingless.

We have remarked that many of the Orthoptera are of great interest; to this order belong the curious Stick and Leaf insects, the wary Mantids, and a large number of musical insects. There is, in fact, no order containing a larger number of species exhibiting either protective or aggressive mimicry or singing powers. Despite their innate interest, many species are exceedingly harmful. Crickets are not the insects that the ordinary man would welcome in his house, Cockroaches are noxious creatures, and Locusts have been notorious since biblical times.

The six families of Orthoptera are easily distinguished; the earlier systematists separated the families with leaping powers (Saltatoria) from those whose members run over the ground (Cursoria). The same characters are still used in the classification of these insects.

BLATTID A.-Hind-femora similar to the others; head 
nearly horizontal; body flattened and oval (occasionally round); ovipositor concealed.

The Cockroaches, commonly but erroneously called Black Beetles, are all too familiar. The common Cockroach, by the way, is neither black nor is it a Beetle; how it came by its name is a mystery. Maybe the genius who founded the family is in part responsible, for the term Blatta means a Beetle.

In Britain we have at least two Cockroaches, the common species, Blatta orientalis, and the American Cockroach, Periplaneta americana. Neither of them is a native species, but of the various Blattidae that are introduced from time to time, they alone seem to have become established. $P$. americana is a chestnut-brown insect, considerably larger than its more common relative.

The common Cockroach is a dark brown insect, beautifully adapted for its peculiar mode of life. Both sexes are clad in a leathery armour, so smooth that they can only be held captive with difficulty. Their bodies are considerably flattened; in consequence they have no difficulty in crawling through narrow chinks in floors, etc. Their antennæ are long and thread-like, their long legs well armed with spines. The wingless females are longer and, in consequence, apparently narrower than the winged males.

A more detailed study of this insect will well repay the time spent upon it. The position of the head, typical of the Blattidae; the long antennæ, continuously vibrating, unless their owner is cleaning them by running them through his jaws; the bristles on the legs, used as body-combs (the Cockroach is clean in 
PLATE V

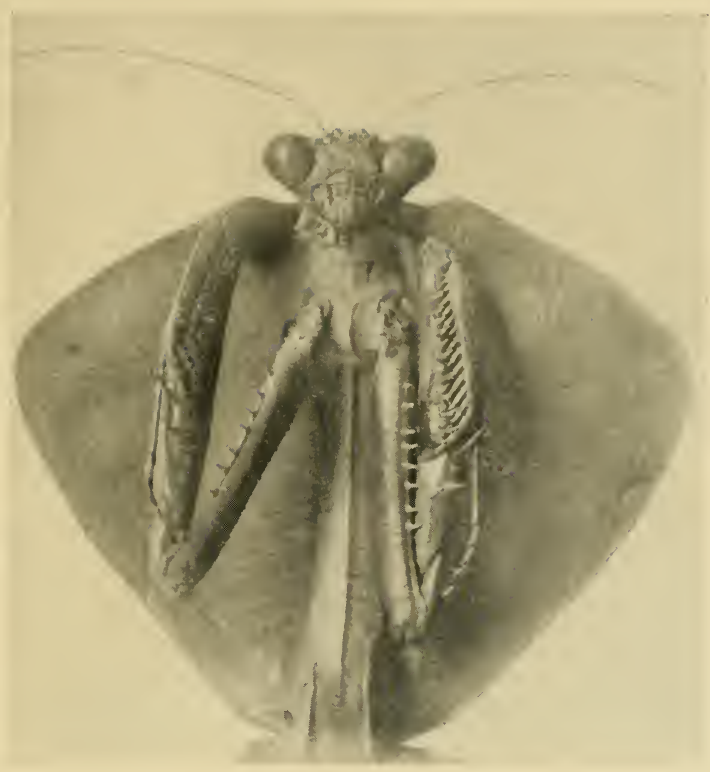

HEAD OF MANTIS

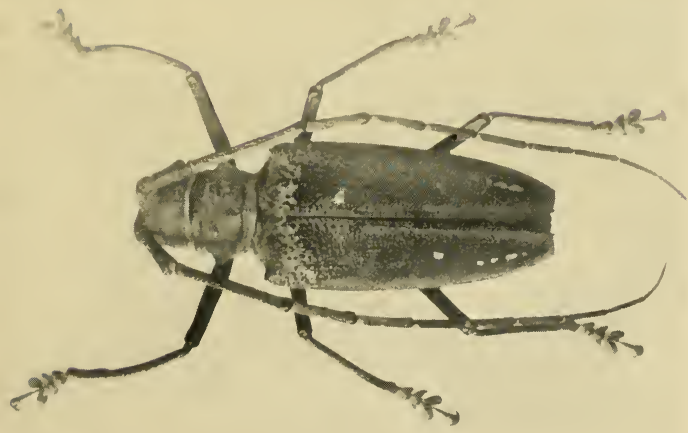



person, though his habits be repulsive); the padded feet, enabling their owner to walk up moderately smooth surfaces-these and a hundred other details may be learned from little more than a superficial examination of this familiar insect.

All Cockroaches appear to like warmth, and most of them shun the light; our common species is no exception. Breeding with orientalis takes place in the summer months. Each female lays sixteen eggs, and, as usually happens amongst the Orthoptera, they are enclosed in an egg-case. The Blattid egg-case is very similar to a purse with a snap opening; it is a small oblong sac, closed at the bottom and sides and capable of opening at the top, though held together by the tension of the edges. The egg-case is formed within the body of the mother Cockroach, where also the sixteen eggs are arranged in two rows, with the ends from which the larvæ will emerge pointing towards the top of the case. The female runs about, often for some considerable time, with the egg-case partly projecting from her abdomen, and not till she finds a suitable shelter will she deposit it. The larvæ, when they emerge, push their way through the opening of the case; they closely resemble the adults, but, of course, they are very small and have no wings; also they are pale in colour. They pass through a number of moults, and with each one they become more and more like their parents, darker and darker in colour, and at the final moult they attain their full sexual characters.

Cockroaches have many enemies, predaceous and parasitic; of the latter, the curious Evaniidce are the best known. 
Although the prevailing colour scheme of the order is some shade of brown, grey, or black, there is an American genus, Panchlora, with pale green species. Certain exotic species are brightly coloured; the Indian Corydia petiveriana is black spotted with yellow, and it is exceptional also in being round instead of oblong in outline. The giants of the family belong to the American genus Blaberus, and $B$. giganteus far exceeds all other Cockroaches in bulk.

MaNTID s.-Hind-femora not swollen; front legs designed for grasping; head oblique, generally triangular; prothorax long and slender.

The Mantis is an insect around whose supposedly pious habits a considerable amount of romance has been woven. Mantis religiosa, a common, green South European species, is so devout in its attitude that it has been named religiosa by scientists and "praying Mantis" by laymen. In truth, all the species of Mantidce are predaceous, and not only so, they are cannibalistic; the females never hesitate to seize and devour their mates if the latter are too pressing in their attentions. They are all exceedingly voracious, and Slingerland relates how "One Sunday a Green Mantis ate three Grasshoppers, each seven-eighths of an inch long, a daddy-long-legs, and then tackled another Mantis, and I was obliged to interfere with them."

The Praying Mantis has earned its name from its habit of remaining motionless for long periods with its front legs raised in the air, as though in the act of supplication. Its attitude, however, is not one of devotion, but of anticipation; in this position the Mantis awaits its prey, and should an unwary insect 
come within reach of the cruel, spiny, grasping forelegs, they are shot forward with lightning rapidity, the insect is seized, conveyed to the mouth, and eaten. All the Mantids capture their prey by stealth; they creep towards their victims at times so slowly and cautiously that their movements are imperceptible, but ever the grasping fore-legs await the moment to seize their prey.

Certain beautiful tropical species very closely resemble brilliant orchid flowers in colour and in form. These species bask on the orchid-plants, hopeful that insects bent on floral visitations will mistake them for blossoms.

Though the majority of Mantids are sombre in their colouring-green is a favourite hue-some species are quite ornate. The genus Harpax contains some striking forms, $H$. ocellaria, a West African species, having dark green tegmina, with a bright yellow eye-spot in the centre of each one.

As with all the Orthoptera, the metamorphosis of Mantids is incomplete. There is nothing very striking in their life-histories except the peculiar form of the egg-masses. These vary in form and minor details according to the species, but in every species the eggs are laid in parallel rows in hard and horny cases. The egg-masses, usually oval in shape, are attached to a tree-branch or other support, and the eggs are arranged on end down the centre. At first it was puzzling to know how the females could deposit their eggs so neatly within so hard a substance as that composing the body of the egg-mass. Further investigation showed that the horny substance is deposited by the female at the same time as her eggs, and that, when first formed, it 
is semi-liquid and frothy, only becoming hard in contact with the air. Despite the apparently impenetrable covering of the Mantis eggs, they are not without their Hymenopterous parasites.

Phasmid legs similar to the other legs; head nearly horizontal, generally quadrangular.

These are the great mimics of the insect world; the Stick and Leaf insects belong to this family. In point of size they are exceedingly variable; some of them are quite minute, while some of the tropical species measure as much as a foot in length.

All the Stick insects are sluggish in their habits; all are vegetable feeders, and many are highly destructive to crops; Lopaphus cocophages, a brown insect, is a notorious pest of coconut-palms, and when alarmed it has the objectionable habit of squirting an irritant fluid for some distance. In this connection, Kirby states that " one of the South African species is able to eject an offensive fluid a distance of five feet."

The Stick insects are remarkable anatomically for the great variation in the development of their tegmina and wings. Some species have short tegmina and welldeveloped wings; again, there are species whose wings and tegmina are both short; and there are other species, and they are many, which are completely wingless.

The life-history of a Phasmid is particularly interesting and very easy of observation. Hibernation takes place in the egg, and the young Stick insects hatch in the spring. They immediately make their way from the ground where they hatch to the twigs of some near-by tree or shrub, and then they remain motionless 
PLATE VI

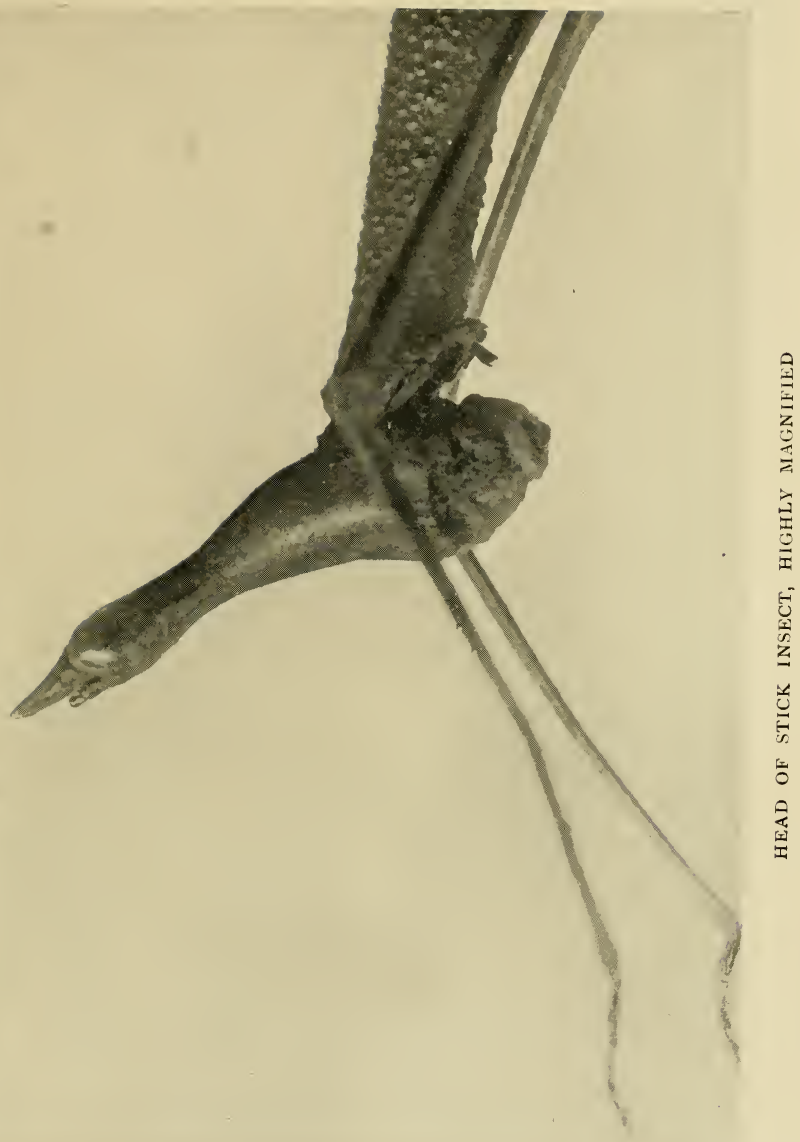



for days or weeks on end, their fore-legs stretched out in front of their heads to increase their resemblance to a twig, their green colour harmonizing with their surroundings. They moult but twice, and growth is rapid. At the last moult all the females and some of the males abandon their green colouring and become brown-at least, this is the case with many non-tropical species. The change is not without interest, for the plants upon which the Stick insects live are by this time losing their leaves, and will soon be little more than masses of bare, brown twigs, on which green Stick insects would be conspicuous. That all the males do not change their colour simply means that they are "following the rule, which holds more or less throughout nature, that the male sex is not so well protected as the female, since upon the latter depends the allimportant function of reproduction."

The eggs of Phasmidae are not enclosed in cases, nor are they attached to leaves, twigs, or other supports. Contrary to the usual Orthopteron rule, the eggs are laid singly and merely dropped on the ground. The eggs of all species bear a striking resemblance to seeds; some are of extraordinary form, and all have little lids which the larvæ raise when they are about to emerge. Once, in New York, the Thick-Thighed Stick insect, Diapheromera femorata, increased to such an alarming extent "that in autumn the dropping of the eggs on the leaf-covered earth sounded like a heavy shower of rain."

Among the winged Phasmids, the Brazilian Cyphocrania semirubra is the most striking; it has yellowishgreen tegmina and large pink wings. Curiously like a 
bamboo-stem is the green, wingless Phibalocera pythonius, and rivalling the Stick insects in bizarre form are the Asiatic Leaf insects of the genus Phyllium.

In habit and life-history the Leaf insects are very similar to the Stick insects. They are strikingly leaflike, with their flattened, expanded, green tegmina, and the resemblance is heightened in some species by the possession of leaf-like appendages on the legs. Some species have the outline of their leaf-like expansions so that they appear to have been eaten by larvæ round their edges; others are so marked that holes appear to have been bitten out of the inner portions.

GRYLLID E.-Hind-femora stouter than the others; tarsi three-jointed; antennæ long and slender; wings laid flat over the back.

This is the family of the Crickets, of which we have five species in Britain; three of them, the House Cricket, Gryllus domesticus, the Field Cricket, G. campestris, and the Mole Cricket, Gryllotalpa vulgaris, are quite common. The family is by no means large, and a study of the species will show that they fall naturally into three groups of types. There is the true Cricket type, as exemplified by G. domesticus; the burrowing type, with feeble or no wings, and front legs modified for turning up the earth: of these Gryllotalpa vulgaris is an example; the nocturnal Tree Crickets, which spend all their lives in trees: of these we have no native species.

Among the exotic Gryllidoe there are some formidable and repulsive-looking species. The Indian Schizodactylus monstrosus, a brown species, about an inch and a half long, is a hideous insect. Its wings and tegmina, which are longer than its body, are coiled in spirals at their 



$$
*
$$


tips; its tarsi bear curious leaf-like expansions which make the creature appear almost web-footed. The Australian Anostostoma australasice is but little more inviting-looking; the largest species of all, however, belong to the genus Deinacrida, and dwell in trees in New Zealand. "They are sometimes four or five inches in length, and their legs are very large and set with rows of very formidable spines, resembling those of a brier. The natives are afraid to climb the trees on account of these insects, which are able to inflict a very severe bite." From the same country comes Macropathus filipes, one of the most remarkable species of the family. The body of the insect is of reasonable proportions, not exceeding about an inch in length, but its antennæ often exceed the body-length by six or seven inches.

Among the wingless Crickets there are some curious forms, mainly belonging to the genera Callimenus and Brachyporus. They are quite unlike all other Crickets in appearance, and might be mistaken for enormous Wood Lice. Of the Tree Crickets, many species are exceedingly destructive to vines, raspberries, and other plants, for they all have the noxious habit of laying their eggs in the stems of these plants.

Locustrde.-Somewhat similar to Gryllidce, but tarsi four-jointed and almost identical in structure on all legs; ovipositor resembles a much compressed, sword-shaped blade; wings and tegmina roof-like.

The name of this family is likely to lead to confusion, for the members of the family are not true Locusts, as might be expected, but Long-Horned Grasshoppers. The true Locusts belong to the Acridiidoe, and, apart 
from any other feature, may be distinguished from the members of this family by their short antennæ. To avoid confusion this family is often known as the Phasgonurida; but, for reasons which do not call for explanation here, Locustidce is the better term.

Nearly all the Locustidoe have leaf-green tegmina, frequently veined with yellow or white, so that they have a very leaf-like appearance. There is a South American species, Pterochroza ocellata, which rivals the Leaf insect in its mimicry of foliaceous structures; its tegmina not only closely resemble leaves, but are so marked that they appear like leaves damaged by insects and upon which fungoid growths have settled. Another species, Myrmecophana fallax, mimics Ants in its colouring.

The largest British Locustid-our largest Orthopteron, in fact-is the Great Green Grasshopper, Locusta viridissima. It measures fully four inches in wingspan, but, despite its large size, it is rarely seen-not because it is uncommon, but because it is nocturnal in its habits.

In America certain species of Long-Horned Grasshopper are known as "Katydids," from the supposed resemblance of the male song to that word. To call the note of these insects a song is somewhat of an exaggeration, despite the fact that many species, notably Chloroscelus tanana, from South America, are kept in cages on account of their musical powers. Not long ago certain Japanese Locustidoe were on sale in London, and probably elsewhere; in their little wicker cages they were a novelty and caught the public fancy. Their " singingi" powers were feeble and monotonous, 
although the stock of one enterprising dealer bore the legend, "Sing like Canaries"-but there are canaries and canaries.

The note of Locustidoe and Gryllidoe is made by rubbing file-like patches on the under-surface of the tegmina against a ridge on the upper surface of the wing. The males alone "sing," and their song is always a love song. In both families auditory organs, in the form of oval membranous depressions, are found on the front tibiæ.

Many Locustids have tegmina curiously and regularly marked with black dots. The green Australian, Ephippitytta triginguttata, for instance, has a double row of. these dots upon its tegmina.

Several curious forms occur in this family; some species of Stenopelmatus are of evil mien, and the genus Cyrtophyllum has one or two species, notably C. crepitans, which are not remarkable for their beauty. The life-history of Microcentrum retinervis, so called from its reticulate tegmina, has been described by Howard. In America the insect is known as the Angular-Winged Katydid. Winter is passed in the egg stage, and the most curious fact about this insect is its curious method of oviposition. The flattened, oval, slaty-brown eggs are often deposited in the strangest situations: on the edge of a fence, for instance, and some " have been found on the edge of a freshly laundried collar which had been laid for some time in a bureau drawer. Riley records oviposition on the edge of a piano cover and on a long piece of cord." They are usually deposited, however, in double rows on twigs, and each egg slightly overlaps its neighbour, like 
slates on a roof. In the warmer States they are laid on the edges of leaves, "in which case one row will be found on one side of the leaf and the other row on the other side." Whatever the situation selected, the surface of the material on which the eggs are to be placed is first roughened in the jaws before the batch of from two to thirty eggs is laid. From one hundred to one hundred and fifty eggs are deposited by each female. The young Katydids, very pale in colour, emerge in the spring from the upper edges of the eggs.

ACRIDID\&.-Antennæ much shorter than the body; hind-legs with enlarged femora formed for leaping; ovipositor, a double pair of short plates divergent at the tip.

The family of the Locusts contains some of the largest as well as the most destructive insects. The South American Acridotheres dux is probably the largest insect known. Many individuals measure fully a foot in wing-span, with a body-length of four inches, but they are not nearly so destructive as their smaller, more active relatives.

In Britain we have several representatives of the family. The common Rhammatocerus biguttatus is a brownish or frequently greenish insect, with yellowishgreen legs. An interesting account of its habits appeared several years ago in the transactions of the Devonshire Association. The eye-witness of the proceedings said: "I have frequently observed our most abundant Grasshopper, R. biguttatus, sounding his music in the presence of and hopping round a female. Some years ago I was greatly amused as well as instructed by observing several insects of the same species, both 
PLATE VIII

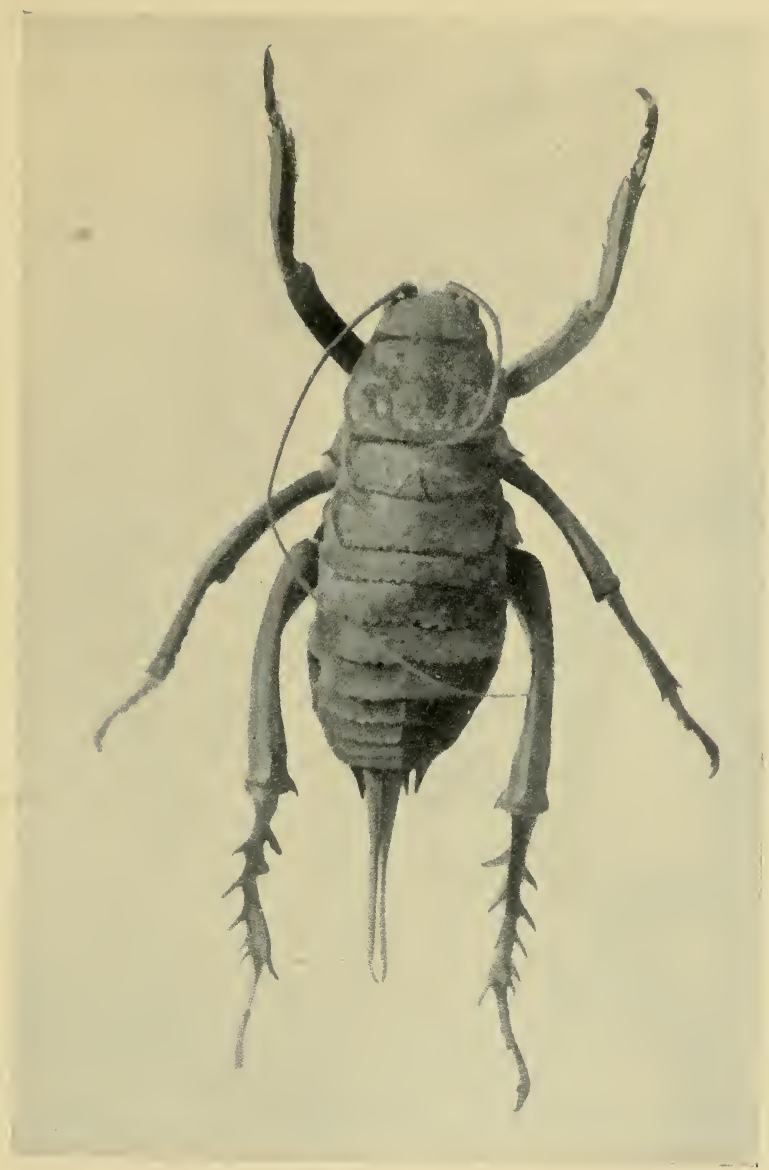

NEW ZEALAND CRICKET 

males and females. I was drawn to the spot by the extraordinary noise made by these creatures. It was a very hot day, and on a bare portion of a hedge-bank between Exeter and Budleigh Salterton. I cautiously crept up to the place from whence the sound proceeded, and there, to my delight, I first saw how these insects produced the sound which I had heard. In the centre of this group were several females, apparently listening to the concert; the males were, some hopping, some walking, and others gesticulating in the most ridiculous fashion around these ladies, and each playing to the
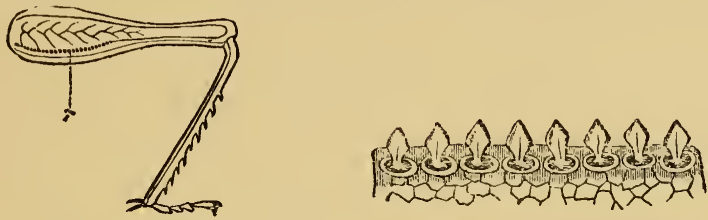

Fia. 4.-Hind-Leg of Field Locust. (After Landois.)

$r$, Row of chitinous teeth on the inner side of the femur. Opposite: some of the teeth strongly magnified.

best of his abilities on his peculiar musical instrument, no doubt to their great amusement and delight."

The sound-producing apparatus of the true Locusts and Grasshoppers is totally distinct from that of the Locustidce and Gryllidce. On the inner side of the hindfemora in the males there is a file-like ridge; this is rubbed against a ridge on the outer edge of the tegmina. The auditory organs are, as in the species of the other families, membranous depressions, but they are situated on the first abdominal segment. So far as we know, only the smaller species of the family are capable of producing sound; there are, however, auditory organs 
on many species whose note has never been detected by the human ear.

Some of the Acridiidae are of extreme beauty, and some of curious form. The large South American Titenacris albipes is one of the most beautiful members of the family. Its tegmina are dull green; the front margins of its wings are of the same shade, graduating into pale blue and then into a brilliant purple, the lastnamed being the prevailing wing colour. Here we may remark that, apart from their colouring, the wings of these insects are of great beauty. They are large and fan-shaped, veined with a number of veins radiating from the base, and with many smaller cross-veins. When not expanded, they are folded fanwise beneath the tegmina.

Of the curious forms, the species of the genus Truxalis are remarkable by reason of their elongate bodies and snout-like heads. The species of Cephalocoma are very similar in form, but their heads are more sharply pointed than those of Truxalis. In Tettix we find curious attenuated forms, whose general dorsal outline may be said to resemble two triangles placed base to base, the equilateral triangle forming the anterior part of the insect and the isosceles triangle forming its posterior part.

Cuncerning the harmful species volumes have been written. They are migratory in habit, and their migrations are undertaken in search of food. Adults and immature forms of these migratory Locusts will travel in countless thousands from district to district. While on the wing they darken the sky; on the ground nothing but the seething masses of their bodies can be 
seen; when they have passed, vegetation is destroyed over the whole area, not a green blade remains; no human army retreating before its foes could lay bare the land more completely. "Voet-gangers," or "footgoers," as the immature Locusts are called in South Africa, are equally destructive. True, they have no wings, therefore they cannot fly, but they often migrate on foot, despite their disability. South Africa, North Africa, and the Mediterranean region, are the districts most affected by Locust migrations. Formerly the vegetation of the Mississippi Valley was destroyed by migrations of the Rocky Mountain Locust, Melanoplus spretus, whose breeding-grounds were situated on the elevated plains of the Rocky Mountains. All the migratory species are provided with large wings, by means of which they can make a peculiar crackling sound at will. The non-migratory species can always be distinguished by their attenuated wings-the North American Dictyophorus reticulatus, an ungainly, smallwinged creature, is an example; on the other hand, by no means all of the larger-winged species are in the habit of making migrations.

The life-histories of all the Acridiidae are very similar. The females lay their eggs in masses, below the surface of the ground, and each egg-mass is covered with a sticky semi-fluid excretion, which soon hardens and forms a capsule protecting the eggs. The larvæ emerge in the spring, and, by a series of moults, pass through the nymph to the adult stage. 


\section{EUPLEXOPTERA, EMBIOPTERA, PSOCOPTERA, THYSANOPTERA, RHYNCHOTA}

\section{Order Euplexoptera, or Earwigs.}

THE order includes a single family-

ForFICULID Æ.-Tegmina short; wings, when present, large and ingeniously folded when at rest; abdomen terminated by a pair of forceps.

Everyone knows the Earwig, but, despite the fact that it is so common, there are some startling discrepancies and differences of opinion concerning its habits. This is by no means an uncommon happening; very little was known of the ubiquitous House-fly till rather less than ten years ago, when attention was drawn to its insanitary habits.

The common British Earwig, Forficula auricularia, is widely distributed over the world. How it came by its popular name no one seems to know. It is commonly supposed that Earwigs are in the habit of entering the ears of human beings, with dire results. That such a happening has never taken place it would be foolish to deny; to state that it is the usual practice of Earwigs would be equally absurd. These insects are in the habit of entering any dark cavity they can find, for they are nocturnal in their habits. In their search for shelter 
they might enter the human ear, but their doing so would be purely accidental. Other authorities state that the wing of this creature, wlien unfolded, is much like an ear, and that is the reason for its name. The fact remains that all over Europe and in America the insect has popular names relating to an ear.

On the subject of its food, opinions are also divided; one party holds that the Earwig is a destructive insect, doing much harm to vegetation; by the other party it is said to be a carnivorous insect, feeding upon harmful creatures. This much is known of its life-history : Its eggs are laid in batches, and the mother insect takes the greatest care of them, moving them from one place to another wherever she deems best for them, and brooding over them between whiles. The appearance of the larvæ, which are similar to their parents, though smaller and paler coloured, is the signal for the female Earwig to leave her progeny to their own devices.

Another British species, Labia minor, is also quite common, and, unlike auricularia, it flies by day.

Many of the exotic Forficulida are large insectslarge, that is, compared with our native species; the peculiar forceps with which their bodies terminate is the most striking and constant character of these insects. The forceps of the different species differ considerably in form: some are stout and nearly straight, others very slender and much curved, and there is every intermediate stage. Their precise use is open to some doubt; they are often opened in a threatening manner in the presence of danger, but in most species the forceps are useless for defence. Some species undoubtedly use these organs to assist in folding their 
wings. The latter are large, and when not in use are packed into a small space by fanwise folds followed by a couple of transverse folds. Several species of Earwig, however, are wingless; why, then, do these insects, having no wings, possess a pair of forceps? The question is one which must be left unanswered for the moment. The wingless forms follow the rule usual in the family, that the forceps of the females are smaller and more simple than those of the males.

\section{Order Embioptera.}

Емвішдж.-Head large; antennæ slender; its joints varying in number from eleven to thirty; tarsi threejointed; all four wings of equal size; metamorphosis incomplete.

These insects are closely allied to the Termitida, and have the appearance of being small individuals of that family. Little is known of them, though they appear to be fairly widely distributed. The brick-red Egyptian species, Embia savignyi, is one of the best known of the Embiids.

\section{Order Psocoptera.}

Psocidæ.-Head very large; long, slender, threadlike antennæ; tarsi with two to three joints; hind-wings smaller than fore-wings; metamorphosis incomplete.

Some species of this order frequent old books and papers, probably feeding upon the starchy materials in the bindings-these insects are popularly known as Book Lice; other species dwell out of doors, on old lichen-covered trees or on leaves, living together in colonies. 
The Psocids are the non-house-frequenting members of the order. Some of them are so minute that they would be difficult to observe were they not in the habit of collecting together in clusters. The twospotted Psocus, P. bipunctatus, is a common British species, dull yellow in colour and of about a quarter of an inch in wing-span; it frequents the stems of old apple-trees.

Howard gives an interesting account of $P$. venosus, a common American species: "It is small and smokybrown in colour, and is seen upon the trunks of trees in flocks numbering from a dozen to forty or fifty individuals. They feed in companies and browse upon the lichens, which they cleanly remove from the bark, leaving a clear space behind them. The colonies consist of one or more families, and include individuals of all ages, the wingless young herding with the adult insects. The adults, though winged, do not readily take to flight. When alarmed, the whole troop huddles together, apparently for mutual protection, like sheep, but when seized with a sudden panic they scatter in every direction and run rapidly over the bark, their colour harmonizing so closely with that of the bark that they are not easily distinguished. Soon after they reassemble and begin to eat the lichens.

" The eggs are oval, glistening white, and are laid upon the bark in batches of fifteen to thirty, deposited on end in several rows and each cluster is protected by an oval, convex shield of gnawed-up wood which adheres closely to the eggs. The females brood over the eggs, see that they are not disturbed, and, when they hatch, lead the young ones forth to pasture." 
Psocus citricola, living on orange-leaves, has very similar habits.

Atropid w.--Similar to Psocida, but wingless.

All the Book Lice are small, almost colourless insects. Our common Atropos pulsatoria is only a twentieth of an inch in length, and must be known to most of our readers, though it may not have been recognized, as it runs rapidly over the leaves of old books or about old furniture.

There is little reliable information concerning these insects, but they are certainly injurious in libraries, museums, etc.

Order Thysanoptera, Fringe-Winged Insects.

Very minute insects with mouth-parts intermediate between a biting and a sucking mouth; four wings, when present, fringed with hairs, but may be much reduced or absent; two-jointed tarsi terminated by a bladder-like vesicle.

These minute insects, which are generally termed Thrips, average about one-thirtieth of an inch in length. The largest species is the Australian Idolothrips spectrum, and it only attains a length of one-third of an inch.

Thrips have received scant attention from entomologists; rather more than one hundred and fifty species are known, but it is surmised that there are probably a vast number of species as yet undescribed. Although neglected as an order, these minute insects are by no means devoid of interest. Their mouth-parts are peculiar in that they cannot be described as true sucking mouths, nor yet as true biting mouths. They are still more unusual on account of the fact that they 
are not the same on either side. This bilateral asymmetry is very unusual in insects.

The wings of these tiny creatures are very characteristic; the fore and hind wings are always placed wide apart, and both pairs are always fringed with hairs. They are very fragile, and often the fore and hind wings are of different colours and texture. The very curious feet resemble little bladders, membranous and protrusible structures which probably give their owners a better hold on smooth leaf-surfaces than would claws

Metamorphosis is striking, and is intermediate between complete and incomplete. The larvæ resemble the adults fairly closely and precisely as regards their mouth-parts. The nymphs are not active, as is usual with nymphs, but are enclosed in a skin and take no food.

The majority of these insects appear to feed upon the pollen of flowers; some of them, however, are notorious pests. The Pea Thrips, Kakothrips robustus, lays its eggs in pea and bean flowers, upon the stamens or young pods. Both larvæ and adults are injurious, and in bad seasons no pods are formed. The Orange Thrips, Euthrips citri, causes a considerable amount of trouble in California by causing white marks on the fruit, which, while not actually injurious to the oranges, lowers their market value. In the same State the Pear Thrips, Euthrips pyri, is a very serious pest. It is particularly partial to pears, prunes, and cherries, and injures them by passing to the tenderest parts of the buds and killing them.

Some species of Thrips, like certain species of Aphis, spend part of their time on one food-plant and part on another. Such an insect is the Flax Thrips, Thrips 
lini, which, after taking up its abode on the roots of flax for a period, migrates later to other food-plants. In many respects these insects have much in common with Aphids; for instance, there are winged and wingless females, and also parthenogenesis is of common occurrence.

\section{Order Rhynchota, or Bugs.}

The Rhynchota are all provided with hard, horny, jointed sucking beaks, usually with two pairs of wings, and their metamorphosis is incomplete. The young resemble the adults, more or less, at birth, and with each successive moult the similarity becomes greater. The order is divided into two suborders-(1) Heteroptera, possessing fore-wings thickened at the base and membranous at the tips, also with beaks inserted at the front part of the head; (2) Homoptera, possessing uniformly thickened fore-wings and beaks inserted at the hinder part of the head.

The number of species in the order is very great, more than twenty thousand being known to science. In point of age they were amongst the earliest insects to appear on this earth, their fossil remains being found in Palæozoic rocks. Popularly known as "Bugs," though in America many insects of other orders are so named, the Rhynchota are of the greatest economic importance. A large number of them, such as the Aphids or Green-flies, the Coccids or Scale insects, the Aleurodids or White-flies, and the Psyllids or Jumping Plant Lice, are exceedingly destructive to vegetation. There is, in fact, no single family of insects containing a greater number of injurious species than the Coccidae. 
Some "Bugs" are carnivorous and prey upon other insects; of these flesh-eaters, the Reduviids are the best known. In the main, however, the order is comprised of enemies of the human race, so much so that one eminent entomologist has stated that " if anything were to exterminate the enemies of Hemiptera, we ourselves should probably be starved in the course of a few months."

There is one peculiarity of the Heteroptera, or true "Bugs," which soon makes itself apparent to the student of these insects. Many of them are possessed of a peculiar and characteristic odour. The Bed Bug has a decidedly disagreeable perfume. "Others smell like very ripe or overripe fruit, especially pears, while in some Coccidce the odour is aromatic and in others it is spicy like cinnamon." In every case the odour arises from a volatile oil which is exuded from orifices known as "stink-glands;" its object is probably protective, for few enemies would relish an evil-smelling Bug.

\section{Suborder Heteroptera.}

The members of this suborder dwell either upon land, upon water, or under water. The suborder contains two series-(a) Gymnocerata, with conspicuous antennæ; and (b) Cryptocerata, with hidden, inconspicuous antennæ. Curiously enough, the purely aquatic forms all belong to the latter series, and the dwellers on land and water to the former.

\section{Series Gymnocerata.}

Pentatomma may be recognized by the fact that the bases of their five-jointed antennæ are not visible 
from above, the scutellum is large-at least half as long as the abdomen, often larger-the beak is fourjointed, and two ocelli are always present.

The family is the largest of the Heteroptera, and the species are as varied in form and size as in colouring. Many are as brilliantly attired as the most gaudy tropical Beetles; some are sombre in the extreme; others, again, are so delicately tinted that their appearance soon changes after death. For the most part, they are plant-feeders, but some appear to eat vegetable and animal fare impartially.

Although the family is a large one, very little is known concerning the habits and life-histories of the species of which it is comprised. There are nearly forty species of Pentatomidoe in Britain, and one, Acanthosoma griseum, is interesting in that it is one of the few insects known to mother its young.

In the United States, the Harlequin Cabbage Bug, Murgantia histrionica, Hahn, is a serious pest of cruciferous crops. The insect goes by the curious popular name of the "Abe Lincoln Bug" in Georgia, and the " Third Party Bug" in Texas.

The green Pentatomids of the genus Nezara, common in many parts of the world, are known to feed upon either plants or insects as opportunity offers.

COREID E. Scutellum less than half the length of the abdomen; beak and antennæ four-jointed, the latter inserted on the sides of the head; the membranous portion of the wing-cases with a number of forked, longitudinal veins.

This is another large family of which only about two dozen species occur in Britain. In the main, the 
Coreidce are of sombre hue, though many species atone for their lack of brilliant colouring by their eccentricity of form. In some species the antennæ bear flattened dilatations, and in many the femora or tibiæ of the hind-legs are either much swollen, armed with formidable spines, or are ornamented with flattened, disc-like structures, brightly coloured and of unknown use. The South American Diactor bilineatus has leaf-like hind tibiæ. In Leptoglossus phyllopus we see the same abnormality, less highly developed. Metapodius femoratus has thickened spiny femora, but of all the Coreidoe none is more curious than the South European Phyllomorpha laciniata. The back of this creature forms a hollow, by reason of the upturned edges of its body In the hollow of its back the male carries his mate's eggs, held in place by numerous spines. None of the British species exhibit any peculiarities of structure.

The Coreidae are all plant-feeders, and many of them are exceedingly destructive to crops. The American "Squash Bug," Anasa tristis, De Geer, is a noted pest of Cucurbitacece.

LYGAID E. - The characters of this family are very similar to those of the Coreida. The Lygæids, however, may be distinguished by the fact that the antennæ are inserted "well down on the sides of the head," whilst the veins, on the membranous portion of the wing-cases, are unbranched and four or five in number. This is another large family with more than fifty British species, though most of our native forms are small and drab. The Lygæids are not so ornate as the Pentatomids, or of such peculiar structure as many of the Coreids. The prevailing colour of the family is black 
relieved with yellow or red. Like the Coreids, all the species are plant-feeders; some of them are among the most notorious of crop pests. The Chinch Bug, Blissus leucopterus, Say., of Northern America and the West Indies, is exceedingly injurious to cereals, especially to maize. The insects collect in thousands on the stems of their food-plants, and, by sucking their juices, cause them to wilt. Having destroyed one crop, they migrate to another, not by flying, though they possess the power of flight, but by walking. In certain favourable seasons the Chinch Bugs are kept in check by a fungoid disease which kills them off in large numbers.

PYrRHOCORID a are very similar to Lygceida, but whereas the latter have ocelli and unbranched wingveins, the members of this family lack ocelli, and the membranous portions of their wings show more than six forked, longitudinal veins.

The family is much smaller than any of the three we have already mentioned, and there is but one British species, Pyrrhocorus apterus, and it is by no means common. For the most part, Pyrrhocorida are tropical or subtropical. These insects are plant-feeders, and many of them are of economic importance, especially the Cotton-Stainers, Dysdercus spp., and the Lesser Cotton-Stainers, Oxycarenus spp. Of the former we may take Dysdercus suturellus, H. Schf., as our type. The insect is common in the Southern States of America and in the West Indies. It is doubly injurious, for not only does it feed upon the juices of oranges, causing the fruit to decay where its beak pierces the rind, but it feeds upon cotton bolls. The Cotton-Stainer has earned its title from its habit of dyeing the cotton in 
the bolls with its yellow excretions. "Experiments have been made with this insect looking toward its use as a dye, and the whole substance of the insect can be converted into a rich orange-yellow dye, which can readily be fixed on woollens or silk by the alum mordant liquor."

The Lesser Cotton-Stainers, Oxycarenus spp., are natives of Africa and India. They, apparently, only attack cotton bolls which have already been damaged by other insects. When they do enter the bolls, however, they destroy large numbers of unripe seeds. Unlike the true Cotton-Stainers, these insects do not damage the cotton with their excrement, but become crushed during ginning, thereby staining the fibres. This contretemps may be avoided by spreading the cotton in the sun before ginning, when the insects will take to flight.

TINGIDA.-Like the Pyrrhocorido, they have no ocelli, their fore-wings are longer than the abdomen, the penultimate antennal joint is much elongated and the last joint is knobbed. The tarsi are two-jointed.

The Tingids are known in America as "Lace Bugs," and for once the title is apt. For the most part delicately formed insects, many of them are so beautifully sculptured and so bizarre in appearance that they form interesting objects when magnified. They are well represented in Britain, for of a small family no less than a score are native to this country. Our commonest species is Tingis pyri, destructive to pear-trees. All are plant-feeders; some dwell in malformations of flowers; others assemble in such numbers on the leaves of certain trees and suck the plant juices so vigorously 
as to cause a general wilting to take place. Their eggs are usually laid on the leaves of their food-plants; little barrel-shaped structures they are, and so firmly affixed to the leaf that it is impossible to remove them without lamage to their support.

ARADID \&.-Flat, broad insects, without ocelli; their ving-cases are shorter and narrower than the abdomen. Often deeply sculptured, and always of a brown or reddish-brown colour.

These Bark Bugs cannot readily be mistaken for any other insects; they are so abnormally flat that one noted entomologist has said that they look as though they had been stepped upon. There is good reason for their flatness and their drab colour, for they live beneath bark and feed upon the fungi which they find there. Being flat, they can easily crawl into the narrowest chinks, and their brown colour renders them less easily observed. Only five species occur in Britain.

HYDROMETRID\&.-Antennæ four-jointed; tarsi twojointed; wings often absent or possessing no membranous part; legs often greatly elongated; body often pubescent.

The Hydrometridae are of interest on account of their habit of living on the surface of water. In form they are exceedingly diverse. A common British member of the family, Hydrometra stagnorum, popularly known as the Water-Measurer or, erroneously, as the Water Gnat-it is not related to the gnats-is a creature worthy of study. Its body is narrow and stick-like, its head much elongated, and its wings are never developed. Though by the aid of its long, slender legs it is enabled to walk on the surface of the water, 
holding its body aloft, should misfortune occur and the creature become wet, it will drown more readily than many purely terrestrial insects.

Another British insect, Velia currens, the Water Cricket-it is not allied to the Crickets-is also perfectly at home on the surface of the water, and the two longitudinal orange stripes which ornament its back render it somewhat conspicuous.

Members of the genus Gerris, common on our ponds, differ in habit from the two preceding forms, in that they do not spend all their time on the surface of the water, but often dive. The pubescence with which their bodies are clothed prevents them from getting wet.

Halobates spp. are ocean-dwellers, many of them having been found on the surface of the ocean, far from land. The family contains many aberrant forms, and all of them, so far as is known, feed upon animal matter, though probably few hunt and capture living prey.

HeNICOCEPHALIDA are distinguished by a globular swelling of the head behind the eyes, very short beak, and much-veined, wholly membranous fore-wings.

There is no British representative of this order; in fact, only about a dozen, though widely distributed, species are known. "A Tasmanian species dances in the air after the fashion of Midges or May-flies, and dispenses an agreeable musk-like odour."

REDUVIID e very closely resemble Henicocephatida, but there is no globular swelling behind the eyes; beak short and forming a loop below the head when at rest; tarsi three-jointed.

The Reduviids are as variable in form as the Hydro- 
metrida, and far more variable in colour. All of them are predaceous, even to the extent of attacking man; on this account they have been named "Assassin," "Pirate," and "Cannibal" Bugs. The family is a large, important, and widely distributed one.

The "Blood-Sucking Cone Nose," Conorhinus sanguisuga, sometimes called the Giant Bed Bug-though the Bed Bug is not a Reduviid-normally lives in the nests of field mice. In the South-Western States of America it enters human dwellings and sucks the blood of the inmates, causing painful, festering sores.

Another species, Reduvius personatus, which occurs in Britain, may be called a friend of mankind, for it preys upon Bed Bugs and Cockroaches. The miniature forms of this insect, and of closely allied species, have the curious habit of covering their backs with any portable matter that may be at hand. The house-dwellers use dust, and some of the outdoor species make use of lichen.

All the members of the subfamily Emesidae are delicate, elongated, long-legged insects, resembling miniature Stick insects. Their movements are slow, and they have the common habit of raising and lowering their bodies as they progress. "Their front legs are peculiarly formed for capturing and holding their prey, and have long coxæ, like Mantis, so that these insects are commonly mistaken for small or young Mantises, from which their sucking proboscis at once distinguishes them."

Certain Reduviids exhibit remarkable mimicry of other insects. "According to Seitz, there is found on the Corcovado in Brazil a Reduviid that exactly re- 

PLATE IX

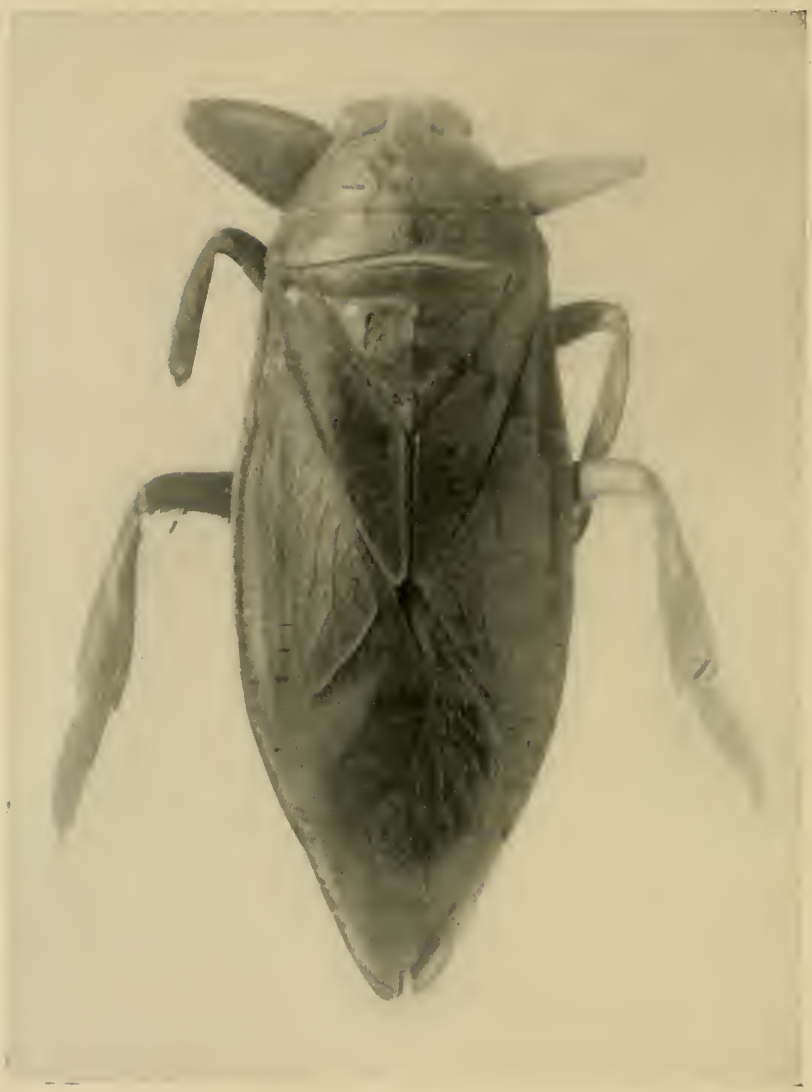

GIANT WATER BUG (BELOSTOMA SP.) 
sembles one of the dark stinging-wasps of the genus Pepsis, and the bug makes the same movements as the wasp does, though these are of a kind quite different to those of ordinary bugs." One of our native species, Nabis lativentris, in its immature stages, closely mimics an Ant. Like many other Ant-mimiking Bugs, Nabis lives amongst the insects it so closely resembles, thereby in all probability preying upon them the more easily. It is a remarkable fact that the adult Nabis in no wise resembles an Ant.

CIMICID $\approx$ have no ocelli on their short, broad heads; wing-cases rudimentary; three-jointed tarsi; and a beak which fits into a groove under the head.

The family comprises a dozen species, of which the cosmopolitan Bed Bug, Cimex lectularius, L., is the best known. The Bed Bug is a flat-bodied, wingless creature, parasitic upon man. In Elizabethan times it was common in every house in the country; now the abolishment of the four-poster bed, a favourite haunt of the insect, and greater attention to cleanliness have combined to oust this pest from our dwellings. Like all parasite insects, Bed Bugs can exist for extraordinarily lengthy periods without their normal foodblood. When they pierce the human skin they do not secrete any poison, but their bite is painful. They are suspected of carrying recurrent fever and leprosy.

Man is not the only enemy of this loathsome insect; Reduvius personatus is its inveterate foe; several species of Ants and, in addition, Cockroaches prey upon it.

CAPSID $\&$ have relatively large wings and wing-cases, the latter with only two cells (sometimes only one) in the membranous portion. The four-jointed antennæ have 
very long second joints, and the two basal joints are plainly stouter than the two end joints. Tarsi three-jointed.

This family is probably the largest of all the Rhynchota, and there are nearly two hundred species in Britain. Most of them are plant-feeders, though some few attack and feed upon other insects, notably Camptobrochis grandis, which preys upon the Elm-Leaf Beetle, Galerucella luteola, an American forestry pest.

Poecilocapsus lineatus, F., the Four-Lined Leaf Bug, is a common American pest of garden plants, such as currants and gooseberries. It is interesting on account of its method of oviposition, a method which is common to many Capsids. Longitudinal slits are made by the female in the stem of some food-plant. Each slit, which may be an eighth of an inch in length, is so deep that it passes half way to the pith. From two to fourteen eggs are deposited, side by side, in every slit.

Capsids of the genus Helopeltis are very destructive to tea-plants in India.

\section{Series Cryptocerata.}

NEPID \&.-The end of the abdomen is provided with two grooved filaments, forming a respiratory tube; the long, raptorial front legs are affixed to the forward end of the prothorax.

There are only two, widely distributed, genera in the family, and both are represented in Britain. The genus Nepa comprises flat, oval forms, whilst all the members of the genus Ranatra are elongate. The filamentous appendages of the abdomen, so characteristic of the family, are important and interesting. Each filament is grooved in such a manner that when brought into 

PLATE $X$

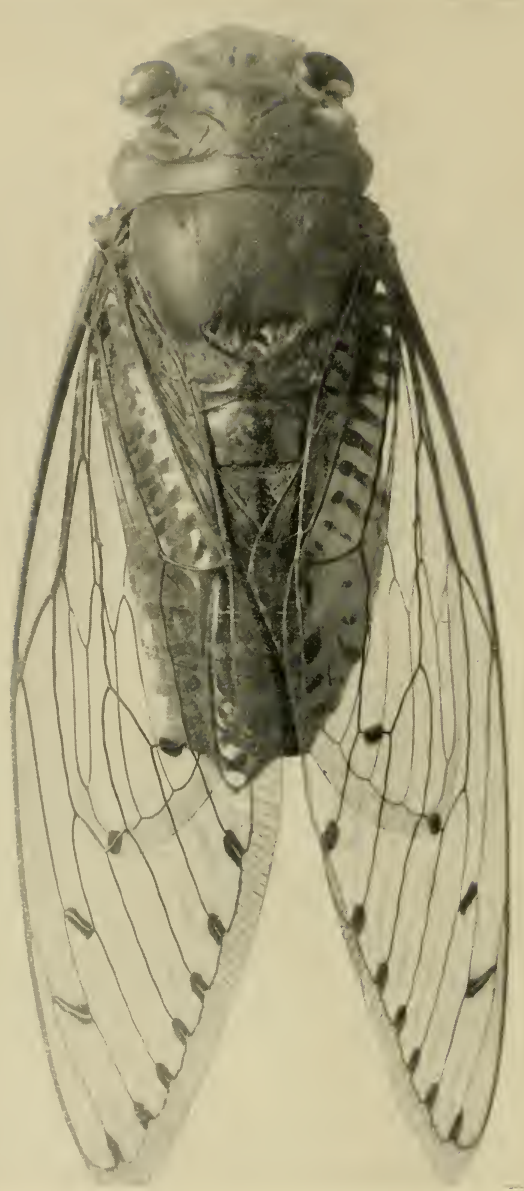

CICADA 
contact with its neighbour the two form a hollow tube, along which air passes to the respiratory apparatus within the insect's abdomen.

Nepa cinerea, L., the Water Scorpion, is a common inmate of our stagnant ponds. It is not easy to detect; in appearance it resembles a small dead leaf as it floats on the surface of the water. On the muddy bed of its home where it seeks its prey it is still more difficult to observe. A sluggish creature, it rarely flies, though provided with wings. Prey, in the form of small waterfrequenting creatures, is seized and held by the forelegs, which are admirably adapted for the purpose. Along the inner side of each of the femora on the forelegs there runs a deep groove; into this the tibiæ fit much after the manner of the blade of a pocket-knife in its handle. The inner edges of the tibiæ are sharp, and there is little chance of any creature escaping when once firmly in the grasp of the "Water Scorpion." The eggs of Nepa are peculiar. They are inserted into the stems of water-plants, much in the same manner as are those of the Capsids. The body of the egg remains buried in the plant tissues, but from its apex there project seven thread-like protuberances, which are possibly connected with the aëration of the egg.

Ranatra linearis is not nearly so common in Britain as its relative Nepa. It is popularly known as the Water Stick insect, and is a much more active creature than the Water Scorpion, being frequently observed on the wing. In other respects the habits of the two insects are very similar, but the eggs of Ranatra only possess two thread-like protuberances, instead of the seven invariably found in Nepa. 
BeLostomide.-Hind-legs adapted for swimming; no ocelli or respiratory filaments.

This is a small family of aquatic Bugs, and no species occur in this country. Some of the South American species are among the largest of insects, measuring nearly five inches in length. They are predatory, and the larger species prey upon fishes, which they catch in their powerful, grasping fore-legs. They are strong fliers, and readily take to wing. All of them are mudcoloured, unattractive-looking creatures.

The genus Zaitha comprises some active, free-swimming species. It is the habit of these creatures to carry their eggs from place to place, firmly cemented to their backs with some insoluble substance. For a long time it was thought that the females were thus solicitous of their progeny, but later researches have shown that it is the male who obligingly performs the duties of nurse. At times his burden becomes irksome to him, and then he does not hesitate to attempt to relieve himself of his load; his efforts, however, are usually unavailing. These eggs, by the way, are looked upon as a delicacy by gourmets in some parts of South America.

NотоNECTIж.-Fore-tarsi with two claws; head inserted into prothorax.

These predaceous aquatic Bugs are commonly known as " Water Boatmen." They all swim upon their backs, propelling themselves by means of their long hind-legs, which they use as oars. Notonecta glauca, a denizen of nearly every stagnant pond, is an active swimmer, strong on the wing, and exceedingly rapacious. When these Water Boatmen dive beneath the surface of the water, they carry with them a film of air which renders 


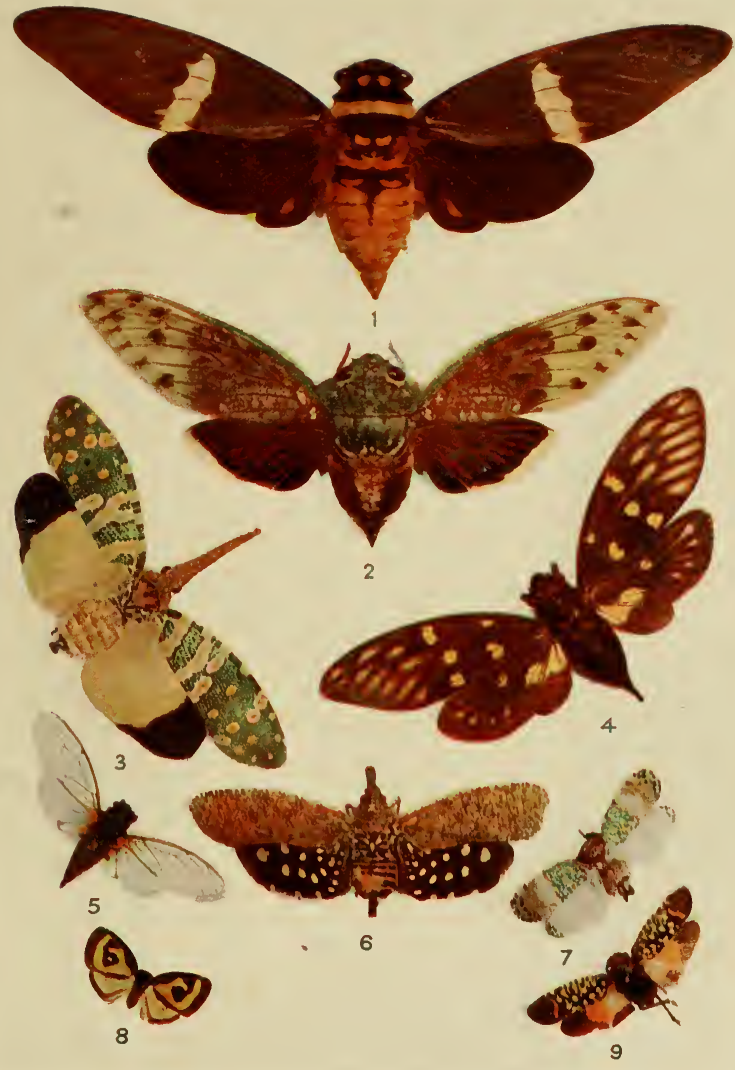

A GROUP OF HONIOPTERA

Nos. 1, 2, 4 and 5 are Cicadas, the last being the only British species; the other figures represent I:ulgoridx, No. 3 being the so-called Candle fly; Nos, 7,8 and 9 are Flatidx. 

them buoyant, so much so that they are compelled to anchor themselves to some water-plant, lest they should rise, willy-nilly, to the surface.

Plea minutissima, another British member of the family, is a minute, inactive creature which dwells in the muddy beds of some ponds.

CorIXIDж.-Closely allied to Notonectidoe, but the fore-tarsi have no claws, being adapted for swimming, and the head overlaps the prothorax.

These insects resemble the Water Boatmen in habits, with the important difference that they swim in the normal manner and not upside down; moreover, they are not so buoyant in the water as the Boatmen. The commonest of the many British species is Corixa geoffroyi a brown, yellow-spotted creature, which retires to the mud, in which it buries itself, on cold days. Sigara minutissima is the sole representative of another British genus.

"The eggs of two Mexican species (Corixa mercenaria and $C$. femorata) are laid in enormous numbers in lakes near the city of Mexico, and are made into cakes with meal and are eaten by the Indians and half-breeds. They are said to have an agreeable acid flavour. 'I ate some once, but it was a stale museum specimen and had anything but a pleasant taste. These Mexican species are imported into England by the ton as food for game and song birds, poultry, and fish. Kirkaldy has computed that one ton contains $25,000,000$ of these insects."

\section{SUBORDER HoMOPTERA.}

Cicadma.-Between the compound eyes there are three ocelli arranged in a triangle; antennæ, except for 
the basal joint, are minute and bristle-like; front femora thickened and toothed.

Most of the Cicadas are large, showy insects, with membranous, prominently veined wings. Some of them are brilliantly coloured, vieing with the tropical Butterflies. Nearly all are inhabitants of the warmer parts of the earth; there is one British species.

The two outstanding features of this family are the well-developed vocal powers of the males of practically every species, and the extraordinarily protracted lifecycle of one species.

There are no insects capable of making more noisesong some would call it-than the Cicadas. "A curious difference of opinion prevails as to whether their song is agreeable or not; in some countries they are kept in cages, while in others they are considered a nuisance. The Greeks are said to have decided in favour of their performances, the Latins against them." An American entomologist, describing the "song " of a native Cicada, says: "The general noise, on approaching the infested woods, is a combination of that of a distant threshingmachine and a distant frog-pond. That which they make when disturbed mimics a nest of young snakes or young birds under similar circumstances-a sort of scream. They can also produce a chirp somewhat like that of a cricket, and a very loud, shrill screech, prolonged for fifteen or twenty seconds, and gradually increasing in force then decreasing."

The song is produced by the rapid vibration of certain complex vocal organs, which are situated on either side of the base of the male abdomen. The f males either have no vocal organs or structures of so 
PLATE XII

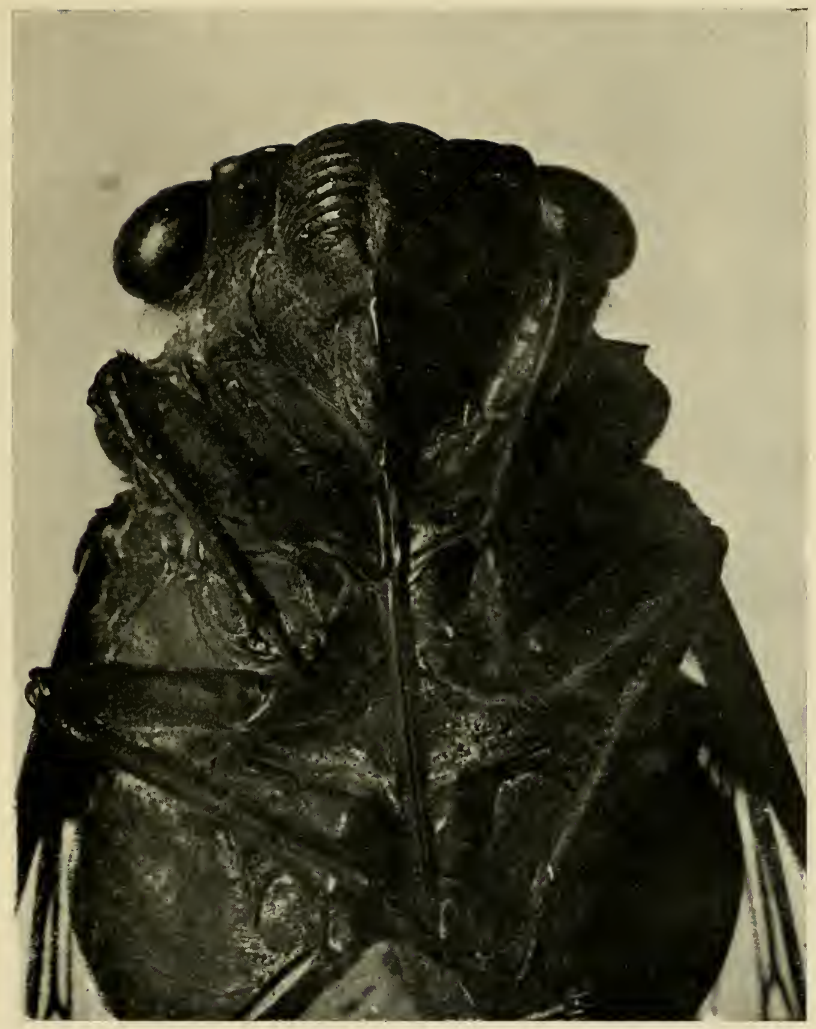

HEAD OF CICADA, UNDER-SIDE, HIGHLY MAGNIFIED 

rudimentary a nature that they are incapable of emitting a sound. This latter fact led the Greek poet Xenarchus - evidently a married man-to write, "Happy the Cicadas' lives, for they all have voiceless wives." It is probable that the vocal efforts of the males are intended to attract the females.

One of the most romantic of life-histories in all the insect world belongs to the Periodical Cicada, Cicado septendecim, L., sometimes wrongly named the Seventeen Year Old Locust.

The females are armed with powerful ovipositors, and by their aid the eggs, in enormous quantities, are deposited in the twigs and young stems of trees, causing, needless to say, considerable damage. When the larvæ emerge from the eggs, they at once fall to the ground and burrow beneath its surface, constructing for themselves little subterranean chambers. For seventeen long years the larvæ live below ground without seeing the light of day. They move but little and slowly, and the nature of their food is uncertain. Four moults are passed through before the nymph stage is reached, then a general migration to the surface of the soil takes place. Sometimes the nymph at once ascends the neighbouring trees; sometimes they build little earthen chimneys on the surface of the soil, in which they await a favourable opportunity to show themselves. In any event, they reach the near-by trees sooner or later, the nymphal skin splits, the adults emerge in their hundreds of thousands, and the air resounds with the cries of the males. The arrival of the adult Cicadas is the signal for the advent of hosts of enemies; even the English sparrow, a typical grain- 
eater, cannot resist a meal of a plump Cicada. Their periodical visitations, their innumerable enemies, and the fact that the whole aspect of the earth's surface may have changed, during the seventeen years of larval life, all combine to render the extinction of this interesting insect merely a question of time. The females which survive their short stay upon earth lose no time in mating and depositing their eggs; in a few weeks the larvæ have travelled to their subterranean dwellings, and the district knows the periodical Cicada no more till the passage of seventeen years. There is a race, however, which only spends thirteen years below ground.

The American Bureau of Entomology has mapped out the sites of all the broods in the continent. "The largest of the North-Eastern broods made its last appearance in 1902, and is due again in 1919."

0 FULGORIDE.-Very variable. The antennæ and ocelli (usually two) placed beneath the eyes; the former usually two-jointed, terminated by a filament.

A large family of very varied forms, both in size and general structure. Some of these insects of the subfamily Flatidoe are remarkably like Lepidoptera at a casual glance; others have the front of the head produced into an enormous snout or a large bulbous growth, which early travellers wrongly asserted to be luminous. Members of the tropical American genus Phenax, and notably $P$. auricoma, are remarkable on account of the relatively enormous masses of waxy threads which they secrete. $\vee$ In auricoma these threads are sometimes six inches long and harbour Lepidopterous larvæ which devour the wax, being transported from place to place 
PLATE XIII

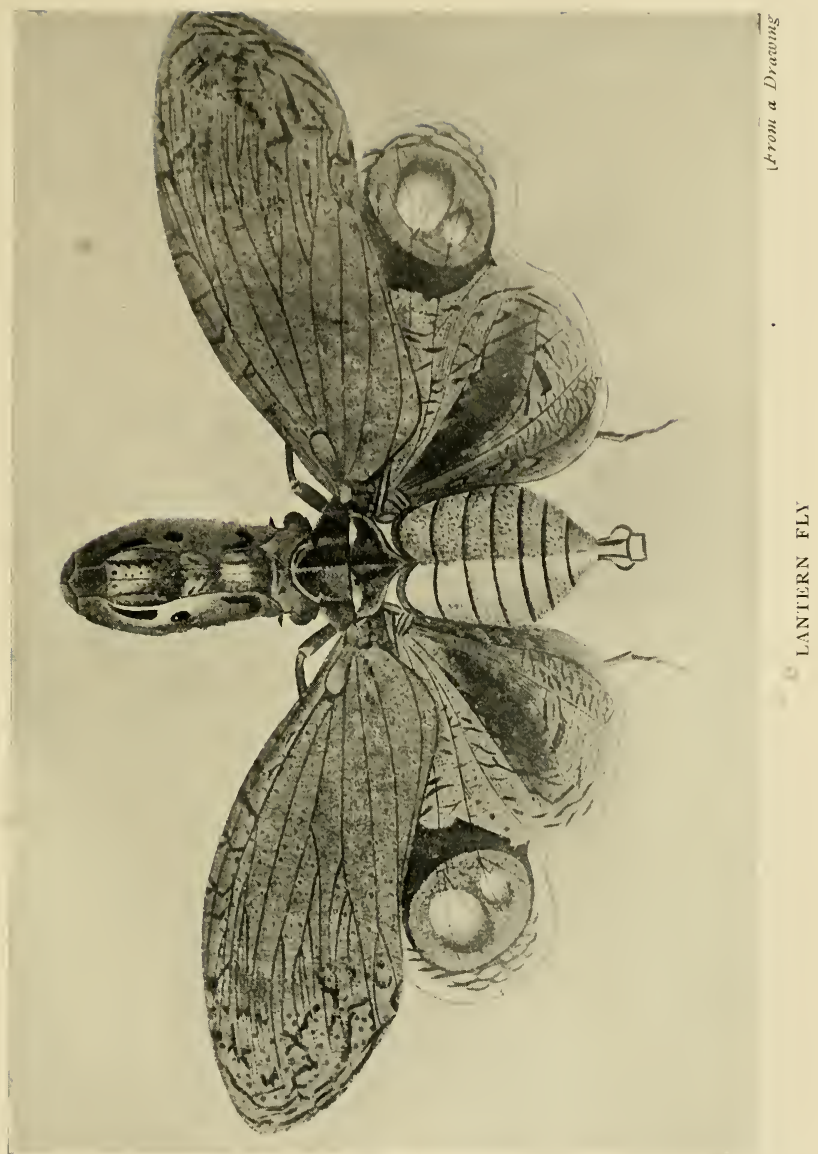



the while by the accommodating Bug. Of what use this wax may be to the Fulgorids is unknown, but in China the secretion from a native Bug is made into candles.

About seventy species of Fulgoridce are known in Britain; all, British and exotic, are plant-feeders.

- Membracide.-Prothorax prolonged backwards into a horn or shield over the abdomen; two ocelli between the eyes, and the antennæ inserted in front of these organs.

Of all insects, the Membracids are the most bizarre in form. "Nature must have been in a joking mood when tree-hoppers (Membracido) were developed." They are mainly tropical, only two species being known in Britain, and they are all relatively small in size and of sombre coloration.

It is probable that the quaint forms of the majority of Membracids serve for their protection; many of them very closely resemble the structures of various parts of the plants, such as seeds, thorns, etc., on which they live. All of them deposit their eggs in slits made in some favoured plant by the ovipositor of the female. This habit causes them to be looked upon as pests by gardeners and farmers.

- CERcopid $2 .-T w o$ ocelli, placed on the vertex; antennæ inserted in front of and between the eyes; prothorax not prolonged above the abdomen; hindtibiæ with one or two stout teeth below.

This is the family of "Frog-Hoppers" or "CuckooSpit" insects. They are so called because, in the first place, they all have the power of leaping to considerable distances, and, in the second place, the larvæ have a habit of surrounding themselves with a frothy secretion. 
Our native Cuckoo-Spit insect, Philoenus spumarius, is well known to everybody. The female deposits her eggs on plant-stems in autumn, and the young hatch in the spring. They at once proceed to dig their beaks deep into the tissues of the food-plant, and from the end of the abdomen a clear liquid exudes. By dint of violent agitation of the abdomen this liquid is beaten into a froth, which completely hides the larva. Although hidden, the position of the young insect is thus rendered more conspicuous, and certain Hymenoptera do not hesitate to drag him from his hiding-place to serve as food. "The phenomena known as weepingtrees are often due to Cercopida ; some of the species make such copious exudations of this kind that the drops have been compared to a shower of rain. In Madagascar it is said that ${ }^{\circ}$ Ptyelus gondoti exudes so much fluid that five or six dozen larvæ would about fill a quart vessel in an hour and a half. . . . In Ceylon the larva of Machorota guttigera construct; tubes fixed to the twigs of the tulip-tree, and from the tubes water is exuded drop by drop."

JASSm e.-Closely allied to Cercopida, from which they may be distinguished by the fact that their hind tibiæ are armed with numerous spines.

A large family of minute, fragile insects; all are vegetable-feeders, and it has been computed that frequently on an acre of pasturage there are about a million Jassids which consume as much, if not more, grass than a cow.

- Proconia undata, an American species, owing to its habit of ejecting a spray of liquid when disturbed, is also responsible for "weeping-tree" stories One of 

PLATE XIV

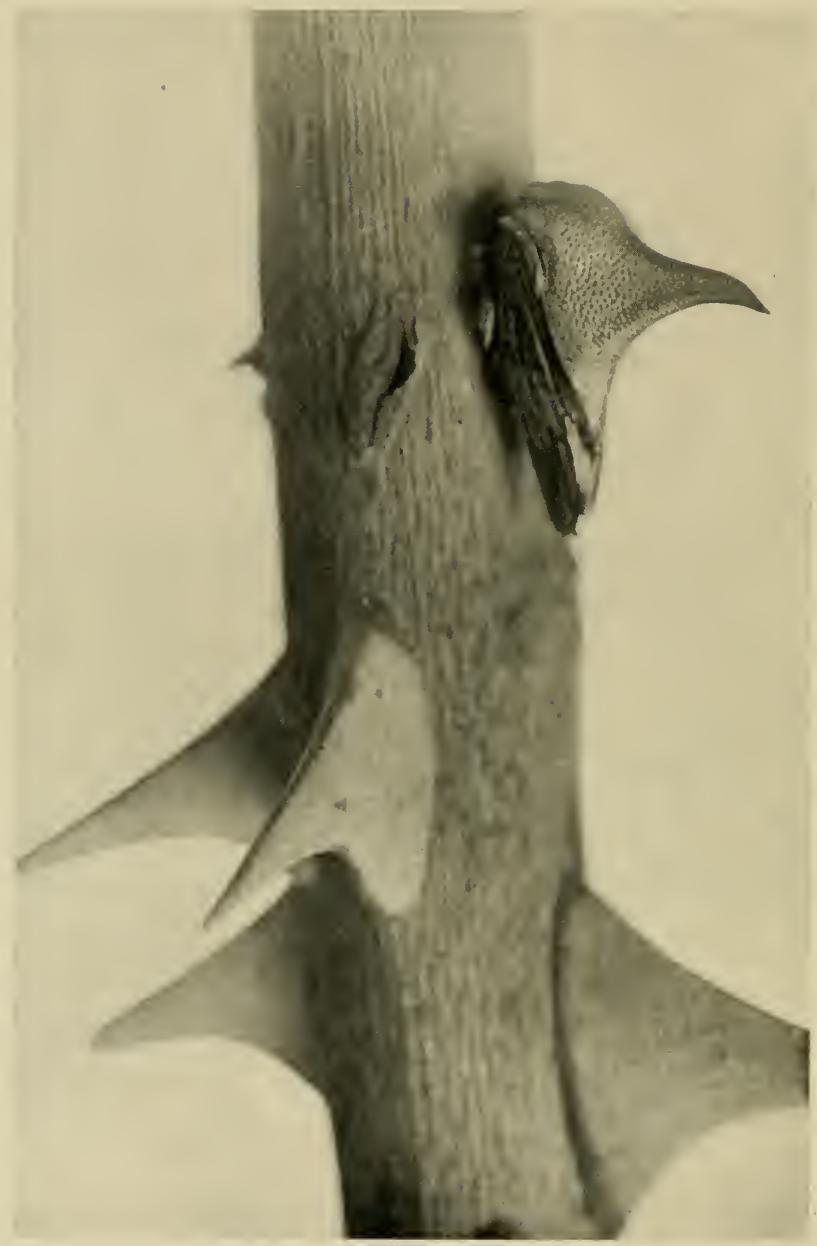

A MEMBRACID WHICH MIIICS A THORN 
these mysteries, which occurred in Texas some time ago, " set the State agog with various explanations of the phenomenon, ranging from the superstitious credence of the supernaturally inclined to the positive denial and derisive laughter of the constitutionally sceptical. It took a brave newspaper reporter to solve the mystery, since he alone dared to climb the tree and investigate."

Many of the Jassids, though so small and frail, are beautifully and brilliantly coloured.

Psylum e.-Ocelli three; antennæ with eight to ten joints; tarsi two-jointed and femora frequently swollen; wings transparent.

These minute insects much resemble minute Cicadas. They all possess the habit of jumping, and they all secrete a sweet, sugary liquid, known as honey-dew, which is much sought after by Ants, Bees, and Wasps. Some of them form galls, in which part of the life-cycle is passed.

About fifty species occur in Britain, of which the Pear-Tree Psylla, Psylla pyricola, is a well-known pest. The larval and pupal stages of these insects are strikingly unlike the adults.

APHIDж.-Winged or wingless; antennæ three to seven-jointed. A pair of tubes often project from the upper surface of the fifth abdominal segment. Tarsi two-jointed, legs long and slender.

The Aphids, or so-called Green-flies, are notorious plant pests, yet, withal, exceedingly interesting to the biologist by reason of their peculiarities of reproduction. So rapidly do they increase that Huxley computed that " the uninterrupted breeding of ten generations of Plant 
Lice from a single ancestor would produce a mass of organic matter equivalent to the bulk of five hundred millions of human beings, about the population of the Chinese Empire."

The most notorious members of the family are the Phylloxera, Phylloxera vastatrix, which, rather more than fifty years ago, destroyed more than a third of the French vineyards, and the Woolly Apple Aphis, Schizoneura lanigera, a well-known pest wherever apples are grown.

For a complete account of the reproduction of Greenfly readers must refer to the larger textbooks; space forbids more than a brief survey in these pages. From the winter egg, which is deposited on a food-plant, an individual arises which quickly, and without pairing, produces living young. Its progeny do likewise, with the result that, the egg stage being omitted, the numbers of Green-flies increase very rapidly. Most of these youngsters are wingless; some are winged, and migrate to other food-plants; all are females. Towards autumn, more and more winged forms appear, some of them being males, some females. Pairing then takes place for the first time, and the eggs, destined to survive the winter, are deposited in suitable sites.

In some Aphids, notably in the genus Chermes, the life-history is far more complicated. In Chermes abietis there are six generations, some being spent on spruce and some on larch.

All the Aphids are constantly beset by enemies: they would increase out of all bounds were this not the case. Ladybirds, Syrphid-flies, Lacewings, various Hymenoptera, and blue-tits, all serve to keep them in check. The relations of Ants to Aphids is treated elsewhere. 
Aleurodid a.-Opaque white wings; antennæ sevenjointed.

These minute four-winged insects cannot easily be confused with other Bugs, though in their early stages they bear some resemblance to Coccidce. They are known as White-flies, on account of the mealy covering of their wings. Some of them are somewhat serious pests in orange-groves, not on account of the damage they do themselves, but because of a fungus which grows profusely on the honey-dew they secrete. The most harmful of these White-flies is Aleurodes citri. In Britain there are three species, of which the commonest is $A$. brassicae, and is frequently met with on cabbages.

The metamorphosis of the White-flies is complex, and has given rise to considerable confusion.

Coccid a.-Feet with but one claw; males winged and lacking mouth-parts; females wingless, and usually scale-like or gall-like.

This large and widely distributed family contains some of the greatest pests of the husbandman. Popularly known as Scale insects or Mealy Bugs, many of them are of great biological interest.

The typical female Scale insect remains stationary during almost the whole of her life, with her beak pierced deeply into the tissues of the plant on which she dwells. Her body becomes covered with a waxy scale, and beneath this scale she either lays her eggs or produces living young. The larvæ at once wander to other parts of the tree, and become anchored to a new position, by means of their beaks. The females go through from three to five moults before becoming adult and truly scale-like. Eventually they become 
eyeless and legless. The males, however, after the second moult, assume relatively large wings and long antennæ. Their eyes are large and their legs are long, and, curiously enough, where one would expect to find the mouth, there are ocelli.

The female becomes an egg-producing machine and little more; the one function of the male is to discover and fertilize some female.

Among the important species of this family may be mentioned the San José Scale, Aspidiotus perniciosus, introduced into America from China, and a serious fruit pest; the Cottony Cushion Scale, Icerya purchasi, introduced into California from Australia, and responsible for an enormous amount of damage in the orange-groves till the Ladybird, Novius cardinalis, its inveterate enemy, was brought from the Antipodes to keep it in check; the Black Scale Saissetia olece, another orange pest controlled, partially at any rate, by the Hymenopteron, Scutellista cyanea; the Mealy Bugs, unprotected by any scale and common in our greenhouses, the bestknown being $P$ seudococcus citri.

Some of the Coccids are useful. From Carteria lacca is derived lac, from which shellac is obtained. Coccus mannifera secretes an edible honey-dew, the manna of biblical times. Ceroplastes ceriferus and Ericerus pela both produce wax of commercial value in India and China respectively. Dyes are also obtained from various Coccids-Cochineal, Coccus cacti, being known to everybody. 
PLATE XV

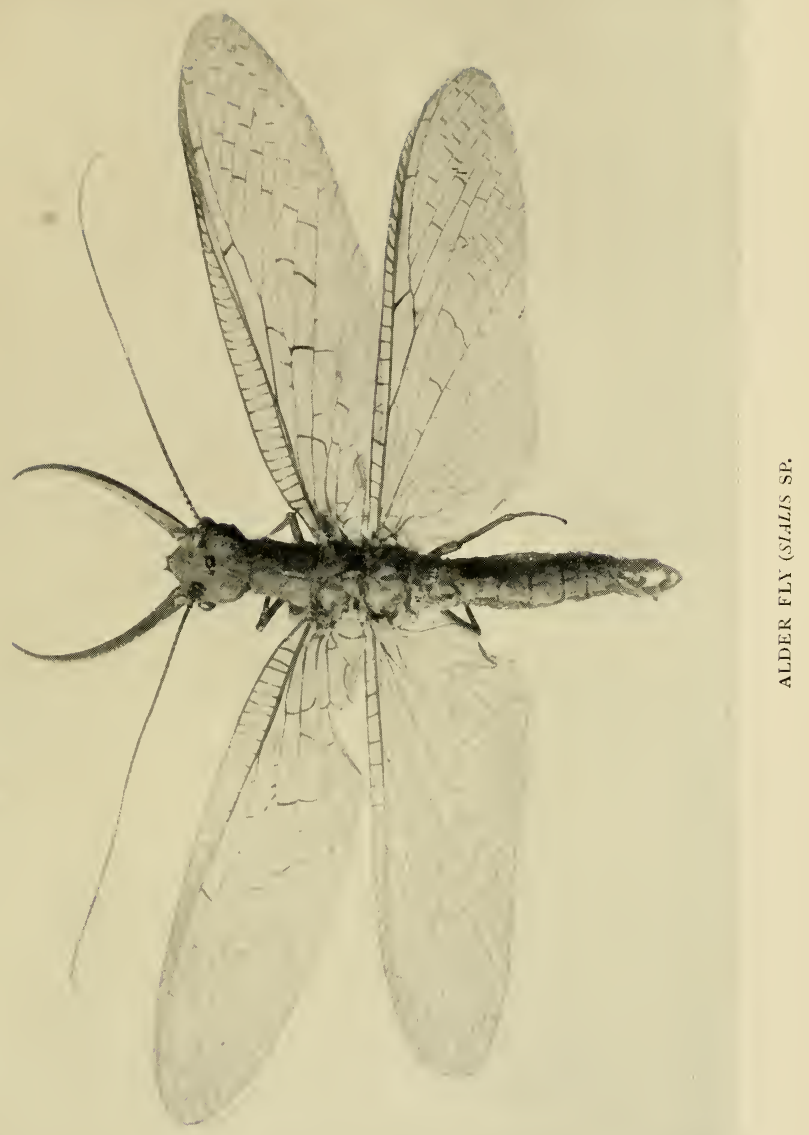



CHAPTER V

\section{PLANIPENNIA, TRICHOPTERA, AND LEPIDOPTERA}

SUBCLASS ENDOPTERYGOTA.

Order Planipennia.

HEADS of moderate size; antennæ filiform or clubbed and many-jointed; four scaleless wings; hind-wings sometimes with long appendages; metamorphosis complete.

This order includes a number of families which, with others, made up the old order Neuroptera. It is but poorly represented in Britain, but the exotic Planipennia include some very interesting and a few decidedly beautiful species.

SIALID $2 .-F o u r$ large membranous wings of approximately equal size; neuration simple; antennæ long.

Species of this family are known as Alder-flies in this country; in America they are variously referred to as Dobsons, Fish-flies, and Hellgrammites. Our common species, Sialis lutaria, may often be seen near water in which its larvæ dwell. It is a smoky-black insect with prominently veined wings, spanning about an inch and a half. The upper wings fold over the lower in characteristic manner, and diverge at their apices. Its head and thorax are broad, and when 
discovered it is more likely to seek safety by running away than by taking to flight.

The life-history of the Alder-fly can be summed up in a few words. The female deposits her eggs upon the leaves of some plant, which may or may not grow close to the water. About a hundred cylindrical, elongated eggs are laid in groups. When the larvæ emerge, they crawl to the nearest water without loss of time; there they settle in the mud for about a year, and gain their sustenance by devouring other aquatic animals. The full-grown larvæ measure about an inch in length; their arge thoraces plainly show division into three segments. Seven pairs of tracheal gills are appendages of the tensegmented abdomen; the last abdominal segment is modified into a pointed double air-tube which acts as a supplementary gill.

Pupation takes place in an earthen cell at some distance from the water; the pupal stage lasts nearly a month, then the membranous pupa-case is split and the Alder-fly emerges.

The American Dobson, Corydalis cornuta, does not differ very markedly in its life-history from our native species. Howard says that it has more popular names than any other American insect. "They are: Dobsons, crawlers, amby, conniption bugs, clipper, water grampus, goggle goy, bogart, crock, hell devils, flipflaps, alligators, Ho Jack, snake doctor, dragon, and hell diver." We mention this, not because of its importance, but because it serves to emphasize a remark on another page, that the entomologist should learn to rely on scientific names, and not to bear upon the broken reed of popular nomenclature. 



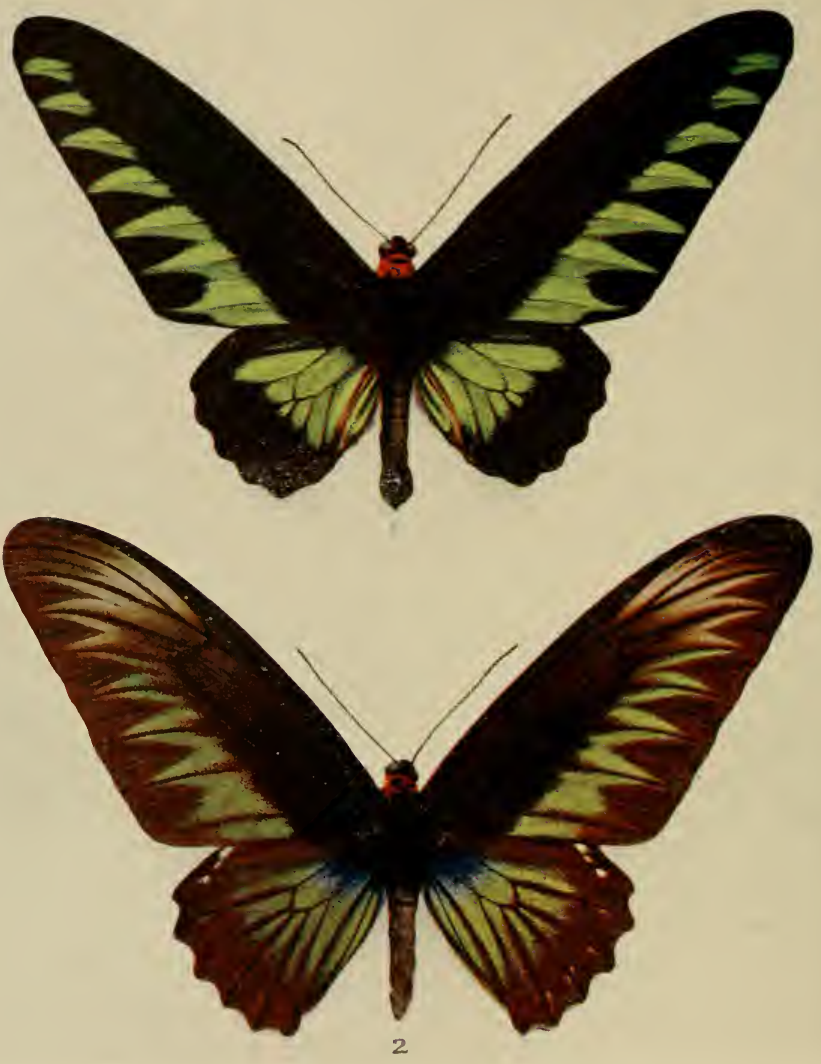

ORNITHOPTERA BROOKIANA See pame $\mathbf{1 4 0 .}$

1. Male

2. Female 
Corydalis is an evil-looking creature with a wing-span of more than four inches. The females have very powerful jaws, capable of inflicting a severe bite; the males, though more formidable-looking, with long, curved jaws more than an inch in length, are really harmless, and their jaws are used to hold the females during pairing.

In one respect, inadvertently, perhaps, these insects show more consideration for their young than do their British relatives. Their eggs are always laid upon some object overhanging the water, so that the larvæ, when they hatch, can fall straight into the element which is to be their home. These convex egg-masses, white and chalky-looking, each contain about three thousand minute eggs set on end. "Sometimes they are so abundant as to make the rocks look as though someone had splashed whitewash upon them profusely with a brush." The larval life of $C$. cornuta lasts nearly three years.

RAPHIIDA.-Closely allied to Sialidae; head long; prothorax long and tapering in front.

On account of the curious structure of their heads and prothoraces, these insects are known as Snake-flies. Very little has been learned of their life-histories; the larvæ live under bark and are exceedingly voracious; the naked pupæ, which closely resemble the adults, except that their necks are not long, occur in the same situations.

MaNTISPID $2 .-H i n d-w i n g s$ without an anal space; front legs formed for grasping.

These insects receive their family name from their remarkable resemblance to the Mantida. Their necks 
are long, their fore-legs are similar to those of Mantis but their wings, apart from many other characters, show that they are not closely related to the insects they simulate.

We have no British species of the family; so far as is known, many of these insects appear to be semi-parasitic. A South American species lives in Wasps' nests; a European species preys upon Spiders and their eggs. Each of their very small and very numerous eggs " is placed at the tip of a long stalk, very much the same way as are the eggs of the lacewing-flies. The eggs are laid in the autumn and the larvæ hatch before winter, but remain hidden, without food, until spring. Then they search for the egg-cocoons of certain spiders, pierce them, and enter among the eggs. When the eggs are nearly ready to hatch they eat them, and the young spiders as well, until they are full grown, moulting only twice and changing to pupæ or nymphs within the larval skin."

CONIOPTERYGIDA.-Minute insects with mealy wings. These little white insects are remarkable for being the smallest of the Planipennia. Their larvæ prey upon Scale insects and Aphides, and are usually met with upon conifers.

Myrmeleonid e.-Superficially resemble Dragon-flies, but their bodies are shorter, their short antennæ are clubbed, and their fore-wings are devoid of nodes.

The life-story of the Ant Lion is known to most people, though the insects themselves may be unfamiliar. The larvæ of this family are among the most curious and interesting of all insects.

Sand is an essential to Ant Lions, for without sand 
their larvæ could not form the pits which are essential to their existence. The gauzy-winged females deposit their eggs in the sand, and directly the larvæ hatch they lose no time in setting to work to construct the traps which will provide them with food.

Needless to remark, the structure of the larvæ differs according to the species, but, speaking generally, they are all somewhat flattened, almost circular six-legged creatures, with flat heads and formidable jaws. It is said that they scrape the sand on to their flat heads with their fore-legs, and then, jerking their heads backwards, throw the load to some distance. The first operation is the making of a circular groove in the sand and the throwing away of the excavated materials. More and more concentric grooves are made within the original one, till the final operations result in the formation of a steep-sided pit, shaped like an inverted cone. The larva then descends to the bottom of the pit and, with the exception of his powerful jaws, buries himself in the sand. Any small insect, finding itself on the shifting sands of the pit-sides, promptly rolls to the bottom, is seized by the ever-watchful larva, its juices are sucked from it, and its carcass is jerked from the pit. A larger insect, on finding itself slipping to the bottom of the pit, may make efforts to escape-efforts which in ordinary circumstances would be successful. The Ant Lion, however, is not so passive às he appears; he showers sand upon the struggling insect and hastens its descent.

Although larval Ant Lion habits have been witnessed and described time and again, there is little reliable information concerning the deposition of the eggs, the 
number of larval moults, pupation, etc. One fact is known of a certainty: the larval period may be extended almost indefinitely, and its duration depends largely upon the amount of food the individual is able to obtain. Plentiful food shortens the time; long fasts -and the Ant Lion, in common with most predaceous larvæ, can fast for inordinately lengthy periods_-ntail a protracted larval existence. Silken cocoons are spun in the sand by the fully fed larvæ; they are always studded with sand.

Hemerobimz.--Very similar to Myrmeleonida, but their antennæ are beaded.

These insects are called Aphis Lions, for the reason that the larvæ of many species prey upon Aphides. It is another family concerning which very little is known.

The largest of the British Planipennia, Osmylus fulvicephalus, belongs to this family. Its broad transparent wings span nearly two inches, the fore-wings are slightly spotted with brown, and it frequents the neighbourhood of streams, for its larvæ are semi-aquatic. Larvæ of the genera Climacia and Sisyra are also aquatic in their early stages.

The most interesting feature concerning the terrestrial larvæ of the Hemerobiida is the curious habit possessed by some of them of ornamenting their bodies with the skins of their victims. All the land-dwelling larvæ are active, voracious creatures; all have long, powerful, grooved jaws. Their prey is seized in the jaws and the life-juices sucked therefrom through the grooves. Many of the larvæ are ornamented, over their backs and sides, with bristle-covered tubercles. Species so clothed take great pains to disguise themselves by firmly attaching 
PLATE XVII
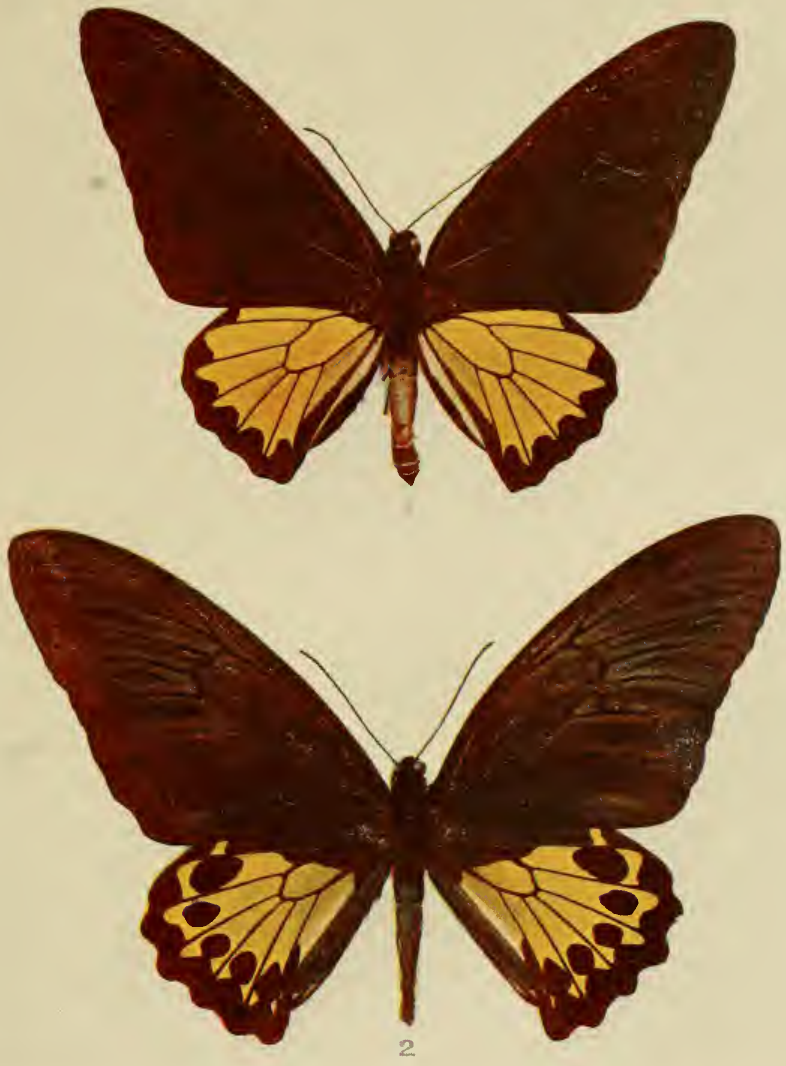

ORNITHOPTERA HEPHASTUS See paye 140.

1. Male 2. Female 

the remains of their insect food to the tubercles; no Red Indian ever gathered scalps more assiduously than some of these insects collect the remains of their feasts; heavily laden larvæ cannot be recognized as insects.

Chrysopide.-Characters very similar to Hemerobiid $x$, but antennæ bristle-shaped.

The delicate Lacewings or Golden Eyes are familiar to most people. Their pale green, filmy wings, their slender bodies, their long setiform antennæ, and their brilliant metallic-looking eyes, render them unmistakable. Despite their delicacy and beauty, they can emit a most unpleasant odour, a habit which has earned them the name of "Stink-flies" in some quarters.

Several species of Chrysopa are common in Britain, and the life-history of $C$. vulgaris may be taken as typical of them all. The female lays her eggs in clusters, usually upon a leaf, almost invariably amongst a colony of Aphides. The eggs are worthy of particular attention. Each egg is raised from the leaf-surface upon a thin stalk; the egg-mass resembles a number of minute pins piercing the leaf-surface. The eggs are not of this peculiar form without good reason; all Chrysopid larvæ are exceedingly voracious, none of them object to feeding upon their own kind, so that, were the eggs of more ordinary mould, the young larvæ, when he entered the world, would make his first meal of his still unborn relatives. The stalked eggs prevent such a catastrophe.

The larva emerges by biting a hole in the top of his egg; he descends to the leaf, and at once begins to prey upon the Aphides which surround him. His jaws are hollow and powerful, like those of the Hemerobiid larvæ; he seizes his prey in the softer portions of their 
bodies and sucks them dry. Some non-British species possess the habit we have just described of ornamenting their bodies with the remains of their victims. The Chrysopid larva, whatever its species, " always seems hungry and always to be feeding when it can find anything upon which to feed, and its rapidity of growth is limited only by the abundance of the food-supply." Vulgaris, when fully fed, is about half an inch long and of a peculiar pinkish colour.

The cocoons are of silk and nearly globular; the larval spinnerets are situated in the tail, and the jaws are used to arrange the silk in position. When the adult Chrysopa emerges, the top of the cocoon lifts up and remains attached to the base like a lid. Few insects are more beneficial than the Lacewings; unfortunately, they are much preyed upon by parasites.

\section{Order Trichoptera, or CADdis-Flies.}

Antennæ long and slender; four hairy wings; mouthparts not fully developed; tarsi usually five-jointed; metamorphosis complete.

With the majority of orders the perfect insects are more familiar than the larvæ; here the reverse is the case. Everyone knows the curious larval cases of these insects; few have seen or recognized the moth-like "flies." The order has been strangely neglected by entomologists, and there is a considerable diversity of opinion as to its proper subdivision. It may be well to study the typical life-history of a Caddis before considering the peculiarities of the various families.

The female lays her eggs during the summer in a mucilaginous mass, and they are usually, though not 
invariably, attached to a water-plant. These eggmasses may assume varied forms according to the species: they may be disc-shaped, rope-like, or horseshoe-shaped; green they always are, owing to the colour of the eggs, which shows plainly through the mucilage.

In less than a month the larvæ emerge, and, being soft-bodied and a likely prey for voracious creatures, they lose no time in constructing their dwellings of leaves, sticks, shells, sand, or similar material, and they are always characteristic of the species. The case, whatever its design, is so made that the larva need never expose more of its person than its horny head and thorax. Respiration is performed by means of nine pairs of tracheal gills, and the larva keeps its place within its home by means of a pair of formidable recurved hooks on the end of its body and by three fleshy protuberances, capable of retraction and extension, on the first abdominal segment.

The larvæ, with the exception of those of one group, are all vegetable-feeders; their existence continues through the winter, pupation taking place in the spring. When about to pupate, the larva spins a silken web at either end of its case, and, thus secure from its enemies, it passes into the next stage. The Caddis pupa is an extraordinary creature and quite unlike the "fly." It is white; its legs, wings, and antennæ are free; upon its abdomen are respiratory organs; and its mouth is armed with powerful mandibles. The latter organs are used to bite a way through the ends of the case when the time of emergence arrives. Then the semi-active pupa floats to the surface of the water, climbs to some 
near-by plant, its pupal skin, along with the formidable mandibles, is shed, and the Caddis-fly emerges with startling rapidity. Of a pale greenish hue at first, the insect soon assumes the grey, brown, or black colouring common to British Trichoptera.

Phryganeide.-Distinguished by having four spines on middle tibiæ; three ocelli.

This family contains the largest of the Trichoptera. The larvæ all construct cylindrical cases of spirally arranged material; the cases are open at both ends. Our common Phryganea grandis is a brown insect, measuring two inches in wing-span. Its larval cases are made of minute fragments of leaf cut by the larva, and arranged in a spiral manner to form an open-ended cylinder. Some of the Asiatic species are quite ornate; a Japanese Phryganea has yellow-bordered brown hindwings; an Indian species has purple hind-wings, tipped with yellow.

LIMNOPHIDIs.-Two or three spines on middle tibiæ; three ocelli.

A family with very varied larval cases. Many species construct their cases, wholly or in part, of small WaterSnail shells. Sometimes these shells contain living Snails, which "are afforded comparatively rapid transportation, whether they desire it or not." The British Limnophilus flavicornis has this habit; L. rhombicus arranges small sticks transversely to form its cylindrical case; other species of the genus construct their cases of sand.

To this family belongs the only non-aquatic Caddisfly larva; it frequents damp moss, often at the bases of trees far removed from water. 

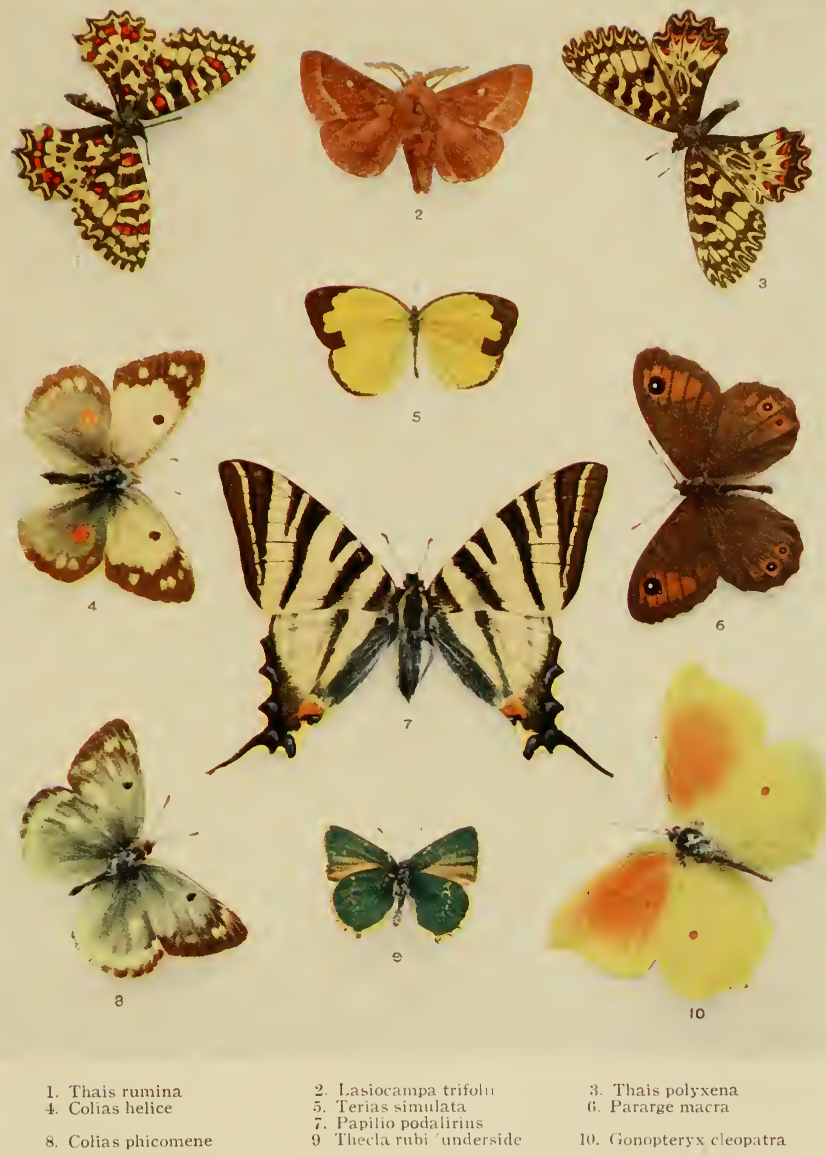

RhyасорніLIDж.-Male palpi five-jointed; last two joints of palpi not flexible.

The larvæ of this family all frequent running water, and in consequence they all make cases, which they attach to rocks by means of silk. None of the cases are of a very elaborate nature, and are all very similar to those of the common Stenophylax. The pupæ of Rhyacophilidae are protected by thin but tough brown cocoons.

HydRoptiudds.-Male palpi four-jointed; no spurs on anterior legs; no ocelli.

The smallest of the Trichoptera. The larval cases are made of silk, studded with grains of sand, and have an opening at each end. The larvæ probably breathe through their skins, for they have no visible breathing organs.

Sericostomatide.-As Hydroptilidoe, but spines on anterior legs.

The flies are very hairy; their larvæ live in running water, but they construct free cases of sand or pebbles, some of them very closely resembling helical Snailshells.

LEPTOCERID \&.-Last joint of palpi long and flexible; base of antennæ long and large; no ocelli.

The species are conspicuous on account of their very long antennæ; the larvæ usually live in running water, and build cylindrical, slightly carved cases of sand.

Hydropsychid a.-Similar to Leptoceridce, but antennæ shorter and wings broader.

These are the only carnivorous Trichoptera; they live in running water, and the fixed larval cases are formed largely of silk. The larvæ of Plectrocnemia 
build funnel-shaped hiding-places with silken webs about the entrance, very similar in design to the Broadland Duck decoys. Insects caught in the webbing are eagerly devoured by the Caddis larvæ.

\section{Order Lepidoptera, or Butterflies and Moths.}

The Lepidoptera are four-winged insects, and in the majority of cases their wings are covered with scales; bodies with scales having the appearance of hair;

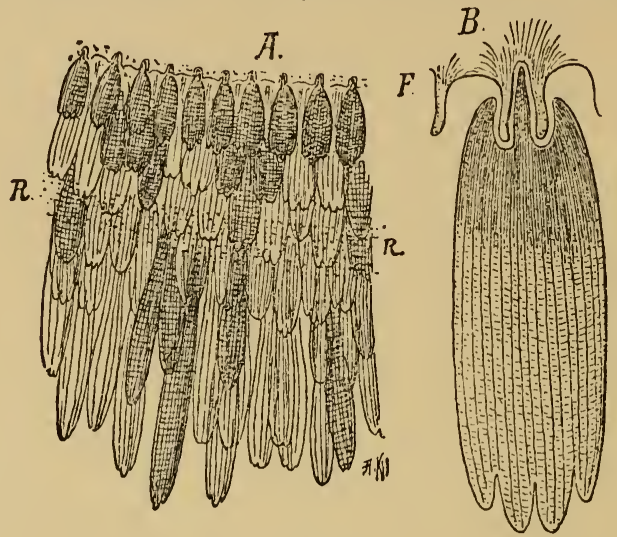

Fig. 5.

$A$, Piece of wing of the White Cabbage Butterfly (much magnified to show the scales). $R$, Margin of wing; the scales covering it are very long. The dark scales are of black colour, the light ones white. $B, A$ scale (more strongly magnified). It is fixed by a small peduncle in a depression of the wing membrane, $F$.

mouth-parts of adults adapted for imbibing liquids, never for piercing or biting; larvæ with biting mouths; metamorphosis complete

The order is subdivided into two series: 
PLATE XIX
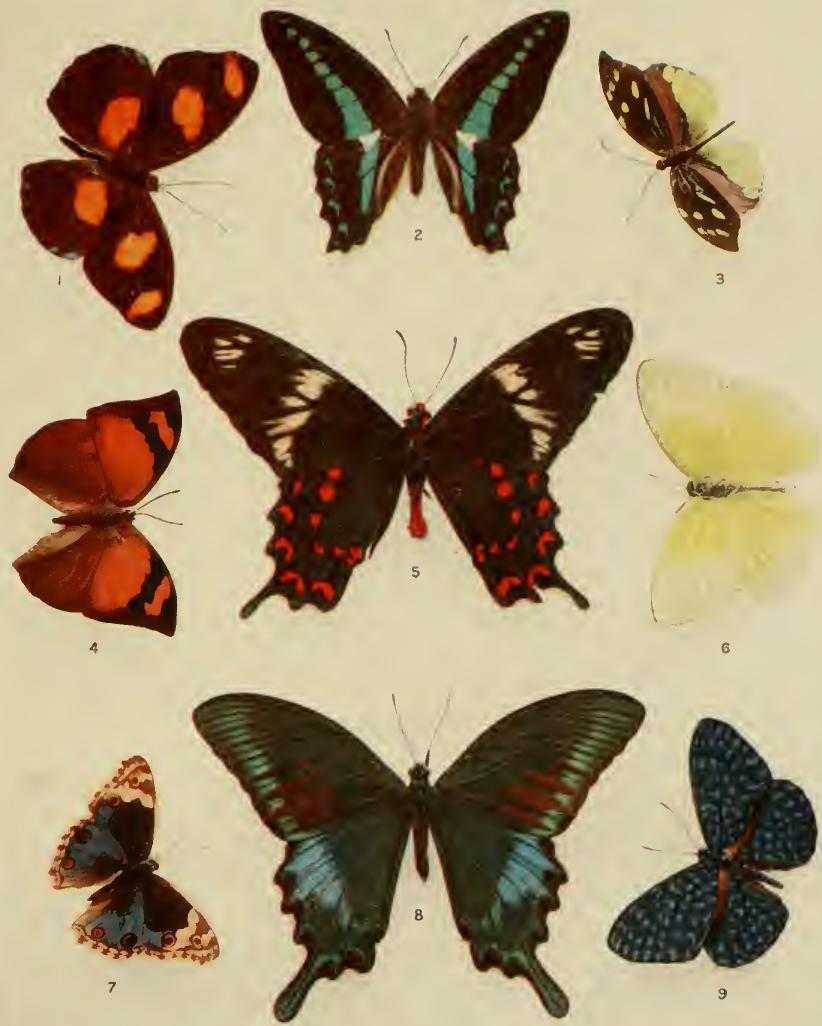

1 Epicalia numilia

4. Chlorippe cherubima

7. Junonia orythia
2 Papilio sarpedon

5. Menelaides hector

8. Papilio ganesa
3. Dismorphia nemesis

6. Callidryas neleis

9. Ageronia velutina 

Series 1. Rhopalocera, or Butterflies, with knobbed antennæ or swellings towards the tips of these organs. Usually diurnal.

SERIES 2. Heterocera, or Moths, with antennæ which are very rarely knobbed. Usually nocturnal.

With the exception of a few aberrant forms, there are few Buttertlies or Moths which even children cannot

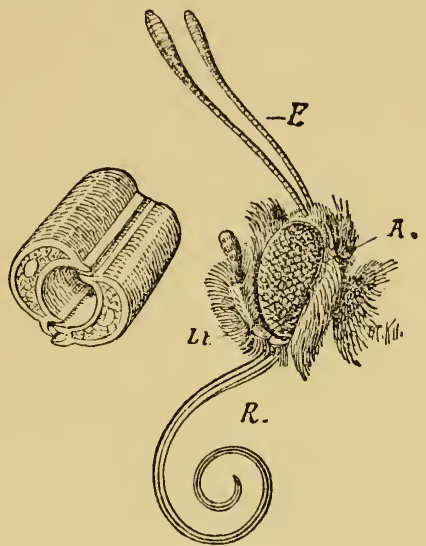

Fiq. 6.-Head of the White Cabbage Butterfly (Magnified), and on the Left a Portion of tie Proboscis (more Highly MagNified).

$F$, Antennæ; $A$, eye; $R$, proboscis; $L t$, labial palpi.

recognize as such. Owing to their brilliant colouring, their active habits, and, in many species, their large size, they are familiar objects everywhere. "In respect of intelligence the order is inferior to the Hymenoptera; in the mechanical adaptation of the parts of the body it is inferior to Coleoptera ; and in perfection of metamorphosis it is second to Diptera." 
Despite the fact that one of the most useful of all insects, the Silkworm, belongs to this order, the Lepidoptera are decidedly injurious. With a few unimportant exceptions, the larvæ are all vegetable-feeders; many of the species are prolific, and in consequence crops are frequently ruined by the depredations of the immature insects.

The adults are harmless, as a rule; their mouth-parts are only adapted for imbibing nectar and similar liquid food. There are, it is true, one or two species with peculiar and noxious habits; a species of Noctuid, for instance, is in the habit of drinking its fill from the eyes of cattle, and, as it passes from one beast to another, it is presumed to transmit ophthalmia.

Though no order has been more assiduously hunted, captured, and preserved than the Lepidoptera, it is remarkable that, up till quite recently, less real scientific knowledge of these insects had been acquired than of many other less attractive orders. It is small wonder that Butterflies and Moths have been much sought after by collectors. Some are drab, some bizarre, but the majority are of surprising beauty. They owe their attractiveness to the scales, arranged slate-wise, on their wings, and, in the typical Lepidoptera, the wing-expanse is large compared to the insect's body. It has beer estimated that there are as many as one and a half million scales on the wings of some species. Each scale is a little flattened, bag-like structure, stalked at its base, and fitting into a cup-shaped cavity on the wingmembrane.

One of the most interesting phenomena connected with Lepidoptera is the "seasonal dimorphism" of 
PLATE XX

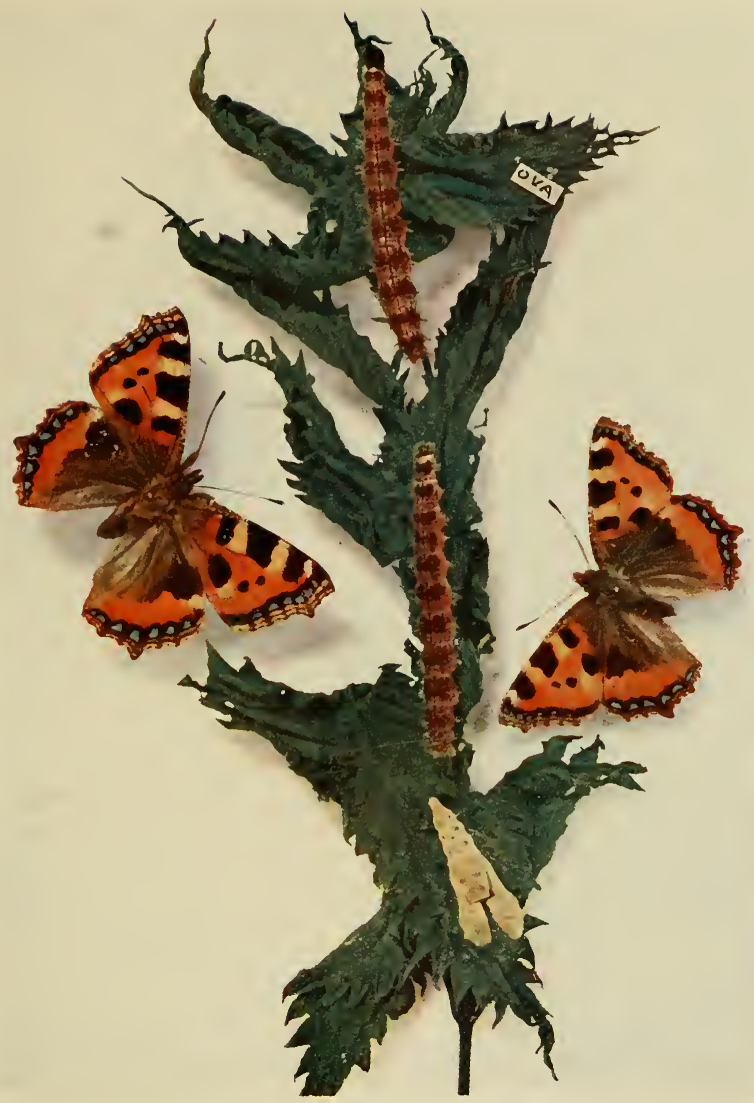

VANESSA URTICA SMALL TORTOISESHELL)

Ova, larvæ, pupæ and imago 

certain species. This has been fully described elsewhere (p. 26), but it is of the greatest interest to the scientist and often the cause of much trouble to the collector. Mimicry, also, is very common in this order, but this phenomenon is also referred to on another page (p. 47).

\section{Series 1. Rhopalocera, or Butterflies.}

Although the series is a large one, it is curiously uneven in its distribution. South America is particularly rich in Rhopalocera; New Zealand, with less than two dozen species, particularly poor. We have rather more than sixty native species, practically all of which we are fortunate enough to be able to illustrate in colour.

NymphaLID e.-Front pair of legs small; tarsi of male with one joint, of female with five; claws absent. Pupæ pendulous; larvæ either spined or smooth, but even in the latter case the head bears spinous appendages.

There are eighteen species of this family native to Britain; it includes the Fritillaries, the Red and White Admirals, the Peacock, the Tortoiseshells, and the somewhat aberrant Purple Emperor. Among the exotic species of the family are the Ieaf Butterflies, Kallima spp., and the South American species of Ageronia, with the un-Butterfly-like habit of making a noise.

In point of numbers the genus Vanessa far exceeds all others in this country. The Small Tortoiseshell, Vanessa urtica, is the commonest of all our Butterflies, and it is of the greatest interest to the biologist. It is usual amongst the Lepidoptera for the females to lay their eggs and leave them to their fate. In some species the winter is passed in the egg stage; others, again, may elect to winter as pupæ, and there are species with 
hibernating larvæ. The Small Tortoiseshell, however, is original, for the adults themselves hibernate, becoming active again in early spring, maybe before the nettles, food-plants of their larvæ, are far above ground, but knowing instinctively that they will be well advanced before the hatching of the spring-laid eggs. The Large Tortoiseshell, V. polychloros, whose larvæ feed upon elm, cherry and willow, is less common, and, though very similar to its smaller relative, a comparison of our two figures will show that the careful entomologist need never confuse the species.

The Peacock Butterfly, $V$. io, an aptly named insect, is too common to need description; its larvæ feed upon nettles. Another nettle-feeder is the Red Admiral, $V$. atalanta, one of the most beautiful of our native butterflies. Its habits are the subject of some controversy and by many it is presumed that we are indebted to the Continent for our annual supply of this insect. It is certain that the migratory habit is by no means uncommon amongst the Nymphalidoe, and in no species is the nomadic instinct more pronounced than in the Painted Lady V. cardui which has spread and is still spreading to distant regions of the world. Its larvæ may be taken on thistles, nettles, and various other food-plants. The Comma Butterfly, V.c.album, may easily be distinguished from all the other native species of the genus by the indented outline of its wings. When in repose, it approaches most nearly to the deadleaf mimics by the colouring of its lower wing-surfaces. Its larvæ are not confined to one food-plant, as is so often the case; they feed on nettles, hops, willows, sloes, elm, and even gooseberry. 

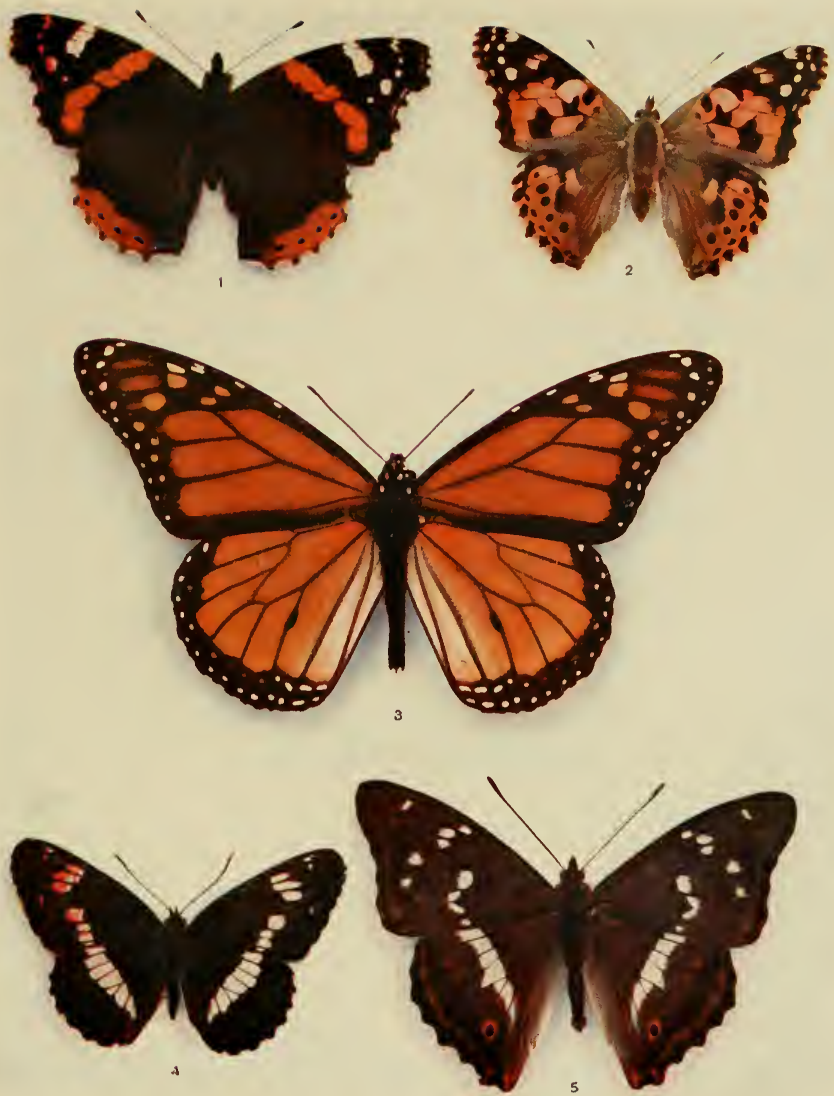

1 Vanessa atalanta Red Admiral

2. Vanessa cardui (Painted Lady)

4 Limenitis sibylla White Admiral

5. Apatura iris Purple Emperor 

The rarest of all our Vanessas is the Camberwell Beauty, $V$. antiopa, a summer visitant to these islands. It is an insect of striking beauty and commanding size; well-grown specimens may measure well over three inches in wing-span.

Lack of space forbids more than a passing mention of our native Fritillaries. The larvæ of the PearlBordered and Small Pearl-Bordered Fritillaries, Argynnis euphrosyne and A.selene, and of the Queen of Spain, the Dark Green and High Brown Fritillaries, A. lathonia, $A$. aglaia, and $A$. adippe, all feed upon species of Viola. Those of the Silver-Washed Fritillary, $A$. paphia, feed on wild raspberry as well as upon Viola; and those of the Greasy, Glanville, and Heath Fritillaries, Melitaea aurinia, $M$. cinxia, and $M$. athalia, feed upon the narrow-leaved plantain, the first-named also favouring scabious, foxglove, and speedwell.

The White Admiral, Limenitis sibylla, becomes more and more rare each year. Its larvæ, which may be looked for on honeysuckle, are gaily clad green creatures with red heads and reddish spines. The Purple Emperor, Apatura iris, is a handsome insect which may be looked for on oaks. Its larvæ feed upon willows and poplars, and they are quite characteristic. They are slug-like in form, green in colour, and armed with a pair of horns on their heads. They hibernate through the winter, and in consequence the period of pupation is much reduced in this species.

The Dead-Leaf Butterflies are wonderfully interesting from the fact that when at rest they very closely resemble dried leaves. When they settle they place their wings close together in a vertical position; their 
under-sides, in contrast to their upper surfaces, are a dull brown colour. Each hind-wing bears a short tail, and these tails, placed together and resting on the twig upon which the insect has elected to settle, simulate a leaf-stalk. The deception is heightened by a dark line which runs from the tail to the tip of the fore-wing; nothing could resemble more closely the midrib of a leaf. One would imagine that the mimicry could be carried no further, but on each wing there is an "eye," consisting of a transparent spot, destitute of scales. When Kallima folds its wings, the eyes coincide, so that a semi-opaque patch is left right through the wings of the resting insect, just such a patch as might be found on a leaf from which some creature had gnawed a portion.

ERycinid a.-Females with six perfectly formed legs, though the front pair are smaller than the others. Coxæ of fore-legs on the male form a spine, and the unjointed tarsi are devoid of claws.

This is largely a tropical American family; there is only one European species which is found in Britainthe Duke of Burgundy Fritillary, Nemeobius lucina, which is not a true Fritillary. It may easily be identified from our figure, and its larvæ may be sought on primrose.

DANAID $2 .-F r o n t$ foot of female ending in a corrugate knob; larvæ smooth with fleshy protuberances.

These Butterflies are nearly all large insects and boldly marked. None of them are native to Britain, though Anosia erippus, an American species, known as the Milkweed Butterfly or the Monarch, has occasionally been taken in this country. Its larvæ feed upon Asclepias. 


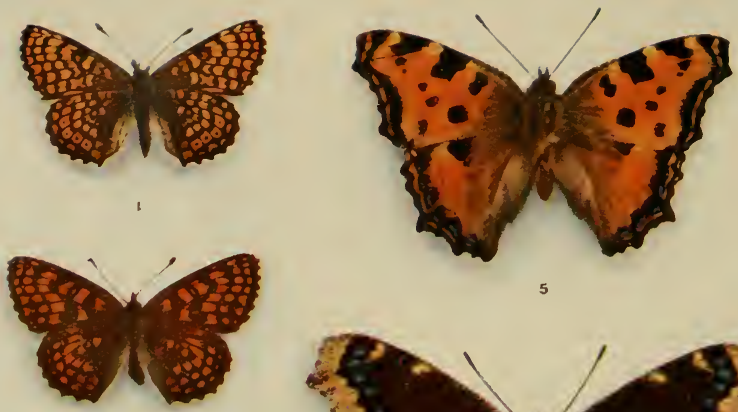

2

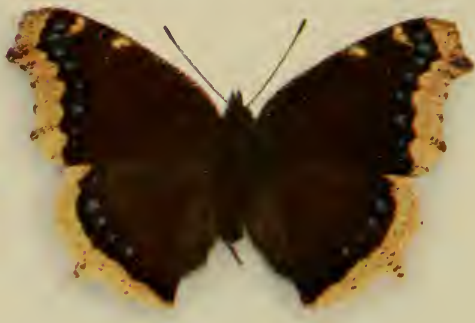

6

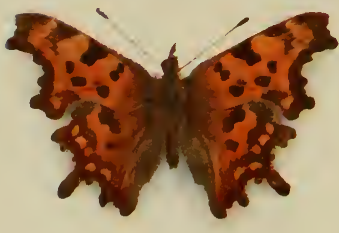

5

is
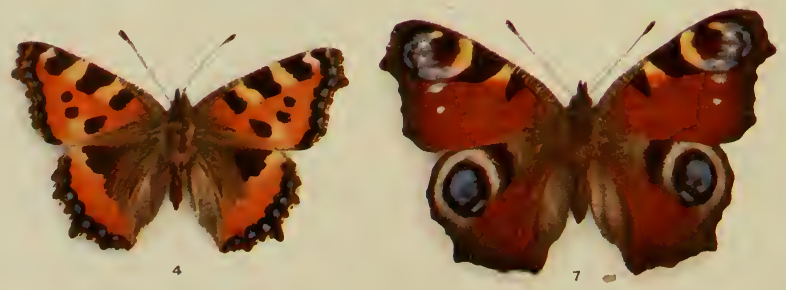

1 Melitæa cinxia Glanville Fritillary 2 Melitiea athalia Heath Fritillary 3. Vanessa c. album Comma

4. Vanessa urticæe Small Tortoiseshell

5. Vanessa polychloros Large Tortoiseshell

6 Vanessa antiopa (amberwell Beauty)

7. Vanessa io Peacock 
SATYRIDA.-Palpi prominent; the veins at the base of the fore-wings often swollen.

There are eleven British species of Satyrida, all of which are figured and are easily identifiable. Their larvæ all feed upon grass, and the adults, though provided with large wings, are generally poor performers in the air. Many species of Satyrida frequent highlands; the Marsh Ringlet, Ccononympha typhon, is only at home in sphagnum bogs and similar situations, whilst the Grayling, Satyrus semele, is a lover of the sea-shore.

MorPHIDz.--A purely tropical family, noted for the brilliant hues of species belonging to the tropical American genus Morpho. The larvæ of many species are gregarious.

Brassolid \&.-A small South American family with somewhat moth-like habits. The enormous larvæ of Caligo eurylochus are green in their early stages; accordingly they take up their residence on the similarly coloured leaves of the banana. As they approach maturity they become brown, and then retire to the dead leaves of the same plant.

Heliconima.-Another tropical American family, mentioned here because the individuals of one species, Heleconius erato, exhibit the exceedingly uncommon phenomenon of "trichroism"-that is to say, individuals of the same brood may be any one of three colours. In this particular case the hind-wings of these Butterflies may be either green, blue, or red.

LYCANID $A$.-Front legs almost as large as the others; male tarsus one-jointed and terminated by a single claw without teeth. 
The family includes the well-known "Blues" and "Hairstreaks." The larvæ of some of the former are said to be carnivorous, feeding upon Green-flies and Scale insects. The pupæ, like those of the Nymphalida, hang downwards from their support, but they are usually still further supported by a silken thread which surrounds the centre of the pupa and is fixed to some object near-by.

There are eighteen British species of this family, of which the Large Copper, Polyommatus dispar, is now but a memory, the last native specimen having been taken in Norfolk about sixty years ago. The Small Copper, $P$. phlacas, is still common; its larvæ feed on sorrel.

Of the "Blues," ten species are figured. The LongTailed Blue, Lyccena botica, cannot really be classed as a native species, but should rather be considered as an occasional visitor. It occurs in many parts of Europe, Africa, Asia, Australia, and the West Indies. The Common Blue, L. icarus, is known to everyone, its larvæ feed on clover. A very similar insect is the Clifden Blue, L. bellargus. The Chalk-Hill Blue, $L$. corydon, as its name implies, is confined to chalk soil. The Silver-Studded Blue and the Azure Blue, L. cogon and $L$. argiolus, are of distinctive hue; the larvæ of the former feed on leguminous plants, those of the latter on the flowers of ivy, holly, or buckthorn. The Mazarine Blue, $L$. semiargus, is exceedingly rare; its larvæ feed upon thrift, and, as may be surmised, the insect is to be sought by the seaside. The Little Blue and the Large Blue, L. minima and $L$. arion, may be recognized by the fact that they are respectively the 

PLATE XXIII

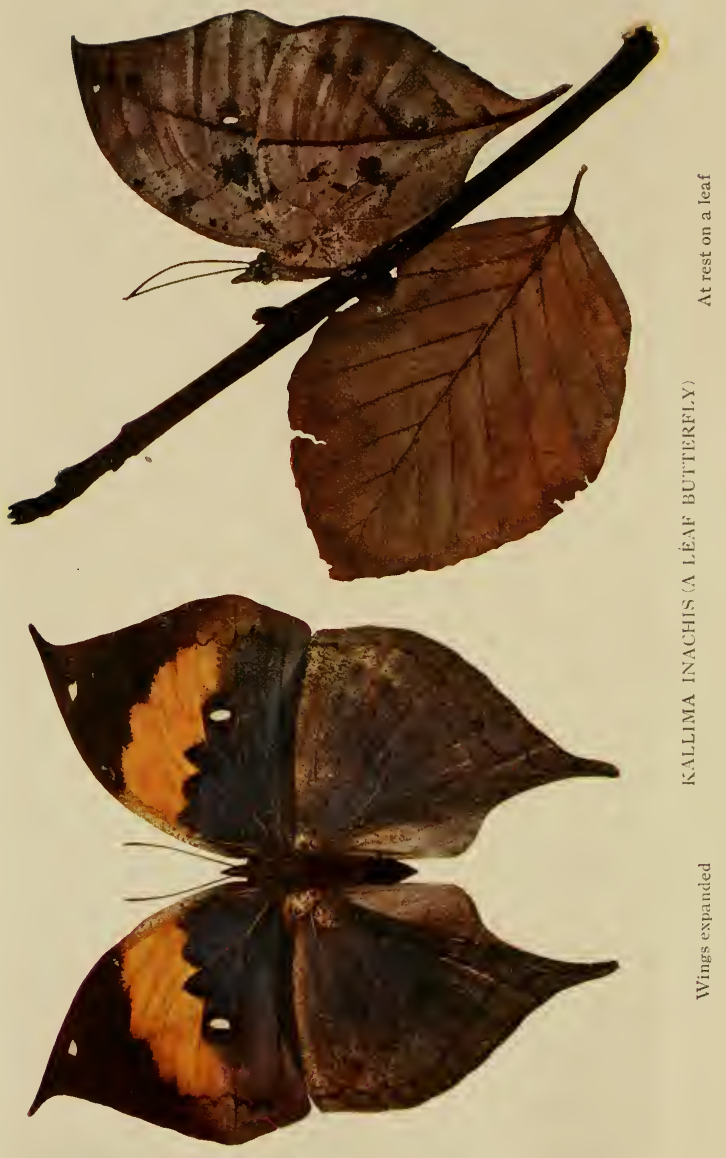


smallest and the largest of our Blues. The larvæ of the former feed on leguminous plants, those of the latter on wild thyme. The Brown Argus, L. astrarche, is brown in both sexes; its larvæ feed on Helianthemum.

The five British Hairstreaks are all dull-coloured on the upper surfaces of their wings; for their identification it is necessary to examine them below. The Purple Hairstreak, Thecla quercus, is the commonest species, and the Black Hairstreak, T. pruni, the rarest. The larvæ of the former feed on oak, those of the latter on the same tree or on sloe. The Green Hairstreak, T. rubi, is the smallest species of the genus in Britain. For so drab an insect as this appears to be when its upper surface alone is viewed, its brilliant green undersurface is somewhat surprising. Its larvæ may be taken on bramble and broom. The Brown Hairstreak, $T$. betula, is the largest British species, and the White Letter Hairstreak, T. w.-album, is easily recognized by the white letter $w$ at the basal angle of the under-side of each hind-wing. Its larvæ feed on elm; those of betulce prefer birch or blackthorn. These curiously named Butterflies are so called on account of the narrow, pale-coloured lines which traverse the lower surfaces of their wings.

PIERID\&.-All the legs well developed in both sexes; claws are toothed.

This family is remarkable for the small colour variation which occurs in the different species. Nearly all of them are decked in some shades of yellow or red or white combined with black. The larvæ of most species are green and smooth, or clothed with a fine pubescence, though those of the Orange Tip, Euchloë cardamines, 
are armed with forked bristles when young, which give place to fine hairs later.

Of our ten British species, the Large and Small Whites, Pieris brassicae and P. rapce, are familiar even to dwellers in large towns. Their larvæ feed upon cruciferous plants. The Green-Veined White, $P$. napi, is equally common, but not in towns; Cardamine spp. provide food for the larvæ. Two rarities of this family are the Bath White, $P$.daplidice, and the Black-Veined White, Aporia cratorgi. The small, fragile, Wood White, Leucophasia sinapis, whose larvæ feed on leguminous plants, cannot be mistaken for any other Butterfly. The Clouded Yellow and the Pale Clouded Yellow, Colias edusa and C. hyale, are quite distinct, despite their similarity of name. They are strong fliers and of migratory tendencies; their larvæ feed on Leguminosa. The Brimstone, Gonepteryx rhamni, is an elegant insect which is easily recognized, among. British Lepidoptera, by its form quite apart from its colouring. The tips of its fore-wings are curved outwards and terminate in an acute angle; its hind-wings are slightly tailed. The females hibernate through the winter and deposit their eggs on buckthorn in the spring.

PapILIONIDA.-All legs well developed; claws large and not toothed; front tibiæ padded.

These are the most ornate of all the Butterflies, the males of some species being truly dazzling in their brilliance, whilst the females are comparatively dullcoloured. Beautiful velvety blacks relieved with brilliant greens and blues and gold are the predominating colours amongst the males of the ornate genus Ornithoptera. 

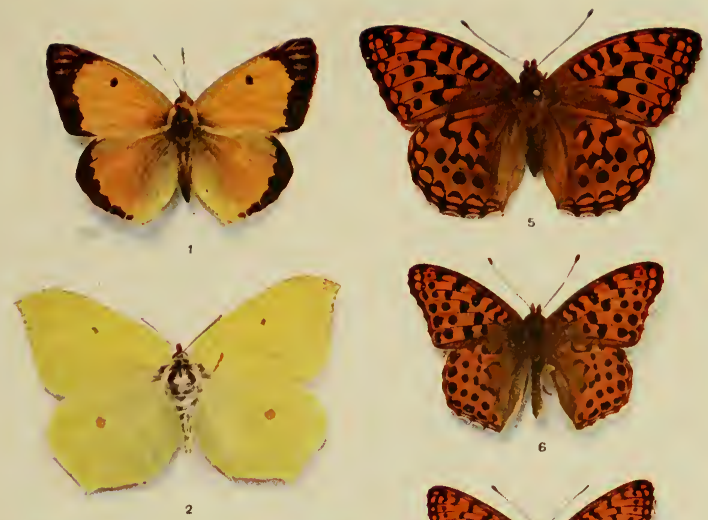

6
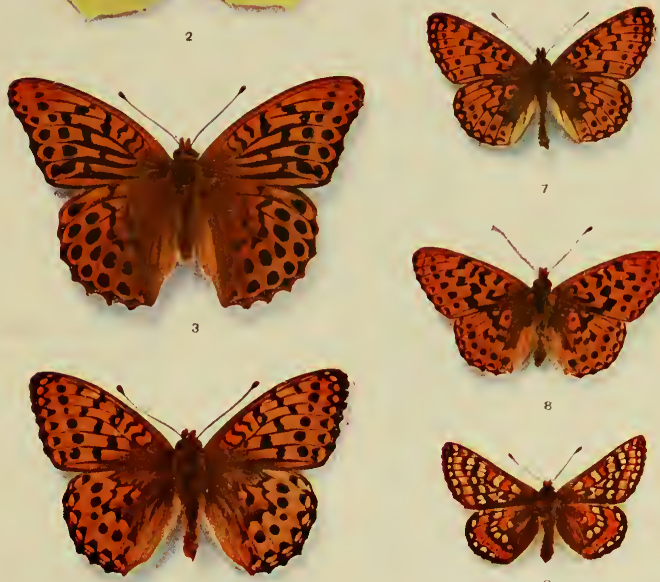

4
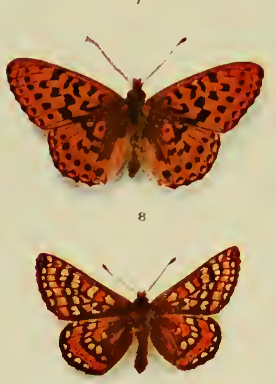

2. Colias edusa (Clouded Yellow)

2. Goneptoryx rhamni (Brimstone)

3 Argynnis paphia (Silver-washed Fritillary

4 Argynnis aglaia (Dark Green Fritillary)

5. Argynnis adippe High Brown Fritillary)

6. Arygnnis lathonia Queen of Spain Fritillary〉

7 Argynnis selene (Small Pearl-bordered Fritillary)

8. Argynnis euphrosyne ('earl-bordered Fritillary) 

Most of the Swallow-Tails, as the Papilionida are called, are South American, nearly all are tropical. In Britain we have but a single species, Papilio machaon, and it is by no means common. It is one of our largest Butterflies, and cannot be mistaken for any other insect. The larvæ, which feed upon the leaves of carrot, fennel, and the like, are as beautiful as the adults. They are green, with belts of black, and the belts are studded with crimson. The pupæ of all the Papilios are affixed head upwards, the reverse of the rule amongst the Nymphatidoe.

HESPERIIDA.-Six walking legs, the front legs not short; stout short claws; tibiæ padded.

The Butterflies of this family are known as "Skippers," on account of their short, rapid, and jerky flights. As a family they are somewhat puzzling; they resemble Moths rather than Butterflies in many respects, and the general consensus of opinion is that they form a connecting link between the Rhopalocera and the Heterocera. Some entomologists would place them in the latter series.

There are eight British species, all of which are figured in colour. Confusion is likely to arise between the Small Skipper, Hesperia thaumas, and the New Small Skipper, H. lineola; the larvæ of both species feed upon grasses. The Lulworth Skipper, H. actocon, is very local, and is confined to a few localities in the South-West. The Checkered Skipper, Cceterocephalus palcemon, is even more uncommon. The Large Skipper, $H$. sylvanus, is by no means uncommon and easily recognized, though it is not very dissimilar to the smaller, rarer Pearl Skipper, H. comma. The Dingy 
and Grizzled Skippers, Nisoniades tagos and Syrichthus malva, are very distinctive.

All the Skippers have the peculiar larval habit of rolling leaves in which they live; pupation also takes place in the same shelters.

\section{Series 2. Heterocera, or Moths.}

The classification of Moths is by no means satisfactory. This is hardly the place to enter into a discussion on the subject; as far as possible, the arrangement here follows the lines of the collection of Heterocera in the London Natural History Museum.

CASTNIID ж.--Antennæ knobbed or hooked.

These Moths are nearly all confined to tropical America and Australia. They are diurnal, and bear a very close resemblance to the Skippers; some of them are agricultural pests.

Saturnidze.-These are the Atlas Moths, and contain some of the largest examples of Lepidoptera. The North Australian, Coscinocera hercules, " is a huge Moth, which, with its expanded wings and the long tails thereof, covers a space of about seventy square inches."

Nearly all the species are remarkable by the possession of large transparent areas on their wings or circular eye-like markings. They are the Moths whose larvæ spin the coarse Tussore silk.

Our only British representative of the family, the Emperor, Saturnia pavonia, is one of our largest native Moths, but one of the smallest of the Saturniidce. It is to be found usually upon heather, the plant upon which its larvæ feed. The latter are as beautiful as the Moths, being bright green studded with red protuberances. 
PLATE XYY

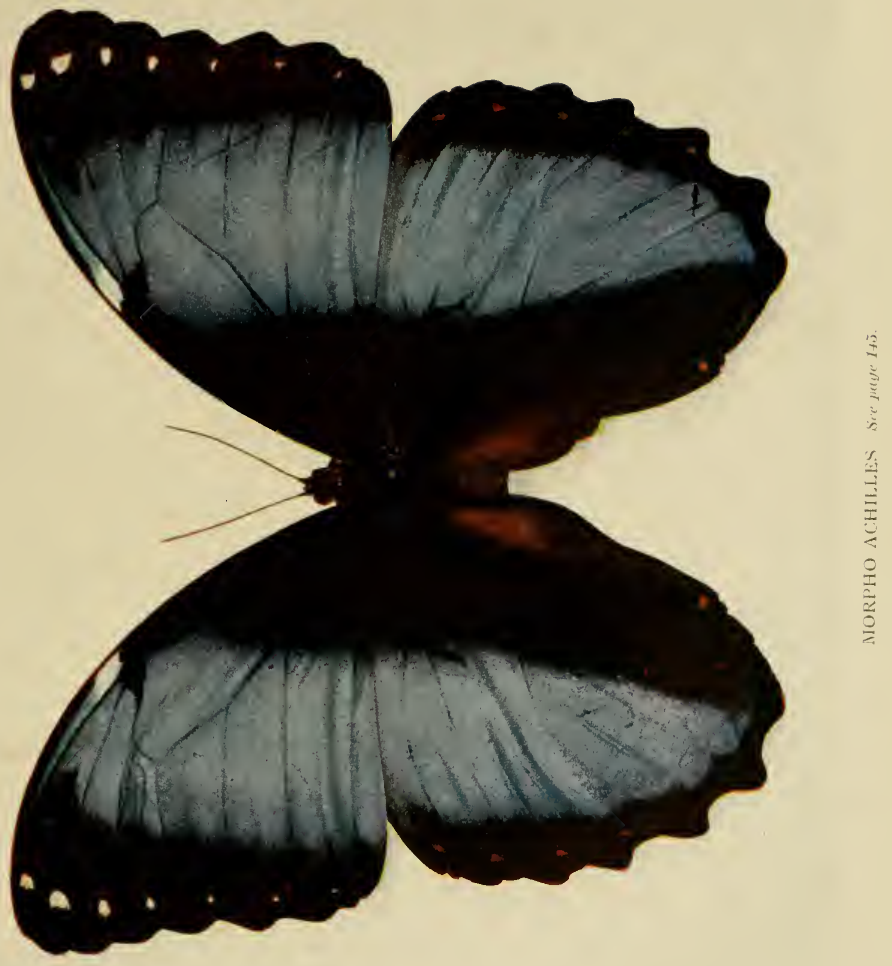



Bомвуспед.-Moths without a proboscis.

A family of uninteresting but useful Moths; they are the true Silkworms.

The Silkworm, Sericaria mori, is a native of Northern China. It has so long been domesticated that it has practically lost the power of flight.

EUPTERotIDE.-A family which contains the remarkable Processionary Moth, Cnethocampa processionea, whose larvæ march in columns, each one headed by a leader.

The larvæ of Palustra, a South American genus, are aquatic, being helpless on dry land.

SpHINGID s.-Hawk Moths. These insects are of large or moderate size; most of them are possessed of a long proboscis; their wings are never large and usually narrow; antennæ stout.

The members of this family all possess a very characteristic appearance which renders them distinct from all other Moths. Our largest native Moth, the Death's Head, Acherontia atropos, belongs to the family. It derives its name from the markings on its thorax. The larvæ feed on potato-plants, and, were they more common, they would be classed as injurious insects. The adults can make a noise, when at rest, by rubbing their palpi against their proboscis. The Convolvulus Hawk Moth, Sphinx convolvuli, is more often taken than the Death's Head; it is the most sombre of our Sphingids. Somewhat similar is the common Privet Hawk Moth, Sphinx ligustri, whose larvæ feed on the plant from which the Moth derives its name. The Spurge and Bedstraw Hawk Moths, Deilephila euphorbice and $D$. galii, bear considerable resemblance to one 
another, but not so much so that they cannot easily be distinguished. Both our native species of Elephant Hawk Moths, the Large Chorocampa elpenor and the small $C$. porcellus, feed on bedstraw in the larval stage; the former also eats willow-herb. The Eyed Hawk Moth, Smerinthus ocellatus, is easily recognized by the "eyes" on its hind-wings; no other British species has these markings. Its larvæ should be looked for on willows and poplar. On the same trees may be found the larvæ of the Poplar Hawk Moth, Smerinthus populi, which possesses particularly broad wings for a Sphingid. The Humming Bird Hawk Moths are always provided with an expansible tuft or tufts of long, hair-like scales on the tip of their abdomen. Our native species, Macroglossa stellarum, is quite common in certain seasons. Its larvæ feed on bedstraw. Quite distinctive, with its clear wings, is the little narrow-bordered Bee Hawk Moth, Macroglossa fuciformis, whose larvæ should be sought on scabious.

NotodonTID A.--Very closely allied to the Noctuida, and remarkable for the curious forms assumed by many of the larvæ.

We have nearly two dozen native species, of which the Puss Moth, Dicranura vinula, is the best known. The larvæ feed upon willows, and curious-looking creatures they are. In their young stages their heads are of moderate size, two protuberances project above the head, a single hump on the forward half of the back, and the tail is long and forked. As they grow older, their heads assume large proportions, and from the forks of the tail two long, whip-like structures can be ejected; their object is presumed to be for the protection 

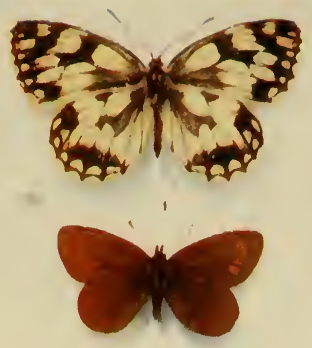

2
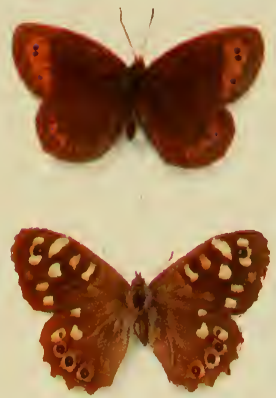

4

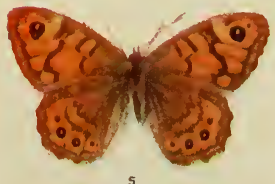

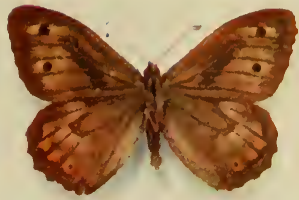

b
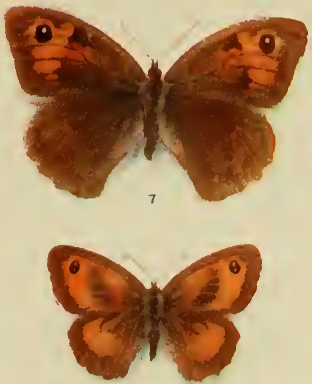

日
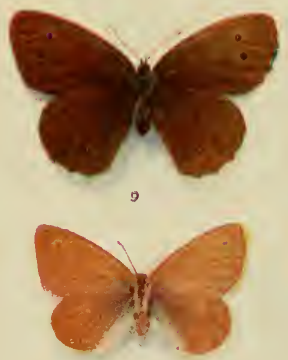

io
1. Melanargia galathea Marbled White 2 Erebia epiphron Mountain Ringlet

3. Erebia æthiops Scotch Argus

4. Pararge ægeria Speckled Wood)

5 Pararge megæra (Vall Brown) (i. Satyrus semele Grayling.

7. Epinephele janira Meadow Brown

8. Epinephele tithonus Small Meadow Brown

9. Epinephele hyperanthus (Ringlet

10. Caenonympha typhon (Narsh Ringlet 

of the larva from enemies. The cocoons of the Puss Moth are hard and formed of wood chips and saliva. When the time arrives for the Moth to emerge, it softens its prison wall with an alkaline fluid and pushes its head, which is protected by a portion of the pupa-case, through the softened part.

More peculiar still is the larva of the rare Lobster Moth, Stauropus fagi, which the lucky entomologist may find on young beech-leaves. The Dragon of old Sepp, Hybocampa mithauseri, has larvæ equally bizarre. Commoner British species are the Coxcomb Prominent, Lophopteryx camelina, with curious larvæ which feed on birch. On the same tree may be found the red and yellow larvæ of the Iron Prominent, Notodonta dromedarius, whilst those of the Swallow and Pebble Prominents, $N$. dictcea and N. ziczac, feed upon poplar and willows. The Buff Tip, Phalera bucephala, is our commonest Notodont, and a fairly destructive forestry pest of oaks. The Chocolate Tip, $P$. curtula, is less common and much smaller; its larvæ devour poplar and sallow.

Cymatophoride.-Closely related to the Noctuidce, though bearing many resemblances to the Notodontidae, this small family is represented in Britain by three species.

The Buff Arches, Thyatira derasa, is a quaintly marked little Moth whose larvæ feed upon Rubus spp.; on the same plants may be found the larvæ of the Peach Blossom, T. batis. The Yellow Horned Moth, Asphalia flavicornis, may often be overlooked, for, evidently recognizing that its colouring is protective, it rests on tree-trunks and old wood. Its larvæ feed on birch and oak. 
SEsIDA.-Clearwings. The majority of species in this family have wings without scales, and many have the tip of the abdomen tufted.

The commonest British species is the Currant Clearwing, S. tipuliformis; less common is the Hornet Clearwing, Trochilium crabroniformis. The larvæ of these species are white, and they burrow into the stems of their food-plant immediately after they are hatched. Hidden within this shelter they spend the whole of their larval and pupal lives.

ZygzenID s.-Burnet Moths. The commonest British species of this family of beautiful Moths is the SixSpotted Burnet, Zygana filipendulce. All the members of the family have somewhat similar brilliant metallic colouring, crimson and greens or blues predominating. The Six-Spotted Burnet is a seaside species. Less common is the scarce Forester, Ino globularia, a little gem, resplendent in bronze or blue-green. Its larvæ feed upon the greater knapweed.

All the Burnet Moths construct peculiar cocoons, which they fasten securely to some support such as a grass stem; they are remarkable for their great powers of movement. The pupa forces itself partly from the cocoon at the time of the emergence of the Moth.

Psychid e.-Bagworm Moths. For the most part small Moths, they are of the greatest interest. The females are wingless, and in some species they are devoid of legs as well, so that they appear like the larvæ of Diptera. The males are usually provided with bipectinate antennæ.

The females live all their lives within "bags "; there also they lay their numerous eggs, and the larvæ, when 



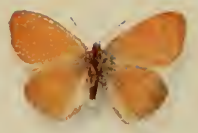

1

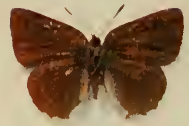

2

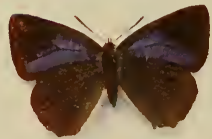

3

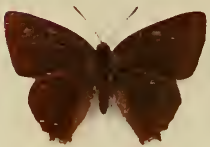

4

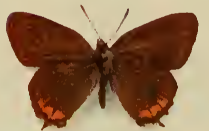

5

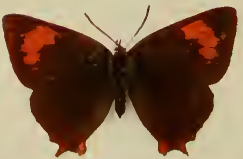

6

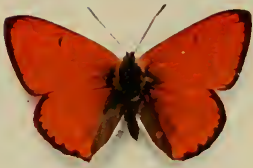

7

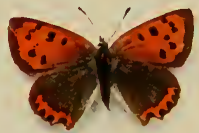

8
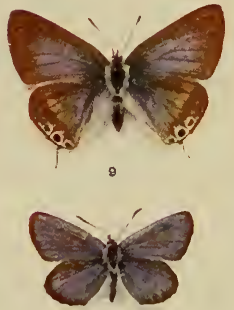

10

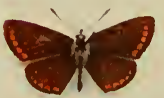

11

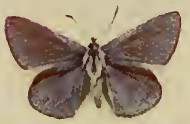

12
1 Cononympha pamphilus Small Heath)

2. Thecla rubi Green Hairstreak

3 Thecla quercus (Purple Hairstreak)

4 Thecla w-album (White-letter Hairstreak

5. Thecla pruni Black Hairstreak

6. Thecla betula (Brown Hairstreak
7. Pelyommatus dispar (Large Copper)

8. Polyommatus phlieas (Simall Copper)

9. L.ycæna gaetica (1.ong-tailed Blue)

10. Lycana Kgon Silver-studded Blue)

11. Lycæna istrarche Brown Argus)

12. Lycrena icarus Common Blue 
they emerge, start life by devouring the body of their mother. Having done so, they feed no more till they have constructed the "bags" in which they are to live. These "bags" vary in form and texture according to the species constructing them. Sometimes they are made of silk; more frequently of sticks or other vegetable material or earth. They are always ingenious. In one species the "bags" resemble shells, but the usual form is a variant of a helix. The sticks of which some of the bags are made are all of the same length, sometimes arranged longitudinally, more often transversely, but always with a regularity and neatness which no human fingers could excel. When the larva has made its " bag" it crawls inside, and there spends the rest of its days, if it be destined to develop into a female. The males are active and short-lived.

Cossides.-The Goat Moths have no proboscis, are covered with a dense vestment of scales, and are all either moderate or large-sized insects.

These Moths are of interest on account of the woodboring habits of the larvæ and their protracted existence in this state. The Goat Moth, Cossus ligniperda, deposits her eggs upon the trunks of willow, poplar, ash, or elm, for choice, and the young larvæ, directly they are hatched, bore into the stems and dwell therein for three years. When fully fed, they are of considerable size, nearly the colour of a boiled prawn, with a broad mahogany stripe down the back. They exude an odour strongly reminiscent of that of the goat, and for this reason they have earned their popular name. It is reputed that in former days these evil-looking larvæ were considered a table delicacy, though it is 
hard to believe the truth of the statement. When fully fed, the larvæ leave their burrows and seek a spot for pupation. They make a hard cocoon of chipped wood and saliva. It is easy to imagine that larvæ so large and long-lived are capable of doing considerable injury to timber trees.

Hardly less injurious are the larvæ of the Wood Leopard Moth, Zeuzera pyrina. They are long-lived and have the same wood-boring habits as Cossus. Fruit-trees are much favoured by them. Fortunately, they are not very common.

HePialid ж.-Ghost and Swift Moths. The species of this family vary tremendously in size; some might aptly be described as minute; others span as much as seven inches from tip to tip of their wings. In colour they are usually sombre, but some of the exotic species, on the contrary, are gorgeous. The South African Leto venus has wings studded with metallic spots; species of the Australian genus Charagia are also brightly coloured.

Of our British species, the Northern Swift, Hepialus velleda, is by no means uncommon; it should be sought among the bracken, on which the larvæ feed. Here it may be mentioned that all the Hepialids are difficult to capture; their flight is low and rapid. More difficult still is it to obtain perfect specimens. The Gold Swift, $H$. hectus, is a much smaller insect, also found near bracken. The Ghost, $H$. pumuli, is the commonest of all. The larvæ feed upon roots of grasses, dock, and ragwort.

A glance at our figures will show that the males differ markedly from the females in colour. That this colouring serves a useful purpose is shown by Sharp, whom we quote: "The male is an insect of exceptional 

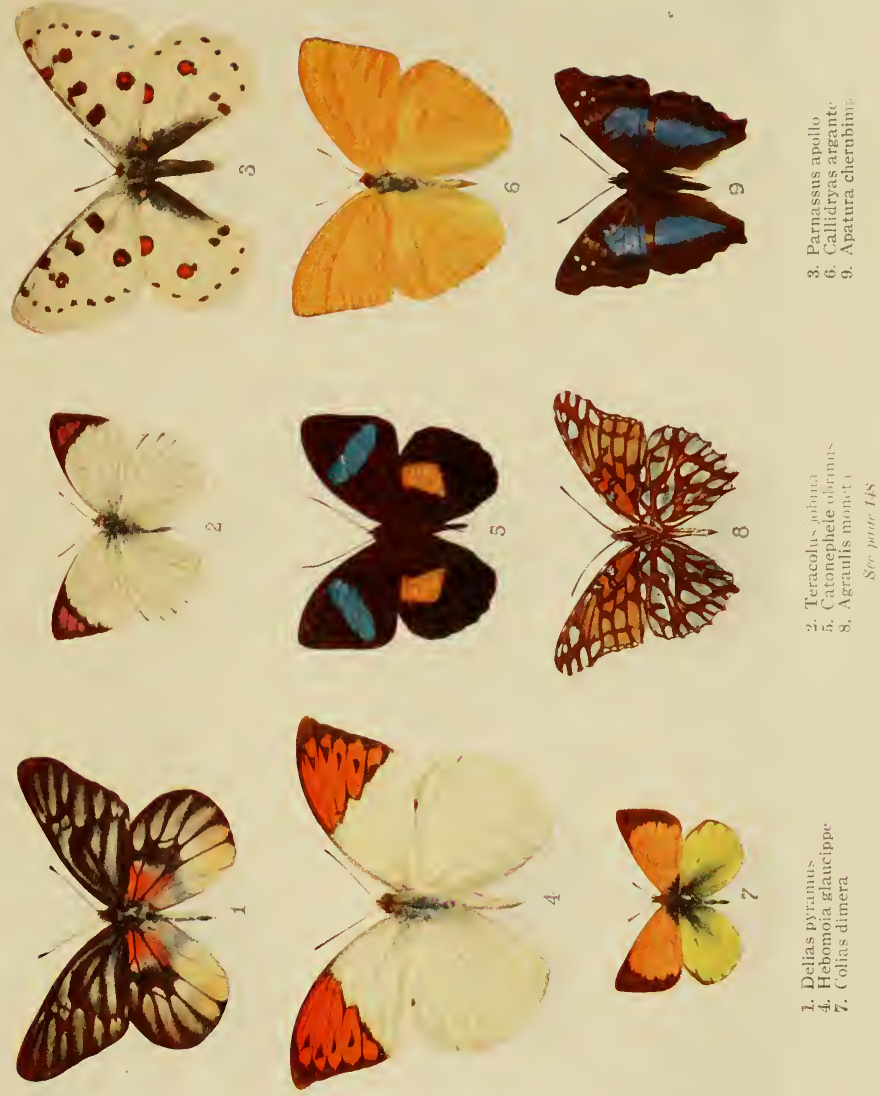

colour, being white above, in consequence of a dense formation of imperfect scales; the female is of the brownish tints usual in Swift Moths. In the month of June the male selects a spot where he is conspicuous, and hovers persistently there for a period of about twenty minutes in the twilight; his colour has a silvery-white, glistening appearance, so that the insect is really conspicuous notwithstanding the advanced hour. Females may be detected hovering in a somewhat similar manner, but are not conspicuous like the male, their colour being obscure; while so hovering they are ovipositing, dropping the eggs amongst the grass. Females that have not been fertilized move very differently, and dash about in an erratic manner till they see a male; they apparently have no better means of informing the hovering male of their presence than by buzzing near, or colliding with him. ... There can be little doubt that the colour of the male attracts the female."

The male of $H$.hectus, according to the same authority, gives off from his swollen hind-legs an odour of pineapple, which attracts the females.

There is very little authentic information concerning the life-histories of species belonging to this family. The larvæ mostly live underground or in wood; the pupæ, which are very elongate, are active.

DrePandDe.-Hook Tips. Nearly all the species of this family have outwardly directed, acute-angled tips to their fore-wings. They are all moderate-sized insects.

In Britain we have half a dozen species, of which the common Hook Tip, Drepana lacertinaria, is the most frequently met with. Its larvæ feed on birch and heather, and are remarkable in possessing a long tubular 
process in place of the usual hind-claspers. The Pebble Hook Tip, $D$. falcataria, is but little less common; its larvæ dwell within shelters which they construct of birch and alder leaves. Cilix glaucata, when at rest, closely resembles bird excrement.

LIMACODIDÆ.-Small, stoutly built Moths, nearly always of an apple-green colour, often edged with brown. There are only two British species, of which Apoda testudo is the commonest. As may be gathered from the scientific name of this insect, the larva is a footless, slug-like creature. Owing to their structure, they glide rather than walk over the leaf-surface on which they feed. This peculiar larval structure, combined with the exceedingly ornate appearance of many species, makes the family of great interest. The cocoons of Limacodids, too, are interesting; they are provided with lids through which the Moths may escape without difficulty.

LASIOCAMPIDE. - The species of this family are all large insects, and are densely covered with scales; antennæ of males pectinate. These Moths are easily recognized; they are, for the most part, heavy insects and clumsy in flight. The commonest British species is the Drinker, Odonestis potatoria, so named on account of the curious dipping flight of the adults, which, when their course is over water, makes them appear to be swooping down for a drink. The females are considerably bigger than the males and a lighter colour. Differences in size between the sexes in this family are common, the females of some species being more than three times the size of the males. The large, brown, hairy Drinker larvæ may be found feeding upon grass in autumn and spring. 

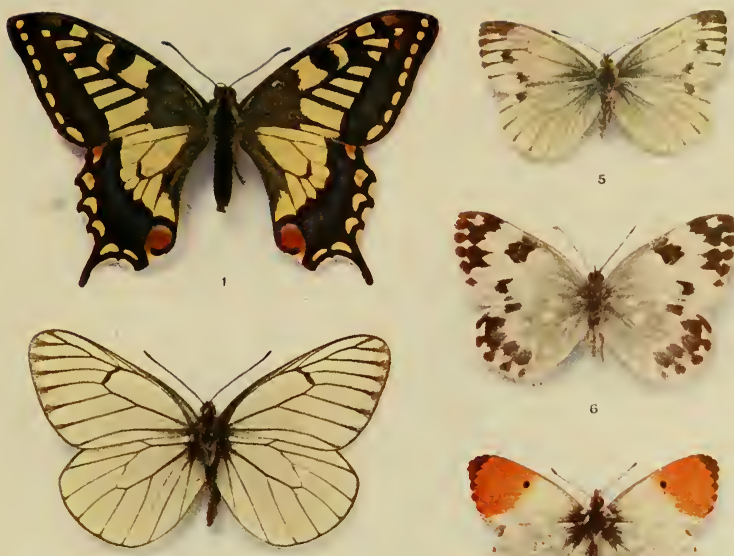

5

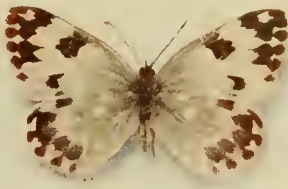

6
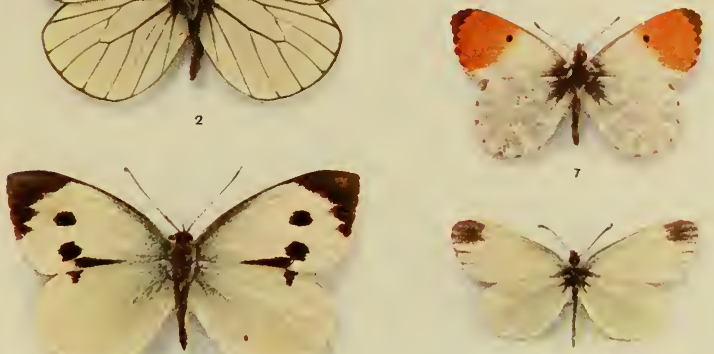

3

8
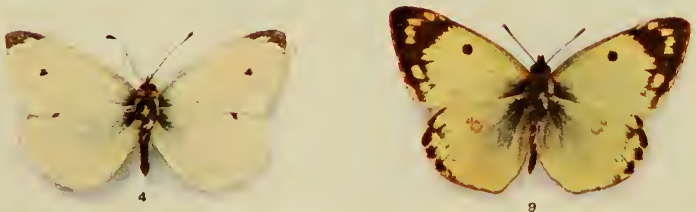

1. Papilio machaon (Swallow Tail)

2. Aporia cratægi (Black-veined White)

3 Pieris brassica Large Garden White

4. Pieris rape Small Garden White

5. Pieris napi (Green-veined White)

6. Pieris daplidice (Bath White)

7. Euchloe cardamines Orange Tip)

8. Leucophasia sinapis Wood White

9. Colias hyale (Pale Clouded Yellow) 

Almost as common is the Lackey, Bombyx neustria. Its eggs and larvæ, at any rate, are only too well known to most fruit-growers. The former are deposited in neat rings round the smaller twigs of some favoured tree, probably an apple, and the larvæ, which hatch in the spring, are very destructive to the foliage. There is another closely allied Moth, known as the Ground Lackey, B. castrensis; it is a somewhat local insect and is not injurious, for its larvæ feed on seaside plants.

The Oak Eggar, B. quercus, is one of our handsomest Moths. The females, as is usual, are larger than the males and paler in colour. There is, however, considerable colour variation in this species; the oak-fed larvæ produce paler-coloured adults than those fed upon heather. This Moth is supposed to take its peculiar popular name from its close-spun cocoon, which is not unlike egg-shell in appearance. The larval hairs of this species are easily shed, and are particularly irritating to the skin. The Fox, B. rubi, is so called on account of the colouring of the male; the females are grey. As its name implies, it is a lover of bramble in the larval state. The Lappet, Lasiocampa quercifolia: this handsome Moth is not common except in the South. It is somewhat inert, but escapes attention as it rests on some branch, because it very closely resembles a dead leaf. Its larvæ feed upon bramble plum, sloe, amongst other plants. Of the December Moth, Pocilocampa populi, it is said that it sometimes remains in the pupal state for several years.

ENDromidz.-The British Moth popularly known as the Kentish Glory, Endromis versicolor, is the sole species of the family. It is by no means common, but 
may be taken by day in birch woods. The larvæ are almost destitute of hairs; they feed on birch, and superficially resemble Sawfly larvæ.

LYMANTRIID \&.-This is a most interesting family of sombre-coloured Moths, many of which have highly injurious larvæ. The Moths are mostly white, grey, or brown, the first-named colour being the most frequently met with. The larvæ are hairy and often beautifully coloured; the hairs of most species are irritating to the skin. It is said of the larvæ of the Nun, Psilura monacha, and of the Gipsy Moth, Ocneria dispar, that when newly hatched they have hairs provided with air-bladders. These air-bladders are supposed to so lighten their owners that, by launching themselves into the air from a height, they are distributed for a considerable distance by air-currents. Hair forms a considerable portion of many Lymantriid cocoons, and, more unusual still, the pupæ of some species are hairy.

We have about a dozen species in Britain, and of these the Vapourer, Orgyia antiqua, is very common even in London. Although common, the Vapourer is well worth a little attention. As our figure shows, there is a striking difference between the sexes. The male is strong on the wing and an active insect; the un-moth-like female is a small, hairy, heavy-bodied creature, with wings so minute as to be useless for flight. She rarely strays far from her cocoon, and on it she often lays her eggs. The larvæ are among the most beautiful of our native species, of a peculiar bluish-grey colour with a paler strip down the back, on which there are rows of red dots; they bear a couple of tufts on their heads and four yellow tufts on their 

PLATE XXX

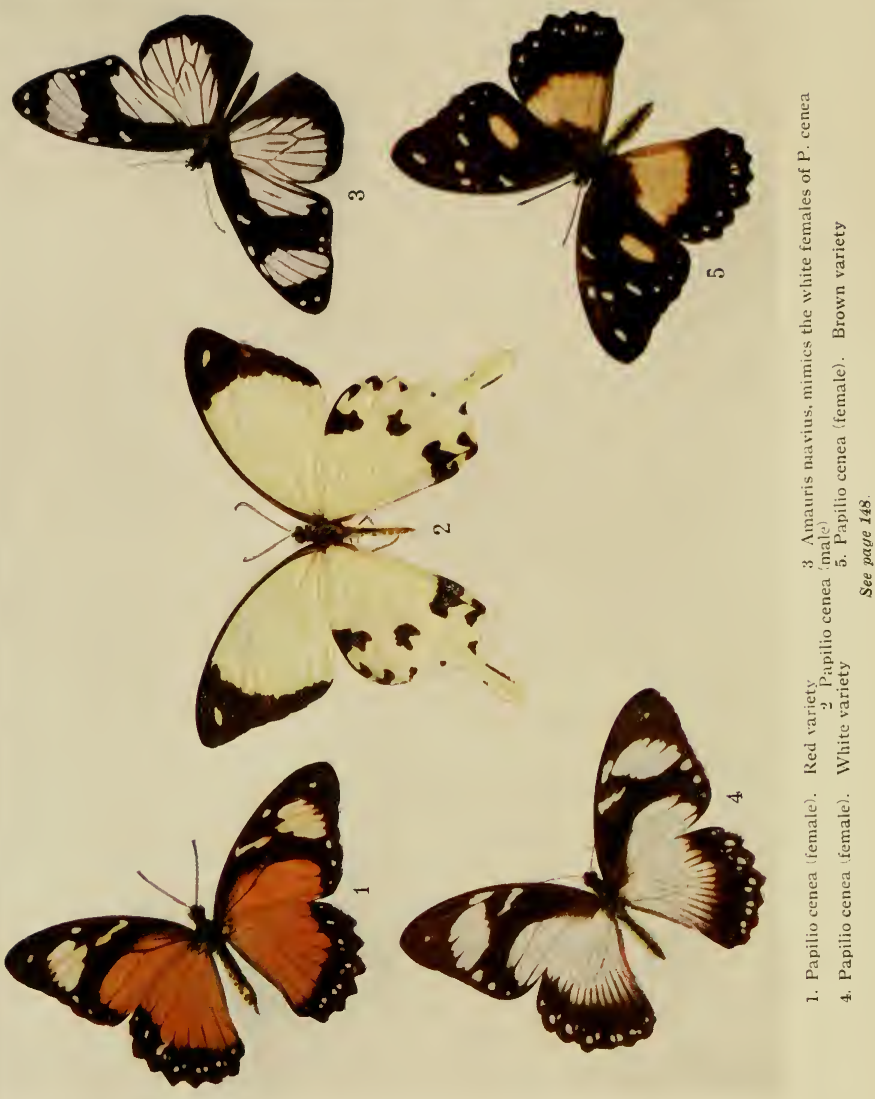




\section{MOTHS}

backs, in addition to numerous smaller tufts. They are catholic in their tastes, and there is little vegetation that they will not devour. Occasionally, even in London squares, the trees are completely defoliated by these voracious larvæ, and were it not for the activities of an Ichneumon parasite they would speedily increase to an alarming extent.

The Gold Tail, Porthesia similis, is equally common, though not a town-frequenting species. A glance at our figure will show how appropriately this insect is named. The larvæ may be found on hawthorn and various fruit-trees in the summer; they are prettily marked with black and red.

The Black Arches, Psilura monacha, is also known as the Nun. It is not common in Britain, but on the Continent, and in Germany especially, it is a serious forestry pest, for the young larvæ feed upon the leaves of many trees, but especially upon those of the Coniferce. The Pale Tussock, Dasychira pudibunda, also known as the Hop Dog, because it does a considerable amount of damage to hops, is a noted forestry pest in France.

The most notorious Lymantriid, however, is the Gipsy Moth, Ocneria dispar. Exactly fifty years ago an American enthusiast who was studying various Lepidoptera, with a view to making use of their silk, accidentally released some imported Gipsy Moths. For many years the insects merely held their own; then they seemed to awaken to a new life; they increased enormously, though they did not spread quickly. Every effort was made, and is being made, to keep them in check; a million dollars a year are spent on 
their control. Parasites and enemies have been imported from Europe, but still the Gipsy Moth holds its own as America's greatest forestry pest. Nearly as injurious is the Brown-Tail Moth, Euproctis chrysorrhoca, also imported from Europe. The adult is not very dissimilar to the Gold Tail, but brown takes the place of gold on the tip of the abdomen. A near relative of the Pale Tussock, known as Dasychira rossii, is noteworthy because it inhabits the Arctic regions.

HyPSID 2 .-A small family of tropical and subtropical Moths, which do not resemble any European species. Most of them are straw-coloured, with white dots or lines.

ARCTIDE.-This is a large family, and many of the species are highly ornate. Everyone knows the "woolly bears," those long-haired active larvæ which may be met with on all manner of vegetation in the early summer, or may be seen walking rapidly over gardenpaths or even roads. They are the larvæ of the Garden Tiger, Arctia caia. The long hairs of these larvæ are not without their uses; they serve as a protection for their owners against many enemies, and they are used to form the cocoon, for which purpose the owner bites them from its body before pupating. The Cream-Spot Tiger, A. villica, is a very similar insect to the Garden Tiger in appearance, though easily distinguished. Much more similar, however, are the larvæ; those of the former species may be known by their red heads, those of the latter species are black. Both will eat almost any vegetation.

The Ruby Tiger, Spilosoma fuliginosa, is quite a different-looking insect-in fact, this genus bears some 


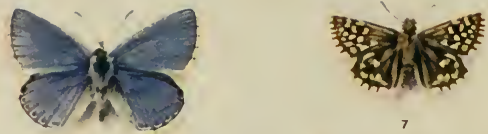

7
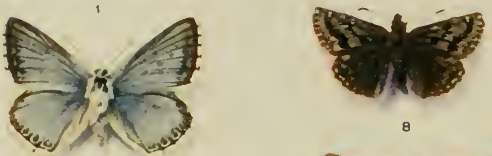

8
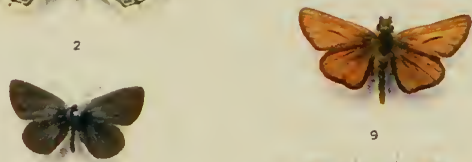

9

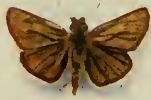

IO
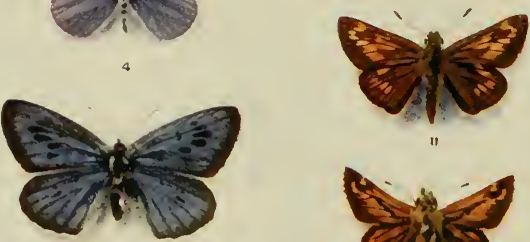

5

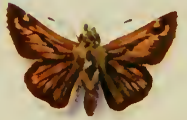

12
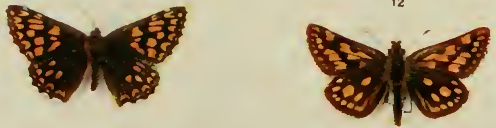

13

1. Lycæena bellargus (Clifden Blue)

2. Lyeæna corydon Chalk-hill Blue)

3. Lycæena minima (Little Blne)

๘. Nisoniades syrichthus malvæ (Grizzled Skipper)

4. Lycæna argiolus (Azure Blue

8. Nisoniades tagos (I)ingy Skipper)

9. Hesperia thaumas (Small Skipper)

5. Lycæena arion (Large Blue)

6. Nemeobius lucina (Duke of Burgundy Fritillary

10. Hesperia actæon (I,ulworth Skipper)

11. Hesperia sylvanus (1-arge Skipper)

12. Hesperia comma (Pearl Skipper)
13. Cæterocephalus palæmon (Checkered Skipper 
resemblance to certain species of Hypsidce. It is usually met with on high ground, and heather is a favourite food-plant of the larvæ. The Buff and White Ermines, S. lubricipeda and S. menthastri, are common everywhere. The Buff Tiger, Nemeophila russula, is a daintily marked insect, a dweller on moorland. We figure the male. Its larvæ feed on heather and heath, and hibernate through the winter. The Scarlet Tiger, Callimorpha dominula, though a member of a different subfamily, bears considerable resemblance to the Garden Tiger. The Cinnabar Moth, Euchelia jacobcea, has a livery which, in colour, is strangely reminiscent of the Burnet Moths, though there the similarity ends. Its larvæ, black with conspicuous yellow bands, are common on ragwort, and literally cover their food-plants, for they are gregarious.

The little Muslin Moth, Nudaria mundana, is a frail creature with feeble powers of flight. Its larvæ feed upon lichen, a favourite food of the species of this subfamily. The "Footmen," of which we figure three species, are all light-bodied, somewhat narrow-winged Moths. They fly by day, and their livery is usually some shade of yellow marked with black. The Common Footman, Calligenia lurideola, is not easy to find in its larval state, for the insects closely resemble their food-plants in colour. Less common is the Rosy Footman, Calligenia miniata, and quite local the FourSpotted Footman, Gnophria quadra, which, by the way, is not spotted in the male; our figure is of a female. The larvæ of both species feed on lichens.

Geometrid a.-This is an immense family, and, curiously enough, the larvæ are usually better known 
than the adults. The former are known as Loopers or Geometers on account of their curious looping gait, necessitated by their anatomical structure. They possess thoracic legs, a pair of claspers, and but one other pair of abdominal legs, on the ninth segment. When walking, they clasp their support with the thoracic legs and draw up their abdominal legs so that their bodies are looped; then, after making firm with their hind-legs, they advance the fore-part of the body and repeat the operation. When at rest these larvæ assume curious attitudes. Being thin and hairless and, some of them, coloured like a dry twig, they frequently clasp their support with their hind-legs and rest at an angle of about 75 degrees thereto. When in this position there is always a life-line of silk from the larva to some near-by twig. This silken thread serves a double purpose: it lends additional support to the larva, and when danger threatens the insect can drop from the tree and remain suspended by its thread till the danger be past. After an interval the larva returns to its original support by means of the thread. Many Loopers, when at rest, bear a remarkably close resemblance to twigs, green or dry, according to their colour. The adults are all night fliers; they are somewhat delicate insects, but nearly all of them are provided with relatively large wings, with the exception of the females of certain species, which are wingless or nearly so. The family includes the numerous Moths known to entomologists as "Pugs," "Carpets," and "Waves," etc. Many species are decidedly injurious to crops and forest trees.

Lack of space forbids even a cursory view of the 
PLATE XXXII

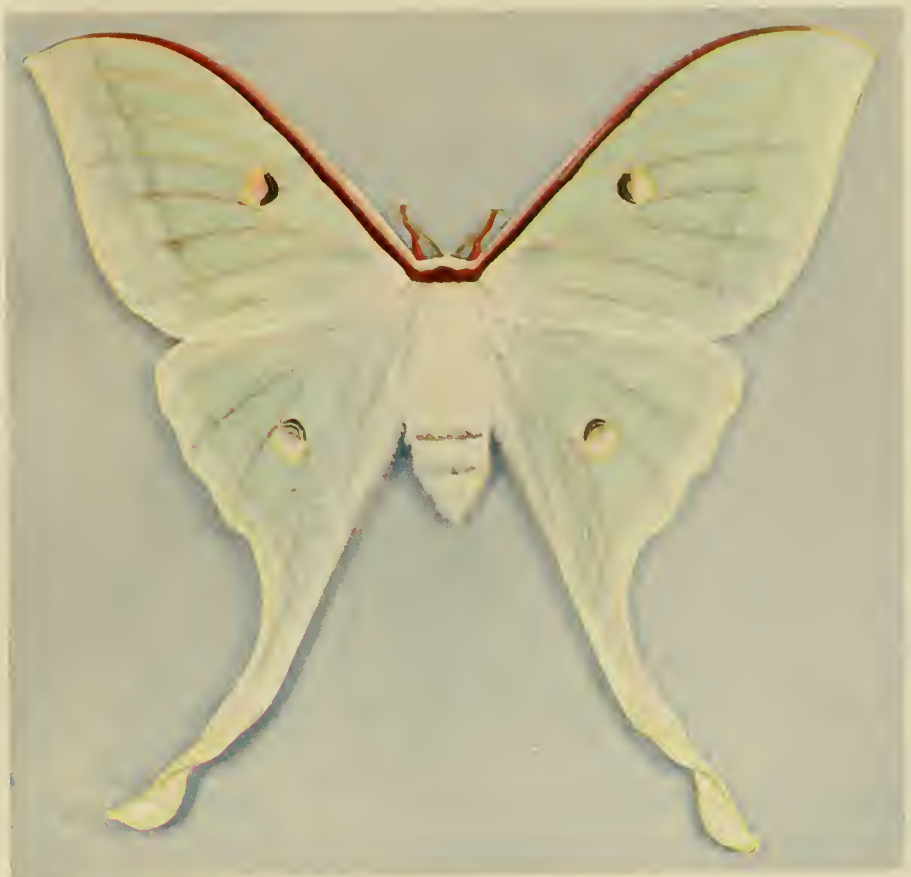

ACTIAS SELENE 

fifty-seven species we figure in colour, and these are but a fifth of the British species.

The Early Thorn, Pericallia bilunaria, is interesting because it belongs to a genus whose larvæ, when resting, resemble thorns or small branches. They should be sought on hawthorn and oak in the summer. The Pale Brindle Beauty, Phigalia pedaria, is a species with wingless females. The females of this order are much more active than are those of the Vapourer Moth. Many of them ascend the highest trees, and it has even been asserted that the males carry them thence. Oak and beech are the favourite trees of the female and their larvæ.

The Magpie Moth, Abraxas grossulariata, is often a serious pest of gooseberries and currants, and on that account is sometimes called the Gooseberry and Currant Moth.

The most notorious pests of the family are the Mottled Umber, Hybernia defoliaria, and the Winter Moth, Cheimatobia brumata. Both of them are well named; defoliaria speaks eloquently of the Mottled Umber's defoliating propensities, and the Winter Moths are on the wing in November and December. The females of the former species are wingless; those of the latter have wings only slightly developed. This lack of wings does not appear to affect the geographical distribution of the Winter Moth, for it is found almost everywhere in Europe and in North America.

NoctuIDs.-Another unwieldy family of Moths, containing a large number of species which are very similar to one another. Often, in such cases, the larvæ are quite distinct, a statement which may be verified by 
an examination of the larvæ and pupæ of Acronycta psi and A.tridens. The larvæ of some of the Dart Moths (Agrotis spp.), on the other hand, are so much alike that it is impossible to identify them with certainty, though the Moths themselves are quite distinct.

As may be surmised from the name of the family, nearly all these Moths are night-fliers; the larva, too, of many species remain hidden by day and come out at night to feed.

We figure no less than sixty-five Noctuids, but a tithe of which we can mention here.

The Antler Moth, Charceas graminis, is an exception to the usual Noctuid rule, in that it often flies by day. It is exceedingly common and very prolific, and, seeing that its larvæ feed upon grasses, it is not surprising to learn that in certain seasons it becomes a serious pest. Very frequently we read of plagues of Caterpillars which devour all the herbage of our pastures; usually the culprits are the larvæ of the Antler Moth.

The Cabbage Moth, Mamestra brassica, is another serious pest, though, fortunately, it is not so prolific as the last-named species. Its larvæ refuse little that is green, but appear especially partial to cruciferous plants, cultivated for choice.

The genus Agrotis is noted for its evil-doers, and every husbandman knows the Turnip Moth, A. segetum, and the quaintly named Heart and Dart, $A$. exclamationis. The larval attacks of these species are exceedingly insidious, for they are subterranean feeders upon roots of grasses, cruciferous plants, and the like. Very frequently the total failure of the crop is the first indication to the farmer that anything is amiss, for the larvæ 
PLATE XXXIII

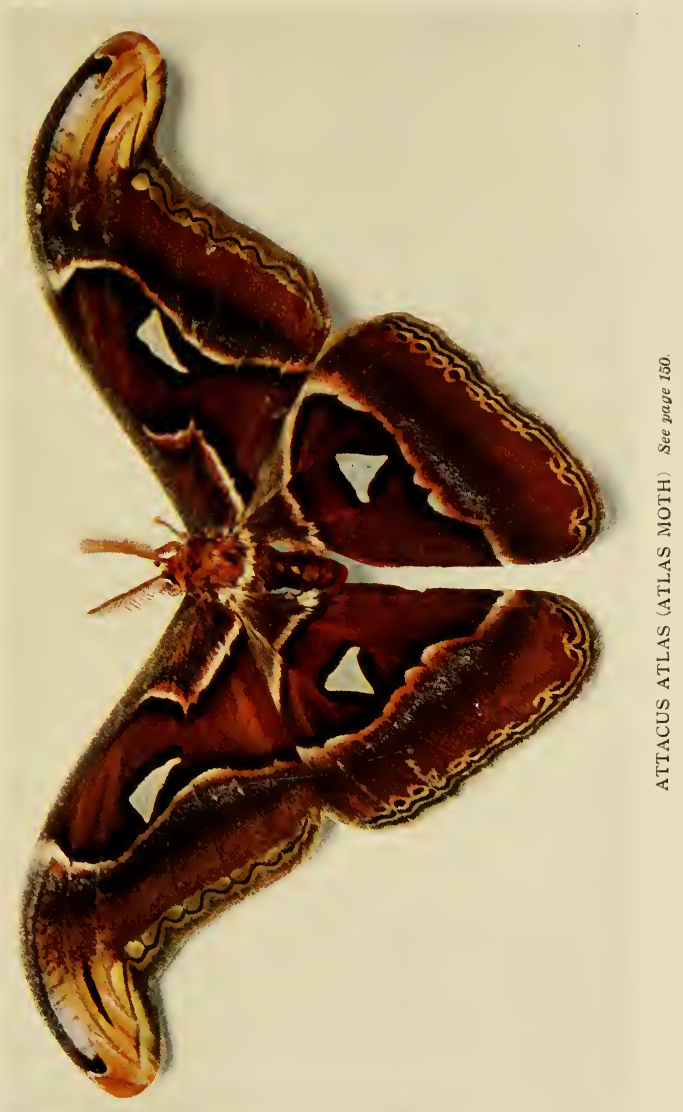



rarely show themselves. A near relative, the Australian Bugong Moth, A. spina, was formerly used as an article of food by the natives.

Very interesting are the Plusias; they are frequently devoid of the usual complement of larval legs, and on that account they progress in a manner very reminiscent of the Geometers. This trait has earned them the name of Semi-Loopers. Many of the Moths have wings, beautifully marked with metallic gold or silver spots and blotches. The Gold Spot, Plusia festuca, affords but a hint of the lovely ornamentation to be found in some exotic species.

The Orange Underwing, Brophos parthenias, is a diurnal Moth, and is on the wing in early spring. Its near relative, $B$. notha, has the peculiar habit for a Noctuid of spinning two or three leaves of its foodplant (aspen) together and living within the shelter. When fully fed, it seeks some soft wood, into which it bores, there to pupate. Before doing so, however, it takes the precaution to close the hole by which it has entered with a double door of silk.

In a family containing so many injurious species, it is pleasant to mention one which is useful. The South European Noctuid, Erastria scitula, as a larva preys upon the Peach Scale, Lecanium olece. The larvæ are small, the scales are large. The former eagerly devour the latter, and eventually add to the scale by means of silk, so that it forms a shelter beneath which they can pupate.

The story of the Noctuids could be unfolded to considerable length; from the giant American Erebides, which may span as much as eight inches from tip to 
tip of their wings, to the most minute forms, all are interesting and many of extreme beauty. We must, however, leave the family with the remark that the larvæ of the Marbled Beauty, Bryophila perla, share with certain of the Arctiids the very uncommon habit of feeding upon lichens, and, as is usual in such cases, their colouring closely resembles that of their foodplants.

Pyralme.-An enormous family of small or mediumsized, long-legged, somewhat fragile Moths. In Britain about a hundred and fifty species are known; many of them are injurious, and some are among the most interesting of all the Lepidoptera.

The Scoparias, of which we figure the Hoary Grey, Scoparia dubitalis, are, like the species we mentioned above, lichen-feeders. The Ephestias, and notably the Flour Moth, Ephestia Kühniella, are many of them serious pests of stored grain, which they not only eat, but damage by matting together with their silken webs. A species of Ephestia also attacks dried figs, and its larvæ are by no means strangers to our dinner-tables. The Meal Moth, Pyralis farinalis, is very similar in habit to the Flour Moth.

The Grass Moths of the genus Crambus are very common. They may be seen in thousands during a walk through meadowland in summer-little palecoloured Moths, which only seem capable of flying a short distance without resting. Their pointed heads, owing to the shape of their palpi, and their method of resting with wings tightly folded over their backs, render them unmistakable.

Of the British Pyralids, the most remarkable are the 


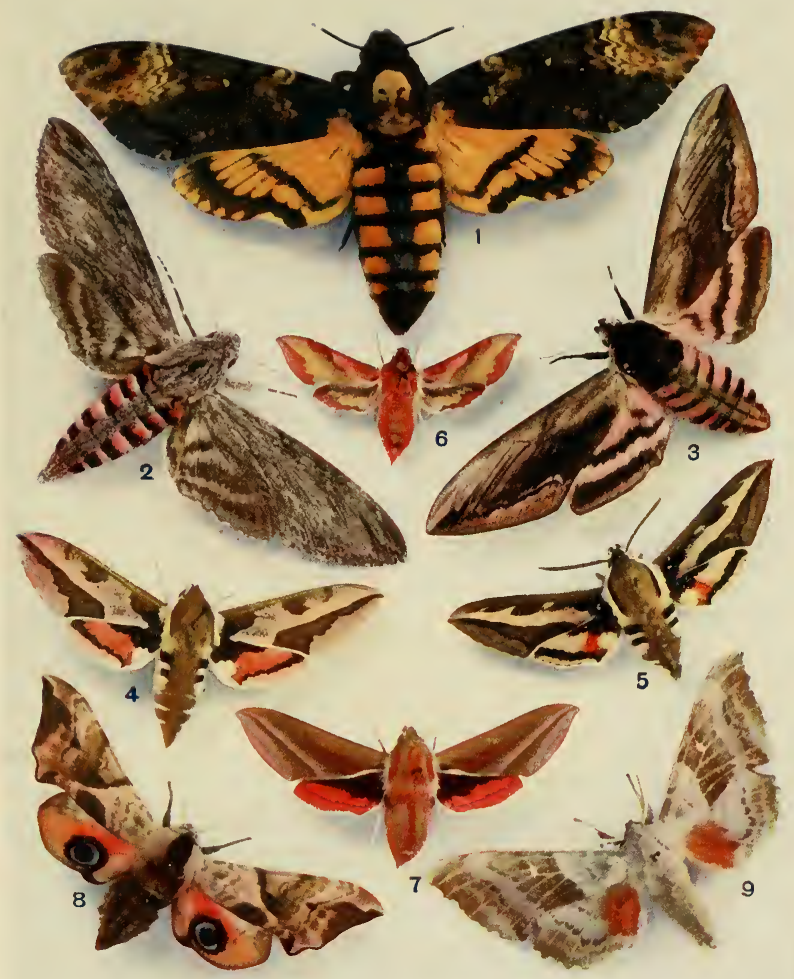

1 Acherontia atropos 2 Sphinx convolvuli

3 Sphinx ligustrı
+ Deilephila euphorbice 5 Deilephila galii

4) Charocampa porcellu, See page 151
7. Chærocampa elpenor

3. Smerinthus ocellatus

9. Smerinthus populi 

China Marks Moth--we figure one species, Hydrocampa stagnata. Their larvæ are aquatic, and not only so their life-histories are of absorbing interest. For a very full and interesting account of the life-history of the Brown China Marks Moth, $H$. nympheata, the reader is referred to Miall's " Natural History of Aquatic Insects." In brief, the Moths deposit their eggs upon the leaves of some aquatic plant. When the larvæ emerge they tunnel into the leaves and appear oblivious of the water which surrounds them. After a moult the larvæ forsake their burrows and make dwellings by cutting out pieces of leaf and fastening them to the under-sides of other leaves. These shelters are not waterproof, but the water causes the larvæ little inconvenience. More moults occur, and hibernation takes place below water. In the spring the larvæ each take a couple of pieces of leaf and fasten them together in the shape of a double convex lens. At this stage the water seems to trouble them for the first time, and they contrive to make their lens-shaped shelters watertight. In them they complete their development.

Despite their aquatic environment, these larvæ are not provided with gills or any organs for respiration below water; they apparently breathe through their skins. In certain closely related, though not British, species the larvæ are provided with branchial gills. The larvæ of the Small China Marks Moth, Cataclysta lemnata, live in little cases which they form by binding together the leaves of duckweed with silk.

Of all the Pyralids, the most extraordinary is the genus Acentropus. " This insect is apparently the most completely aquatic of all the Lepidoptera, and was for 
long associated with the Trichoptera in consequence of its habits and of the scaling of the wings being of a very inferior kind. The males may sometimes be found in large numbers fluttering over the surface of shallow, but large, bodies of water; the females are rarely seen, and in some cases have no wings, or have these organs so small as to be useless. The female, it would appear, comes quite to the surface for coupling, and then takes the male beneath the water. The larvæ have the usual number of Lepidopterous feet, and apparently feed on the leaves of plants below water, just as Lepidopterous larvæ ordinarily do in the air. They have no trace of gills, and their mode of respiration is unknown."

Species of the genus Galleria -there are three in Britain-are much dreaded by bee-keepers. These Moths enter the hives at night and deposit their eggs near the combs. The larvæ greedily devour the wax, and at the same time spin tough silken webs wherever they go.

Pterophorid ж.-The Plume Moths are easily distinguished on account of their deeply divided wings, the hind-wings especially-the fore-wings are sometimes nearly entire, and in one genus, Agdistes, the wings are quite undivided. These are delicate little Moths, many of them white, and their chief interest lies in their coloured, soft, and hairy pupæ. There are thirty species of these little Moths in Britain.

TORTRICID E.--Minute Moths whose larvæ all live inside their food, which may consist of either fruits, seeds, roots, or leaves. When leaves are the food, the larvæ roll them most ingeniously and fasten them with 


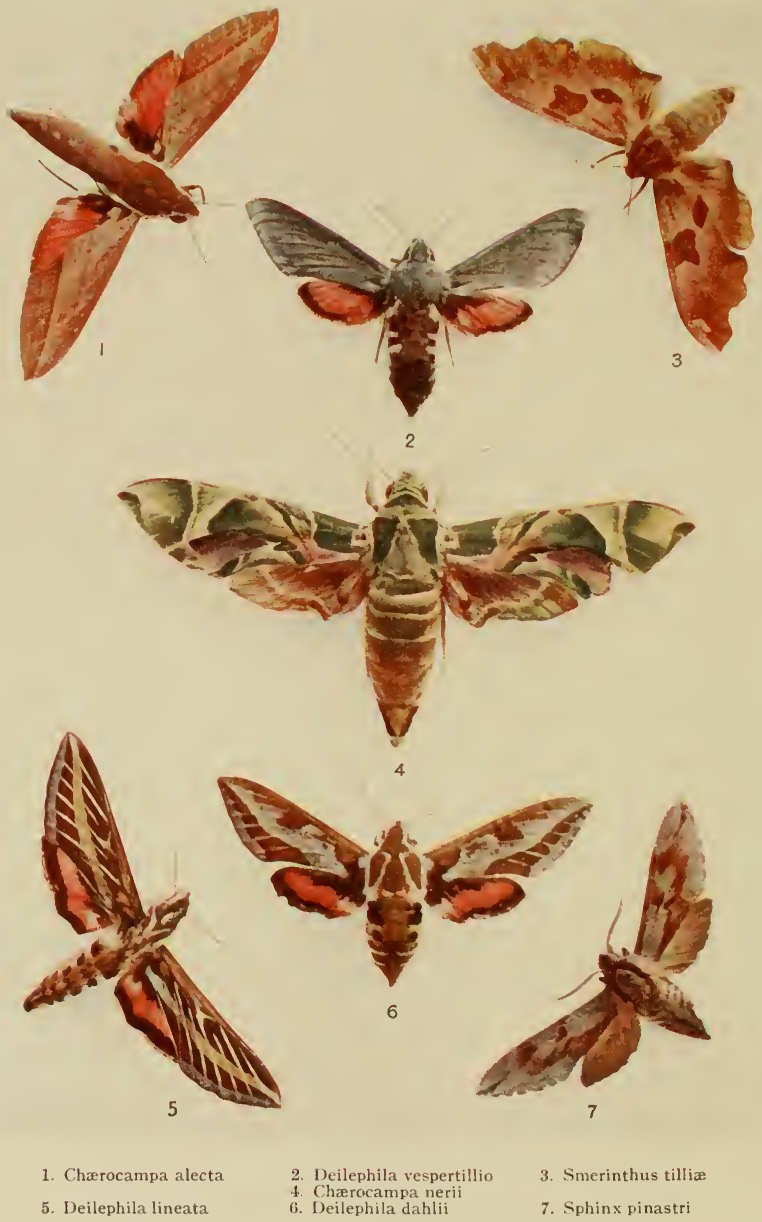
silk in such a manner that they will remain in a permanently rolled state. As the-larvæ are all very small and the leaves are often large, the exact methods by which they accomplish their object have been the cause of considerable conjecture. Of the "leaf-rollers," the commonest, in Britain, are the Green Tortrix, T. viridana, a not inconsiderable pest of oak, and T. ribeana.

The most serious pest of the family is the Codling Moth, Carpocapsa pomonella. The female lays her eggs on young leaves of apple, about May, and the larvæ, when they hatch, bore into the young fruit at the calyx end and penetrate to the core. Here they live and feed and collect a nauseating mass of frass which ruins the fruit. When fully fed, the larvæ tunnel their way out of the fruit and pupate beneath the loose bark of the apple-tree. The closely related $C$. splendana infests acorns, and $C$. juliana Spanish chestnuts.

The most curious of these Tortricidce are those whose larvæ live in the seeds of Euphorbias and give rise to the so-called " jumping beans." Carpocapsa saltitans, for instance, lives in the seeds of Croton colliguaja. It hollows out most of the interior, from one end to the other, and by various movements, which have not yet been observed, it causes the centre of gravity to shift from time to time and the seed to move.

TineID ж.-A very large family-there are seven hundred British species-of minute Moths. Their hindwings, which are small, are usually fringed.

Perhaps the most remarkable fact about the majority of species of this family is the nature of their food. The larva of the Clothes Moth, Tinea tapetzella, feeds upon clothes and builds cases of its food-material in 
which to dwell. The larvæ of the Woollen Moth, T. pellionella, have similar habits, whilst those of $T$. biselliella appreciate the same food, but do not make cases. Of the exotic species, T. vastella feeds on the horns of living antelopes, and another species " has been found in abundance in the hair of a live Sloth, Bradypus cuculliger, under circumstances that render it possible that the larva feeds on the creature's hair, though it may feed on minute vegetable matter found in the hair."

Many of the Tineids are "leaf-miners." The larvæ, quite early in life, burrow between the upper and lower epidermis of the leaf of their food-plant. There they feed on the leaf-tissues, secure from most enemies, and there also they pupate. The common Oak-Miner, Nepticula ruficapitella, is frequently seen, or rather the workings of its larvæ.

The Small Ermine, Hyponomeuta padella, a beautiful little white Moth with black markings on the forewings, is better known by the activities of its larvæ than by the appearance of the adults. Its gregarious larvæ are known as " tent-caterpillars" from their habit of spinning dense silken webs on the branches of their food-plants-apple and hawthorn. Within these tents they dwell when young, and to their shelter they retire when alarmed in later life. 


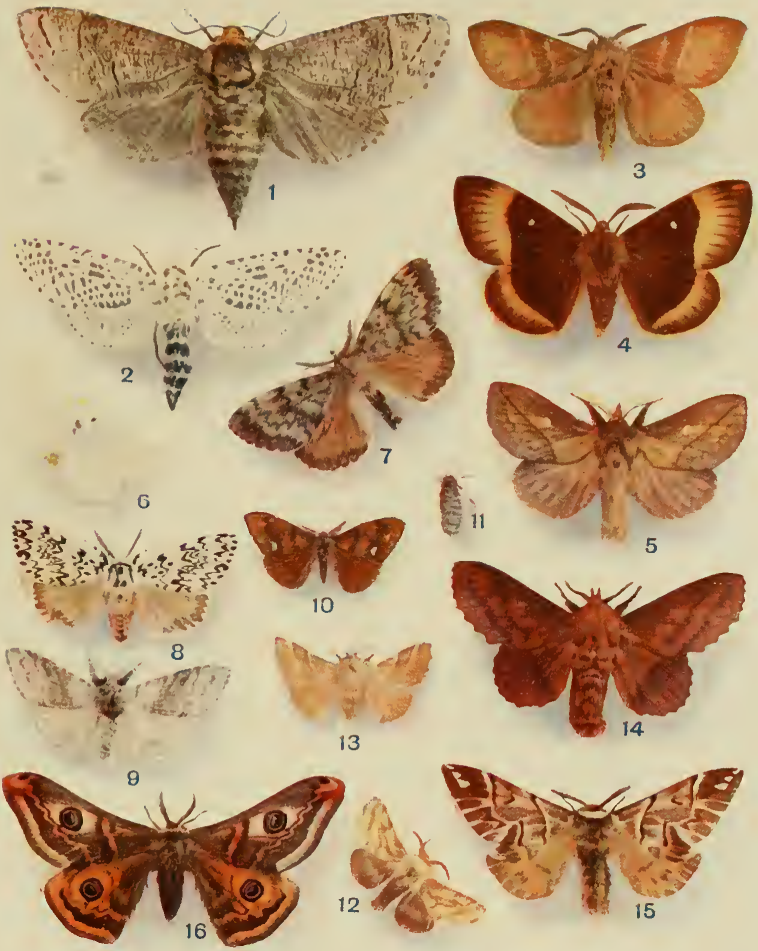

1. Cossus ligniperda

2. Zeuzera pyrina

3. Bombyx rubi

4. Bombyx quercus

5. Odonestis potatoria

6. Porthesia similis
7. Ocneria dispar

8. Psilura monacha

9 Dasychira pudibunda

10. Orgyia antiqua

11 Orgyia antiqua (female)
12. Bombyx castrensis

13. Bomby $x$ neustria

14. Lasiocampa querifolia

15. Endromis versicolor

16. Saturnı pavonia (male) 



\section{CHAPTER VI \\ COLEOPTERA AND STREPSIPTERA}

\section{Order Coleoptera, or Beetles.}

BeEtLes are four-winged insects; their fore-wings (elytra) are usually hard and horny, and serve as shields for the membranous hind-wings. In almost every case the hind edges of the fore-wings are placed together when not expanded, so as to form a suture down the insect's back. Mouth-parts designed for biting; metamorphosis complete.

Although there can be few readers of these pages who do not possess a general idea of Beetle anatomy, as far as externals are concerned, at the same time, mainly on account of their mode of life, Beetles are not nearly such familiar creatures as Flies or Moths. For the most part, they are ground dwellers, and the Coleopterist must needs know something of their habits to be able to come upon them. They form, in fact, by far the largest order of insects; about seventy thousand species are known, and of these more than four thousand are native to this country.

Coleoptera may be found of every conceivable form; some of the most bizarre insects belong to this order. In colour they vie with the Butterflies and Moths, some of the Lamiidae being brilliantly attired; certain of the Weevils are of exquisite metallic hue, veritable gems 
of the insect world; the Rose Beetles, the Ladybirds, the Leaf Beetles, and many others, cannot fail to arouse our admiration in the adornment of their armour. On the other hand, the species of several families are nearly all black, or at any rate of sombre shades; the Tenebrionidce and the Bostrychidce are of this nature. Some Beetles have elytra so smooth that they have the appearance of being polished daily; others have pits, more or

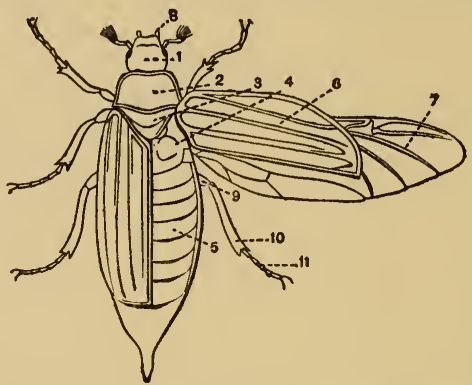

Fig. 7 - External Anatomy of a Beetle. (Upper Side.)

1, Head stretched forward; 2, prothorax; 3, mesothorax, scutellum; 4 , metathorax; 5 , abdomen; 6 , anterior wing (elytron) of right side, turned forward; 7 , posterior wing of right side, expanded; 8 , maxillary palps; 9 , femur of third right leg; 10, tibia of third right leg; 11 , tarsus of third right leg.

From "Zoology of the Invertebrata," by A. E. Shipley.

less deep all over their surface or arranged in longitudinal rows, or in some other definite pattern. Other species have furrowed or crinkled or hairy elytra; indeed, it is hard to set a limit on the various forms which this vast order exhibits. In size there is every stage between the tiny Sphcerida, of which $S$. acaroides occurs in Norfolk, no longer than one-fiftieth of an inch, or Nanosella fungi, but half that size, up to the giant 

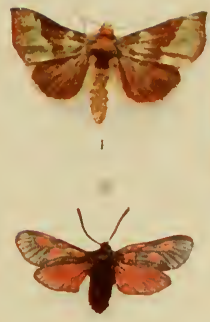

3

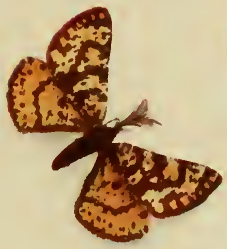

6

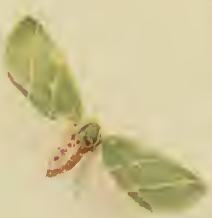

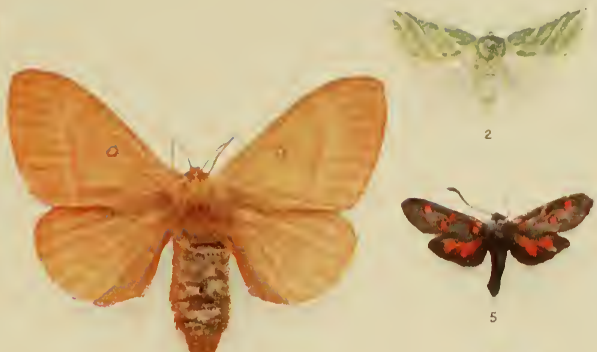
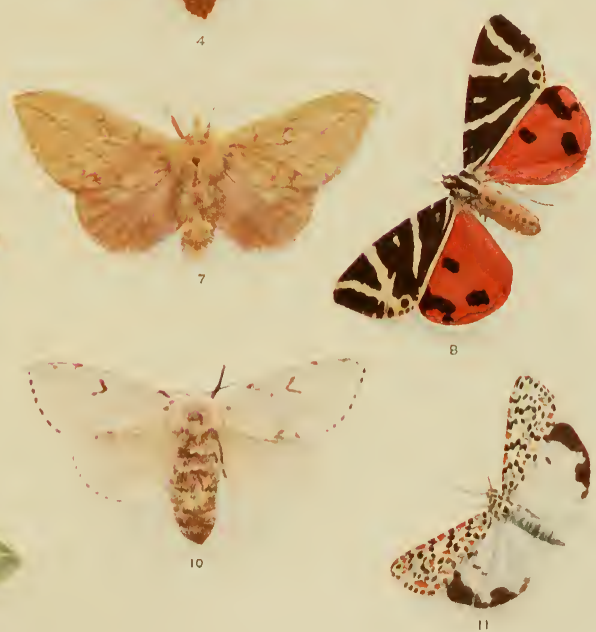

1. Plusia chrysilis

3. Zygæna exulans

6. Eurranthis plumistaria

9. Hylophila bichlorana

4. Bombyx quercus Female

7. Odonestis potatoria (Female) 10. Ocneria dispar Female
2. Halias prasinana

5. Zygæna lavandula

8. Callimorpha Hera

11. Utethesia pulchella 

Goliath Beetles or the South American Prionids, Titanus giganteus, which may measure between two and three

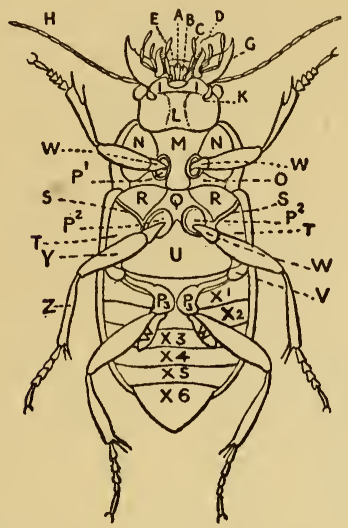

Fig. 8-External Anatomy of a Beetle. (Under Side.)

$A$, Ligula; $B$, paraglossus; $C$, labial palp; $D$, maxillus, or lower jaw; $E$, labrum, or upper lip; $G$, mandible, or jaw; $H$, antennæ; $I$, mentum, or chin; $K$, buccal fissure; $L$, gula; $M$, prosternum; $N$, prosternal episternum; $O$, prosternal epimeron; $P$, coxæ; $Q$, mesosternum; $R$, mesosternal episternum; $S$, mesosternal epimeron; $T$, metasternal episternum; $U$, metasternum; $V$, metasternal epimeron; $W$, trochanters; $X I$ to $X 6$, segments of abdomen; $Y$, femur; $Z$, tibia. From "Common British Beetles," by C. A. Hall. inches in length.

The habits of Beetles are as varied as their forms. There are species which are perfectly adapted to an aquatic life in the adult
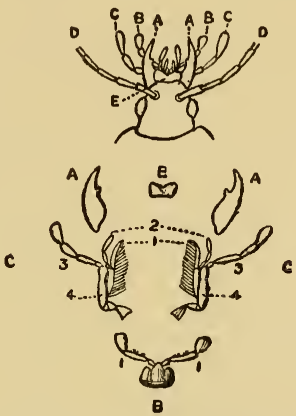

Fig. 9.-Head and Mouth Parts of a BeEtle.

$A$, Mandibles; $B$, labial palpi; $C$, maxillary palpi; $D$, antennæ; $E$, labrum. 1, Lacinia; 2, galea, or palpiform lobe; 3 , palpi; 4, stipes.

From "Common British Beetles," by C. A. Hall.

stage; others dwell in decaying animal or vegetable matter; others are purely leaf-eaters; others, again, are carnivorous. The mode of life of the larvæ has not 
been so thoroughly studied in this order as in, say, the Lepidoptera; sufficient is known, however, to render it quite impossible to sketch one larval history which will apply to all. The most curious larvæ, in point of view of
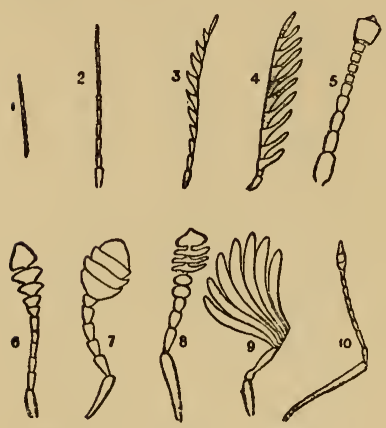

Fig. 10.-Types of Antennas.

1, Moniliform (beaded); 2, filiform (threaded); 3 , serrate (saw-like); 4, pectinate (comb-like); 5, capitate (with a head); 6 and 7, clavato (clubbed); 8, perfoliate clavate; 9 , lamellate (plated); 10 , geniculate (elbowed).

From." Common British Beetles," by C. A. Hall.

their behaviour, are those of the Oil or Blister Beetles (Meloidce); but as they are fully described elsewhere (p. 21), the point need not be laboured here.

It is natural that so immense an order as the Coleoptera should be considerably subdivided; it is unfortunate that there should exist so much difference of opinion concerning its correct subdivision. We have elected to follow Sharp, who recognizes six series.

SERIES 1. LAMELLICORNIA. - The terminal joints of the antennæ are leaf-like, or at least broader than the rest, and when at rest and not expanded appear as a club. Tarsi five-jointed.

Series 2. Adephaga.-Antennæ with their terminal joints never leaf-like. Well-developed mouth-parts. Six or more ventral abdominal segments visible. Tarsi five-jointed, with the fourth joint quite distinct.

SERIES 3. Polymorpha.-Antennæ with the terminal 


$$
y
$$



joints clubbed or, from the third joint, saw-like, on the inner face. Other characters very variable.

Series 4. Heteromera.-Hind tarsi four-jointed, other tarsi five-jointed.

Series 5. Phytophaga.-Fifth tarsal joint usually so small that the members of this series appear to have four-jointed tarsi. Lower surface of the feet may be pubescent, bristly, or naked.

Series 6. Rhynchophora.-Head prolonged into a beak. Tarsi five-jointed, but, owing to the small size of the fifth joint, apparently four-jointed.

By some authorities the series Polymorpha is not recognized, and, instead, there is a series Clavicornia, with clubbed antennæ, and a series Serricornia, with serrate antennæ.

In the six series of the Coleoptera there are recognized more than eighty families. To deal with such an unwieldy horde in these pages is an impossibility. We have elected to survey sixty of the families, either because they are well represented in Britain or because they contain remarkable exotic species.

\section{Series 1. Lamellicornia.}

It is a remarkable fact that, so far as is known, the larvæ of all the seven families comprising this series are very similar in habit. They are all six-legged creatures with their bodies curved into the shape of the letter $\mathrm{C}$, and swollen at the hinder end. They live underground or in rotten wood, feeding upon their surroundings, or upon living roots, or upon excrement.

PASSALID 1 .-Large dark brown or black Beetles, with parallel-sided elytra, for the most part deeply furrowed. 
These Beetles are mainly tropical and all live in decayed wood; none are British. They are only mentioned here because of the remarkable fact that, though the adults are incapable of producing a sound, the hind pair of legs in the larvæ are in the form of modified hands, the fingers of which scrape on an adjacent filelike surface and produce a distinctly audible note. Exactly why the larvæ should possess these soundproducing organs it is hard to say.

LUCANID E.-Mandibles of the males highly developed and often of enormous size. Ten-jointed antennæ, usually elbowed and terminated by a comb-like club. The elytra entirely cover the upper surface of the abdomen.

The Stag Beetles are noteworthy on account of the remarkable development of the mandibles in the males; in some species the mandibles equal the body of the insect in length. It has been stated that this mandibular growth is of little or no use to the insects; be that as it may, a couple of male Stag Beetles, when in the mood, will use every effort to damage one another with these weapons, and their manœuvres on such occasions are highly entertaining.

There are three common species of Stag Beetle in Britain: the Small Stag Beetle, Dorcus parallelopipedus, a dull black insect without the excessive mandibular development of the Stag Beetle Lucanus cervus. Its larvæ live in decaying elm and beech, whilst those of the Stag Beetle are partial to decaying oak. The larvæ of the latter Beetle-our largest British insect, by the way-are very similar to those of the common Cockchafer. They do not become fully fed till the 


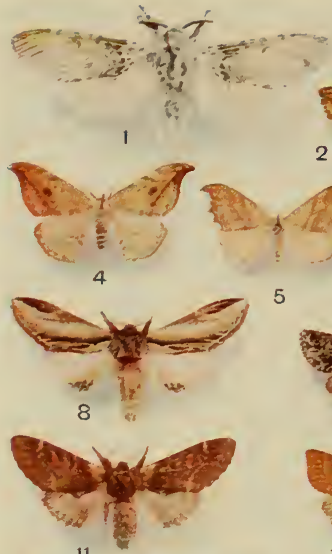

11

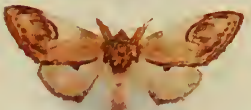

14

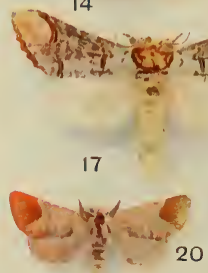

20
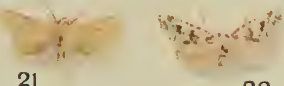

22

9. Acronycta rumicis

1. Dicranura vinula

3. Thyatira derasa

4. Drepana falcataria

5. Drepana lacertinaria

6. Asphalia flavicornis

7. Thyatira batis

8. Notodonta dictæa
5

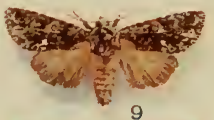

12

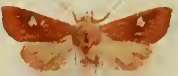

15

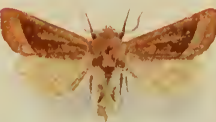

18

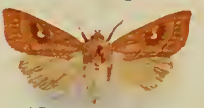

10. Jloma Oriun

11. Notudonta dromedarius

12. Leucania conigera

13. Acronycta psi

14. Notodonta ziczac

15. Hydræcia nictitans

16. Diloba cæruleocephala
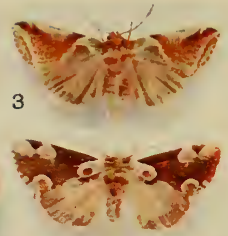

7
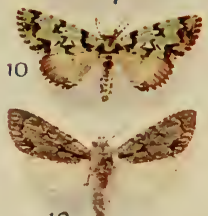

13

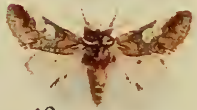

16

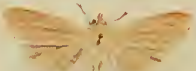

19

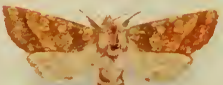

23

24

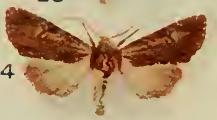
See page 153

17. Phalera bucephala

18. Hydræcia micacea

19. Lencania impura

21). Phalera curtula

21. Tapinostola fulva

22. Bryophila perla

23. Gortyna ochracea

24. Xylophasia rurea 
fourth year, and even then, after pupation, the adults often remain in hiding for some months. Like the larvæ of Passalida, those of the Stag Beetle are capable of producing sound. The smallest native Stag Beetle, Sinodendron cylindricum, should not be placed in the family according to some authorities; in place of the usual over-developed mandibles, the males of this species possess a single horn on the head.

CoPRID ж.--Terminal joints of the antennæ capable of wide separation and well coadapted. Pygidium usually exposed; six (usually) visible ventral abdominal segments. Abdominal segments placed in a line, and entirely covered by the elytra.

The Dung Beetles comprise an enormous family. Unfortunately, we do not possess in this country any of the Scarab Beetles, sacred to the ancient Egyptians and immortalized by Fabre. The French entomologist's description of the life and habits of the sacred Beetle, Scarabceus sacer, is so admirably conceived and so charmingly narrated that it should be read by everv insect lover.

In Britain the commonest Dung Beetles are the little Onthophagus fracticornis, a dull yellow Beetle, whose head and thorax are of a greenish metallic sheen; the small Dung Beetle, Aphodius fimetarius, with red elytra and a shining black thorax; the much larger, shining black Aphodius fossor; the black red-legged Aphodius rufipes; and Copris lunaris, a near relative of the Scarab. Of all the species in this family, the most familiar is the "Dor," "Dumble-door," or "Clock" Beetle, Geotrupes stercorarnus. This is one of the few Beetles that habitually takes to flight; its heavy, noisy efforts 
in aviation are a familiar sight on calm summer evenings; its defunct, mite-ridden carcass is by no means rarely observed. The closely related Geotrupes spiniger possesses an unpunctured ventral plate, which is absent from the "Dor" Beetle, whilst the equally common Geotrupes sylvaticus has much less deeply grooved and more metallic blue-coloured elyta.

Beetles of the genus Geotrupes can emit sounds by rubbing a rough surface on the hind-coxæ against a ridge on the under-surface of the abdomen, whilst those of the genus Trox do so by rubbing a pair of ridges, situate on the upper surface of the last abdominal segment but one, against a pair of somewhat similar structures which occur on the inner face of the elytra.

MELOLONTHID E.-Characters similar to those of the Copridoe, but the abdominal spiracles are not all in one line and the terminal spiracle is not usually covered by the elytra.

By far the most frequently encountered of the Cockchafers, not only in Britain, but on the Continent, is the so-called Common Cockchafer, Melolontha vulgaris. It is injurious both in the adult and larval stages, and in certain districts of France and Germany the adults appear, in some years, in such enormous numbers as to defoliate all the trees on a wide area. The chestnutcoloured Cockchafer is so distinct from all our other native Beetles that it may be identified by means of our illustration. The female deposits her eggs below the surface of the ground, and the larval life extends over from three to five years, according to the climate. During this period feeding takes place without interruption, except when hard frost drives the insects deep 


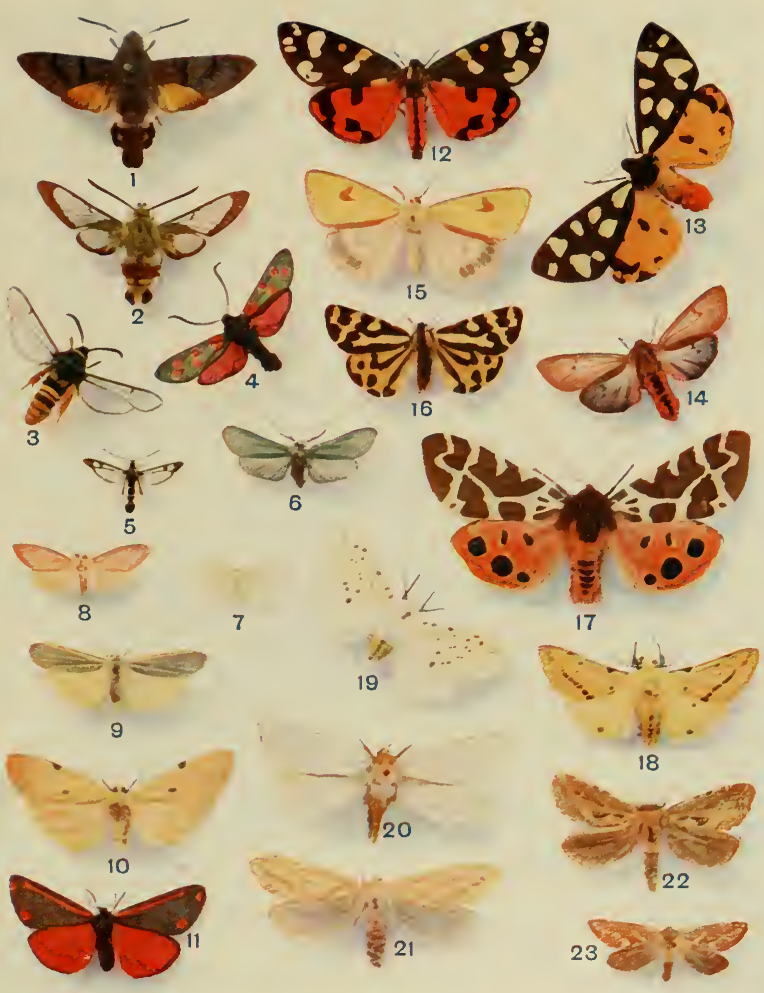

1. Macroglossa stellatarum

2. Macroglossa fuciformis

3. Trochiluum crabroniformis

4. Zygæna filipendula

5. Sesia tipuliformis

6 Ino globularia

7 Nudaria mundana

8. Calligenia miniata
9. Calligenia lurideoia

10. Gnophria quadra

11. Euchelia jacobææ

12 Callimorpha dominula

13. Aretia villica

14 Spilo-oma fuliginosa

15. Nemeophila russula

16. Nemeopliila plantaginis See paye 162
17. Arctia caia

1). Spilosoma Iubricipeda

19. Spilosoma menthastri

20) Hepialus humuli

21. Hepialus humuli female

22. Hepialus velleda

23. Hevialus hectus 

into the soil. Roots of herbage and trees form the staple food of the Cockchafer larvæ. Rhizotrogus solstitialis is more local, but equally common in some districts. Serica brunnea is a much more uncommon Beetle than its near relative, whilst our single representative of the genus Hoplia, H. philanthus, is rare in most localities.

RUTELID e.-As Melolonthida, but the abdominal spiracles are in two lines. Tarsal claws unequal.

Little is known concerning the life-histories of the Rutelidoe. The British June Bug, Phyllopertha horticola, is very similar in habit to the Common Cockchafer, and like that insect is an annoying garden and farm pest. Anomala frischii is rather less common. The members of this family are remarkable for their wide colour variations, and afford a striking lesson to the budding systematist that but little reliance can be placed on colour as a characteristic.

DyNASTID ж.-As Rutelido, but tarsal claws equal and front coxæ transverse and hardly prominent; head and thorax nearly always more or less horned, especially in the males.

This, the smallest, family of the Lamellicorns contains some of the largest individuals-in fact, there are no Beetles of greater bulk than some of the typical Dynastids. There are no British representatives of the family. The most remarkable feature of these Beetles is the curious and often unwieldy outgrowths which occur on their heads and prothoraces, especially those of the males. All the Dynastid larvæ feed upon wood, after the manner of Longicorn and Lucanid larvæ 
The Rhinoceros Beetle, Oryctes rhinoceros, is a formidable and striking-looking insect, black in colour and about two inches in length. From his head grows a long upwardly curved horn, and from the front of his thorax a double-pronged projection. The smaller brown South European O. nosecornis has very similar head adornments. The giant of the family is Dynastes hercules, a West Indian species with enormous head and thoracic appendages. The length of a well-grown male often exceeds six inches.

Cetonimse.-As Dynastido, but the front coxæ are more prominent and shorter transversely; head broad and flattened; ten-jointed antennæ with a compact three-jointed club.

The most beautiful Lamellicorns are to be found in this family. Even the Common British Rose Chafer, Cetonia aurata, rivals many tropical Beetles in the brilliance of its elytra. It is very destructive to roses. Gnorimus nobilis is a less common native species, and still less frequently met with is the black, white-spotted Oxythyrea stictica. The Rose Chafers are sun-lovers; in sunshine they readily take to flight by raising the tips of their elytra and so allowing the wings to be spread; they never separate their elytra in the usual manner. In the genus Trichius this peculiarity is not exhibited. These are pubescent Beetles, and one native species $T$.fasciatus, a black insect with orange markings on its elytra, frequents thistles.

One of the most beautiful Cetoniids, if comparison can be made among such resplendent insects, is the very common West African Cetonia marginata, a velvetyblack creature margined with orange. From the same 


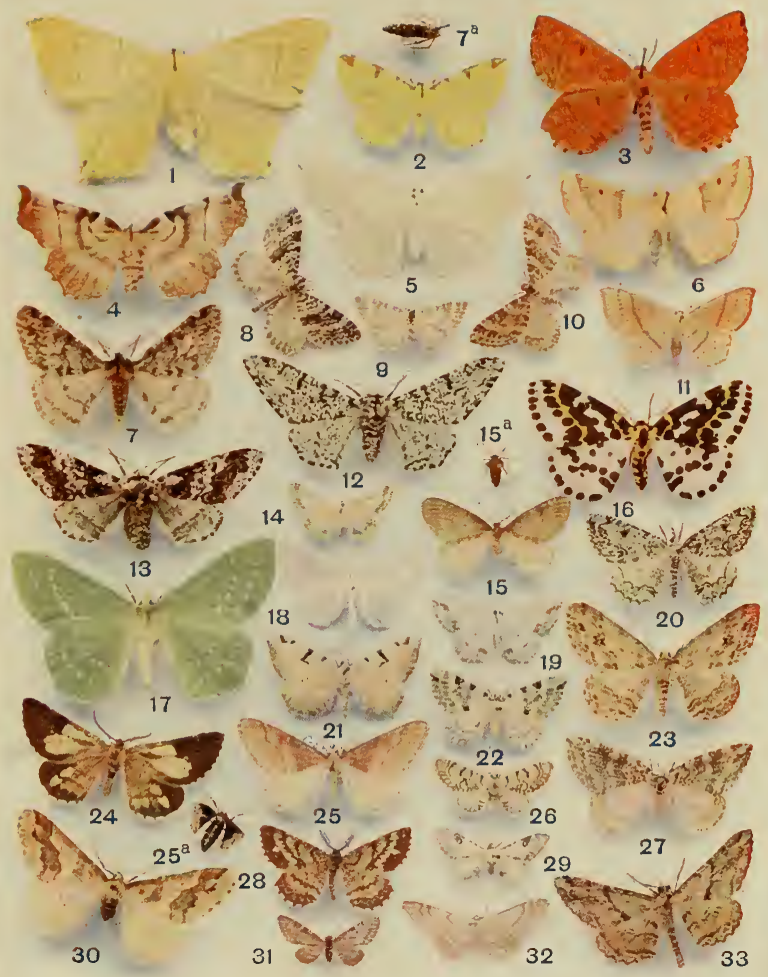

1. Uropteryx sambucaria

2. Rumia luteolata

3. Angerona prunaria

4 Pericallia bilunaria

5. Netrocampa margaritaria

6. Crocallıs elinguarıa

7. Phigalia pedaria

7a Phigalia pedaria (female)

8. Larentia cæsiata

9 Emmelesid albulata

10 Larentia didymata

11 Zanosoma punctaria

12. Amphidasys betularia
13. Amphidasys strataria

14. Acidalia bisetata

15. Cheimatobia brumata

15a. Cheimatobia brumata (female)

16. Abraxas grossulariata

17. Geometra papilionaria

18. Cabera pusaria

19. Acidalia ornata

21. Cleora lichenaria

21. Halia vawaria

22. Larentia viridaria

23. Tephrosia biundularia See paye 163.
24. Bupalus piniaria

25. Hybernia marginaria 25a. Hubernia marginaria female

26. Fupithecia venosata

27. Oparobia dilutata

2ฯ. Ematurga atomaria

29. Eupithecia oblongata

30. Hybernia defoliaria

31. Eupithecia satyrata

32 Acidalia aversata

33. Boarnia gemmaria 

country hail the Goliath Beetles, which often measure as much as four inches in length. Their heads are armed with horns.

\section{Series 2. Adephaga.}

The families comprising this series form a very natural group. The species are all carnivorous; on that account the series is sometimes known as Carnivora, a title which is obviously misleading.

CicINDELID $\approx$.-Eleven-jointed, filiform antennæ arising above the base of the mandibles; tarsi five-jointed; legs long and usually very slender; eyes prominent.

The Tiger Beetles are among the most active of the Coleoptera; some of them are powerful fliers, all are swift of foot. Bates, describing a South American species, said: "Their powers of running exceed anything I have ever observed in this style of insect locomotion; they run in a serpentine course over the smooth sand, and when closely pursued by the hand they are apt to turn suddenly back and thus baffle the most practised hand and eye." All the species are predaceous both in the larval and adult stages.

Most of the Tiger Beetles are resplendent in mail of metallic sheen, greens and blues predominating. Four species occur in Britain, and our green Tiger Beetle, Cicindela campestris can hold its own with its tropical relatives as far as colour is concerned. The Wood Tiger Beetle Cicindela sylvatica is of more sombre hue.

So far as is known, the larval habits of all the species in this family are similar. The female Beetles deposit their eggs in the ground. The larvæ, when they emerge, excavate deep vertical burrows and station themselves 
so that their hard, horny heads cover the mouth of their subterranean home. In this position they remain motionless till some passing insect comes within reach of their powerful jaws; then the victim is seized and devoured. All the known larvæ are well adapted for this mode of life. Their eyes are keen-sighted; their relatively enormous heads serve as excellent stoppers to their burrows; their slender, distorted bodies are armed with a pair of formidable hooks on the back of the fifth segment; by the aid of these hooks and the hind end of their bodies they can easily remain at the mouth of the burrow awaiting passing prey. Tiger Beetles are certainly useful in keeping down the numbers of harmful insects.

CARABID\&.-Antennæ filiform, terminal joints pubescent, arising from behind the base of the mandibles; tarsi five-jointed; legs long and slender.

The Ground Beetles form one of the largest families of Coleoptera, about thirteen thousand species having been described. They rival the Tiger Beetles in activity and voraciousness, though the majority of British species do not take to flight readily. Nearly all species are carnivorous both in the larval and adult stages; but, unlike the Tiger Beetles, the larvæ are active and fleet of foot.

Amongst the Ground Beetles with vegetarian tastes there are several species in Britain. Labrus gibbus is a grain-eater, and its larvæ devour roots. Amara fulva and $A$. aulica are common. Most species of the genus Harpalus are not wholly carnivorous, and $H$. ruficornis, $H$. ceneus, and $H$. latus may be met with in most gardens, probably ncar the strawberry-beds, for they are partial 
PLATE XLII 


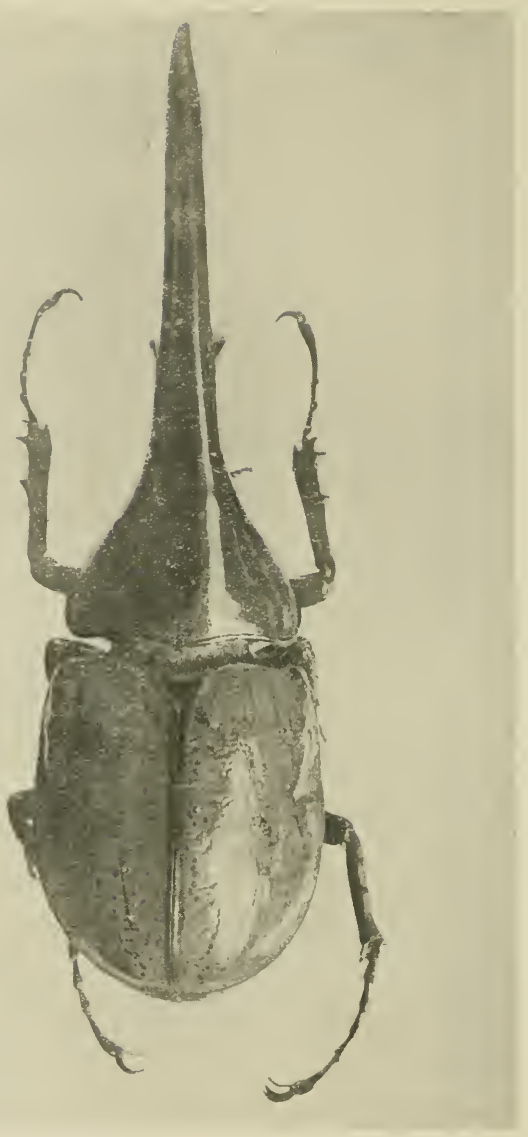

HERCULES BEETLE (DINASTES HERCULES), MAIE 
PLATE XLIV

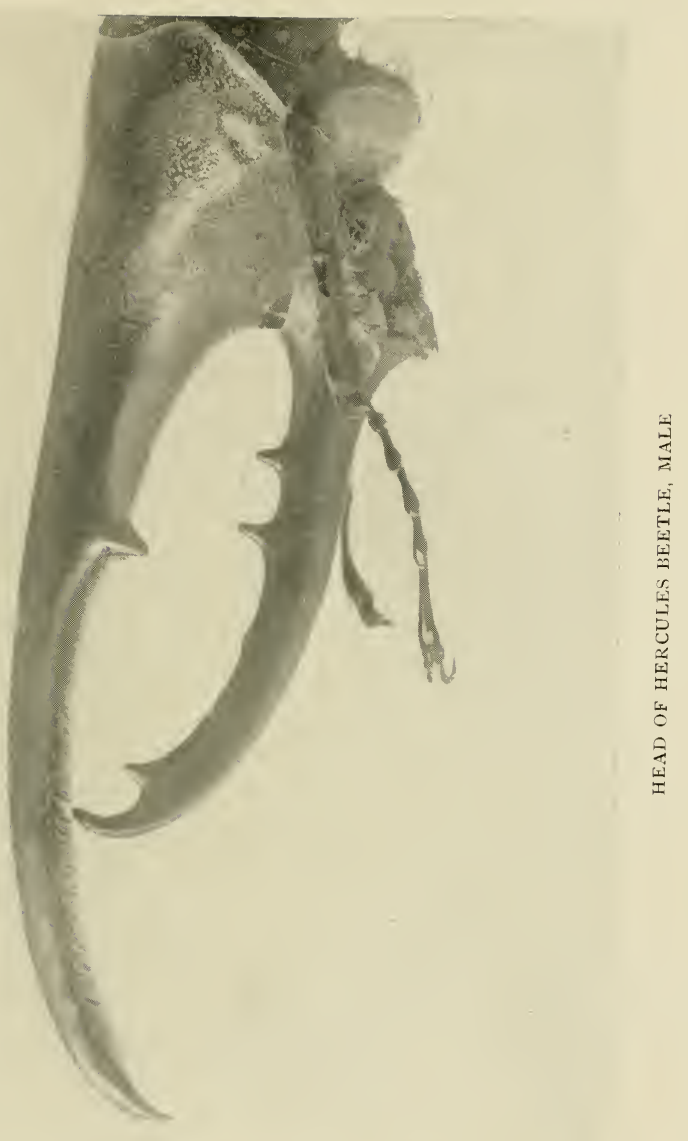


PLATE XLV

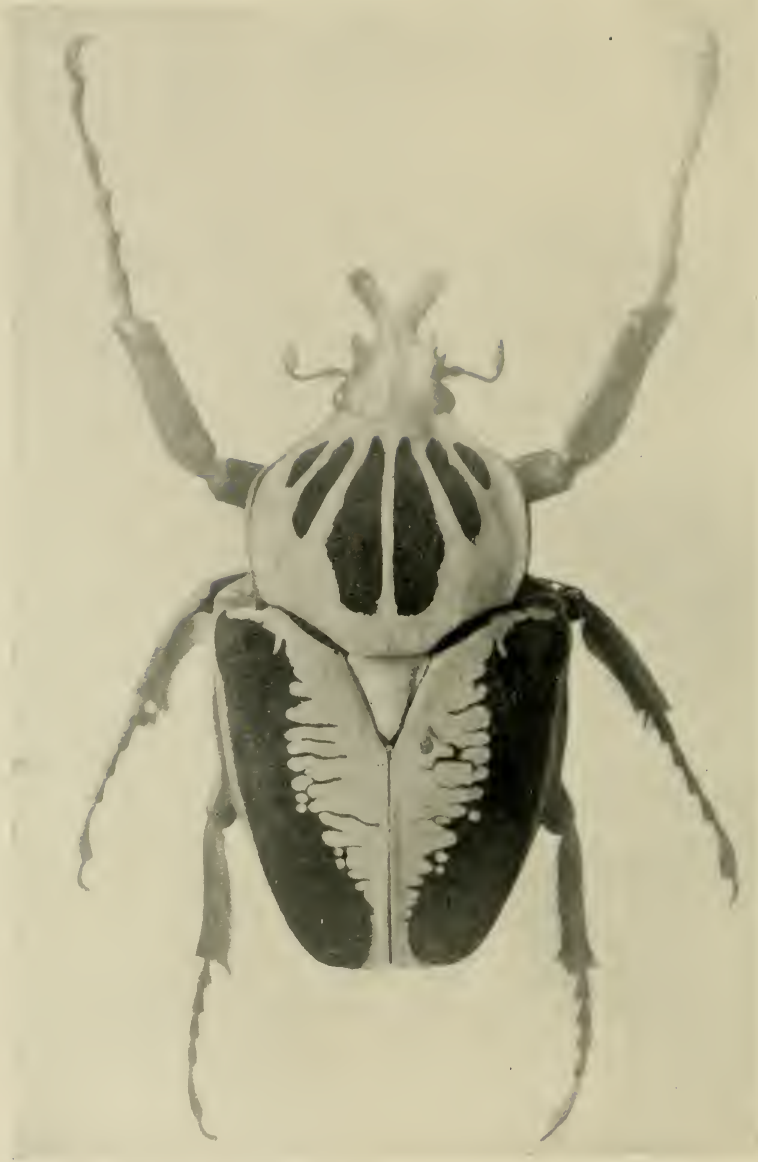

GOLIATH BEETLE (GOLIATHUS DRURIT), MALE 
1'IATE XLVI

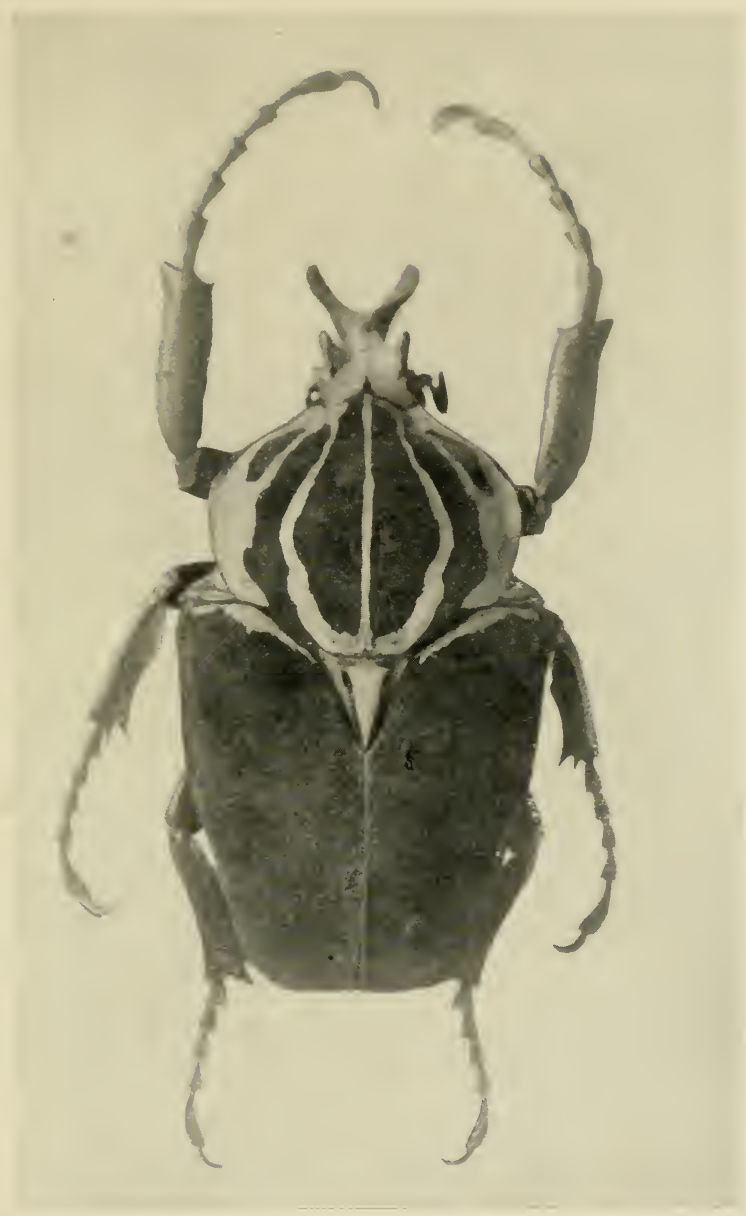

GOLIATH BEETLE (GULIATHUS GIGANTEUS), MALE 
PLATE XLVII

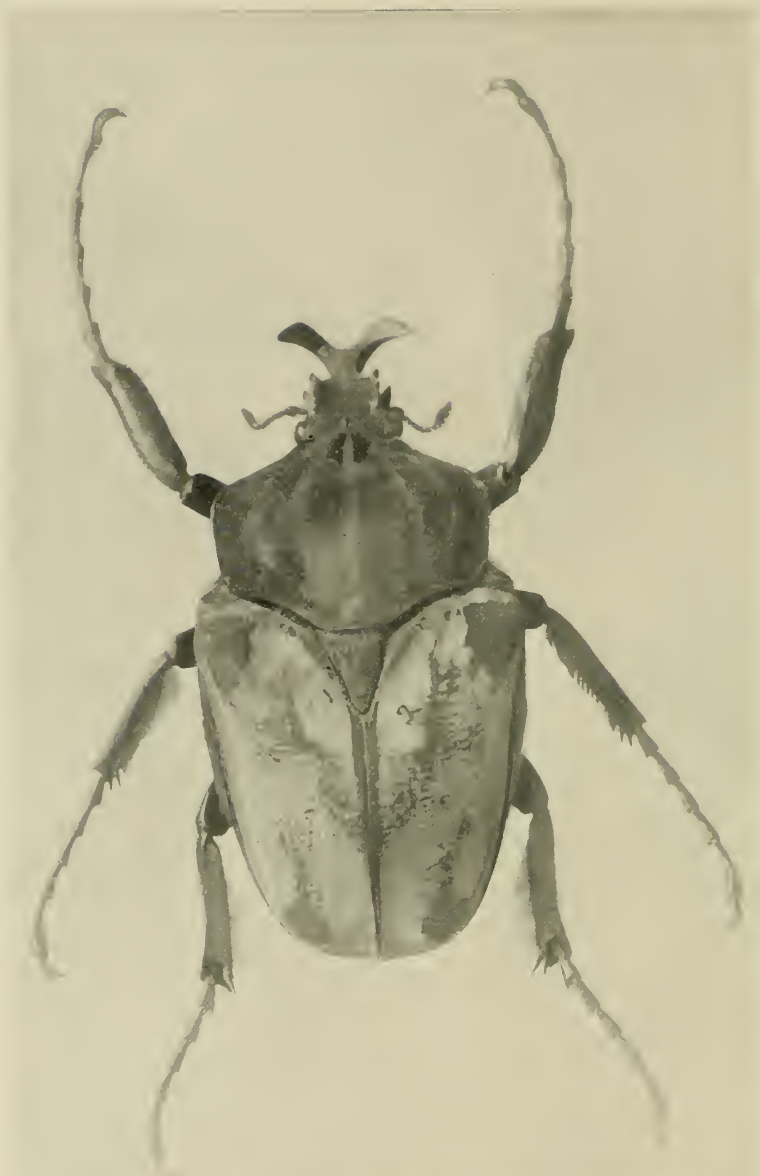

GOLIATH BEETLE GOLIATHUS CACICUS), MALE 


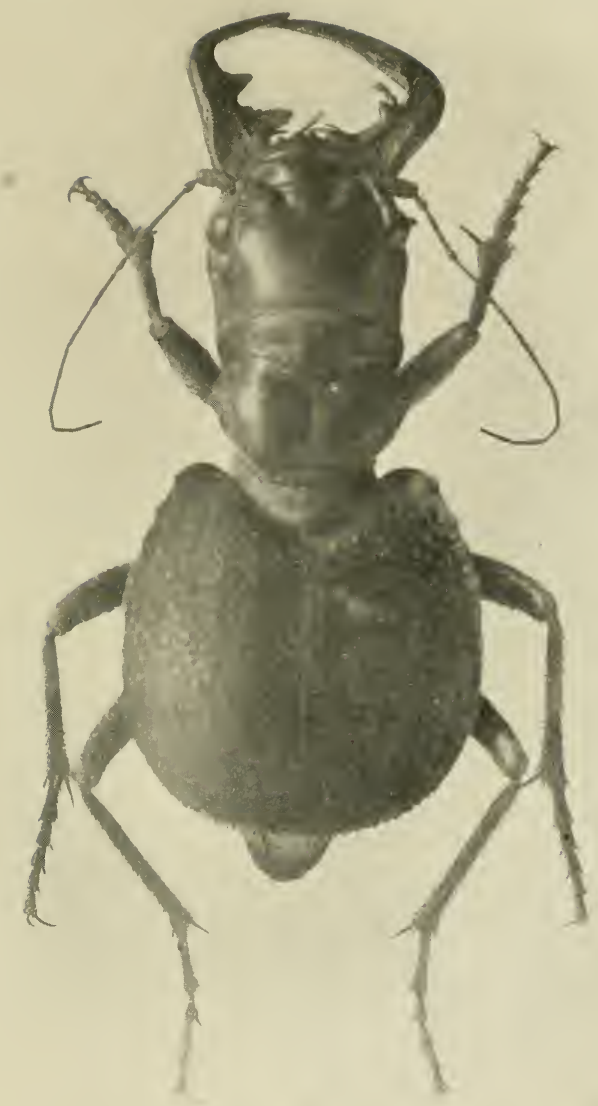


PLATE XLIX

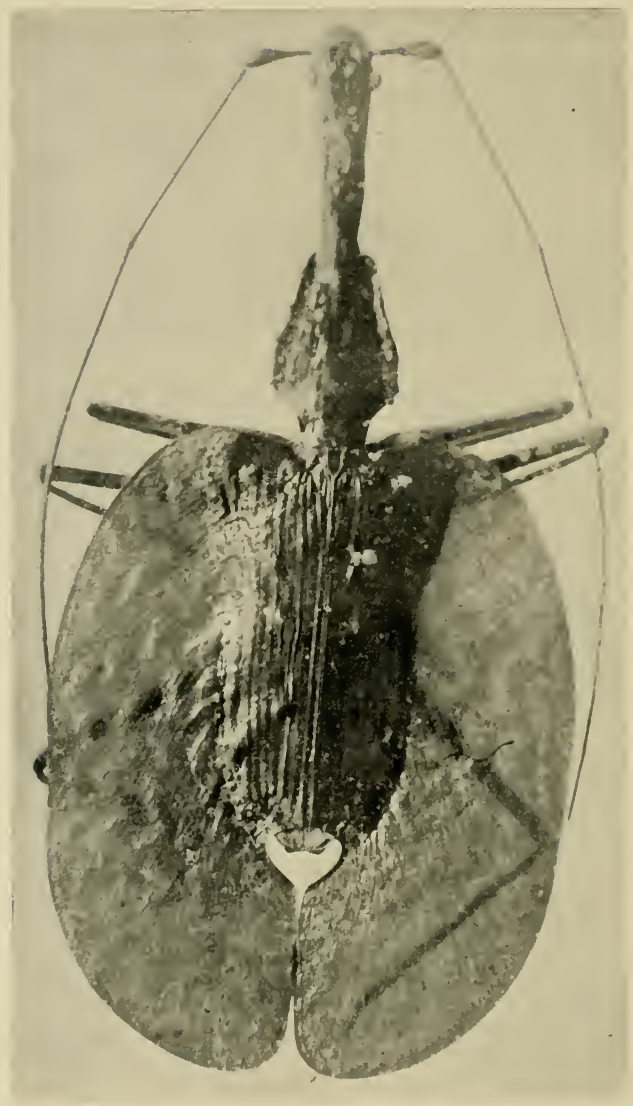

FIDDLE BEETLE (MORMOLICE PHYLLODES) 
to the ripe fruit, as also are many species of the genus Pterostichus, of which we figure $P$. cupreus, $P$. madidus, $P$. picimanus, and the wingless $P$. striola. A volume of considerable dimensions could be filled with descriptions of the wonderful forms and varied habits of Ground Beetles. The most curious members of the family are, perhaps, the British species of Aëpus, A. marinus and $A$. robinii, dwellers by the sea, which spend part, at least, of each day below water, yet they are not aquatic Beetles. The European and American cave-dwelling species of Anophthalmus are remarkable in that they are blind. One would imagine this a handicap to a free-roving predaceous Beetle, but so well are these insects furnished with tactile bristles that the loss of sight causes them little inconvenience. Maybe, like the Ants, they possess a sense of which we are not conscious. Other Carabids haunt the nests of Termites, and one species, Glyptus sculptilis, according to Horn, very closely mimics the queen of Termes bellicosus. One of the most beautiful Carabids is the golden-green Calosoma sycophanta. It is very rare in Britain, but common on the Continent. It haunts oaktrees and feeds upon the larvæ of the Processionary Moth. It was introduced into America to control the Gipsy Moth.

The most striking British species undoubtedly belong to the genus Carabus; the Violet Ground Beetle, Carabus violaceus, is a beautiful insect and one of our largest Beetles. Other species are the copper-coloured $C$. arvensis, the purple $C$. nemoralis, and the nearly black C. catenulatus.

A Ground Beetle which always claims attention is the 
curious little Bombardier Beetle, Brachinus crepitans With many Carabids it is a common habit to eject a caustic liquid as a protection against enemies. The Bombardier Beetle performs this feat so rapidly when alarmed, and the ejected fluid is so volatile, that a slight explosion ensues; hence the popular name of the Beetle. The ejection of an evil-smelling acid or alkaline fluid is a well-known protective device in the Animal Kingdom, from the notorious skunk downwards.

There is no more puzzling family for the entomological student than the Carabida. We have figured a large number of British species, but, however well executed, no figures will serve to identify the Ground Beetles. With accurate descriptions and even authentic named specimens before one, it is by no means easy to be sure of one's ground when attempting to identify some species of Ground Beetles.

Pelobidd ж.-Antennæ not pubescent; hind-legs slender, adapted for swimming; tarsi longer than tibiæ.

This small and unimportant family consists of but one genus and four species, of which one, Pelobius tardus, is British. Its chief claim to our notice lies in the peculiar adaptation of the larvæ to a purely aquatic life, and the remarkably loud note which the adults are able to sound.

DyTISCID .-Antennæ filiform and quite naked; legs adapted for swimming and useless for walking.

These true Water Beetles are beautifully adapted for an aquatic life. Their legs could not be more perfectly contrived for propulsion through the water; their method of breathing, while below water, is ingenious in the extreme, yet many authorities, including Sharp, 



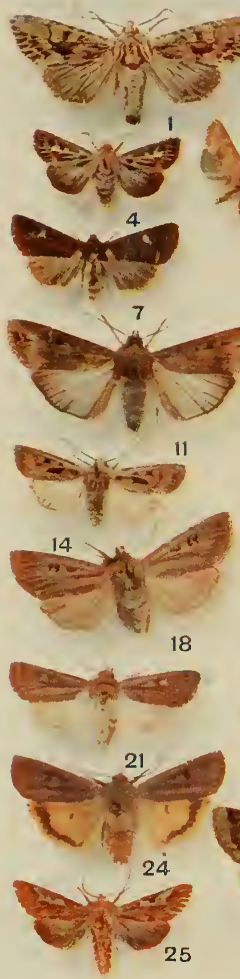

1 Xylophasia monoglypha 2 I) pterygıa scabriuscula

3. Neuronia popularis

4 Charæas graminis

5. Mamestra brassica

6 Apamea basilinea

7. Apamea didyma

8. Miana fascinuncula

9. Stilbıa anomala
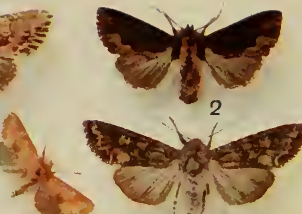

8

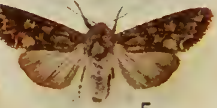

5
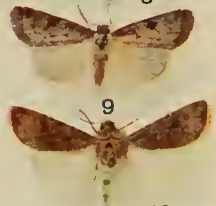

12

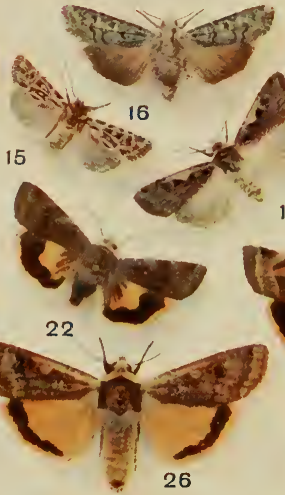

19
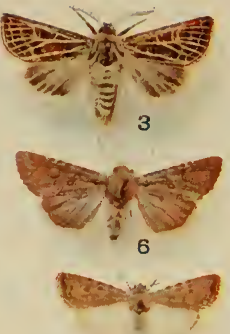

10

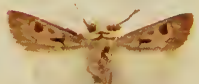

13
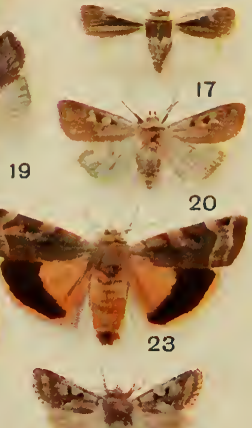

27
10 Caradrina quadripunctata

11. Agrotis suffusa

12 Agrotis segetum

13. Agrotis exclamationis

14. Agrotis tritici

15. Agrotis strigula

16. Agrotis pracox

17. Nectua plecta

18. Noctua augur See palve 165
19. Noctua C. nigrum

20. Noctua festiva

21. Noctua zanthographa

22. Triphæna ianthina

23. Triphana fimbria

21. Triphæna comes

25. Panolis piniperda

26. Triphana pronuba

27. Tæniocampa gothica 
consider them to be but modified terrestrial insects, for the reason that (1) in general, they are very similar to the Carabida in their organization, and they drown more quickly than the majority of land Beetles; (2) the adults can exist perfectly well on land, and are capable of taking long flights; (3) so far as is known, the pupæ are always terrestrial.

In some species the males and females differ from one another considerably; in Acilius sulcatus, for instance, the male has smooth elytra, whilst those of the female are deeply ridged. Of the hundred or so British species, the commonest are Agabus nebulosus and A. bipustulatus, Ilybius fuliginosus, I. ater, the interesting Dytiscus punctulatus and D. marginalis. The last named, the Margined Water Beetle, is well worthy of some study by every nature-lover. Its method of carrying a supply of air beneath its wellfitting elytra; the suckers on the fore-legs of the male by which he is enabled to hold the female during the breeding season; the oviposition of the female; and the curious, predaceous larvæ, somewhat reminiscent of those of the Dragon-flies, will supply material in abundance for the enlightenment of the field naturalist.

Other common pond frequenters of the family are Colymbetes fuscus, the sole British representative of the genus, and the minute, rust-red Hyphydrus ovatus.

\section{Series 3. Polymorpha.}

Paussid e.-Antennæ usually two but sometimes six or ten jointed and of extraordinary form; tarsi fivejointed; pygidium exposed.

These are amongst the most extraordinary of all 
Beetles. Much remains to be learned of their lifehistories, but, as far as our knowledge extends at present, all of them dwell in Ants' nests. As a family, they are easily recognized by their remarkable antennæ, which assume various bizarre forms. Some of them eject volatile liquids, after the manner of the Bombardier Beetle (p. 186).

The exact relations of the Paussidce to Ants are difficult to determine. "When observed in the nests they frequently appear as if asleep, and the Ants do not take much notice of them. On other occasions the Ants endeavour to drag them into the interior of the nest, as if desirous of retaining their company; the Paussus then makes no resistance to its hosts; if, however, it is touched even very slightly by an observer, it immediately bombards. The Ants, as may be imagined, do not approve of this, and run away." It is thought that the Ants derive some nutriment from the Beetle's secretions; it is certain that the latter devour the Ants' eggs and larvæ.

GYRINID\&.-Antennæ very short; eyes four; mid and hind legs adapted for swimming.

The Whirligig Beetles are as common in our ponds as are the Dytiscidae. Their evolutions on the surface of the water are always attractive, and they are the best adapted of all insects for their peculiar mode of life. There are many aquatic insects, a host of terrestrial ones, and but few that dwell normally on the surface of the water. Our common species is Gyrinus natator, sometimes called the "Shiner." When alarmed, its surface capers cease and it dives beneath the water, where it clings to some water-weed. Soon it rises again 


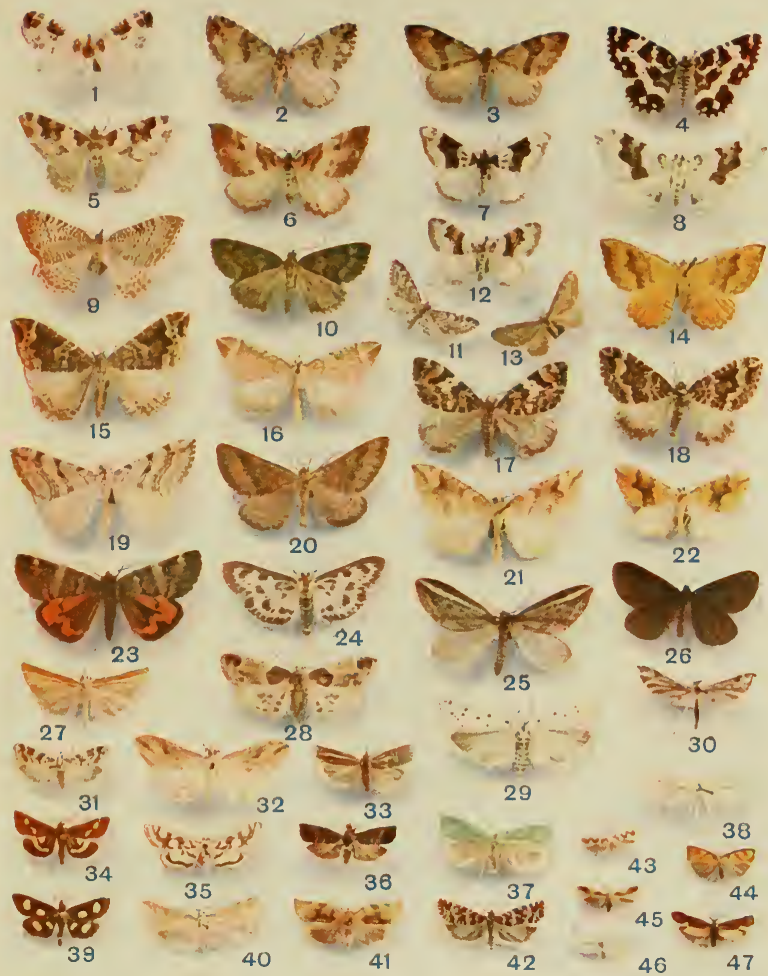

1 Melanthia bicolorata 2 Hypsipetes sordidata 3 Thera obeliseat 1

4 Melanippe hastata

5 Melanippe fluctuata

6 Anticlea badiata

7 Melanthia ocellata

8 Melanippe montanata

9 Eucosmia undulat

10 Cidaria siderata

11 Eupithecia nanata

12 Coremia designata
13 Eupithecia vulgata 14 Camptogramma bilineata 15 Cidarid prunata 16 Cidrtia testata 17 Cillaria immanata 18 Cidaria suffumata 19 Anaitis plaggiata 20 Eubolia limitata 21 Ciclaria populata 22 Cidaria fulvata 23 Brephns parthenias 24 Furrhypara urticata
25 Chesias spartiata 26 Tanagra atrata 27 Crambus tristellus 28 Pyralis farinalis 29 Iyelophila cribrum 30 Platyptilia gonodactyla 31 Scoparia dubitali 32 Pionea forficalis 33 Crambus pratellus 34 Pyrausta purpuralis 35 Hydrocampa stagnata 36 Carpocapsa pomonella

see page 168.

37 Tortrix viridana

38 Aciptilia galactodactyla 39 Ennychia octomaculata

40 Scopula lutealis

41 Tortrix ribeana

43 Mixodia Schulziana

43 Argyresthia brochella 44 Dictyoptery'

45 Gracillaria alcheniella

46 Ilachista argentella

47 Dasycera sulphurella 

to the surface, for the Whirligig Beetle cannot remain submerged for long; lack of air forces it to ascend.

The larvæ are purely aquatic, breathing by means of gills, which serve the double purpose of acting as breathing organs and as a means of locomotion. They are provided with formidable jaws, and are carnivorous.

There is one British species of the genus Orectochilus, but this is a less familiar creature than Gyrinus, for the reason that it only performs its aquatic evolutions at night. The giants of the family occur in the tropics, in Asia and Brazil.

HYDROPHILID E.-Antennæ short, consisting of one or two elongate joints at the base, two or more small intermediate joints, and a terminal part of broader, pubescent joints; tarsi five-jointed; abdomen with five visible segments.

This moderately large family of unattractive Beetles has been but little studied by entomologists. Some of the genera are aquatic, some are terrestrial. Of the ninety odd British species, by far the most interesting and the best known is the Silver Water Beetle, Hydro* philus piceus-with the exception of the Stag Beetle, the largest of the British Coleoptera. "This insect breathes in a most peculiar manner; the spiracles are placed near bands of delicate pubescence, forming tracts that extend the whole length of the body, and in this particular species cover most of the undersurface of the body; these velvety tracts retain a coating of air even when the insect is submerged and moves quickly through the water. (This gives the Beetle a silvery appearance, from which it has earned its popular name.) It would appear rather difficult to 
invent a mechanism to supply these tracts with fresh air without the insect leaving the water; but, nevertheless, such a mechanism is provided by the antennæ of the Beetle, the terminal joints of which form a pubescent scoop, made by some longer hairs into a funnel sufficiently large to convey a bubble of air. The insect therefore rises to the surface, and by means of the antennæ, which it exposes to the air, obtains a supply with which it surrounds a large part of its body; for, according to Miall, it carries a supply on its back, under the elytra, as well as on its ventral surface."

The female constructs a curious egg-cocoon, shaped like a chemist's retort. In this she deposits about fifty eggs, attaching them in rows to the side which will float uppermost. Then she sets the cocoon free to float on the water, with the portion which represents the neck of the retort projecting into the air. The larvæ are aquatic and feed upon animal food; from time to time they are compelled to rise to the surface for purposes of respiration.

Platypsyllide.-Curious parasitic Beetles of which little is known. They live amongst the fur of European and American beavers.

LEPTINID A.-Another very small and little understood family of parasitic Beetles. The British Leptinus testaceus occurs in the nests of mice and of Bumble Bees. The mice probably carry the Beetles from one Bee's nest to another.

SiLPHID\&.-Antennæ usually eleven-jointed (sometimes with nine or ten joints); elytra may or may not cover the body; usually five abdominal segments visible tarsi usually five-jointed, sometimes four-jointed. 

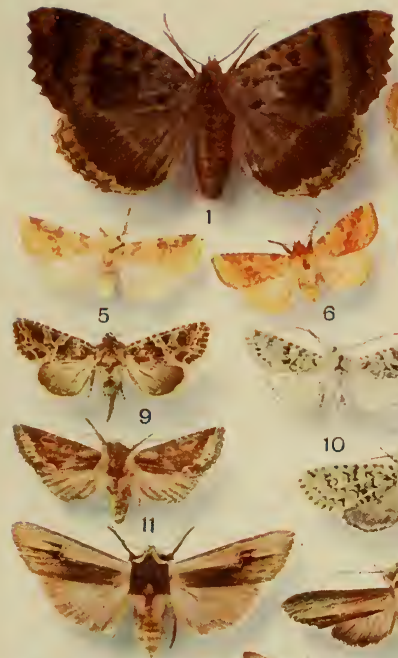

6

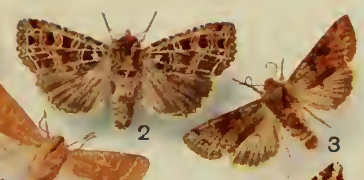

4 ?
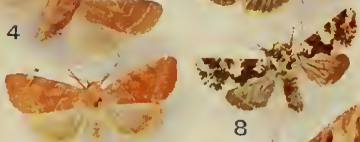

15
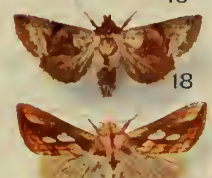

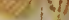
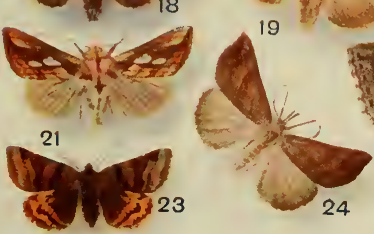

22
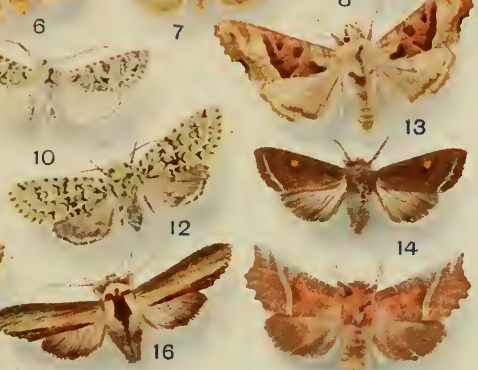

(1)
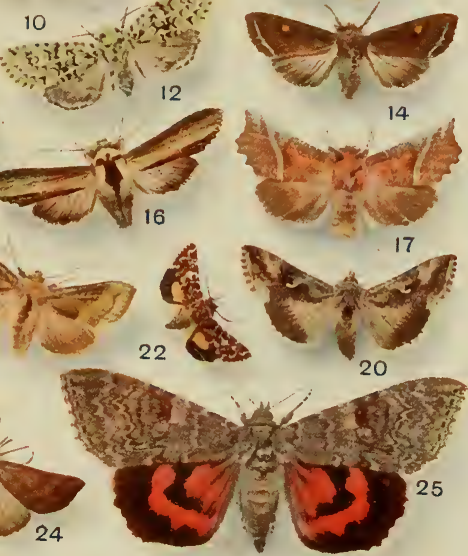

1. Nanıa maura

2. Mania typica

3. Tæniocampa incerta

4. Teniocampa stabilis

5. Zanthia fulvago

6. Zanthia flawago

7. Calymnıa trapezina

8. Dianthacia nana
9. Dianthæcia capsincola

10. Polia chi

11. Miselia oxyacanthæ

12. Agriopis aprilina

13. Phlogophora meticulosa

14. Hadena oleracca

15. Calocampa vetusta

16. Cucullia verbasci

17. Gonoptera libatrix

see page 165
18. Habrostola tripartita

19. Plusia chrysitis

20. J'nsia gamma

21. Plusia testucie

22. Anarta myrtilli

23. Euclidia gly phica

24. Hypena proboscidalis

25. Catocala nupta 

This family contains the "Burying" or Sexton Beetles (Necrophorus) and the Roving Carrion Beetles (Silpha); about a hundred species are known in Britain.

Of the Burying Beetles the best known are Necrophorus ruspator, $N$. vespillo, $N$. mortuorum, and, commonest of all, N. humator, the Black Burying Beetle. All of them, as a glance at the figures will show, are brightly clad, except for the funereal-looking humator. They live upon carrion, and a dead bird or mouse attracts them from afar, just as larger carrion attracts vultures. Having found their prize, they assiduously remove the earth from below it, so that in an incredibly short time the carcass falls into the Beetle-made grave. Once buried, the carcass forms the home of the Beetle eggs, and, later, home and food for the larvæ.

Necrodes littoralis is another native member of the family. Silpha atrata and S. lavigata are sworn enemies of Snails, though not averse to carrion when other food is lacking. S. thoracica seems partial to dead nestlings, and is frequently found in birds' nests. S. sinuata and, commonest of all British species, S. rugosa feed on carrion. The four-spotted Carrion Beetle, S. quadripunctata, is badly named, for instead of carrion it feeds upon insect larvæ. Most curious of all, however, is S. opaca, which so far forgets its obligations as a Roving Carrion Beetle as to feed entirely upon beet and similar crops, to which it is a very serious pest.

The family contains several foreign species which dwell in Ants' nests, and some cave-dwelling species which are blind, but little is known of their lifehistories.

Pselaphide.-Minute Beetles with short elytra; 
segments of the abdomen scarcely mobile; tarsi three jointed.

Claviger testaceus appears to be a welcome visitor to Ants' nests. It is fed by the owners as they feed their own larvæ, and transported by them from place to place.

StAPHYLINIDA.-Easily recognized by their short elytra and their elongated, exposed and mobile abdomens. Tarsi variable, sometimes five-jointed, sometimes only three, and not always the same on all feet.

The Rove Beetles are an enormous family, and in Britain alone there are more than eight hundred species. They vary greatly in size; some of them are exceedingly minute, and our "Devil's Coach Horse," Ocypus olens, ranks with the largest.

The most interesting point in the life-histories of certain species of Rove Beetles consists in their habit of living in the nests of other insects. Atmeles and Lomechusa are obviously on good terms with the Ants among which they dwell. Some species of Myrmedonia are looked upon as unwelcome guests by Ants; there are species, again, which dwell in Termites' nests, and one species, Velleius dilatatus, whose only residence is the nests of Wasps and Hornets. From the host of our British species we figure no less than nineteen; but the entomologist bent on identification should supplement the figures with descriptions, if he would not be led astray.

Histerid e.-Neat, jet-black, shining Beetles; antennæ short, bent, and clubbed; elytra hard and truncated, leaving two dorsal abdominal segments exposed; five ventral segments are visible. 



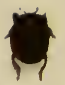

5

2

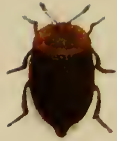

1

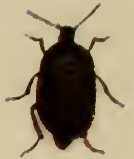

3

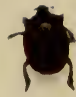

4
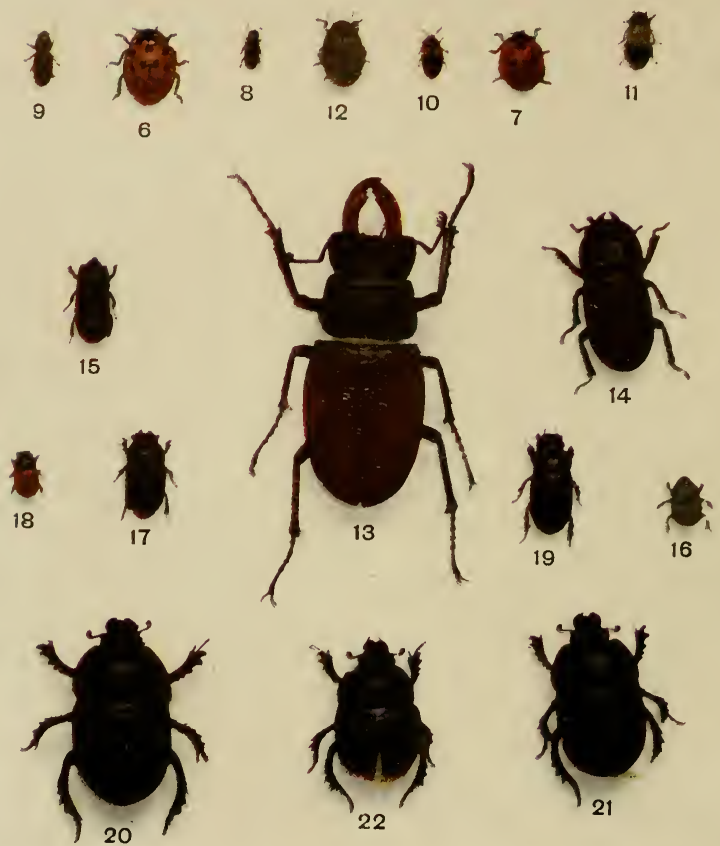

1. Silpha thoracica

Silpha rugosa

3. Silpha atrata

+ Hister unicolor

5. Hister cadaverinus

6 Anatis ocellata (Eyed Lady-bird)

7. Coccuella 7-punctata (7-spot Lady-bird)
8. Ips quadriguttata

9. Tenebrioides mauritanicus

10. Mycetophagus +-pustulatus

11. Dermestes lardarius (Bacon Beetle)

12. Byrrhus pilula (Pill Beetle

13. Lucallus cervus Stag Bretle

14. Dorcus paralielopipedus (Small Stag Beetle See mule 1 so

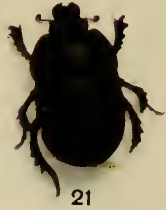

15 Sinodendron cylindricum 16. Onthophagus fracticornis 17. Aphodius fossor

18. Aphodius fimetarius

19 Aphodius rufipes

20. Geotrupes spiniger

21. Geotrupes stercorarius

22. Geotrupes sylvaticus 
The members of this family have been named Mimic Beetles, but the term is not a happy one, although derived from their scientific name-histrio meaning an actor or mimic. The origin of the name probably arises from their habit of feigning death, with heads retracted and all appendages drawn closely to their bodies.

Of the forty British species, we figure Hister unicolor and H. cadaverinus, both predaceous on the larvæ of Diptera and common in excrement. Another common species, $H$. bimaculatus, has a brilliant red spot near the tip of each elytron. Some of these Beetles, of the genus Hololepta, live under bark, and they have curious flattened forms, well adapted to their mode of life. There are species, too, which dwell in Ants' nests, and some which live with Termites.

NitmULID \&.-Small Beetles with eleven-jointed antennæ, the last three forming a club; tarsi fivejointed, the fourth joint being smaller than the rest; elytra may or may not cover the body.

These Beetles are of varied habit; nearly a hundred species are known in Britain; some live in flowers, some on carrion, and others on the sap of trees. Many of them have some resemblance to Rove Beetles, but they can be distinguished at once by the structure of their antennæ.

Meligethes ceneus, the Turnip Blossom Beetle, is common on the flowers of Crucifers, which it often damages to such an extent as to prevent the formation of seed. Pria dulcamerce lives in the flowers of Solanum dulcamera. Nitidula bipustulata, a small dull-black insect with a red spot on each elytron, is common on carrion. Ips quadriguttata is one of the sap-frequenting 
species, and in common with others of the genus is remarkable in possessing sound organs on the front of its head.

Trogositide.-Closely related to the Nitidulida, from which they differ by having tarsi of apparently four joints; in reality they are five-jointed, with the first joint very minute.

Of the three British species of this family, none are so well known as the imported Saw-Toothed Grain Beetle, Tenebrioides mauritanicus, which is now common everywhere. Whether it does more harm than good is a moot point; it certainly devours the larvæ of a number of grain-eating insects, but it also devours a considerable quantity of grain.

CRYPTOPHAGID A.-Minute Beetles with the terminal joints of the antennæ swollen; five-jointed tarsi; five ventral abdominal segments visible, of which the first is much longer than any of the others.

A small and little understood family, whose chief interest lies in the fact that the larvæ of some species dwell in Bees' nests, and that the adults, although good fliers, are transported thereto by attaching themselves to the Bees when they visit flowers. Other genera are dwellers in Wasps' nests.

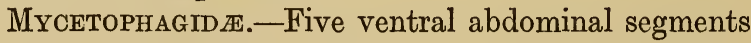
visible; tarsi four-jointed, except in the front legs of the male, when there are only three.

These Fungus Beetles are of little interest, except for the unusual anatomical character of the male described above. They mostly live either in fungi or below the bark of trees. There are about a dozen British species, of which Litargus bifasciatus and Mycetophagus quadripustulatus are amongst the commonest. 

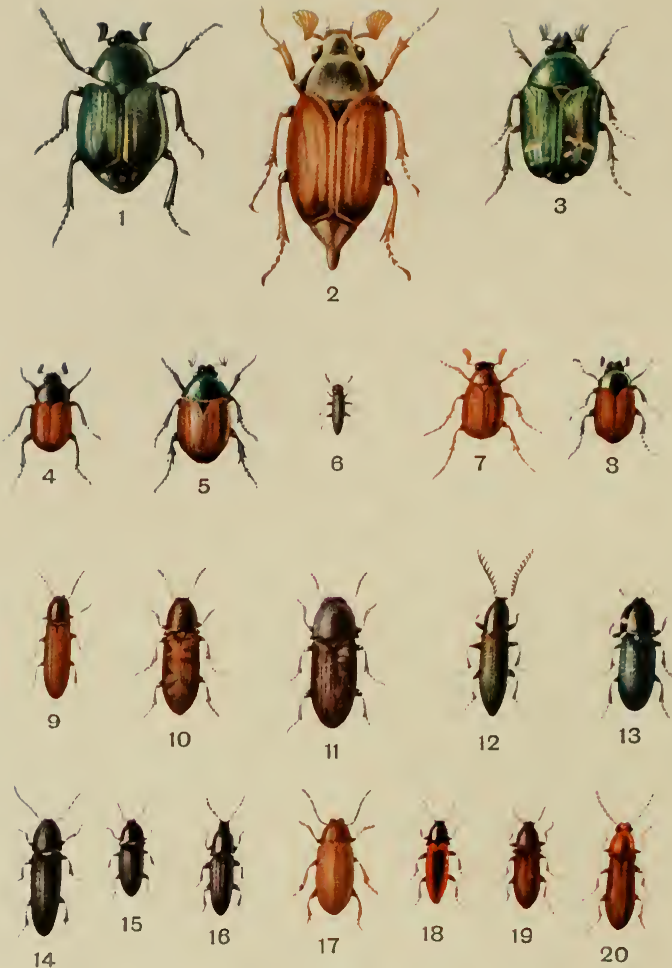

1. Gnurimus nobilis

2. Melolontla vulgaris

3. Cetonia aurata

Hoplia philanthus

Anomala frischii

Agrilus angustulus

Serica brunnea
Phyllopertha horticola

Athous lisemorrhoidalis

10. Corymbites tesselatus

11. Lacon murinus

12. Corymbites pectinicornis

13. Corymbites ieneus

1t. Melanotus rufipes
15. Agriotes obscurus

16. Athous niger

17. Dascillus cervinus

18. Elater sanguinolentus

19. Corymbites holosericeus

20. Campylus linearis 


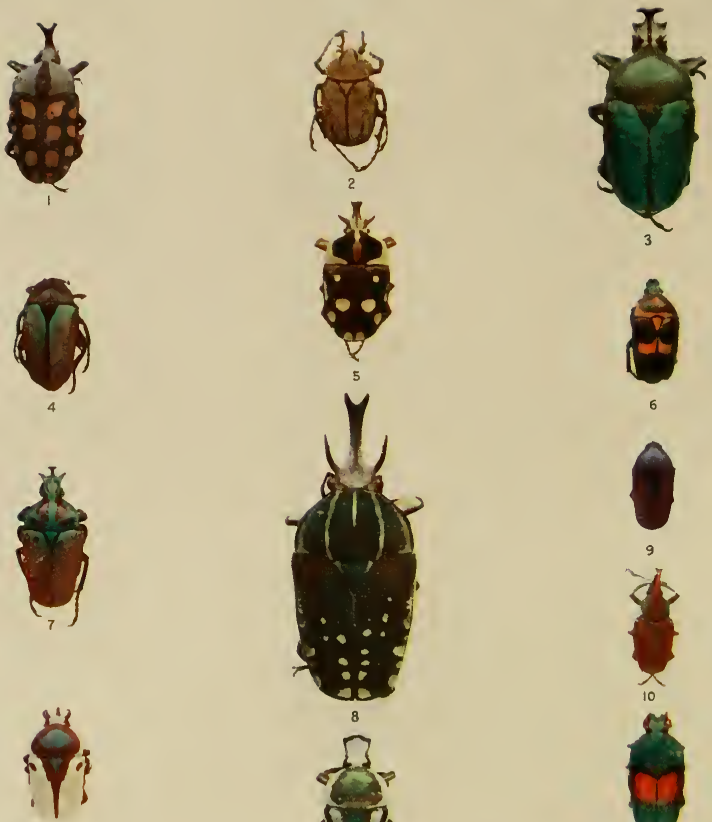

8
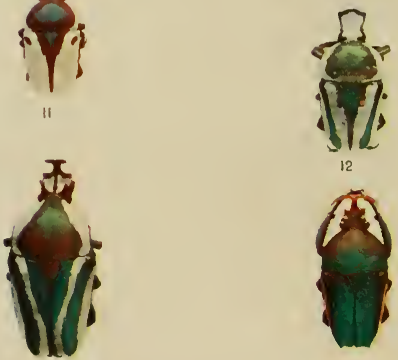

12

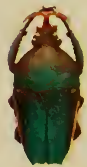

15

6

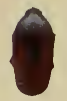

9
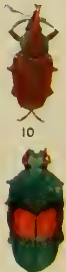

13

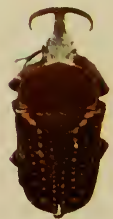

16

1. Amaurodes passerini

4 Ficcoptocnemis relucens

7. Neptunides polychrous

11. Ranжana hertoloni

11 Ceratorrhuna layardi
2. Dicranocephalus wallichi

5. Cheirolasia histrio

8. Colorrhina polyphemus

12. Ranzania petersiana

15. Eudicella gralli See paup 1s?.
3. Ceratorrhina oberthuri

6. Coryphocera dohrni

9. Smaragdesthes certzeni

10. Theodosia telifer

13. Lomaptera jamesi

16. Megalorrhina peregrina 
CocCINELLID A.-Antennæ eleven-jointed with illdeveloped clubs; head almost covered by the thorax; tarsi four-jointed, the third and fourth joints being very minute; nearly hemispherical in outline.

Ladybirds are familiar everywhere and to everyone. We have more than forty species in Britain, and the family is well represented the world over. In the main Ladybirds are useful insects, for most species are predaceous upon Aphides and other soft-bodied insects, both in the adult and in the larval states Ladybirds of the genus Epilachna are vegetarians, and are therefore harmful when they appear in numbers, as these Beetles are liable to do.

Amongst the commonest British species are the Seven-Spotted Ladybird, Coccinella 7-punctata; the Two-Spotted Ladybird, Coccinella bi-punctata ; the TenSpotted Ladybird, Coccinella 10-punctata, and the Thirteen-Spotted Ladybird, Hippodamia 13-punctata. There is always a difficulty in identifying these Beetles, by reason of the fact that the number of the spots on the specimen does not always correspond to the number one might expect to find. The reason is that the spots are very often fused, sometimes to such an extent that the insect is almost black. Anatis ocellata, which we figure, is a rare Ladybird in Britain.

The female Ladybirds, of the species named above at any rate, deposit their eggs upon the leaves of rosebushes and the like, which are attacked by Aphides. The larvæ, unlike those of the majority of Beetles, are very active and crawl about rapidly, devouring an enormous quantity of prey during their rambles. Pupation is quite unlike that of other Beetles, and more akin 
to the same phenomenon in Lepidoptera. The fully fed larva attaches itself to a support by its tail; its skin splits, and is pushed back to the tail end; the pupa remains suspended, after the manner of a Butterfly larva.

One Ladybird has been of real service to mankind, the little Australian, Novius cardinalis. Some years ago the orange and lemon groves of California were threatened with destruction by the Cottony Cushion Scale, Icerya purchasi. Means were taken to find out whence this noxious Scale originated, and it was traced to Australia. In its native country it was not a serious pest, for the reason that it was kept in check by a little red Ladybird. The Beetles were shipped to America and released amongst the Scale insects in the Californian orange groves, with the happiest results, and the Cottony Cushion Scale is no longer a serious pest in America. Large breeding establishments have been formed where the Beetles are raised in quantity, and whenever an outbreak of the Scale threatens, the insects are sent to the scene, in order that they may carry out their good work.

Dermestid ж.-Antennæ short, with well-developed clubs; tarsi five-jointed; five visible, movable, ventral abdominal segments.

These are moderate-sized or small sombre-hued Beetles, many of them pubescent or bearing bands or patches of hair. Owing to the fact that nearly all of them find their sustenance on hides, furs, museum specimens, skins, cheese, bacon, and the like, they are known as "Leather" or sometimes as "Bacon", Beetles. There are fourteen species in Britain, and the 
Bacon Beetle, Dermestes lardarius, is perhaps the commonest species. As our figure shows, there is a broad whitish or yellowish pubescent band across both elytra, and six black spots, three on each elytron, make the Beetle easy to identify. Attagenus pellio is destructive to furs; poor food for a Beetle, one would think, but some of these insects have been raised upon such uninteresting fare as horsehair, and all of them can survive for long periods without any food at all.

ByRRHIDж.-Round or oval Beetles; convex; tarsi five-jointed.

The Pill Beetles are of little interest, and hardly anything is known of their life-histories. They are slow-moving insects, and, when alarmed, they draw their legs close to their bodies, retracting their heads at the same time. This habit has earned them their popular name. Our common Pill Beetle, Byrrhus pilula, is figured.

BostRYCHID \&.--Tarsi five-jointed, the first being very small; five visible, ventral abdominal segments; sides of elytra parallel.

These Beetles are, with one exception, black or brown in colour, and their elytra are beautifully and characteristically sculptured. The ends of the elytra also are frequently peculiarly shaped, so that they have a curious truncated appearance. On these apical portions there are frequently spines.

In size the Bostrychids vary from the large Californian species, which attain a length of fully two inches, down to microscopic specimens. All of them are woodborers, and some are capable of doing a considerable 
amount of damage. For the most part, they are tropical or subtropical insects.

PTINID\&.-Tarsi five-jointed, the first joint often longer than the second; antennæ serrate; five visible, ventral abdominal segments.

These Beetles are almost all of them harmful, either because they devour food or because they damage wood.

The family is divided into two subfamilies, the Ptinida and the Anobiidas. Of the former the bestknown species is Ptinus fur, an inveterate enemy of museum specimens and all dried animal matter. The Anobiidae, as represented by Anobium paniceum, are little better. This common Beetle is very catholic in its tastes; opium, cinnamon, ginger, biscuits, and even cayenne pepper, do not come amiss. It is often called the Biscuit Weevil, though, needless to say, it is not a Weevil.

Anobium striatum, Xestobium domesticum, and $X$. tessellatum, are only too well known in many of our houses, and are the origin of so-called "worm-eaten" wood. The latter is the insect which has wrought so much havoc in the beams of Westminster Abbey.

The wood-boring Ptinids are known as "Death Watches," and are associated with much superstition. By beating their heads upon the walls of their tunnels, these insects are enabled to make a loud and intermittent ticking noise, which is said to presage death. As a matter of fact, the ticks are merely sex signals from one Beetle to another. The Beetle gives a definite number of taps, followed by a pause, and then repeats the performance. A captive "Death Watch" makes 

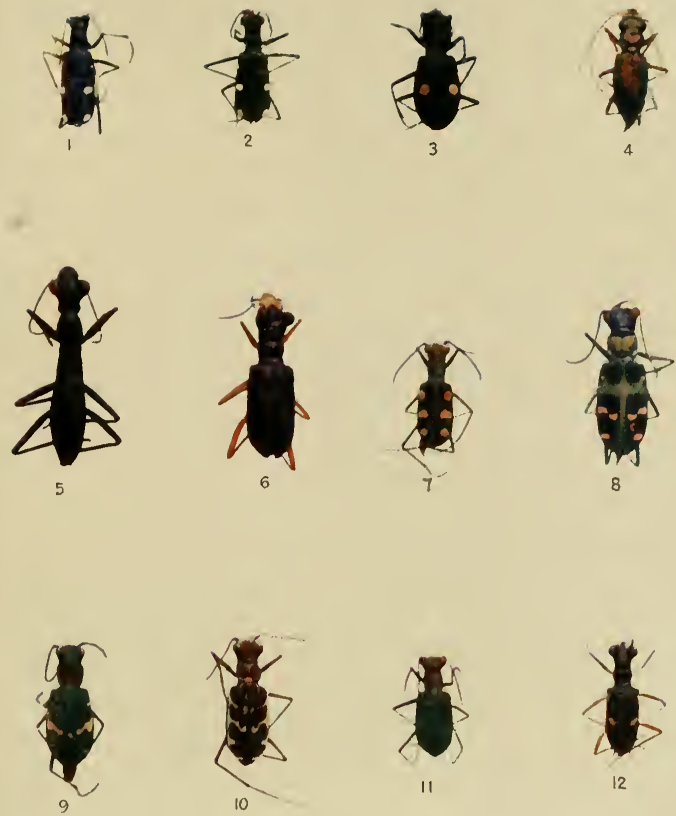

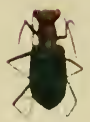

11

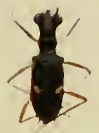

12
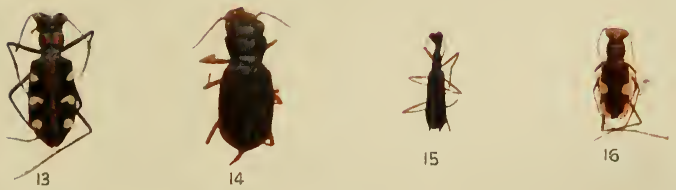

A GROUP OF TIGER BEETLES

1. Oxychila florida

5. Tricondyla aptéra

9. Cicindela sp.

13. Cicindela sp.
2. Oxychila gloriola

6. Therates labiatus

$\begin{array}{ll}\text { 10. Cicindela sp. } & \text { 11. Cicindela sp. } \\ \text { 14. Tetracha australasize } & \text { 15. Collyris sp. }\end{array}$ 7. Cicindela sp.

15. Collyris sp.
3. Pseudoxychila tarsalis 4. Tetracha carolina

15. Coll
8. Cicindela chinensis

19. Therates whiteheadi

16. Cicindela sp. 

an interesting specimen. By tapping with a pencil or other object outside the box in which the Beetle is confined the insect will answer the taps, but only when the same number of taps is given as is usual with the Beetle. For instance, some of these Beetles give five taps and a pause; a signal to the Beetle consisting of ten taps would not be answered; a five-tap signal would receive an immediate reply.

MALACODERMID A.-Tarsi five-jointed; always seven, and sometimes eight, visible, ventral abdominal segments; leathery elytra.

As the scientific name of this family indicates, these Beetles are covered with soft skins; the horny elytra of almost all the other families are wanting in the Malacodermidoe. The most interesting species of the family belong to the Lampyrides, for the reason that they are luminous. In some species the males are the more luminous, in other cases the reverse is the case. With our common Glow-Worm, Lampyris noctiluca, every stage from egg to adult is luminous, and the females are more so than the males.

Our figure shows clearly the striking difference between the sexes. The female is so unlike the commonly accepted notion of a Beetle that to her has been given the name of Worm. So far as is known, the adults do not feed; the larvæ are carnivorous, and feed upon living or dead Mollusca.

Other species of this family, belonging to the genus Telephorus, are very common upon wayside flowers in the summer-time. Frequently they appear in considerable numbers; the larvæ of all these species are carnivorous and feed upon Earth-Worms, Snails, Slugs, 
etc. Our common species are T. pellucidus, T. lividus, and $T$.rusticus, all of which we figure.

Species of the genus Lycus, which hail largely from Africa, are curious yellow and black insects with almost leaf-like elytra. Though the genus cannot be mistaken for any other, the species are frequently so much alike that they are very difficult to separate.

ClerID ex.-Tarsi five-jointed, joints two to four, furnished with membranous pads; antennæ arise from before the eyes; five or six visible, mobile, ventral abdominal segments.

These Beetles are nearly all conspicuously marked; all are predaceous, and their larvæ are exceedingly active.

Among the commoner British species are Necrobia rufipes and $N$. ruficollis; the former has been carried from one part of the world to another in hides, skins, etc., so that now it is practically cosmopolitan, whilst the larvæ of the latter have acquired the curious habit of pupating within the puparia of Diptera.

Thanasimus formicarius, a Clerid bearing more or less of a likeness to an Ant, as our figure shows, preys upon Beetle larvæ, mainly those with wood-boring tendencies. Clerids of the genus Trichodes are predaceous on Bee larvæ: T. apiarius on those of Honey Bees, and $T$. alvearius on those of Mason Bees. Other species are enemies of Locusts, and one of the most useful British members of the family is the beautiful metallic blue Corynetes cœruleus, an inveterate enemy of the woodboring "Death Watches."

DASCILLID «.-Eleven-jointed antennæ, rising from the front of the eyes; tarsi five-jointed; five visible, ventral abdominal segments; elytra somewhat delicate. 

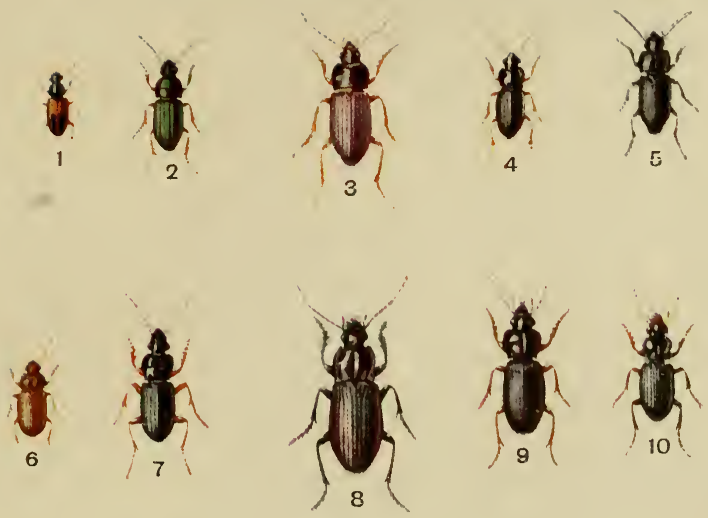
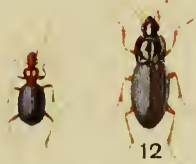

11
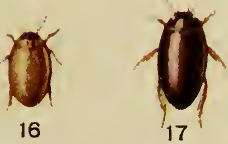
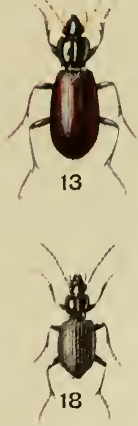
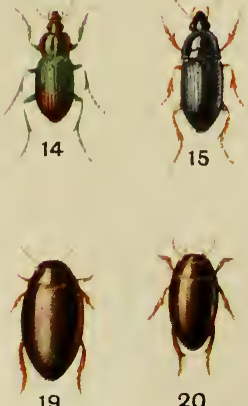

20
1. Dichirotrichus pubescens

2 Harpalus æneus

3. Harpalus ruficornis

4. Harpalus latus

5. Anisodactylus binotatus

6. Amara fulva

7. Pterostichus picimanus
8. Ptero-tichus striola

9. Pterostichus madidus

10. Amara aulica

1I. Brachinus crepitans

12. Calathus cisteloides

13. Pristonychus terricola

14. Pterostichus cupreus
15. Zabrus gibbus

16. Agrabus nebulosus

17. Ilybius fuliginosus

18. Anclomenus angusticollis

19. Ilybius ater

20. Agabus bipustulatus 

These little Beetles are not favourites with entomologists, and as a consequence but little is known of their habits and life-histories. Some of the larvæ are aquatic, some live on fungi, and those of our common species, Dascillus cervinus, live underground and feed on roots. Of another British species, Hydrocyphon deflexicollis, it is said that the adults live upon shrubs overhanging streams, and that, when alarmed, they dive below the water.

ELATERIDÆ.-Antennæ eleven-jointed, usually serrate on the inner margin, sometimes pectinate, and rarely filiform; tarsi five-jointed; the hind-angles of the thorax usually prolonged backwards; five visible, ventral abdominal segments.

The members of this family are commonly known as Click Beetles, on account of the very curious habit, possessed by most of them, of jumping into the air with a click. These jumping Beetles bend themselves backwards, so that the forward part of their heads and the hindermost part of their bodies alone touch the ground; then, suddenly straightening themselves, they spring upwards. The leaping powers of these Beetles vary with the species; the common British Lacon murinus does not jump.

Of our other native species we figure the Black and the Reddish Skipjacks, Athous niger and A. hoomorrhoidalis respectively; the black pubescent Melanotus rufipes; the beautiful, though rare, Elater sanguinolentus; and, most notorious of all, the Common Click Beetle, Agriotes obscurus, whose larvæ are known as "Wireworms." These larvæ are most injurious to the roots of growing crops. They are elongated, pale- 
yellow, six-legged creatures, and they spend all their time beneath the surface of the soil.

There is a remarkable genus of Elaters which hails from tropical America. All the species of the genus Pyrophorus so far described are luminous, but $P$. noctilucus is the best-known species. This insect, commonly known as the Firefly, bears a luminous patch on either side of the thorax, and another on the ventral surface of the abdomen. "The light given off
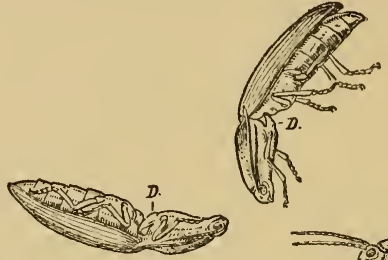

$$
7 .
$$$$
7 .
$$

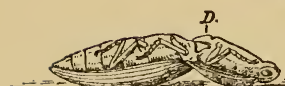

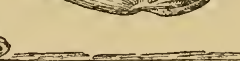

2.

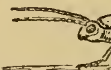

3.
4

Frg. 11.-An Elater (Skipjack).

At 1, lying on its back; at 2 and 3, in the act of skipping, and thereby, as shown in 4, landing upon its legs. $D$, Spine of the first thoracic segment (prothorax).

by these insects is extremely pleasing, and is used by the natives on nocturnal excursions and by the women for ornaments. ... The light is said to be the most economical, all the energy that is used being converted into light, without any waste by the function of heat or chemical rays."

BupREsTID jointed; tarsi five-jointed, the first five joints with membranous pads; abdomen with five visible, ventral segments; eyes oval. 


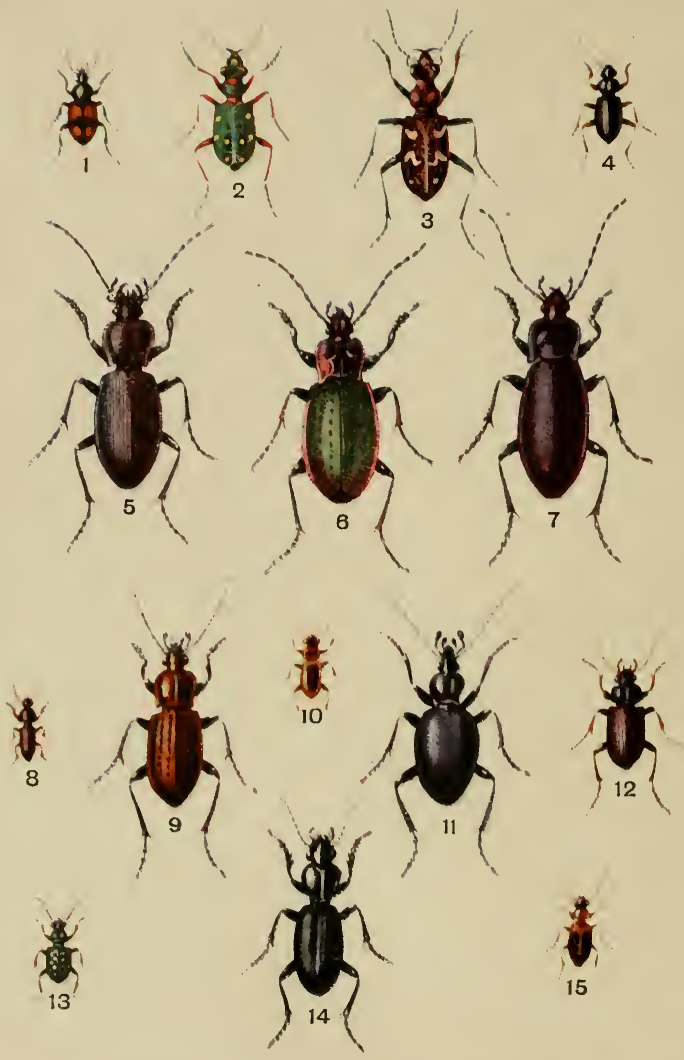

1 Panagæus 4-pustulatus

2. Cicindela campestris

3. Cicindela sylvatica

4. Leistus spinibarbis

5. Carabus catenulatus
6 Carabus neutoralis

7. Carabus violaceus

४. Clivinia fossor

9. Carabus arvensis

11. Notiophilus biguttatus See ynge 1sis.
11 Cjchrus rostratus

12. Nebria brevicolls

13. Elaphrus riparius

14 Broscus cephalotes

15. Badister bipustulatus 
These Beetles are remarkable for their brilliant colouring, metallic blues and greens predominating, though the species of the genus Capnodis are dull black.

Sternocera is a genus containing some remarkably ornate species, including $S$. castanea, with black head and thorax, the latter studded with red, and rich brown elytra.

The largest Buprestids are the Catoxanthas. C. bicolor is bright metallic green, with a red spot on each elytron; $C$. opulenta, a very similar insect, with white instead of red spots. Julodis contains the most curious species, all of them ornamented with brightly coloured hirsute tufts on their thoraces and elytra. J. cirrosa is black with yellow tufts of hair.

All of the ten British species are small and uncommon; Agrilus angustulus reflects little of the glory of his exotic relatives. In America the Red-Necked CaneBorer, Agrilus ruficollis, is a considerable pest of blackberries and raspberries, whilst Agrilus politus attacks oak-trees, killing off the smaller branches.

\section{Series 4. Heteromera.}

Tenebrionid ж.-Antennæ eleven-jointed as a rule; front coxæ short; tarsal claws smooth.

These Beetles are nearly all black in colour; they form an enormous family, one of the largest of the Coleoptera, but few species are native to Britain.

In form the Tenebrionidce are very variable; many of them are wingless, and most of them appear to feed upon vegetable matter.

One of our commonest native species is Tencbrio molitor, whose larvæ, known as "Mealworms," bear a 
striking resemblance to "Wireworms"--in fact, the similarity in general structure between the larvæ of this family and those of the Elateridoe is remarkable. "Mealworms" are of considerable economic importance. They are bred in millions as food for insectivorous birds, and sold to zoological gardens and private aviculturists. As with several more important commodities we in this country had relied altogether on foreign supplies, so that shortly after August, 1914, our stock ran out. Efforts were made to breed Mealworms in Britain, but we apparently did not know the secret of breeding the insects in large quantities, and the attempts were unsuccessful.

Frequently in our cellars we meet with a black, funereal-looking Beetle, whose form is well shown in our figure. This insect is the well-known Churchyard Beetle, Blaps mucronata. If we are lucky we shall come across its much rarer relative, the Cellar Beetle, B. mortisuga. Many of these insects are very fleet of foot, and may be found running rapidly over the ground in dry, sandy places. One of the commonest of our sand-loving Tenebrionids is Heliopathes gibbus, but the species of this habit reach their greatest pitch of development in Africa, Central America, and the Western States of North America. The genus Strongylium contains some brilliantly coloured species.

CisTELIDA.-Claws comb-like, other characters as Tenebrionidae.

This family is only mentioned because it is very closely allied to the last one, and by their claws alone is it possible to separate individuals of the two families. Their larvæ also are very similar. 
PLATE LIX
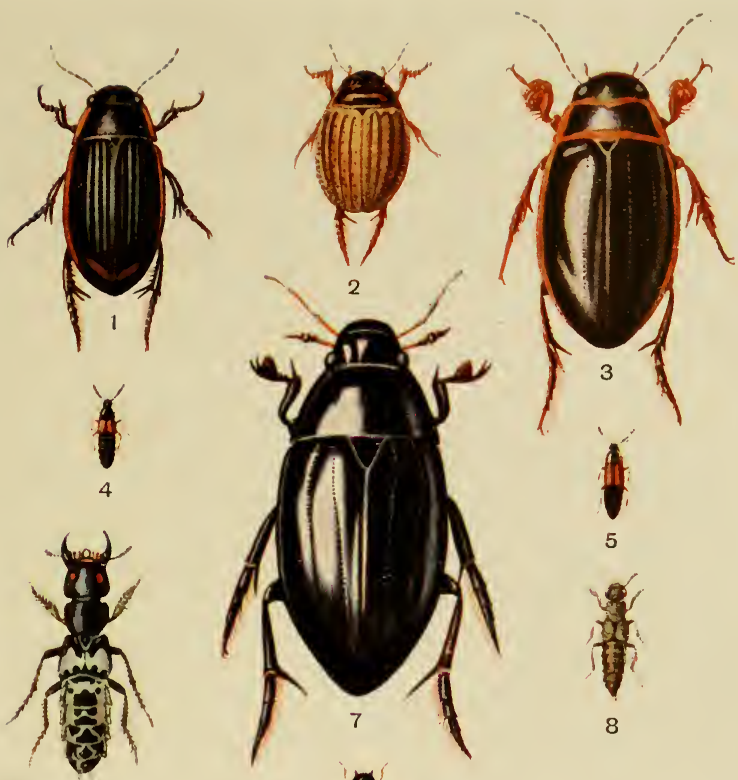

6
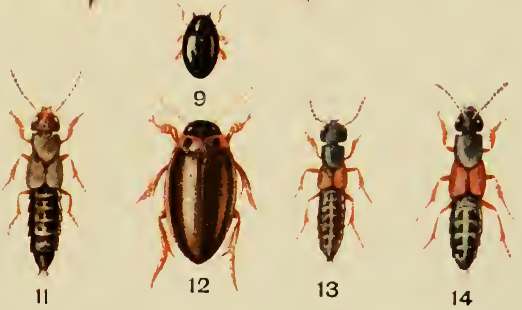

1. Dytiscus punctulatus (female

2. Acilins sulcatus female)

3. Dytiscus marginalis (male)

4. Aleochara fuscipes
5. Tachunus humeralis

6. Creophilus maxillosus

7. Hydrophilus piceus

8. Staphylinus pubescen.

9. Gyrinus natator See page 1st;.
10. Leistotrophus murinus

11. Leistotroplus nebulosus

12. Colymbetes fuscus

13. Staphylinus erythropterus

14. Staphylinus cæsareus 

MeloID\&.-Heads relatively broad, with abrupt necks; elytra short and soft; tarsal claws with closely applied appendages.

The family is divided into two subfamilies, the wingless Oil Beetles (Meloides), and the winged Blister Beetles (Cantharides). They are easily recognized by the characters given above, and they yield to no other family in point of interest, mainly on account of the extraordinary metamorphosis of many species. The early life of one of these parasitic Beetles is fully described elsewhere (p. 21). Some larvæ, however, notably those of the genus Epicauta, do not trust to such happy-go-lucky methods as are usual with the Oil Beetles, but hunt their hosts, and thus make sure of attaining their ends.

Many species of Blister Beetles are brilliantly coloured, yellows or reds and blacks predominating in the colour scheme; others are of metallic green or blue shades; yet others are black with neat white stripes. All of them are amply protected, though conspicuous, by reason of the fact that they emit a powerful vesicant when disturbed.

The common British Oil Beetles, Meloe proscaraboeus, and the Violet Oil Beetle, M. violaccus, are familiar objects in the spring. The females especially are easily recognized, with their much-distended bodies, heavily laden with eggs. Each mother Beetle lays approximately ten thousand eggs in a season. Immense as this figure may appear, it is by no means inordinate when the numerous risks which must be overcome before the adult stage is reached are taken into consideration. 


\section{Series 5. Phytophaga.}

The members of this series are easily recognized if it be borne in mind that " the tarsi have never the Heteromerous formula, the head is not constructed like that of Rhynchophora, nor the mouth and feet like those of Adephaga; the antennæ are different from those of the Lamellicorns." Practically all of them are vegetablefeeders; hence the name of the series.

BRUCHID s.-Prosternum very short, perpendicular in front; hind-femora more or less thickened.

All the members of this family are seed-eaters; accordingly, many of them are looked upon as pests by farmers. Another result of this seed-eating habit is that many species have become so distributed over the world as to be practically cosmopolitan. Bruchus chinensis is a case in point. Hailing originally from Eastern Asia, this chestnut-brown Beetle is now found the world over, and in quantities too.

The Pea Weevil, Bruchus pisi, deposits its eggs on pea-pods; the larvæ tunnel in the pods till they reach the ripening peas. In the seeds they take up their residence, one in each seed; there they complete their larval growth and pupate. Bruchus obtectus is a common bean pest which continues to breed amongst and feed on stored beans. Bruchus lentis, another pest of pulse, cannot complete its development in one seed, but requires two for the purpose. The largest members of this family belong to the South American genus Caryoborus. The family, though one of the most important economically, has been little studied by entomologists. But little reliable literature exists on 


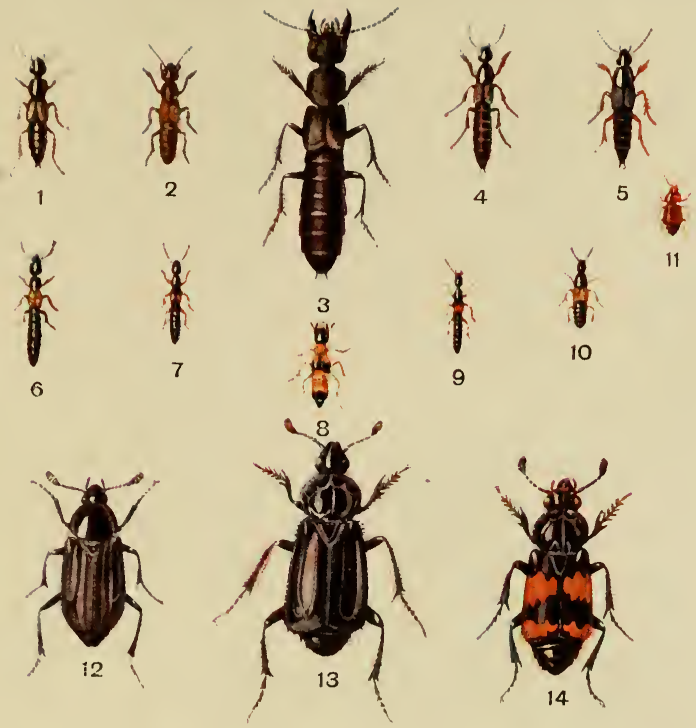

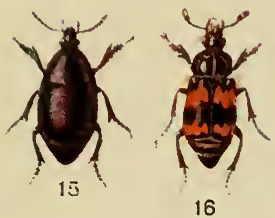

16

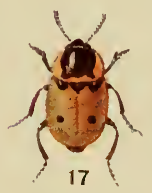

17

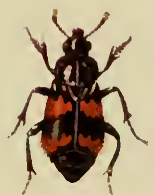

18

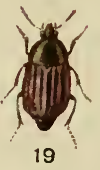

19
1. Philouthus æneus

2. Ocypus morio

3. Ocypus olens

4. Ocypus cupreus

5. Quedius lateralis

6. Xantholinus glabratus
7. 1.athrobium elongatum

8. Oxyporus rufus

9. 1.athrobium horeale

10. Quedius picipes

11. Olophrum piceum

12. Necrodes littoralis

13. Necrophorus humator See page 1!n1.
14. Necrophorus mortuorum

15. Silpha lavigator

16. Necrophorus vespillo

17. Silpha quadripunctata

18. Necrophorus ruspator

19. Silpha sinuata 

the Bruclidae, and their study is by no means easy. Owing to the fact that nearly all of these Beetles are clothed with a very transient pubescence, their identifcation, in the absence of well-marked characters, is rendered still more difficult.

DoNACID $2 .--A n t e n n \circledast$ slender; head narrowed behind the eyes; square thorax, much narrower than the elytra.

These Beetles are interesting on account of the fact that they are aquatic in the larval stage. None of them are common in Britain, but the most likely species to be met with are Donacia crassipes and D. semicuprea. Still more curious are the members of the genus Homonia, which are aquatic in all stages; $H$. curtisi is a very rare British species.

The extraordinary feature of Donacia larvæ is not that they dwell below the surface of the water, feeding upon the roots of aquatic plants, but that they derive the air necessary for their well-being from the plants on which they feed. The roots and stems of all aquatic plants are well provided with air-channels, a fact of which the larvæ are evidently well aware, for they puncture the plant tissues in order to tap the airsupply. When fully fed, they construct cocoons, which they affix to their food-plants. These cocoons are filled with air, for the larvæ before pupating take the precaution of cutting a channel in the supporting plant in such a manner that an air-channel and the interior of the watertight cocoon are in communication.

SAGRIDA.--An unimportant but highly ornamental family. These Beetles are dazzling in their splendour, competing even with the Buprestidae in the brilliance 
of their metallic colouring. The only species of any economic importance is Sagria splendida, which damages the stems of sweet potatoes. S. seraphica is a dazzling violet-blue West African species, and the Javan S. buqueti, the largest species of the family, is emeraldgreen with a red suture to its elytra.

CRIOCERIDA.-Closely allied to the two preceding species; mandibles bifid at the tip.

The larvæ of many species of this family are remarkable in that the anus is dorsal instead of ventral or terminal. As a result the voided excrement is forced on to the creature's back, where it is retained by a viscid substance, to act as a protection. This curious method of self-preservation may be well studied in the larvæ of Crioceris merdigera, a common pest of lilies.

The most notorious member of the family is the Asparagus Beetle, Crioceris asparagi. The adults are conspicuously marked red and black insects, with four whitish dots on the elytra, so arranged that they form a cross. The females lay curious black, barrel-shaped eggs, in rows, on the asparagus heads. These eggs, projecting at right angles to the surface of the stem, are all too familiar objects. The larvæ, which have not the habits of self-protection mentioned above, feed voraciously on the asparagus and ruin it for market purposes.

Clythrid ж.-Antennæ serrated; eyes large; thorax short and, at the base, as broad as the elytra. Broad, oblong, parallel-sided Beetles.

The species of this family are nearly all yellow and black in colour. There is only one British species, Clythra quadripunctata. 


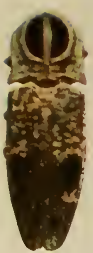

I
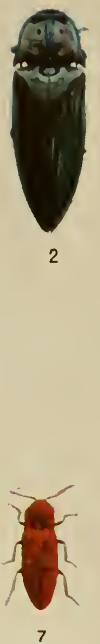

6

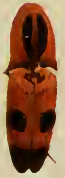

12

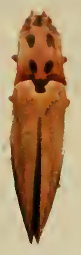

3

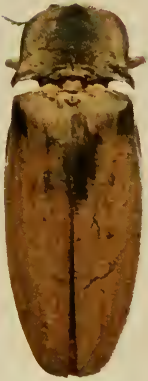

8

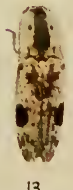

13
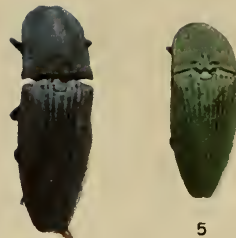

5

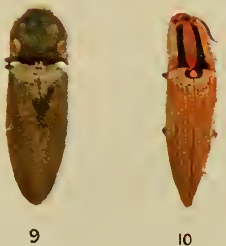

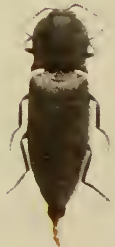

II
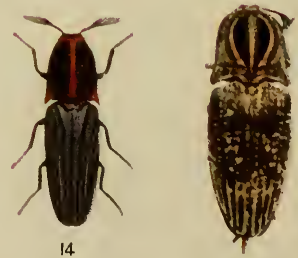

15

A GROUP OF CI.ICK BEFTI.ES

The plate is designed to show the remarkable variety of form and colour in the family. No. 9 is the so-called Fire-fly. 
The most remarkable fact about these Beetles is that the females, when depositing an egg, hold it with their hind-legs till they have covered it with an envelope of excrement. This envelope becomes leathery, and forms a case for the larva, in which it dwells, enlarging it from time to time, during the whole of its life.

Cryptocephalide.-Long thread-like antennæ; elytra usually covering the abdomen.

These are small Beetles which frequent flowers. Many of them are brilliantly coloured, and blacks, greens, blues, violets, reds, yellows, and metallic copper shades predominate. A by no means uncommon British species, Cryptocephalus sericeus, is yellowishgreen in colour.

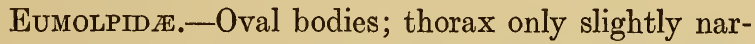
rower than the bases of the elytra; antennæ long, with terminal joints larger than those at the base.

Another family whose species are resplendent in brilliant metallic armour. There are few European species; one of them, however, Adoxus vitis, a black insect with reddish tibiæ and antennæ, is a serious vine pest. The South American Eumolpus fulgidus is a beautiful Beetle; its colours vary from brilliant metallic blue to green, and in some lights it reflects a warm copper-red hue.

ChrYsomelid ж.-Terminal joints of antennæ barely longer than the others; head separated from thorax; elytra convex, oval, and entirely covering the body.

The Chrysomelidce are a numerous family and contain some injurious species. They are often referred to as Leaf Beetles, and sometimes as Golden Apple Beetles. 
Of the British species we figure Chrysomela marginalis and $C$. staphylea. A more beautiful, but very rare, native Leaf Beetle is $C$. cerealis. It is brilliant goldengreen, with a purple lustre; its thorax and each elytron are decorated with three deep blue bands, and its suture is of the same colour. It is one of the most ornate of a gaudy family.

As an example of the varied hues of the Chrysomelas, Kirby says: " $C$. banksii is bronzy green; $C$. limbata is black with a red border; $C$. rufa is pale brownish-red. $C$. goettingensis is dark violet, and $C$. schach is blueblack." The tropical American genus Doryophora includes some beautiful species. D. punctatissima, a large species, has a black head and thorax, and its pale yellow elytra are studded with small black spots. The most sombre species belong to the genus Timarcha, of which we figure the curious Bloody-Nosed Beetle, T. tenebricosa, so named on account of its similarity to some of the Tenebrionids. It is the largest European Chrysomelid, sluggish and wingless, and when touched it emits a blood-red fluid; hence its popular name. The North African T. turbida is a very similar insect. By far the most notorious of all the family is the dreaded Colorado Beetle, Leptinotarsa decemlineata. Originally finding its nourishment on wild Solenacea in the Rocky Mountains, it later took to evil ways and became a very serious pest of potatoes. Though introduced into this country from time to time, it has always been eradicated before it could do serious damage.

HaLTrCIDA.-Long cylindrical antennæ irserted close together between the eyes; hind-legs longer than the others and with thickened femora. 



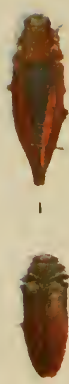

4

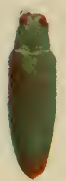

8

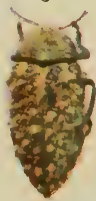

10

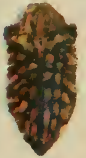

14
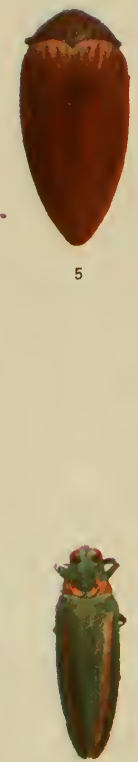

II

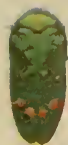

2
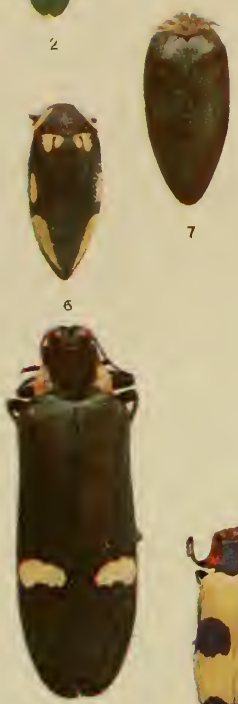

12

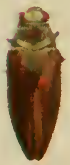

15

7
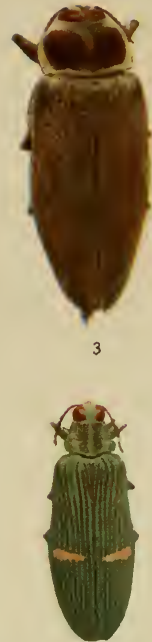

9

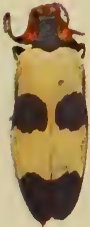

13

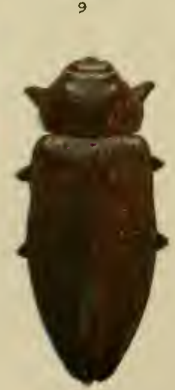

16
1. Cyphogastra javanica

2. Conognatha practiossissima

3. Euchroma goliath

4. Belionota sumptuosa

5. Sternocera eschscholzi
6 Sternocera orissa

7. Sternocera pulchra

* Chrysochroa fulminans

9 (atoxantha opulent:

11). Julodis sp.

11. Chrysochroa vittat
12. Catoxantha bicolor

13. Chrysocliroa buqueti

14. Juloc is cirros:

15. Philocteanus maitlandi

16. Buprestis gigantea See yaufe 20?. 
Minute Beetles, usually of bronzy blue or black colour. They are agile jumpers, and on that account are usually known as Flea Beetles, Turnip Fleas, or even as Turnip Flies. There is no need to labour the point that the term "Fly" is a misnomer. The species of the two common genera, Haltica and Phyllotreta, are nearly all injurious to Cruciferous plants.

GaLeructDa.-Antennæ long, slender, and cylindrical, inserted close together between the eyes; legs long and slender; femora never thickened; body long, usually somewhat depressed.

These Beetles often resemble the Criocerido in general form and colouring, but may easily be distinguished by their antennæ. We figure Galeruca tenaceti, a species frequently met with on tansy flowers. Many species are injurious, notably the EIm Leaf Beetle, Galerucella luteola.

HISPID $\approx$.-Antennæ inserted close together on the front part of the head, which latter organ is bent downwards.

This is a small family of tropical Beetles. The members of the genus Hispa are peculiar in that their elytra and thoraces are covered with long and sharp spines. The pupæ of many species are also spinous; the larvæ, so far as is known, live between the upper and lower epidermis of some favoured leaf till nearly fully fed; then they invariably forsake their temporary home and tunnel into the midrib of a second adjacent leaf to pupate.

CASSIDID e.-Agree in most characters with the Hispida, but the margins of thorax and elytra are so expanded that they have earned the name of " Shield" or "Tortoise" Beetles. 
Many Tortoise Beetles are beautifully coloured during life. Several, including the British species Cassida viridis and $C$. equestris, are green; others are black and orange or black and red, but most beautiful of all are certain iridescent species. Unfortunately, the colours in most cases fade soon after death; our figures are made from faded specimens.

The larvæ of these Beetles have the peculiar habit of covering themselves with excrement-not owing to their anatomical structure, as in the case of certain of the Crioceridce, but of set purpose, and by the aid of a forked appendage on the hinder portion of their bodies.

Sharp records a most extraordinary costume which is assumed by the larvæ of a South American Tortoise Beetle, of the genus Porphyraspis. " $P$. tristis is apparently a common insect at Bahia, where it lives on a cocoa-palm. The larva is short and broad, and completely covers itself with a very dense coat of fibres, each many times the length of the body and elaborately curved, so as to form a round nest under which the larva lives. On examination it is found that these long threads are all attached to the anal extremity of the insect, and there seems no alternative to believing that each thread is formed by small pieces of fibre that have passed through the alimentary canal, and are subsequently stuck together, end to end. The process of forming these long fibres, each one from scores of pieces of excrement, and giving them the appropriate curve is truly remarkable. The fibres nearest to the body of the larva are abruptly curled so as to fit exactly and make an even surface; but the outside fibres stand 

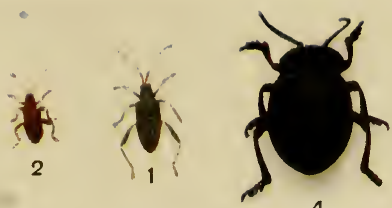

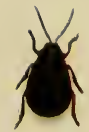

7

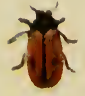

3

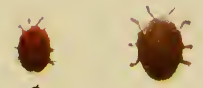

9
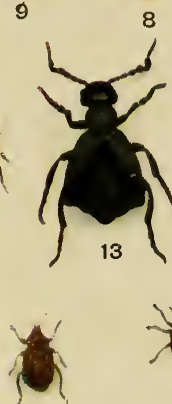

20
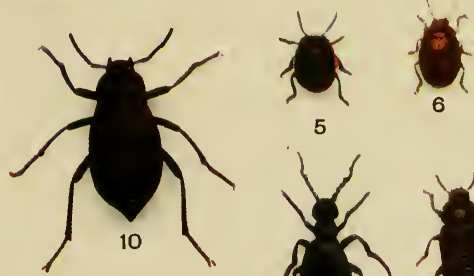

5
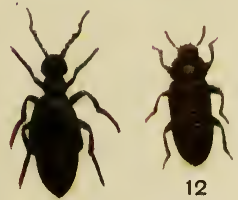

14

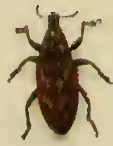

21

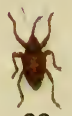

23

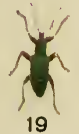

19

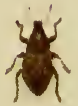

18

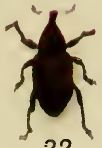

22

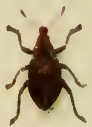

17

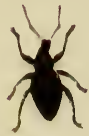

16
1. Donacia crassipes

2. Donacia semicuprea

3. Clythra quadripunctata

4. Trinarcha tenebricosa

5. Chrysomela marginalis

6. Chrysomela staphylea

7. Adimonia tanaceti

๖. Cassida equestris

9. Cassida viridis
10. Blaps mucronata Churchyard Beetle

11. Heliopathes gibbus

1) Tenebrio molitor (Meal-worm Beetle)

13. Meloe proscarabaus (Common Oil Beetle)

14. Meloe violaceus

15. Attelabus curculionoides Sre page 23.3.
16. Otiorrhynchus tenebricosus

17. 1.iophlceus nubilis

18. Barynotus obscurus

19. Phyllobius calcaratus

20. Hypera punctata

21. Cleonis sulcirostris

22. Hylobius abietis

23. Balaninus glandium 

out in a somewhat bushy fashion. The construction is much like that of a tiny bird's nest."

The American genus Himatidium has longer and more slender antennæ than the species of other genera, and its thorax does not conceal its head. H. latreillei is a beautiful bronzy-green colour, with an orange-brown thorax. The most remarkable Cassids are the tropical American species of Calaspidea. From Guiana hails C. grossa, with red elytra on which are depressed black dots and reticulations.

PRIONID 2 .-Front coxæ large and transverse; thorax with distinct side-margins; head not flattened in front; eyes kidney-shaped; antennæ long; mandibles very large, especially in the males.

These Beetles are somewhat reminiscent of the Stag Beetles (Lucanidoe), but they may always be distinguished by their antennæ. Many of them are of large size and of a curiously flattened form, and chestnutbrown is the prevailing colour. The sole British species, Prionus coriarius, is by no means common; it is a dwarf compared to some of the tropical species, seeing that it measures little more than an inch in length.

The largest species is the South American Titanus giganters. Well-grown specimens measure as much as seven inches in length and two inches across the folded elytra. This Beetle has short but powerful mandibles and a formidable spine on either side of its thorax.

From South America also hail some genera which depart from the sombre colouring usual to the family, and also the pale brown Macrodontias-insects with enormous toothed mandibles. All the larvæ are woodborers. 
Cerambycide.-Front coxæ not greatly extended transversely; thorax not margined; head produced in front, but never vertical; eyes always concave and more or less surrounding the hase of the antennæ.

The largest British Cerambycid is the Musk Beetle, Aromia moschata, a metallic-green insect with a spine on either side of its thorax. It is a sluggish insect, and may often be found sunning itself on the decaying wood of willows, on which its larvæ feed. When handled it emits a musk-like aroma; hence its name.

The genus Clytus, of which there are several European species, is notable on account of its remarkable mimicry of Wasps. Nearly all the species are black with yellow markings; all are active on the wing. Callichroma is a genus noted for the brilliant metallic blues and greens of most of the species. Some species of the South American genus Cosmosoma are peculiar in that their antennæ bear dense tufts of hair about midway along their length. Coremia hirtipes, another Cerambycid from the same country, has similar though denser tufts on the hind-tibiæ. It flies slowly over dead timber in new clearings, and when on the wing resembles a large Culex.

LAMIIDA.--Front coxæ usually round and deeply embedded; front tibiæ with a slanting groove on the inner side; head vertical, flattened in front; wings sometimes absent.

These Beetles may always be distinguished from those of the last family by the position of the head. The family is a large one, and contains some exceedingly ornate species.

Our largest British Lamiid is Saperda carcharias, a 


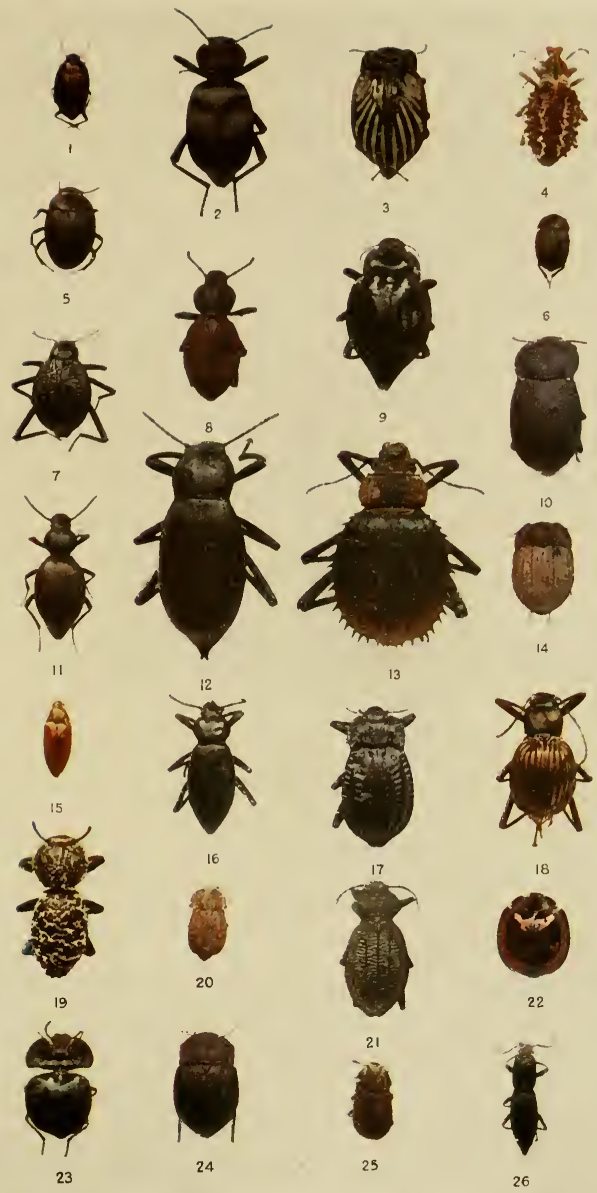

1. Zoplobas sp.

10. Blaps producta

11. Elcodes dentipes

12. Niachula buqueti

13. Asida silphoides

14. Gyriosomus luczoti

15. Nyctaclia levis

16. Prionotheca coronat

17. Epipedonota ebenina

18. Trachynotus sp.

19. Opatium subsulcatum

(1) Sudium wagneri

21. Praucis submetallicus

22. Platynotus evcavatus

23. Saragus lavicollis

24 Hegemonia fililu: ter

25. Hemicyclus granc'is
26. Dolichoderus Klugii

8. Akis elongata

9. Scotobius clathratus 

black insect densely clothed with yellowish down; its elytra terminate in a short spine, and it frequents willows and poplars. The largest species is the beautiful Brazilian Macropus longimanus. It is black marbled with red and grey, and its fore-legs are enormously developed in length; hence its name. Batocera is a common East Indian genus of large size, and most of the species are brown spotted with white. Nearly as large as any of the Batoceras is the African Petrognatha gigas, a grey species with a large black patch on the outer edge of each elytron. Monohammus is one of the largest genera of the order; it is of almost world-wide distribution, and most of the species are of sombre hue. Any description is inadequate to portray the beauty of form and the brilliant colouring of these elegant Beetles; a good representative collection alone can convey an idea of the wonders of the Lamiida.

\section{Series 6. Rhynchophora.}

ANTHRIBID ж.--Antennæ with a short first joint, not elbowed and often long; third tarsal joint small and partially concealed by the second joint; pygidium exposed.

Nearly all the species of this family are tropical, and one or two are agricultural pests of some notoriety. They are frequently confused with the Weevils, though the two families are quite distinct, as a comparison of our British Platyrrhinus latirostris with any Weevil will show. The species vary considerably in size; our native Choragus sheppardi is one of the smallest, and certain exotic species, with their antennæ included in their measurements, attain considerable dimensions 
Certain of these "long-horned" species bear considerable superficial resemblance to Longicorns.

All the Anthribidce are dull brown or grey coloured insects; frequently they are mottled, barred, spotted, or otherwise decorated with lighter shades.

CURCULIONID $\approx$.-Antennæ usually elbowed, first joint long; head prolonged into a beak of variable shape and dimensions; larvæ legless and usually curved.

The Weevils are undoubtedly the most harmful family of the Coleoptera. Larvæ and adults are vegetarians, and there is no part of a plant which is immune from the attacks of some species of Weevil; roots, stems, back, leaves, flowers, fruit, and seeds may any or all of them be attacked by Weevils. We can rarely eat our dessert without encountering the obnoxious larva of the Nut Weevil, Balaninus nucum. A near relative, the Acorn Weevil, $B$. glandium, does not force its attentions upon us to the same degree, because it feeds upon a fruit which is unfitted for human consumption.

The Pine Weevil, Hylobius abietis, has the character of being our worst forestry pest. It is peculiar for the reason that all the damage is caused by the adult Beetles, which eat the bark of Coniferous trees, so that it has the appearance of having been attacked by some rodent. The larvæ feed upon dead wood.

Weevils of the genus Anthonomus damage flowerbuds; Anthonomus grandis is the notorious Cotton Boll Weevil of America, a pest which had done more harm than any single species, and is only checked from further destruction by climatic reasons; it cannot withstand the climate of the more northern cotton fields. A. signatus lays its eggs in the buds of strawberry- 


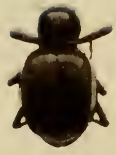

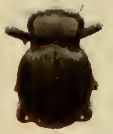

2
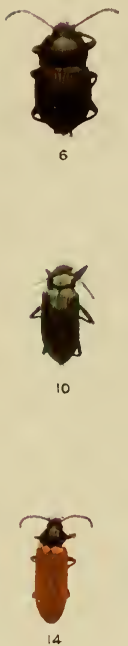

14
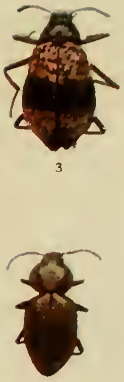

7
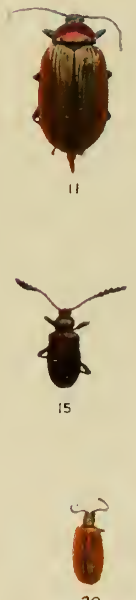

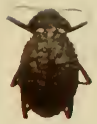

4
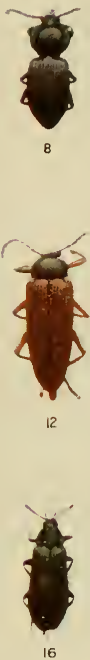

16

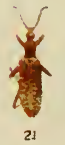

1. Moluris gibba

2. fonopus tibialis

3. Spheniscus erotyloides

4. Micrantereus a nomalus

5. Amarygmus sp.

6. Helops vulcanus

7. Adelium sp.

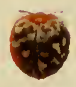

18

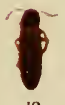

19
* Carduthorax walckenar

9 Sirongs lum bicolor

11) Strong lium sp.

11 Ne:ogena sp.

12 Nileculat sp.

13. Omophliss sp

14. Omophlius betula
15 Prostenus sp

16 Mclaudrya caraboides

17 Pytho depres:us

1s. Nilio lanatus

19. Pblocotrya rufipes

20. l.agria hirta

21. Statira sp. 

flowers, with the result that no fruit is formed; substituting apple for strawberry, similar remarks apply to the Apple Blossom Weevil, A. pomorum.

The Plum Weevil, Conotrachelus nenuphar, awaits in hiding till the fruit of plums, cherries, or peaches is formed. At this period the females make numerous holes in the fruit, and in each hole they deposit an egg. Needless to say, the larvæ feed upon and ruin the ripening fruit. Other Weevils which prefer the fruit to the flowers from which the fruit should arise, are the Grain Weevil, Calandra granaria, and the Rice Weevil, C. oryzce. These little pests, like some of the Bruchids, have been carried all over the world in the grain upon which they feed and in which they breed.

Some Weevils construct ingenious leafy nests for their larvæ. Of these, the work of the Birch Weevil, Rhynchites betulce, is a marvel of engineering skill. The ingeniously rolled leaves, cut and made into funnels by these insects, may often be seen upon young birch-trees during the summer months. Attelabus curculionoides is another, though less skilled, nest-builder. While searching for the Birch Weevil, there is every likelihood of finding a beautiful little emerald-green Weevil, Phyllobius calcaratus, which sometimes literally swarms upon our hedges. This little Beetle is one of our most beautiful native insects. Compared, however, with some of the exotic Weevils, exquisite insects of delicate blue and green hue, it is dingy.

Of the more sombre-coloured native Weevils we figure Otiorrhynchus tenebricosus; another hedge-frequenter in the shape of Liophlous nubilis; Barynotus obscurus, with a penchant for hiding beneath stones; 
Cleonus sulcirostris, a harmless species confining itself to thistles; and Hypera punctata, which is often taken at considerable distances from any food-plant.

Weevils are, for the most part, small or medium-sized Beetles. One or two species attain considerable dimensions, notably the Palm Weevil, Rhynchophorus palmarum, of the West Indies, whose fat grubs find some favour as human food. A short acquaintance with these insects in the field reveals a curious trait, common to nearly all species. When alarmed, instead of running away or taking to flight, they fall to the ground, curl up their legs, remain motionless and sham dead. This trait is especially common amongst the dullcoloured species, which, on account of their colour, are exceedingly hard to detect when they reach the ground. Scolytid ж.-Antennæ short and clubbed.

These Beetles are closely allied to certain of the Weevils. Nearly all of them are wood-borers, and many are exceedingly destructive.

To any but entomologists the Beetles are little known; to nearly everyone their work is familiar. There can be few people so little observant that they have never seen some tree with bark so loose that it easily peels away. Where stem and bark come in contact, the Beetles have made their tunnels in all directions, so that both parts of the tree are marked. The tunnels or burrows are very characteristic of the species which make them, and an expert can tell at a glance, from the nature and direction of the burrows, what species of Scolytid had carried out the work.

Some Scolytids, known as Ambrosia Beetles, fill their tunnels with a certain fungus, which thrives on the 


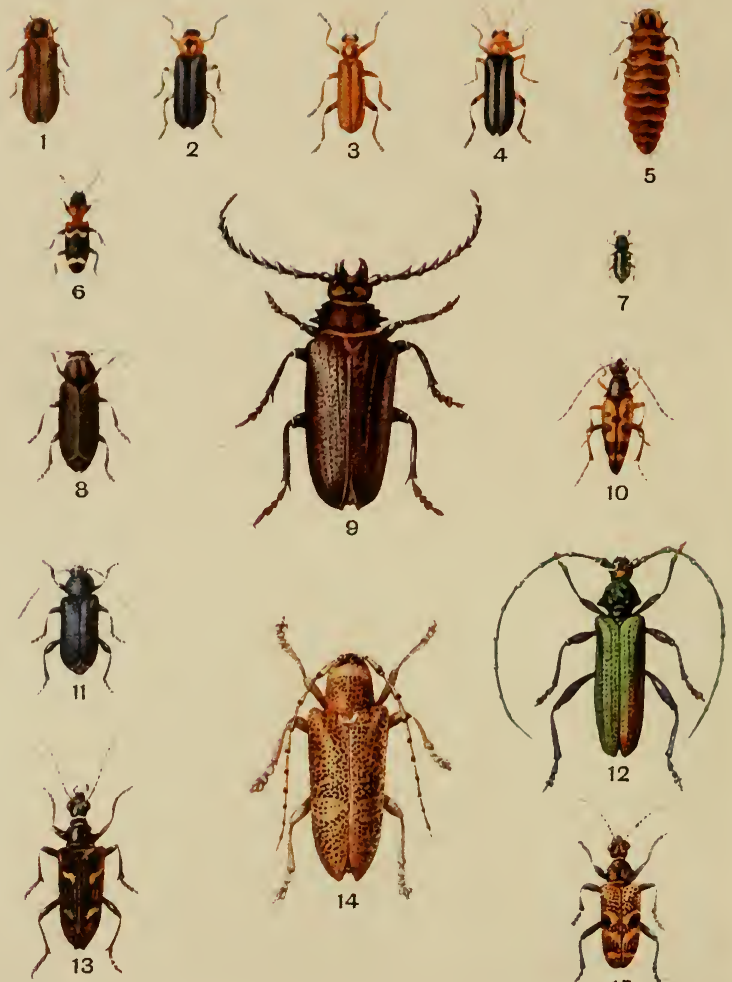

1 Lampyris noctiluca (male

2. Telephorus rusticus

3. Telephorus lividıs

4. Telephorus pellucidus

5. Lampyris noctuluca female
6. Thanasimus formicatius

7. Necrobia rufipes

ه. Asemum striatum

9) Prionus corinarius

10. Strangalia armata
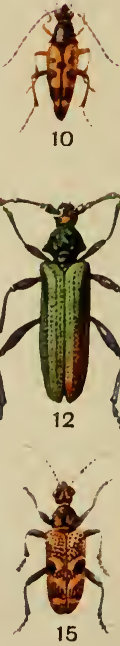

15 
exudations of the tree. The fungus serves as food for the Beetle larvæ; it renders the work of the insects more obnoxious to the forester, for the growth hastens the decay commenced by the excavations of the insects; it sometimes increases so rapidly as to choke up the tunnels and kill the inmates.

Among the common British Scolytidce, the Elm Bark Beetle, Scolytus destructor, is a serious pest, causing the bark of its food-plant to peel off in sheets. One species of tree may harbour several species of these Beetles. The Scots fir, for example, may have its uppermost shoots attacked by Pityogenes bidentatus, its young branches by Hylastes palliatus, its stem by Hylurgus piniperda, and its roots by Hylastes ater.

Of the deep-boring Scolytids, Beetles which do not confine themselves to the bark and subjacent parts, species of the genus Trypodendron are the worst offenders, and in Britain we have $T$. domesticum, partial to oak, beech, and birch, and $T$. lineatum, a pest of Conifers. Oaks are also frequently riddled by the all too common Xyleborus dispar.

All these Beetles, as may be inferred from their habits, are of small size; in colour they can show nothing beyond blacks and shades of brown. Though the injury caused by a single Beetle may be small, when, as is usual, the Scolytids appear in force their damage is widespread, and in America they have spread over areas so great as fifty thousand square miles and destroyed millions of feet of lumber.

BRENTHIDж. - Antennæ not elbowed; rostrum straight.

These most bizarre of all the Coleoptera are practically 
all confined to the tropics. It would be dificult to imagine more curious insects than certain of these Beetles. In some species the snouts are prolonged to an extraordinary extent. There are species in which the males have no snouts, but formidable mandibles instead. The females use their snouts to bore holes in wood for egg-laying purposes, and in this connection Sharp says that, in one species, the snout of the female is apt to become fixed during the operation. "The male then extricates her by pressing his heavy prosternum against the tip of her abdomen; the stout fore-legs of the female serve as a fulcrum and her long body as a lever, so that the effort of the male, exerted at one extremity of the body of the female, produces the required result at the other end of her body."

Certain species are exceedingly thin, elongated, and delicate. It is believed that all these attenuated species are carnivorous, and that their forms are specially adapted to enter the burrows of wood-boring insects for the purpose of preying upon the larvæ. The apices of the elytra in many species have curious prolongations whose utility is not known. The antennæ of all species are freely mobile on a ball-and-socket joint; they remain mobile even in the dried state.

\section{ORder Strepsiptera.}

STYLopidж.--Males small; fore-wings much reduced; hind-wings very large with radiating veins. Females minute sacs, the smaller end forming the head.

These curious parasitic insects are placed with the Coleoptera by many entomologists, including Sharp; here, however, they are considered as a distinct order, 
PLATE LXVII

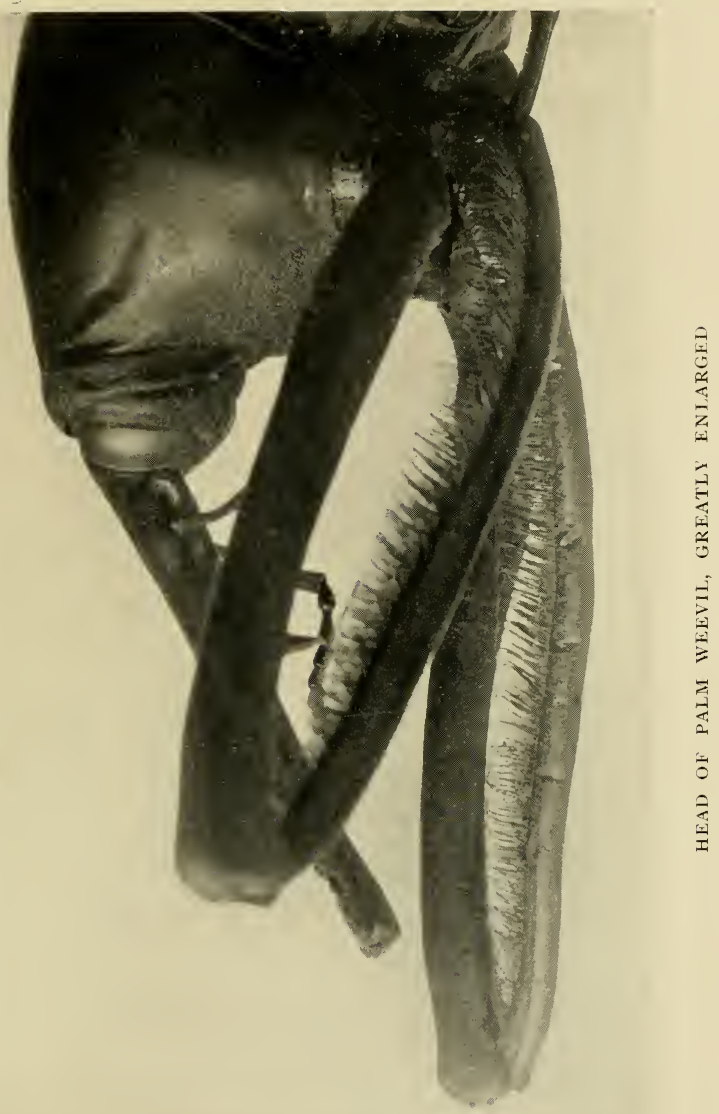



according to Nassonoff and Von Siebold. They are most aberrant creatures; all of them are parasitic on either Hymenoptera or Rhynchota. Of the latter forms practically nothing is known; of the former much remains to be learned.

Bees of the genus Halictus and Andrena and Wasps of the genus Polistes are specially liable to become "stylopized "-i.e., attacked by the parasite. Unlike many parasites, Stylops does not kill its host. The females may be seen projecting from between the abdominal segments of the Bee or Wasp, and so slight is our knowledge of these anomalous insects that it is uncertain whether the head or the tail end projects. Undoubtedly the most extraordinary effect of " stylopization" is that the secondary sexual characters of the host are affected. For instance, there are many species of Hymenoptera in which the males are of a totally different colour to the females. In the "stylopized "individuals of such species the males or females may not only fail to develop their characteristic colouring, but may even assume the livery of the opposite sex.

Exactly how the Strepsiptera reach their hosts has never been fully explained. In the genus Stylops, all the members of which are Hymenopterous parasites, the larvæ attack their host larvæ, penetrate below their skin, and both parasite and host develop concurrently. When the time arises for the host to pupate, the male parasite makes its change from the larval state in the manner common to other insects. The female parasite, on the other hand, remains within her host and at the right moment pushes her way between the latter's abdominal segments. The female Stylops never moves 
from the position she takes up at this juncture. The active males are short-lived; those of the genus Xenos exist for but a quarter of an hour; they lose no time in accomplishing their one object, the fertilizing of the immobile females.

Enormous numbers of larvæ are produced by each female. They crawl about over the body of their host in such numbers as to give it a powdered appearance.

In the case of social Bees and Wasps, it is an easy matter for the parasite larvæ to reach the host larvæ; in the case of the solitary Hymenoptera the young parasites must needs await some means of transport to the nest of a new host, for the " stylopized " females never build nests. Thousands must perish without ever finding a host; the fact that they are produced in thousands points to very considerable wastage. At any rate, the Stylops larvæ somehow contrive to attach themselves to the hair of a healthy insect, and she unwittingly conveys them to her nest. 


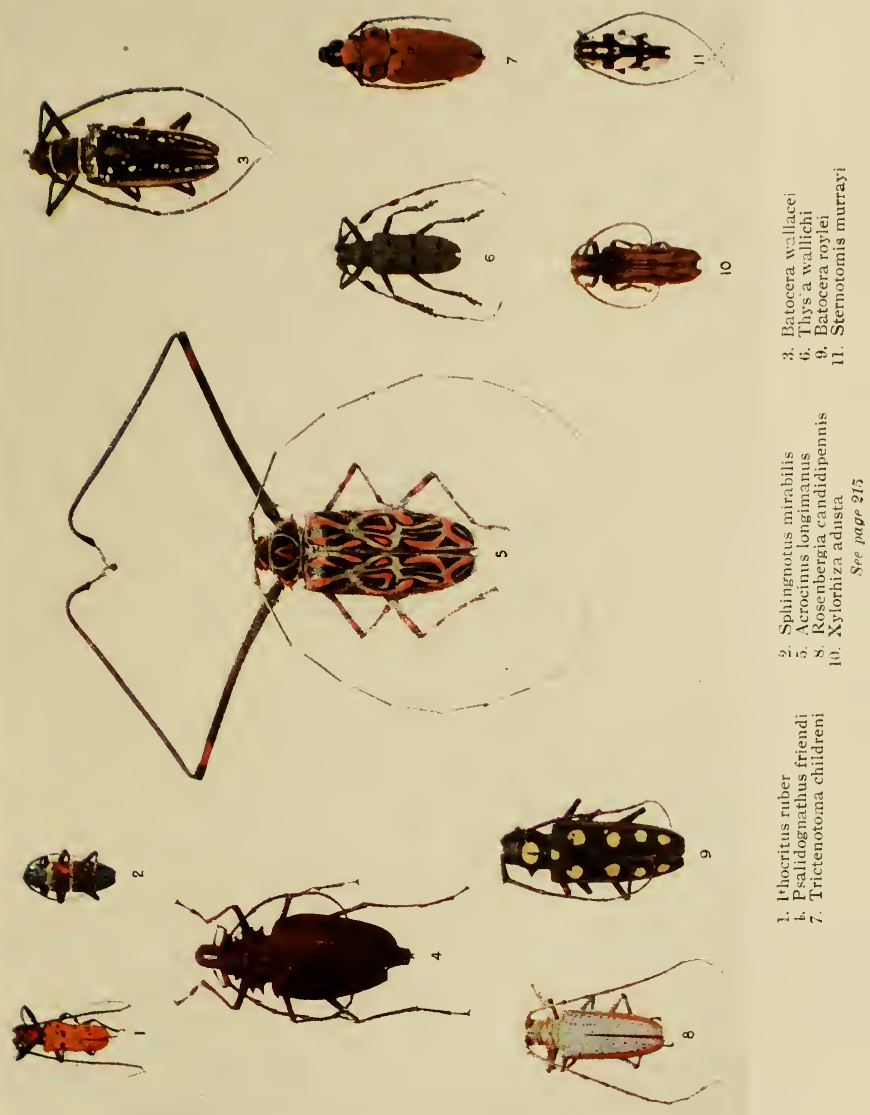





\section{CHAPTER VII \\ HYMENOPTERA}

INSECTS with four sparsely veined wings, often clothed with short bristles; mouth furnished with mandibles and proboscis; females with large ovipositors, often modified into a sting; metamorphosis complete.

This order includes the well-known Bees, Wasps, and Ants; its members, without exception, are of the greatest interest to the entomologist. Bees, Wasps, and Ants of many species have the social habit highly developed -in fact, these insects and the Termites are the only species which dwell in colonies. The solitary species of the order are no less interesting. The nests of certain solitary Bees are ingenious in the extreme; the methods by which some of the Sand Wasps store their nests with living, though benumbed, food would be beyond belief had not reliable witnesses testified to the veracity of the earlier observers. The story of Ants' guests, of Bee "cuckoos," and other invited and uninvited hangers-on, would fill a bulky volume in itself.

Most of the parasitic insects belong to this order. The life-histories of the Gall-flies, some species having a single generation of both sexes, some a single generation of females only, and others two generations, one 
of females only, the other of both sexes; the study of their curious galls-these and a thousand other details combine to make the Hymenoptera a most attractive order to the student of insect life.

The species comprising the order fall naturally into two suborders:

I. Sessiliventres.-Hymenoptera with the basal segments of the abdomen not constricted to form a "waist" or petiole, and ovipositors designed for boring or cutting, never for stinging.

II. Petiolata.--Hymenoptera with the basal segments of the abdomen constricted to form a "waist" or petiole; ovipositor usually a sting.

The Sessitiventres form a small division of but three families. Apart from the structural characters of the adults, the larvæ of the majority of these insects closely resemble those of Lepidoptera, except for their greater number of legs.

The Petiolata are divided into three series:

Series 1. Parasitica.-Ovipositors exserted or concealed, frequently of very great length; larvæ parasitic upon other insects.

Series 2. Tubulifera.-Terminal segments of the abdomen forming a retractile tube, in which a small, imperfect sting is situated; larvæ usually live in the nests of other Hymenoptera.

Series 3. Aculeata.-Very frequently the ovipositor is modified into a sting.

The Aculeata may be said to contain all the Hymenoptera which cannot be included in either the Parasitica or the Tubulifera. 


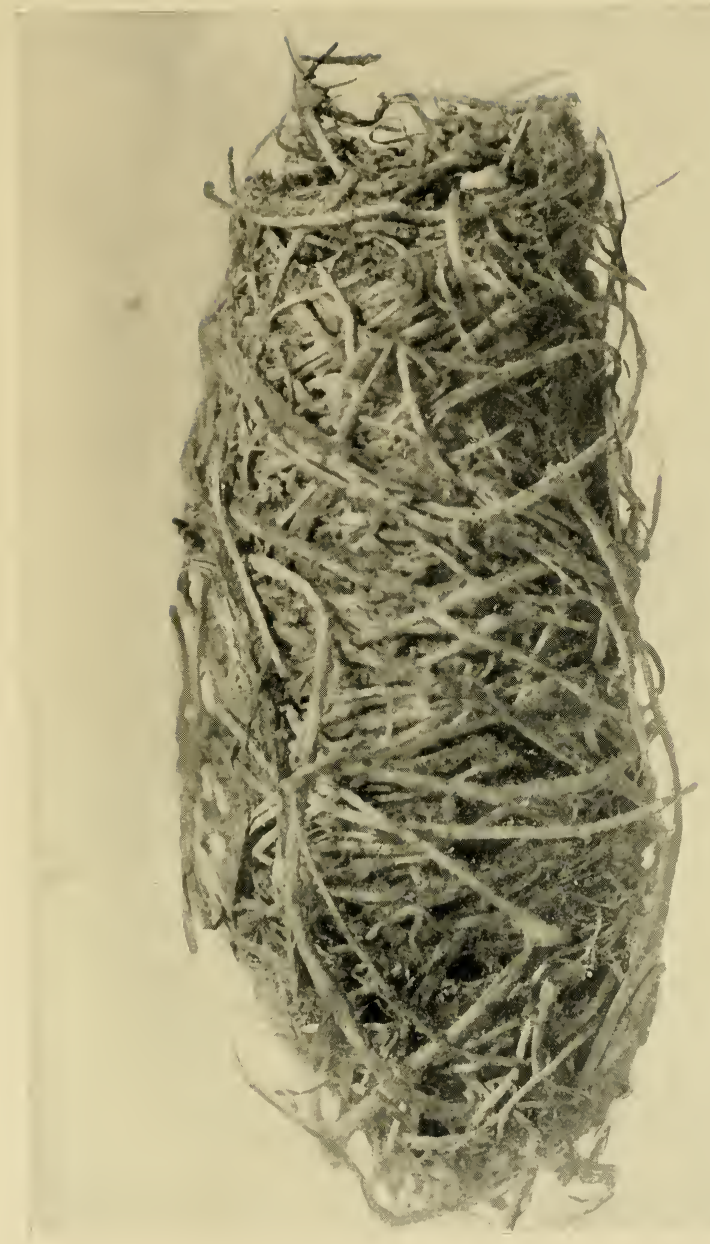

COCOON OF PALM WEEVIL 

SUBORDER SESSILIVENTRES.

This division is much smaller than Petiolata; to the latter division all the better-known families of the order belong. Here there are but three families of insects, for the most part inconspicuous, but also, with few exceptions, highly injurious.

TENTHREDINIDA.-Antennæ not elbowed, short; wings large and considerably veined; ovipositor sawlike; larvæ resemble those of Lepidoptera in form, but possess six to eight, in place of five, pairs of legs.

The Sawflies are so called on account of the structure of the ovipositor. Each of these organs consists of a pair of saws side by side, and their owner can move them up and down with a saw-like motion when she wishes to cut a slit in some plant tissue for the purpose of depositing her eggs therein. The majority of these insects are injurious pests among crops and in gardens.

Amongst the British species, of which there are many, the commonest and most destructive are the Currant Sawfly, Nematus ribesii, and the Gooseberry Sawfly, $N$. ventricosus, whose larvæ, being gregarious, rapidly defoliate currant and gooseberry bushes respectively. Two other common species of the same genus, $N$. gallicola and $N$. salicis-cinerece, form galls on willow-leaves, for the reason that the larvæ remain within the leaf-tissues instead of emerging to the surface.

Lophyrus pini is a common pest of Conifers; Hylatoma ros $\infty$, in its larval state, defoliates rose-bushes; its green Caterpillars are remarkably similar to those of Lepidoptera. There is no member of the family, however, 
more interesting than the Pear Slug, Eriocampoides limacina. The adult Sawfly is a shiny black insect, about a fifth of an inch in length. The female slits the under-side of a pear-leaf and deposits an egg in the pocket-like cavity thus formed. The egg hatches in a short time, having previously increased in size, probably owing to the assimilation of some of the juices of the leaf. The larva escapes from its pocket by making a semicircular cut in the upper surface; at first it is very pale yellow, almost white in colour. Very rapidly, however, the larva darkens in colour, for the reason that it covers itself with a dark olive-green, shiny secretion. At the same time it alters considerably in shape; its anterior end becomes swollen and its head retracted into the enlarged portion. Feeding takes place on the upper surface of the leaf, and consists not only of the leaf-tissue, but of the larval skin after each moult. When the last moult takes place the larva makes no meal of its skin, but leaves it upon the leaf. In colour it has changed to orange, and its body is no longer covered with slime. Crawling down the stem to the ground, the larva builds a little earthen cell for itself just below the surface; in this cell pupation takes place.

In addition to pear-trees, apple, cherry, and plum are also attacked by limacina. "Frequently the larvæ appear in such numbers as to do serious damage. Sometimes, when the slugs are very abundant, the sound of the eating of myriads of mouths resembles the falling of fine rain upon the leaves."

Parental care is so rare, except among the social insects, that the case of Perga lewisii, an Australian 
Sawfly, is worth quoting. The female deposits her eggs in slits near the midrib of a eucalyptus-leaf. "On this leaf the mother sits till the exclusion of the larvæ; and as soon as these are hatched the parent follows them, sitting with outstretched legs over her brood, protecting them from the attacks of parasites and other enemies with admirable perseverance."

SIRICID $\approx$.-Large insects with cylindrical, awl-like, exserted ovipositors; abdomens not constricted into a petiole at the base.

The Wood Wasps are conspicuous-looking insects, which, owing to their formidable-looking ovipositors, often strike terror into the person beholding them for the first time. In reality they are quite harmless to human beings, for they possess no sting.

The two species most frequently met with in Britain are the Giant Wood Wasp, Sirex gigas, and the Blue Wood Wasp, S. noctilio. In form the two species are very similar; in colour, gigas is black banded with yellow on the abdomen, whilst noctilio is of a dark metallic blue colour.

The females deposit their eggs in wood; they prefer Conifers, and usually only oviposit in felled timber. The larval life is considerably protracted, and all the while considerable tunnelling takes place, to the ultimate ruin of the timber.

In America the Pigeon Tremex, Tremex columba, has similar habits, but prefers living trees, especially maple.

CEPHID ж.-Antennæ long; wings large; ovipositor needle-like and exserted. Larvæ live in stems of plants.

The most notorious species of this family is Cephus 
pygmaeus. In some countries, on the Continent and in America, for instance, it does considerable damage. The female bores into wheat-stems with her ovipositor, lays her eggs therein, and the larvæ complete the work of destruction. Pygmceus is not common in this country.

The American Phyllaceus integer has a more interesting life-story: The female punctures a willow-twig just below the growing point with her ovipositor; she then directs that organ obliquely into the pith and deposits her eggs. Wisely, lest the growth of the willow should injure her eggs, she girdles the twigs just below the puncture she has made; this causes the death of the shoot, and its ruin for basket-making.

\section{SUBORDER PETIOLATA.}

\section{Series 1. Parasitica.}

ICHNEUMONIDE.-Antennæ with more than sixteen joints; abdomen constricted at the base into an elongated petiole, or not constricted; ovipositor often long and protruded.

The Ichneumon Flies as these insects are often wrongly termed, for they are not Flies, are all parasitic insects. The family is a large one, and is divided into a number of subfamilies. The order is by no means an easy one for the entomological student, and those who wish to attempt systematic work should not essay the effort unless they have access to a representative collection.

The methods of oviposition differ with the species; some deposit their eggs on the bodies of their hosts, 

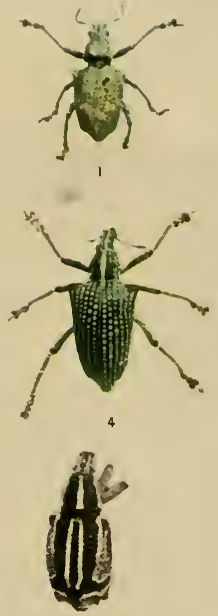

6

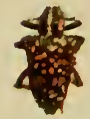

9

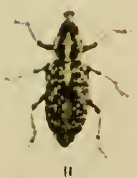

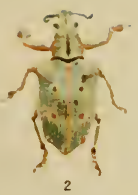
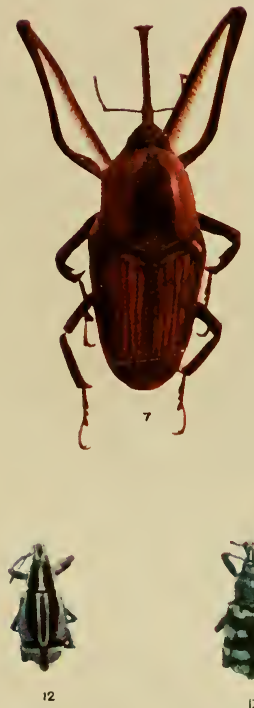

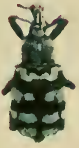

13

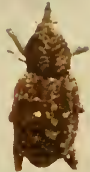

3
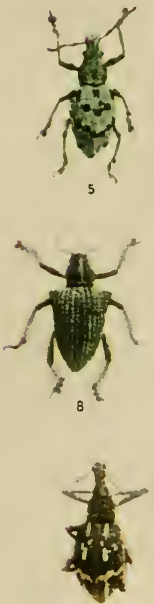

10

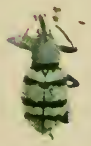

14

A GROUP OF IVEEVII.S

The figures give a good idea of the striking colouring which occurs in many species of this family No. 7 is the Palm Weevil, the largest of the Curculionidæ. 

some within them. In the majority of cases the larvæ of Lepidoptera are the hosts of these insects; a few species, however, prefer Beetles and others, Hymenoptera. Certain species of Pimpla, notably $P$. rufata and $P$. fairmairii, are known to be parasitic upon Spiders.

The long ovipositors of many of the Ichneumonida appear to be somewhat of a hindrance to their owners; there are species in which these organs measure as much as four inches. The true ovipositor is always protected by a sheath of four stylets equally as long as itself. Possibly all the species with inordinately developed ovipositors prey upon insects whose larvæ burrow in wood or some other medium. Certainly this is the case with the common British Rhyssa persuasoria, whose hosts are the larvæ of the Wood Wasp. Now, the Wood Wasp deposits its eggs in timber, and its larvæ make extensive and deep-seated tunnels in the same material. So deeply do they bore. that it is impossible for Rhyssa itself to reach them; it accomplishes its object, however, by the aid of its long ovipositor, which it plunges far into the recesses of the Wood Wasp's larval tunnels, and deposits its egg in its victim.

BRACONIDA.-Very similar to Ichneumonidae; antennæ generally with more than sixteen joints, the first and third being longer than the second; second and third abdominal segments fused.

This family has been neglected by entomologists, and from a systematic point of view is in a chaotic state. The species are frequently so similar to the Ichneumons that only the expert can separate the two families. Many exotic Braconida are exceedingly ornate insects, 
black and yellow or red and yellow being the prevailing colours of the family, though there are a number of self-coloured, red species.

The genus Aphidius includes several species parasitic upon Aphides; in consequence, they are insects to be protected. The commonest British species, at any rate the species whose activities are most easily observed, is Apanteles glomeratus, a parasite of the Cabbage White larvæ. This Braconid lays a number of eggs inside the body of its host, and its larvæ feed upon the fatty matter with which they are surrounded. When fully fed, the parasitic larvæ leave their host to spin small silken cocoons, in which they pupate. A. formosus makes curious stalked cocoons.

EvanIIDж.-Antennæ thirteen or fourteen jointed; abdomen attached to the upper part of the metathorax; ovipositor straight.

Species of the genus Evania can always be distinguished by their short, compressed abdomens attached by a slender petiole to the upper part of the thorax. In outline the female abdomen is triangular, that of the male oval. The colour of the Evaniids is invariably jet black.

These insects are widely distributed, probably because they are parasitic upon the eggs of Cockroaches. Evania appendigaster is the most widespread species. It is black; its fore-wings barely span an inch, and its hindlegs are quite twice the length of its body. The larvæ of this parasite live within and feed upon the yolk of the Common Cockroach's eggs.

The genus Fœnus is remarkable for the long, slender abdomens of its species, in striking contrast to those 
of Evania. Fœnus jaculator, a by no means uncommon insect, frequents the nests of Crabro and oviposits in its larvæ.

CHALCIDID ж.--Antennæ elbowed, usually six to thirteen jointed; wings but little veined.

This is the largest and most interesting family of the parasitic Hymenoptera. Nearly all the species are parasitic; a few, belonging to the genus Megastigmus, live in seeds, and some, of the genus Isosoma, are gallmakers. Till quite recently this family had been much neglected by British entomologists, for what reason it is difficult to say, unless the minute proportions of the majority of the species acted as a deterrent; it could not have been because the Chalcidida lacked interest. Howard, who has studied the family in America, says: " Nowhere in nature is there a more marked example of the correlation between structure and habits than occurs in this family. This correlation descends to the relation between the parasites and their hosts, so that it is possible for an experienced person, on secing a new species of Chalcis Fly, to tell precisely what kind of an insect it will be found to be parasitic upon." The babits of these Hymenoptera are so varied that it is impossible to take one as a type of all the family. Some species are parasitic upon Lepidopterous larvæ, some on Diptera, some on Bees-in fact, they are the most assiduous of all parasites, and the most catholic in their tastes. Many of them are of beautiful metallic sheen, and many also are interesting structurally. Species of Chalcis, for example, have their hind-femora so much thickened that they may equal the abdomen in size. Leucospis, a non-British genus, has species 
with ovipositors recurved over the back of the abdomen.

The utility of Chalcididae is not confined to their parasitic activities. In fig-growing countries the services of a species of Blastophaga are utilized to bring about the fertilization of the fig-flowers. The inflorescence of the fig is peculiar; the flowers grow within a hollow receptacle quite out of reach of the majority of insects. Blastophaga, however, enters the inflorescence, brings about fertilization, and thus causes the fruit to ripen. This semi-artificial fertilization of figs is known as " caprification."

The life-cycle of many Chalcids is completed very rapidly. Howard has carefully noted the time taken by Euplectrus comstockii to pass through its transformations. The egg stage lasted two days, the larval stage three, the pupal stage the same length of time, a complete generation in eight days. "It is altogether the shortest development of any Hymenopterous parasite that has been studied."

Podagrion pachymerus has the very interesting habit of sheltering below the wing of a female Mantis as she is forming her egg-mass. From this advantageous position the Chalcid can lay her eggs amongst those of the Mantis.

Proctotry PID \&.-Antennæ elbowed, ten to sixteen jointed; bodies long and slender; wings with very few veins.

These insects are even less known than the Chalcidida ; as a family they are the smallest of all insects. Some idea of their size may be gleaned when we learn that sometimes as many as six larvæ may live within a single Lepidopterous egg, feeding upon the yolk and 
undergoing all their transformations therein. Another genus, Trichacis, possesses species that " develop in the nervous system of one of the little gall midges, while the larvæ of another genus, Polygnotus, develop in the digestive tract of the same insect." Spiders' eggs, also those of Lepidoptera and Coleoptera, are parasitized by Proctotrypids; they also live in the larvæ of Diptera, Coleoptera, and small Hymenoptera.

Marchal described a curious life-history of a species of Encyrtus. The insect lays its egg within that of a Tineid Moth, and, instead of a single Encyrtus larva appearing, as might be expected, a number hatch from the single egg, owing to this egg becoming divided into a number of embryos.

CyNIPID s.-Antennæ straight, thirteen to fifteen jointed; wings with few veins; ovipositor concealed.

The Gall Flies, so called, are not by any means the only gall-makers in the insect world, nor, indeed, are all the Cynipida gall-makers, for some species are parasitic upon Aphids and larvæ of Diptera.

For a long time it was thought that no male Gall Flies existed; to this day the males of some species have never been discovered, but it is highly probable that in these species time and research will show them to have a spring brood of females and an autumn brood of both sexes, a common happening with Gall Flies. The alternation of generations, so common amongst Cynipidoe, has led to further confusion, and many of the spring broods have been described as different species to the autumn broods. The preponderance of females is of advantage to the insects, for they are much attacked by parasites, mainly Chalcididoe; this, again, is yet 
another factor making the study of Gall Flies difficult, for frequently parasites instead of the rightful owners appear from the galls.

"One of the most peculiar facts connected with the Gall Flies is that a particular part of the plant is always affected by the same species, and that each species of the same generation always produces a deformation or gall of exactly the same character, so that the gall alone identifies the species of insect, and, in fact, for a long time generic and specific names were given to the galls before the insects were named."

Many theories have been suggested to account for the formation of galls by these insects. No gall begins to develop till the larva hatches from the egg, and it is probable that the larva excretes some substance which causes the rapid growth of the plant cells in its immediate vicinity. The oak is the tree most favoured by Gall Flies; there are twenty-four quite common oak galls, and many more less frequently met with. One of the most curious of our native galls is the Bedeguar Gall, or "Robin's Pin Cushion," formed by Rhodites rosa, which deposits its eggs in a leaf-bud, with the result that, instead of the formation of normal leaves, the well-known, characteristic green or red hairy galls are formed.

\section{SERIES 2. Tubulifera.}

ChrysmID A.-Cuckoo Flies or Ruby Wasps. Insects with hard, often deeply sculptured, metallic green or blue dorsal integuments; antennæ thirteen-jointed and elbowed. Terminal abdominal segments in the form of a tube, which can be retracted or extruded; hence the name of the series. 
Before going further, it is well to remark that these insects are not Flies, as their popular name suggests. Many insects, Dragon-flies, May-flies, and Green Flies, amongst others, are not Flies, but still they bear titles to which they have no right.

The Ruby Wasps are easily recognized; their brilliant colouring of metallic sheen, often with ruby-tipped abdomens, and their ceaseless activity, render them conspicuous. All the score of British species are small, and no members of the family attain large size. They are widely distributed over the world, and all of them deposit their eggs in the nests of other Hymenoptera; hence their name of Cuckoo Flies.

The majority of Chrysids are parasitic upon the Mud Wasps, Odynerus. These little solitary Wasps leave their nests exposed while they hunt for provender with which to stock their larders, so the evil work of the Cuckoo Flies is easily accomplished. Our native Chrysis ignita deposits its eggs in the nests of the Mud Wasp, Odynerus parietum; C. bidentata favours the home of O. spinipes. The former Cuckoo Fly has been observed to deposit a single egg in the nest of its host; the latter lays as many as ten in each nest, but invariably all except one are infertile. In both cases-in fact, in every observed case of parasitism by these insectstheir larvæ feed upon the larvæ of their hosts. It is remarkable also that, except by colour, it is almost impossible to tell the white parasite larva from the yellow host larva.

An American species, C. ccerulans, is parasitic upon the Potter Wasp, Eumenes fraterna. Sometimes, as Howard remarks, there is confusion in the host nest. 
Odynerus goes in search of food, and leaves its cell unguarded; along comes a Trypoxylon-a Sphegid with Cuckoo habits-and stores the host cell with its own provisions, closing the entrance against the return of the owner. On the arrival of the Odynerus her first care is to open the cell once more; having done so, further food must be found, and while she is away Chrysis comes on the scene, deposits an egg in the newly opened cell, from which a larva emerges that is destined to survive the progeny of host and primary parasite.

To the genus Cleptes belong the only species of the family capable of stinging Not only so, but in general form they more closely resemble the aculeate Hymenoptera than do the other Cuckoo Flies. They are parasitic upon Sawflies.

\section{Series 3. Aculeata.}

This series is somewhat artificial, since it does not include all the Hymenoptera capable of stinging. Various other suggestions have been made for the better classification, and many of them are worthy of every consideration. The arrangement adopted here, however, is generally accepted, so that at least it has the merit of popular approval.

The Aculeates are subdivided into four divisions:

1. Anthophila, or Bees.-Body clothed, in part with plumose hairs; mouth-parts elongated and usually tubular, flexible at the tip. Adults all winged. Often dwell in societies.

2. DiPloptera, or WASPS.-Anterior wings folded longitudinally when at rest; no scales or nodes on the 


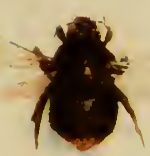

I
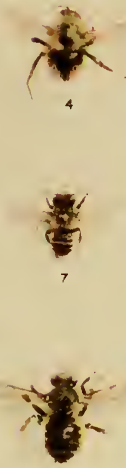

9

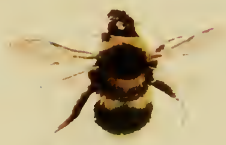

12

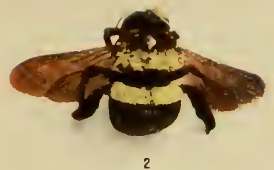

2

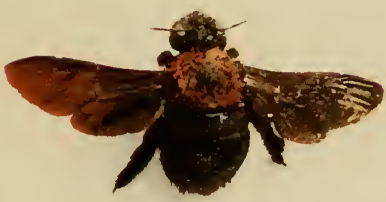

5

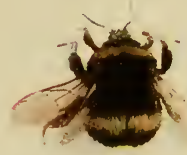

10

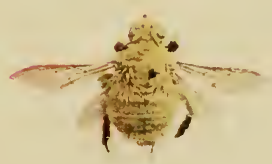

13

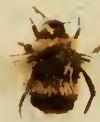

3
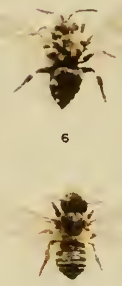

a

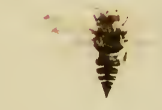

i1

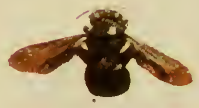

14
1 Bombus lepidarius

4. Bombus venustus

7. Halictus rubicundus

9. Merachile sp.

12. Bombus lucorum
A GROUP OF BEES

2. Bombus hortorum

5. Xylocopa sp.

11). Bombus terrestris

13. Nylocopa sp.
3. Bombus muscorum
6. Anthophora sp.
*. Megachile sp
11. Cuelioxys sp.
11. Apathus vestalis 

basal segments of the hind-body; hind-tarsi designed for walking. Either dwelling in societies or solitary.

3. Fossores, or Digaer Wasps.-No plumose hairs on body; no longitudinally folded wings; no scales or nodes on basal segments of the hind-body.

4. Formicid $x$, or ANTs.--The segment or two segments behind the posterior part of the thorax either small or irregular and very mobile; trochanters not divided. Live in colonies.

Division 1. Anthophila, or Bees.

Bees are nearly always hairy insects; they have peculiarly modified mouth-parts, which serve their owners and entomologists a good purpose in collecting nectar and in forming a guide to classification respectively; their hind-legs are modified-greatly so in some species. The peculiar plumose hairs with which many Bees are clothed presumably assist in the collection of pollen, and the presumption is strengthened by the fact that many parasitic Bees, which gather no pollen, are destitute of these hairs. Some parasitic Bees, however, possess these hairs, and opponents of the pollen-collecting theory have not been slow to point to these species as confirmation of their own assumption that feathery hairs are not designed for gathering food. That pollen does adhere to these modified hairs is by the way.

As already remarked, the tongues of Bees are used for taking up nectar. They are complex organs, and these pages are not the place to enter into minute anatomical details. There are three types of Bee tongue-(a) short and forked, (b) short and pointed, (c) long and pointed. With these organs the insects 
take up nectar and swallow it; it passes to the honeysac, where it remains till the Bee returns to her nest, where it is regurgitated as honey. During the period in the honey-sac part of the water is removed, and various secretions, including formic acid, which acts

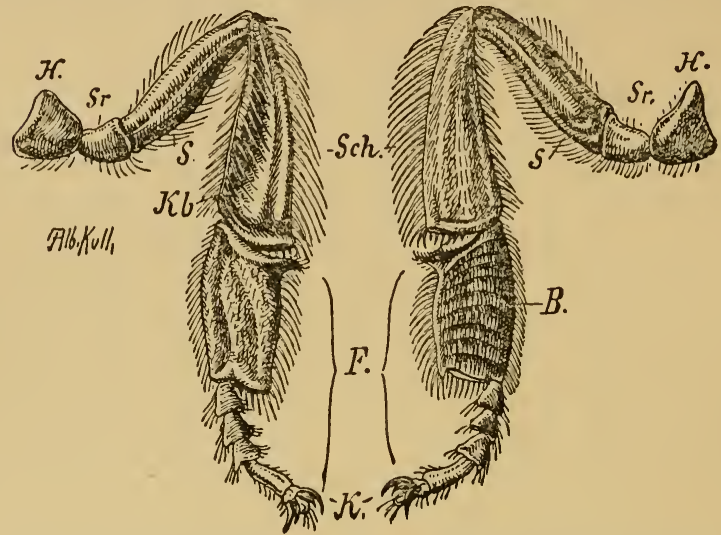

Fig. 12.-Left Hind-Leg of a Working Fumale Honey-Bee (Strongly Magnified).

On the left, viewed from the outer side; on the right, viewed from the inner side. $S$, Femur; $S c h$, tibia; $F$, foot; $K$, two pointed claws with balls between them; $K b$, pollen-basket; $B$, brush.

as a preservative, are added from glands of the bee. The regurgitated honey requires further treatment before it is fit for consumption.

The legs of Bees are beautifully modified to suit the work of their owners. The hind-legs show the greatest variation from the normal, especially in the females, for on these organs the pollen is mainly carried. Those Bees which carry dry pollen have densely haired hind- 
legs; those which carry the paste-like " Bee bread," a mixture of pollen and nectar, have hollowed tibiæ edged with stiff bristles_-" pollen-baskets"-in which to carry their burdens. Males and parasitic Bees do not possess pollen-carrying modifications, and where drones exist they also are destitute of these appendages.

The young larvæ of all Bees, whether Solitary or Social, are reared in nests or cells constructed either by the parent Bee or by workers, or, in the case of parasitic Bees, by some other insect. They are never exposed and left to their own devices, as, for instance, are Lepidopterous larvæ. The Social Bees feed their larvæ upon honey and pollen, after the manner of birds; Solitary Bees store sufficient food for the needs of their young, deposit an egg on the stored food, and seal up the cell, leaving the larva to fend for itself. Parasitic Bees usually lay their eggs in the cell of some Solitary Bee; their larvæ always either hatch first or grow quicker than those of their hosts, so they are well provided for by their host's food store and, if necessary, its egg or larva. With the exception of these parasitic Bees, which sometimes eat their host's progeny, all larval Bees are fed upon vegetable matter or material of vegetable origin.

The classification of Bees is in a most unsatisfactory state. To avoid confusion as far as possible, we treat of these insects in two sections-(1) the Solitary and (2) the Social Bees.

\section{Solitary Bees.}

Short Forked-Tongued BeEs. - Archiapidae of Friese. We have sixteen species of these Bees in Britain, all belonging either to the genus Colletes or to Prosopis. 
Of the latter genus there are ten British species; they have earned their generic name from the white faces of the males. They are all small, almost nonhairy creatures, and their hind-legs are not modified for carrying pollen. In general colour they are invariably black, and most of them emit a pleasant odour. They usually construct their cells in the pith of bramble stems, and cut or broken ends of these stems are in much request by the little Bees. Each cell is lined with a thin membrane, and is stored with a mixture of honey and pollen. The latter is swallowed by the female along with the nectar, being swept to her mouth by her hairy front legs. Frequently a Chrysid larva usurps the Prosopid cell; they may often be found living on the stores of our commonest species, Prosopis signata.

The genus Colletes is smaller, so far as this country is concerned, for we can only boast of half a dozen species. In general appearance these moderate-sized Bees closely resemble the genus Andrena. With a single exception they are all well clothed with brown hair; the middle and hind legs of the females bear pollen-carrying hairs. Their nesting habits are peculiar. They burrow in the ground, making unbranched tunnels, which they line with a membranous substance, which, by the way, is of glue-like consistency when first formed; hence the name of the genus. The burrows are then divided into separate cells, six to eight in number, by the same material, and each one is filled with semi-liquid food in which an egg is deposited.

Colletes, of which our commonest species is $C$. succincta, is subject to the attentions of a "cuckoo," just as is Prosopis, but in this case it is not a Ruby Wasp, 
but a long-tongued Bee of the genus Epeolus, which shares, or rather usurps, its home. Sometimes host and parasite frequent the same flowers. Tansy is the favourite of Colletes daviesanus and its "cuckoo," Epeolus variegatus.

ANDRENID A.-Short pointed-tongued Bees.

This is the largest section of British Bees, no fewer than a hundred and twenty species belonging thereto. The largest native genus is Andrena, containing about fifty species. In appearance these Bees closely resemble Honey Bees, but they are smaller. They are among the first insects on the wing in the spring. Their nests are always made in the ground, frequently in gravel paths, and, though true Solitary Bees, they frequently nest in close proximity to one another.

One of the earliest Andrenas to appear is the little red Andrena fulva, an attractive little creature, whose burrowing habits may easily be observed. These early arrivals have hibernated below ground through the winter. As soon as they arouse themselves they set to work to make nests for their own families. Tunnels, often a foot in length, are made in the earth, and from the main shaft numerous side-galleries are run; in each one, before it is closed, there is deposited an egg and a store of pollen and honey. By summer the eggs are hatched and the larvæ are fully fed; in early autumn the perfect insects have emerged from the pupæ, but they remain in their subterranean homes till the first warm days of spring summon them to activity.

A. vicina passes through its life-cycle more rapidly, and the adults are on the wing in the summer. $A$. argentata, resplendent in its silvery hirsute clothing, is 
another late Andrena, for it may be seen assiduously collecting nectar from heather-flowers late in August.

The Andrenas are preyed upon by "cuckoos" of the genus Nomada. These Bees, which are invariably of a yellow and black or red and black colour, appear to live on the most friendly terms-at any rate, the attentions of the "cuckoos" are never resented. The Nomada have few hairs, and their legs are not adapted for carrying pollen. All the species are parasitic, and their hosts are always Andrenas. Friese relates that he has frequently seen Nomada lathburiana and Andrena ovina flying about together.

Reference has been made to the friendly relations of host and parasite, and the fact may seem strange. Further consideration shows that, after all, the phenomenon is not so peculiar as it appears at first. The parasites do not interfere with their hosts, and the latter do not feed their larvæ from time to time, as do the social insects. "The Wild Bee that seals up its cell when it has laid an egg therein, and then leaves it for ever, has no conception of the form of its progeny; never in the history of the race of the Andrena has a larva seen a perfect insect and survived thereafter; never has a perfect insect seen a larva."

The genus Halictus includes our smallest British Bees, and they are interesting also from another point, for in them we see the beginnings of a social life. A common burrow serves for several females; each sidegallery is the preserve of one individual, but the single front-door is the thin end of the wedge. "A sentinel is often stationed at the entrance, and there is close behind the doorway a small recess into which the sentinel can 
step whenever she wishes to allow a member of the establishment to pass in or out." This semi-social condition is specially developed in Halictus lineolatus and $H$. sexcinctus.

These Bees are but slightly clothed with hair, and some of them, especially the exotic species, are of dark metallic hue. Some species appear to have more than one generation a year, but our commonest species, II. morio, is only one-brooded. A striking peculiarity of these Bees, which cannot fail to strike the collector, is that females only are taken in the spring, and that later in the year males preponderate. The nests of $H$. quadricinctus and of $H$. maculatus have been minutely described by Verhoeff, and it is to be regretted that lack of space forbids our quoting him.

Just as Andrena had its " cuckoos," so has Halictus ; in this case they are Bees of the genus Sphecodes. These Bees appear to be on the border-line between criminal and decent living habits. Some authorities deny their parasitic propensities; they are ill-fitted for ordinary Bee labour, having very slightly developed pollencollecting apparatus. It is doubtful, however, whether Sphecodes is, generally, degenerating into an evil-doer or is struggling to lead a better life as a law-abiding Bee. It is against them that $S$. rubicundus has been taken from the nest of $H$. quadricinctus, and $S$. subquadratus has been observed fighting with $H$. malachurus, prior to taking possession of the latter's nest. Evidently the relations between Halictus and Sphecodes are not so friendly as between Andrena and Nomada.

All the species of this genus are small, brilliant, polished insects with red and black or red abdomens; 
one of our commonest species, $S$. gibbus, is very typical of the genus.

The genus Dasypoda contains one of the most striking of our native Bees, D. hirtipes. A large Andrena-like insect, its body is heavily clothed with tawny hair, its black abdomen is banded with white hair, and the hind-legs of the female bear exceedingly long, bright golden tufts of branched hairs, which give the insect its striking appearance.

Dasypoda tunnels in the earth to the depth of two feet or so. At the end of her burrow she constructs half a dozen chambers, in each of which she places food and an egg. The pollen which forms the larval food is carried to the nest on the hairy legs of the mother Bee; frequently her load weighs half as much as herself. In the nest she moistens her burden with honey, kneads it to a pasty mass, and rolls it into a ball. This operation is repeated with load after load, each subsequent load being added to the first, as a schoolboy builds up a big snowball, till a large-sized pollen-ball is formed. Three feet are made of the same material, to raise the ball from the floor, and an egg is laid on the top. The larva hatches from the egg in a few days, and finds itself upon a food-mass nearly a hundred and fifty times bigger than its own body. It devours the food layer by layer, so that the mass may retain its shape, and it voids no excrement till the whole is eaten.

APID $\approx$.-LLong pointed-tongued Bees.

This section, so far as our native Bees are concerned, is rich in genera, but poor in species, there being less than fifty, including the social species.

Anthophora is a large and widely distributed genus. 
Our native $A$. pilipes, a very early spring arrival, bears a remarkable resemblance to a small Bumble Bee. The black, hairy females have orange legs, and may easily be distinguished from the chestnut-brown males, whose middle legs bear long grey and black hairs. Their nests consist of short burrows in sand or clay banks, and the few cells they contain are lined with clay by the mother Bee. One species, A. personata, is said to require two years to complete its lifecycle.

This genus has its "cuckoos" of the genus Melecta, and $A$. pilipes is favoured by the attentions of the closely related though dissimilar $M$. armata, a slightly hairy, somewhat elongated insect, whose black abdomen is marked laterally with white spots. In this case the relations between host and parasite appear friendly, but another species of Anthophora has been observed to resent the attentions of $M$. luctuosa.

The Carpenter Bees, Xylocopa, are the largest members of the family, some of the tropical species measuring nearly two inches in length. They have broad, somewhat flattened bodies, sparsely clothed with hair on their abdomens, except on the edges, and in colour they are mostly black or blue-black. There are few European species, of which the most widely distributed is Xylocopa violacea; none of them occur in Britain.

Their popular name is derived from their habit of making tunnels in dead wood for nesting purposes. These Bees display an extraordinary amount of patience in making their cylindrical burrows and their galleries. All the work is accomplished by their powerful mandibles, and the cells of the galleries, each containing 
an egg and food, are all separated by partitions formed of saliva and wood shavings.

Euglossa is a tropical American genus, noted for and named from the inordinate length of the proboscis, often exceeding the length of the insect's body. Flattened, plate-like tibiæ, highly polished on their outer surfaces and fringed with bristles, are also characteristic of the genus. The colouring of many of these Bees is beautiful in the extreme, metallic greens, purple, violet, and gold, being mingled in perfect harmony.

Chalcicodoma is another interesting genus not represented in this country. The members of this genus are known as Mason Bees, a name, by the way, which is also applied to species of the genus Osmia.

The nesting habits of Chalcicodoma muraria may be taken as typical of the genus. The nest is built upon some solid foundation, a stone for preference. At first a single cell is built of earth mixed with saliva and incorporated with carefully selected small stones. After the edifice has reached the height of an inch or so, food in the shape of honey and pollen-the latter carried on the ventral abdominal hairs-is placed within to the height of about half an inch, an egg is deposited on the food, and the cell is closed. Nearly a dozen of these cells are made, and the whole group is then covered with a dome-shaped cement shelter " about the size of half an orange." In spite of their protection, the larvæ of these Bees are parasitized by the Chalcids Leucospis gigas and Monodontomerus nitidus, which perforate the shelters and cell caps; by the Bee Stelis nasuta, which does likewise; and by another Bee, 
Dioxys cincta, which lays its eggs in Chalcicodoma's stored food before the cells are conipleted. In fact, sixteen or more insects are known to prey upon C. muraria.

Of the Carder Bees we have but a single species, the Wool Carder, Anthidium manicatum, in Britain. It is a sturdily built black Bee, with yellow abdominal markings which give it somewhat of a Wasp-like appearance. It uses the burrows of other insects, or seeks out some naturally formed hole which will serve its purpose, and lines its nest with "wool " derived from hairy plants. The nest-cavity is doubly lined, first with rough wool, then comes an inner, finer layer of the same material, which is cemented to retain the honey stored within. A. diadema lines hollow stems with vegetable wool, and divides the cavity thus lined into several chambers. A. septemdentatum and A. bellicosum nest in discarded Snail-shells, and instead of using wool they close their nests with resin. These Bees all possess pollen-carrying hairs on their ventral abdominal segments.

The genus Osmia is noted for the remarkably varied nesting habits of its species. They are all short, stoutly built insects with very long tongues, and their ventral segments are densely clothed with pollen-carrying hairs, which are frequently brightly coloured.

Osmia bicolor frequently nests in Snail-shells, after the manner of some of the Anthidiums. O. rufa, recognized by its orange coat and horn-like protuberance on its face, either selects a similar site or some cavity in a wall or burrows in the ground. O. leucomelana usually and $O$. tridentata invariably nest in 
bramble-stems after having hollowed out the pith. The cells of these nests are placed in line along the pith and always the farthest cell from the mouth is the first to be completed. This being so, it is not surprising that the Bee in the end cell is the first to be ready to emerge. It bites through the partition which separates it from the neighbouring cell, and if its neighbour be ready to depart also, all is well. If it encounters a pupa it will patiently await its development and departure. Should the vigil be long-continued, by biting away the surrounding pith it will attempt to make a larger hole and room to pass. Should failure ensue, further waiting is cheerfully accepted; one individual will never damage another in its attempts to escape. This trait led Fabre to make the very interesting discovery that, though the Osmias are not averse to bringing harm to other insects, they will never injure their own species. The "cuckoos" of Osmia belong to the genus Stelis. We have already mentioned $S$. nasuta, which deposits several eggs in each cell of the Mason Bee, after breaking down the latter's masonry. S. minuta deposits a single egg in the cell of $O$. leucomelana. The larvæ of host and parasite live for a time upon the stored food of the host mother; the Stelis larva grows quicker than its companion, and with the consumption of the last remnants of food host and parasite meet; a short struggle ensues, in which the latter is always victorious; he devours his victim. Stelis signata is parasitic upon Anthidium strigatum, which it closely resembles-so closely that this Stelis was for long considered to be an Anthidium.

The Leaf-Cutter Bees, Megachile, are the most 


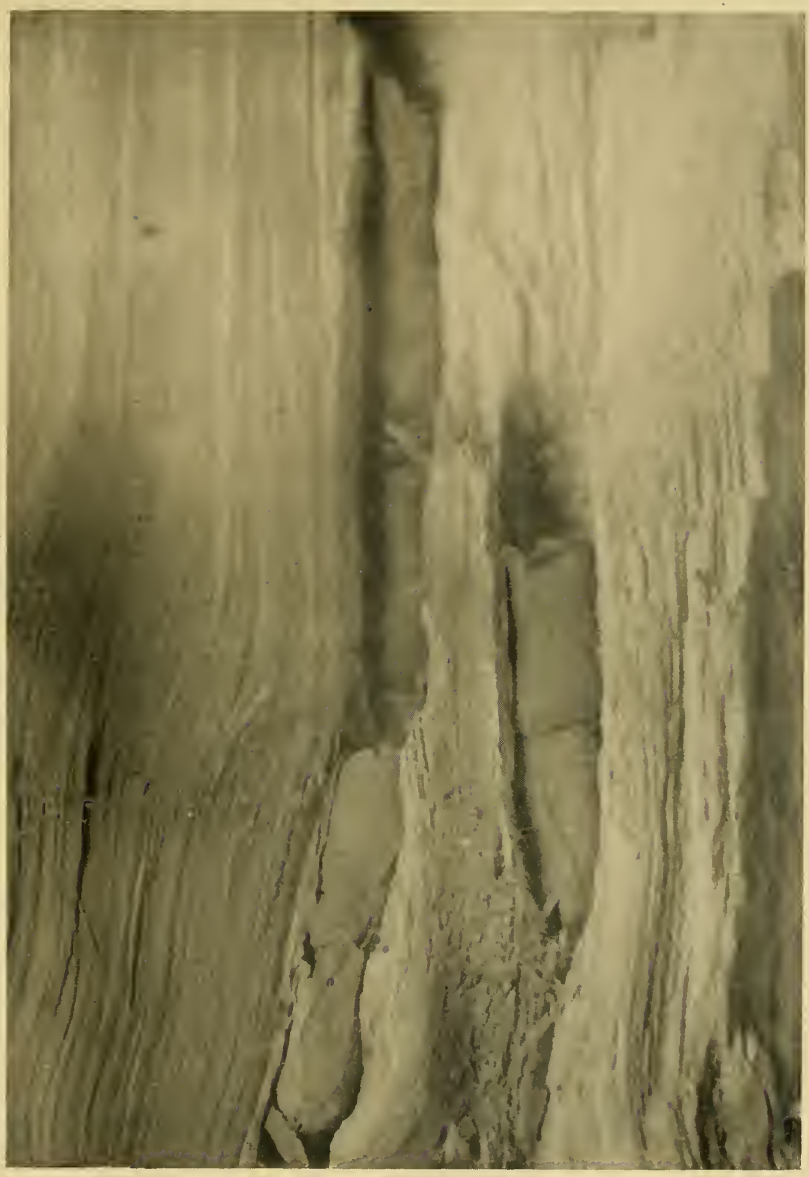

NEST OF LEAF.CUTTER BEE

The plate shows three series of cells arranged in borings in wood 

interesting of all the Solitary Bees. We have eight species in this country, and they resemble stout Honey Bees; they have wide heads, and their pollen-bearing hairs are situated on their ventral abdominal segments. As with Osmias, these Bees rarely make burrows of their own, but search for suitable natural resting-places or appropriate the discarded burrow of some other creature. Megachile albocincta nests in old Farth-Worm burrows; $M$. circumcincta bores a tunnel in rotten wood. All of the species, however, line their nests most ingeniously with portions of leaves or petals. The nests are composed of thimble-shaped cells formed of leaves and placed end to end along the burrow. The circular pieces of leaf are cut by the Bees with mathematical exactness; pieces of varying size are used for the end, the sides, and the top of each cell, and the leaf-edges are glued together by a waxy substance derived from the body of the mother Bee. Each cell contains a store of pollen and honey and an egg.

The "cuckoos" of Megachile belong to the genus Coelioxys, C. quadridentata being the special " cuckoo" of $M$. circumcincta. These Bees are quite distinct, usually of a black or dark blue ground colour prettily marked with pale blue; non- or very slightly hairy, and with rather acutely pointed bodies.

Eucera longicornis, the Long-Horned Bee, is a large insect of a chestnut-brown colour, and is rendered conspicuous by the enormous development of the antennæ in the males. The females have these organs of ordinary proportions. It nests in the earth in an enlarged chamber at the end of a short burrow.

Saropoda bimaculata, another of our Solitary Bees, is, 
curiously enough, most easily recognized by the distinctive high pitch of its buzz. It is an active insect which nests in the ground, and is possessed of lovely greenish-blue eyes.

\section{Social Bees.}

These insects differ from all the preceding species in the important fact that they dwell together in communities, in which there are at least a fertile female or "queen," small sterile females or "workers," and medium-sized males or partially sterile females called "drones." They differ also in that their larvæ, instead of being sealed up in a cell along with a store of food, are subject to unremitting care and attention.

The best known of all these social insects are undoubtedly the semi-domesticated Honey Bees, Apis mellifica. They are considered to be the most highly developed of the Anthophila. In point of interest no insects surpass and few equal them. Publishers, however, even the most lenient, set a limit on an author's verbosity, and the Honey Bee does not lack its literary champions of every degree; its merits have been sung in verse and lauded in prose. A fair-sized library could be filled with works dealing with this industrious insect; on that account we perforce omit it from our pages.

Bombus, the genus of Bumble or Humble Bees, has more than a dozen British representatives. The nesting habits of the species fall naturally into two classes; for some are subterranean nest-builders, others nest on the ground. They all differ from Social Bees of the genus Apis in that their workers are merely imperfect females, whereas those of the latter genus are struc- 
turally different from either males or females. Again, each colony ends with the year; a few hibernating females begin new colonies in the spring.

Of the subterranean nesting Bumble Bees, our commonest species are the Earth Bumble Bee, Bombus terrestris, and the Stone Bumble Bee, B. lapidarius. The former is hairy, with a yellowish-grey tip to its abdomen and a yellow band across its thorax and fore-part of its abdomen; the latter is a big black hairy insect with a red-tipped abdomen; the males are distinguished by a yellow band just behind the head.

The nesting habits of the two species are practically identical. In early spring a hibernating female becomes active, and seeks a nesting-place. Usually a deserted mouse-hole or some hollow in the ground is selected. Moss is then gathered and stored in the hole, and under this moss a cell is placed, formed of wax externally and honey-saturated pollen internally; several eggs are deposited in the cell before it is closed. Other cells containing more eggs are added at intervals. Then the larvæ in the first-formed cell hatch; the mother punctures the cap of the cell, and feeds them with regurgitated food. Later the larvæ spin silken cocoons within their cells, and emerge at irregular intervals. The first of the new colony to appear are always small females, known as "workers." The "queen" now becomes little more than an egg-laying machine; she rarely leaves her nest, and often loses the power of flight. The workers build more and more cells, which the "queen" supplies with eggs; there is no food-store in these later cells, the larvæ being fed solely by the workers. Stores of pollen and honey are laid up, 
however, in the discarded cells which the earlier members of the community have vacated. Some of the later females are fertile and capable of laying eggs, whilst towards the end of the summer the "drones" or males appear, and mate with the females destined to hibernate through the winter and become the future queens.

Some of these underground nests contain as many as four hundred individuals, poor architects all, but very industrious workers, being on the wing at three o'clock or so in the morning. It is stated, and the statement has frequently been confirmed, that each nest harbours a trumpeter whose duty it is to arouse the inmates when the hour arrives for their day's work to commence.

Of the ground-nesters there are also two very common species, the Moss-Carding Bee, B. agrorum, and its near relative $B$. venustus, also a Carder. The former may be recognized by its tawny thorax and black abdomen, and the latter is wholly tawny. The cells are placed in a hollow in the ground, and after they are constructed the mother Bee drags moss to the site, shreds it with her mandibles, and scatters it over her cells, till they are covered, with her hind-legs.

Bombi have their " cuckoos" like many other Bees; they belong to the genus Psithyrus, and, except for their larger size, very closely resemble their hosts. They collect no pollen or honey--in fact, they are not adapted for so doing. They are, however, not quite such arrant rogues as some of the "cuckoos," for they actually construct their own cells alongside those of their hosts, but they leave the duty of rearing their young to the worker Bombi. Towards the end of the season these 


\section{WASPS}

" cuckoos" remain within the host nest and assiduously devour the stored honey. However similar host and " cuckoos" may be in all other respects, there is one infallible method of determining which is which. All species of Bombus have clear, unclouded wings; all Psithyrus species have smoky wings-the latter, moreover, have no pollen-collecting apparatus.

The nests of these surface Bees have far fewer inmates than the subterranean species. From a hundred to a hundred and fifty is a fair average-in fact, the latter figure is above the average.

\section{DIVISION 2. DIPLOPTERA, OR WASPS.}

The Diploptera are so named from the habit of its members of folding their front wings longitudinally when at rest. The division is split up into two families, the Eumenidce and the Vespidoe; the former are Solitary, the latter Social.

EUMENIDж.-Tarsal claws toothed; outer face of mandibles longitudinally furrowed.

In Britain there are sixteen species of this family, one belonging to the genus Eumenes and fifteen to the genus Odynerus.

Eumenes coarctata is a long-waisted, yellow and black insect. It builds its globular mud nests on the twigs of some shrub, usually heather, and stores them with small Lepidopterous larvæ. In each nest it lays a single egg. Internally the mud nest is divided unequally into two parts; in the larger division the Eumenes larva lives and grows, in the smaller it deposits its excrement and wasted food material.

Fabre has described the very interesting nesting 
habits of $E$. pomiformis, which, by the way, except for the design of the nest, are very similar to those of Odynerus reniformis. The nest is vase-like and made of earth; in its walls small stones are embedded. The interior consists of a single chamber, which the mother Wasp stores with fifteen or sixteen partially paralyzed Caterpillars. Now, the Eumenes egg and larva are delicate, and the wriggling Caterpillars would speedily bring about their destruction. The Wasp is equal to the occasion, for it suspends its single egg by a fine silken thread to the roof of its nest; here egg and larva are out of harm's way. When the larva emerges it can just reach its living food from its suspended position. As it grows older, by a marvellous provision of Nature, the egg-shell unfolds as a kind of ribbon, so that the larva clinging to it can reach food farther away. By the time the larva can no longer reach more food from above, it has grown big and strong enough to descend amongst the remaining Caterpillars without suffering any harm.

Odynerus is a genus of insects very similar in appearance, but with very varied nesting habits. For the most part they seek out holes and crevices already made. O. callosus nests in clay banks; $O$. spinipes has similar habits, but builds a curved, downwardly projecting spout at the entrance. Other species favour door-locks, cotton-reels, disused screw-holes, and the like, and some nest in plant-stems, lining the interior with fine sand. Chrysidice are the "cuckoos" of Odynerus.

The Australian genus Abispa constructs immense nests with funnel-shaped entrances. 
Species of the genus Rhynchium, for the most part, nest in the pithy stems of plants. Some species, however, build mud nests after the manner of Eumenes, and $R$. brunneum is said to "obliterate hieroglyphic inscriptions in Egypt by its habit of building mud nests amongst them."

VESPID E.-Claws not toothed, mandibles not furrowed.

There are eight British species of Vespidce, and they build three distinct types of nests, or, to be more correct, they frequent three different situations. Vespa vulgaris, $V$.rufa, and V.germanica, nest underground; V. arborea, $V$. sylvestris, and $V$. norvegica, build suspended aerial nests, and $V$. crabro seeks an intermediate site such as a hollow tree or beneath a thatched roof. Our eighth species, V. austriaca, is rare.

All the Social Wasps build elaborate though shortlived nests, and the early building is always carried out by a single queen. The material for the comb is all of vegetable origin, which is gathered in the mandibles of the nest-builders, made into pulp, and cemented with a secretion of the Wasps. "Nearly any oak fence in the open country bears upon it during the summertime hundreds of marks as if it had been lightly scraped with the finger-nail; these marks are made by the jaws of wasps." The early "queen "-made cells are of finer material than those formed later by the workers. The queen cements a single egg to the upper angle of each of the early cells, and in about a week the larvæ emerge. As the Wasp cells are open and inverted, the legless grub keeps some of its hinder segments within the remains of the egg-shell, so that it may not 
fall out. In common with all other Wasps, as opposed to Bees, the larvæ are fed upon animal matter in the shape of Green Flies, etc. As growth takes place the cells are added to by the queen. When fully fed the larvæ spin a silken cocoon within their shell, and later the perfect Wasp appears. Her first act is to clean herself, and then to visit a well-grown larva, from whose mouth she obtains a drop of liquid food. Her early duties consist in helping the queen to feed the other larvæ, but in a day or two she becomes a worker, and sallies forth to hunt for food for the inmates of the nest, or helps to build more cells and thereby enlarge her home. Often there are many thousands of inmates in a Wasp's nest; as many as twelve thousand have been counted at one time, and during a single summer one nest may harbour sixty thousand individuals" workers," "drones," and "queen."

In the nests of our common Wasps there are several guests. The little Fly, Pegomyia inanis, which lays its eggs on the comb, is a useful member of the community. Its larvæ devour the Wasp excrement which always collects below the comb. The larvæ of another Fly, Volucella sp., visit each cell in turn and feed upon the excrement of the Wasp larvæ. The Beetle Rhipiphorus paradoxus is a parasite. "The larva of this beetle is believed to leap upon the bodies of worker wasps when they are gathering woodfibre off the surface of timber. It is thus carried by the returning insects into their nest. It now eats its way into a wasp grub and devours the less important tissues of its host; when it becomes of such a size as to threaten the life of its unfortunate victim, it passes out through the skin of 
the wasp grub, plugging the wound with the skin which it itself moults as it issues, and now becomes an external parasite upon the same host. It refrains from killing the wasp grub till the latter has spun its cocoon. Eventually the beetle larva completely devours the wasp grub, and accomplishes its own metamorphosis within the cocoon provided for it by its prey."

The genus Polistes is mainly remarkable for the wonderful colour variations exhibited even by different individuals from the same nest.

Polybia species build neat little pear or apple-shaped nests, and suspend them from the branches of trees or shrubs; each nest is enveloped in Wasp paper, and has one or two more holes for the going and coming of the inmates. Some of these nests are ornamented externally.

Chartergus chartarius makes its Wasp paper so solid and compact that it has the appearance of stone. Apoica pallida covers its nest with a specially fine paper skin.

Division 3. Fossores, or Digger Wasps.

All the Fossorial Wasps are carnivorous, all are solitary, and most of them display such remarkable instinct in their hunting, their nesting, and their provision for the future, that, by their actions, they have drawn to themselves a host of observers and enthusiasts who have made of them a lifelong study. Lest the budding entomologist, on that account, should decide to direct his studies in another channel, we can assure him that much remains to be learned, and no class of insects will better repay the time that is given to their study. 
The Fossores are sun-lovers, more so even than Butterflies; dry, sandy districts are the favoured haunts of most species, but, naturally, their habits vary-in fact, Sharp places them, according to their habits, in four groups: Parasitic or semi-parasitic species which usurp the nests of other insects; the potters-builders of earthen cells; ground burrowers; and wood-tunnellers. All the work of tunnelling, building, or burrowing is carried out by the females; their mates take but little part in domestic affairs.

Mutilumds.-Females wingless and without ocelli; males winged, ocelli present; tibiæ spined; antennæ thread-like.

These insects are often called Cow or Solitary Ants. As is so often the case, both names are inappropriate, for the Mutillids are not Ants. All of them are clothed with a vestment of hair, and there is a standard colour scheme of deep red and black, relieved by white spots which is common to the females of the majority of species.

The males are always totally unlike the females; they are winged, active creatures, whereas the females are apterous and sluggish-an uncommon event amongst the Fossores, whose females are usually exceedingly active.

But little is known of the habits of these insects. The commonest European species, Mutilla europaca, appears to frequent the nests of Bumble Bees, especially those of Bombus agrorum and $B$. variabilis. It is probable that the Mutillid larvæ are parasitic on the Bee larvæ, and that the females feed upon the store of honey. The winged males leave the Bombus nests 
immediately they emerge. There are three rare British species.

ThynnIDж.-Females wingless, stout, and thorax divided into three unequal parts; males winged, slender; legs spinous.

By some authorities these insects are not separated from the Mutillido. Most of them are black in colour with some yellow markings. Little is known of their habits, but they are believed to be parasitic on Lepidopterous larvæ. The males are so totally unlike the females that in many cases they have been described as different species. The sole British representative of the family, Methoca ichneumonides, is exceedingly rare.

SCOLIID $2 .-A n t e n n æ$ stout and short; legs stout with compressed and swollen femora and heavily spined tibiæ; apical area of wings devoid of nervures.

Many of the Scolias are large, powerful insects; most of them are hairy and of a black colour relieved with yellow or red spots and bands. For the most part, males and females are strong on the wing, but there is a curious Central Asian species, Komarovia victoriosa, in which the female has minute wings, useless for flight.

With few exceptions, these insects are parasitic upon the larvæ of Lamellicorn Beetles. Fabre has investigated the habits of Scolia bifasciata, which oviposits on Cetoniid larvæ, and of $S$. interrupta, a parasite of Melolonthid larvæ. These larvæ dwell below ground, and it is necessary for the mother Scolia to burrow in order to find her prey. Having done so, she paralyzes it by stinging a particular nerve ganglion on the ventral surface of the larva. This ganglion controls the body movements of the victim, and the Scolia never stings 
till she is able to reach exactly the right spot. Having rendered her victim inert, she deposits a single egg just behind the fore-legs. When the parasite larva hatches, it at once buries its head in the skin of its host and feeds on the non-vital parts. Host and parasite never part company till there is nothing left of the former but an empty skin.

Elis 4-notata is said to depart from the usual Scoliid custom by preying upon Spiders, and still more curious is the story of S. atrata as related by Kirby. This West Indian insect is black, and its reddish wings are tipped with violet. "It is in the habit of provisioning its nest with a large grasshopper. It first digs its nest, and then goes in search of a grasshopper. Having partially disabled it with its sting, it mounts on its back and rides it up to its own grave, where it buries it. If the grave proves to be too small the wasp drives the grasshopper away while it enlarges it as much as is required, and then brings it back to the hole."

There are but two British Scoliids belonging to the genus Tiphia-small black insects with red-brown legs. SAPHYGID瓜.-Closely allied to the Scoliidoe; antennæ as long as the head and thorax and slender; legs slender, not spined; males and females winged. A family of which little is known, and that little is open to doubt.

We have two British species, Sapyga 5-punctata, with black males marked with five transverse white spots on the abdomen; the markings of the females are similar, but their abdomens are red. S. clavicornis, our second native species, is black with yellow markings. The former species is said by Fabre to live in the nests of 
Osmia and to feed upon the stored honey, whilst Smith states that it preys upon Caterpillars.

Psammocharide (till recently known as Pompilida). -Pronotum reaches the tegulæ laterally; hind-legs long; eyes elliptic; abdomen oval, attached to the thorax by a short petiole.

The Pompilids include some of the largest, most active of the aculeate Hymenoptera. Their long hindlegs indicate the fact that they are probably fleet of foot, and this is the case. They may often be observed running hither and thither over the ground in search of prey.

Many species of aculeate Hymenoptera, although possessed of stings, are either incapable of piercing the human skin, or at worst they cause a wound which is of temporary duration. The larger Pompilids, some of them three inches in length, are creatures to be dreaded, and a sting from one of them may have really serious consequences.

As a family these insects are remarkably uniform in colouring. Rich black with red legs, and sometimes antennæ and wings of beautiful iridescent blue and green sheen, is a general description which applies to many species, especially of the genus Pepsis.

In Britain we have thirty species, half of which belong to the genus Pompilus. As a rule, these insects are diggers, using their large approximated coxæ to shovel the earth from their burrows, a fact which they accomplish by coming from their excavations backwards. Having brought the earth to the surface, it is scattered far and wide by their long hind-feet. Certain species, amongst them the British Agenia carbonaria, depart 
from the usual custom and construct vase-shaped mud cells, which they store with insect food for their larvæ.

An Australian species, Priocnemis bicolor, appears to be a vegetable-feeder-in part, at any rate. This insect seeks a Cicada in the act of sucking sap from a hole which it has punctured in a tree. "The Priocnemis has not the art of making the puncture necessary to procure sap, so the wasp seizes the Cicada and shakes it till it leaves its hold and flies away, when the Priocnemis takes its place and sips the sap. The wasp never hurts the Cicada."

With few exceptions, all the Psammocharidce prey upon Spiders, and each species appears to have a special species of Spider prey. Now, Spiders are by no means defenceless creatures, and the Wasps often display considerable ingenuity in their efforts to get the better of their victims. Certain species of Pepsis prey upon the enormous Tarantulas, and the battles between Wasp and Spider do not always terminate in favour of the former.

According to Latter, these Wasps are in the habit of training for their encounters. "Frequently two females -note this is no love-dance, for both are femalesmay be seen to settle down face to face on a patch of sand, to move round and round as though searching for an opportunity to lean over first on one and then on the other side, and from time to time to lash round with their wonderfully flexible abdomens, as though delivering a stab from the venomous sting. In their actual encounters with spiders it behoves them ever to face the enemy, for the poison fangs of the spider are situated at the head end, and it is thus from that quarter 
that danger threatens." The females to which reference is made are of Pompilus viaticus, one of our largest native species, which, with $P$. rufipes, is common on inland sandy ground. By the coast one may find and observe the habits of another common species, $P$. plumbeus, whose special prey is the Spider Lycosa picta.

All the Psammocharidoe are characterized by a wonderful solicitude for progeny they will never see and " an acute memory for localities." Their actions "seem to point to an intelligence higher than mere instinct; the insects adapt their conduct to meet various contingencies; they appear to have a definite purpose in view, and that purpose they achieve in a fashion which makes it difficult to deny them at least some glimmering of the reasoning faculty." Fabre has written of these insects, and every entomologist should read his works. The bearing away by the Wasps of Spiders heavier than themselves, the battles with their prey and their overcoming by stealth, the hiding of their burrows that others may not plunder their stores are all related as only Fabre can tell them.

SPHEGID A.-Prothorax narrow in front and not produced backwards to the base of the wings; first and sometimes part of the second abdominal segments forming a petiole; wings short.

This is by far the largest family of Fossores, and is usually divided into ten subfamilies. In Britain we have at least ninety species. As with the preceding family, many of the Sphegids and their doings are charmingly described by Fabre, and, risking repetition, we would say again, Read him.

SPHEGIDES.-The Sphegides are, for the most part, 
parasitic upon Locustida; a few of them prey upon Spiders and some upon Caterpillars.

The common habit of the genus Sphex is to construct a horizontal burrow about three inches in length; this is continued into a vertical burrow of about the same length, terminated by an oval chamber. The horizontal tunnel forms a shelter and resting-place for the insect; the oval chamber is a nursery for its larva. As soon as the terminal chamber is completed, an Orthopteron is caught, paralyzed, and brought therein and an egg deposited thereon. The chamber is then closed, and a second, third, and even a fourth, are made and similarly stocked. Then the insect starts a new burrow, till it has completed ten such structures; and as its period of activity extends but a month, it is obvious that the female Sphex labours with unceasing energy. The larvæ feed upon the stored Orthoptera and pupate within the subterranean cell. Their cocoons are interesting in that they consist of three layers, the inner one being waterproof, to prevent damage to the pupa from the damp earth.

There are four species of Ammophila, or sand-lovers, in Britain. They are easily recognized by their elongate red and black bodies. They are burrowers, but they do not use their coxæ for removing the earth from their excavations, after the manner of the Pompilids. All their tunnelling is carried out by their powerful mandibles; the soil is loosened by these organs, and in them carried to the surface.

Our largest species is Ammophila sabulosa; its larvæ are nourished upon Caterpillars, two evidently being the normal supply for one larva. After collecting her 
small store and laying an egg upon one individual, this species covers the mouth of its burrow and leaves its progeny to its fate. The equally common $A$. campestris, however, does not provide all the larval food at one time, but returns now and again with fresh supplies of Caterpillars for its growing family.

The genus Sceliphron, not unlike the Ammophilas in form, but distinctively banded with yellow and black, possess the curious habit of selecting human habitations for their nesting sites. They build mud cells and store them with Spiders. A South European species, S. spirifex, selects a spot in an open fireplace; the Australian S. loetus attaches its cells to some article of furniture and decorates them with acacia bark. The Indian S. madraspatanus, which, by the way, feeds its larvæ on Caterpillars and not on Spiders, decorates its nest in a peculiar manner with rays of mud, "exactly imitating a lump of mud thrown with some force."

Ampulicides.-Closely allied to Sphegides, but all the species have elongated heads and necks, and the petiole is articulated with the thorax ventrally.

This is a small but widely distributed subfamily. Many of the species are of gorgeous metallic green or blue colour. They have been studied but little; so far as is known, they prey upon Blattidoe.

BemBecIDEs.- Very Wasp-like insects, being for the most part black banded with yellow; their bands are always broken in the middle line, and this alone, apart from other more technical characters, at once distinguishes them from the Wasps.

Most species-there are none in Britain-prey upon Diptera. They build their nests in loose soil, and they 
feed their larvæ upon Flies which they bring to their nests from time to time. A North American species, Sphecius speciosus, provisions its nest with a paralyzed Cicada. As the Cicada is twice the size of its captor, the latter climbs with its prey to some high elevation before returning to its nest. With this advantage it is able to plane downwards to its destination without undue effort.

Phinanthides.-Head wider than thorax; intermediate tibiæ apically armed with one spur; anterior tarsi ciliated.

Wasp-like insects, usually of a black and yellow colour. The genus Cerceris preys upon Beetles, and is remarkable for the fact that each Cerceris species preys only upon a certain family of Beetles. Even though the victims be of varied form and colour, these Wasps are never misled as to their prey.

Our common British Cerceris arenaria preys upon Weevils; another of our native species, $C$. labiata, appears to select the "Flea" Beetle Haltica tabida; whilst $C$. bupresticida, as may be guessed from its name, confines its attention to the Buprestida.

Certain species prey upon Bees of the genus Halictus, and Philanthus triangulum is an enemy of the Honey Bee. After having killed its victim, the Wasp so kneads the Bee as to force the honey from its honey sac, and the sweet liquid is greedily imbibed. The Bee is then carried off to the Philanthus nest, a long, deep tunnel in the ground, and an egg is deposited upon its dead body.

MIMESIDES.-Minute insects with petiolate abdomens; middle tibiæ armed with a single spur. 
These are minute insects which make their nests in hollow stems or in disused galls. Psen concolor preys upon Psyllidor. Our British Pemphredon lugubris bores into the decayed wood of beech-trees and stores its nest with Aphidce. Cemonus unicolor takes possession of an old Cynips gall for its home, or the late dwelling of the gall-forming Fly Lipara lucens on the stem of the common reed.

Crabronides.--Large, square head; prothorax short; antennæ often thickened at the apex; hind-tibiæ frequently thickened; clypeus hairy.

This is by far the largest subfamily of Sphegidce as far as Britain is concerned; there are at least thirty native species.

We have mentioned that the hind-tibiæ of these Wasps are frequently thickened; even in the British Crabros there are many species with curiously formed legs. Crabro tibialis exhibits swollen tibiæ to a remarkable degree; $C$. gonager has swollen front tibiæ; and for the rest, the legs of $C$. cribrarius, C. peltarius, C. scutellatus, C. clypeatus, C. interruptus, C. cetratus, and $C$. palmarius, will all repay investigation. The uses of these extraordinary modifications have never been explained; but, as they occur only in the males, they are probably secondary sexual characters.

The Crabros prey upon Flies. C. leucostomus preys upon the metallic green Chrysomyia polita; C. podagricus upon Gnats; C. dimidiatus upon Bluebottles. Their nesting habits vary. C. quadrimaculatus bores a nest in decayed wood; $C$. wesmaeli and $C$. cribrarius burrow in sandy soil. The adult Wasps imbibe the nectar from various flowers, a habit which is shared by species 
of the genus Oxybelus. This genus also preys upon Diptera, and one species at least, $O$. uniglumis, forms an excellent example of " aggressive mimicry," for it closely resembles its prey. Dark grey with a whitespotted abdomen, this Wasp as it basks in the sun might easily be mistaken for a House-fly. The female makes a short burrow in the soil and stocks it with nearly a score of Flies, which she catches on the wing after the manner of a hawk, and amongst which she deposits a single egg.

\section{Division 4. Formicide, oR ANTS.}

The most distinctive feature of all Ants is the mobile articulation between the thorax and the main portion of the abdomen. Another feature which cannot fail to strike the student is the extraordinary degree of polymorphism which occurs among these insects, but of this we have spoken elsewhere (p. 30). Some forms are blind: this is never the case with winged forms; others have well-developed eyes and ocelli. Their heads are of variable proportions: in the forms of certain species they can justly be described as minute; other forms have heads apparently out of all proportion to their bodies.

From a bionomical point of view no insects surpass the Ants in interest. Many of them are long-lived, so at least they may learn by experience; as a class they have brought the art of living together in a perfect social community to a very high state. They possess one qualification which is not equalled in any human community: each individual works for the good of its colony, never for the benefit of self. "There can, 


\section{ANTS}

indeed, be little doubt that Ants are really not only the ' highest ' structurally or mechanically of all insects, but also the most efficient." To deal but cursorily with these remarkably interesting insects would require a volume larger than "Insect Life." Professor Wheeler has written an absorbingly interesting book on Ants; it should be read by those who would learn more of Ants than we can tell.

CAMPonotides.-Constriction of the abdomen with a single protuberance (node); no true sting; cloacal opening circular.

This is a large subfamily, and contains some of the most interesting species. None of them can sting, but they are able to eject a highly acid fluid to a considerable distance, a habit which renders them formidable propositions for other animals to attack.

By far the largest genus is Camponotus, but it does not contain any exceptionally interesting species and no British representatives. C. ligniperdus is the largest European species, and the allied American Carpenter Ant, C. pennsylvanicus, whose nests are built in treestumps, has been so minutely described by McCook, in his "Notes on the Architecture and Habits of the Pennsylvania Carpenter Ant," that readers who are interested will naturally turn to this account for fuller information.

Even a superficial study of Formicidae will reveal wonder upon wonder to the student, and amongst such extraordinary insects as Ants it is difficult to know where to award the palm for ingenuity. Assuredly the Indian Tree Ant, CEcophylla smaragdina, ranks with the most ingenious, and its doings were for years doubted 
by sober, or shall we say sane, scientists, till eye-witnesses of undoubted integrity testified to the truth of the earlier reports. In appearance the insect is remarkable, for it is green-the usual Ant colour is brown, black, or red. As Ecophylla lives in trees and nests amongst the leaves, its green colour is protective. It is, however, in its nesting habits that this insect is so extraordinary. Selecting several leaves growing in proximity to one another, their edges are brought together and fastened with silk, so that the whole forms a commodious abode for the Ant colony. These nests, which were discovered long before anyone had seen them in the process of construction, gave rise to much wonderment, for no Ant possessed spinnerets or had the power of forming silk. At length the mystery was solved, though the earlier reports were not believed. Nest-making was carried out by a band of Ants working together; having found a group of leaves suited to their purpose, hundreds of workers seized the edges and dragged them together-a feat beyond the powers of a single Ant, or even of a dozen individuals, was accomplished, after much labour, by hundreds. Next came the most astounding part of the whole performance. When the leaf-edges were drawn together, a second host of Ants appeared, each bearing a larva in its mandibles. These Ants used the larvæ as shuttles, applying them, now to one leaf-edge, now to another, and squeezing them gently the while, so that they might give forth the silk which, in normal circumstances would have gone to the making of their cocoons. By this marvellous means the leaf-edges were bound together and the new nest completed. 
Equally interesting are the American Honey Ants, Myrmecocystus melliger and $M$. hortideorum. These creatures are provident, and they lay up stores for the inevitable rainy day. Other Ants do likewise, it is true, but none in such a curious manner as the Honey Ants. They live underground, and their nests are always constructed in the neighbourhood of the sheoak, a shrub which bears honey-secreting galls. In the nests a large chamber is constructed, and on its domed roof many individuals hang, suspended upside down, all their lives. By night the workers sally forth to steal the sweet fluid from the she-oak; on their return to the nest they feed the hungry individuals who have remained behind, and the surplus is regurgitated and fed to the individuals suspended from the roof of the larder. The operation is repeated time and again, till the honey-storing individuals become distended out of all proportion-their honey-crops attain the size of a small cherry. When the outside food-supply fails, these living honey-pots yield up their stores to their fellow-Ants, and thus enable the colony to survive periods of stress. Similar habits have been observed in a South African Ant of the genus Plagiolepis and in the Australian Melophorus inflatus.

The genus Polyrachis contains species of remarkable form and habits. In form they are conspicuous in possessing a number of formidable-looking spines on various parts of their bodies; in habit they are peculiar in that they only form small colonies, sometimes as few as a queen and a dozen workers.

The nests of many species are constructed on or within leaves. $P$. argentea, a beautiful Ant covered 
with silvery pubescence, builds a small nest of vegetable material on some broad tropical leaf; $P$. rastella hides its nest between two leaves; $P$. mayri and $P$. nidificans construct minute paper-like nests on leaf-surfaces.

Of the British Campanotides, the most interesting are Formica rufa and $F$. sanguinea. The former, variously known as the Wood Ant, Hill Ant, and Red Ant, lives for the most part in pine-woods. It forms a striking contrast to the genus Polyrachis, for its communities are formed of innumerable individuals. Its nest consists of a mound of vegetable matter, and frequently of large proportions. The mound is tunnelled by numerous galleries, leading to further galleries in the soil. The Wood Ant is one of the many species partial to Aphides, who supply it with sweet honey-dew. The most remarkable fact, however, concerning this insect is the enormous variety of guests which find a home in its nest. It has been estimated that any one of no fewer than fifty distinct kinds of guests may be met with in the Wood Ant's spacious nest.

F. sanguinea, the Blood-Red Slave-making Ant, has been described as the most sagacious and the most courageous of all Ants. Whether it deserves these encomiums is another matter. Although a slavemaker, it is by no means dependent upon slaves, and can well exist without them. Its nests are made in banks, and harbour vast communities. From time to time the warriors sally forth and plunder the nests of F. fusca, F. cunicularia, and Lasius flavus, bearing off the pupæ to its own abode. When the pupæ hatch, the aliens faithfully serve their owners and carry out most of the duties of the community, for sanguinea is 
by nature lazy and has little stomach for anything but fighting and robbing his neighbours.

The most notorious slave-maker, however, is the Amazon Ant, Polyergus rufescens, a European but nonBritish species. This Ant is made for fighting; its mandibles are designed for gripping its enemies to their undoing, and so unfitted are they for any other purpose that their owners cannot even feed themselves. To their slaves these Ants must look for every particle of food. F. fusca and its allied race, F. fusca auricularia, are mainly the individuals whose lot it is to be slaves of the Amazon Ant.

The most numerous British genus of the Campanotides is Lasius, and the commonest species are $L$. flavus, the Yellow Meadow Ant; $L$. niger, the Black Garden Ant; and L. fuliginosus, the Jet Black Ant.

The Yellow Meadow Ant and the Black Garden Ant are subterranean dwellers. They both form underground tunnels and galleries of a complex nature; in them they have nurseries, larders, and all the other chambers usual in an Ant community. The Garden Ant is one of the most assiduous guardians of Aphides, from which it obtains a sugary fluid known as honeydew. Not only does this species frequent the haunts of Aphides, but it tends the subterranean forms as carefully as any farmer tends his cows. "Many Aphida exhibit the phenomenon known as alternation of generations-that is, there is a winged sexual brood and a wingless asexual brood; and sometimes the former lives in the open air and the latter at the roots of plants. When, therefore, these ants meet with a winged Aphis about to lay eggs which will produce a 
subterranean brood, they first clip her wings to prevent her escape, and then open a way for her, and guide her down to the roots of the grass. But when winged Aphidce are born in their nests, they do not clip their wings, but open a way for them into the air, that they may fly to the plants on which their young are to feed, and thus insure the perpetuation of the species." This statement brings us up against an important point in Ant economy. Though few species of Ants can be termed harmful to agriculture in themselves, many species, by their pernicious and wonderfully successful habits of cultivating Aphides, Coccidce, and other noxious insects, are indirectly responsible for considerable damage. In no case is this better exemplified than in the Argentine Ant, Iridomyrmex humilis, which actually constructs shelters for harmful Scale insects, to protect them from the elements, and transports them from plant to plant as the needs of their appetites dictate.

Dolichoderides.-Similar to Campanotides, but all species possess a rudimentary sting.

This is a small and little-known subfamily with but a single British representative, Tapinoma erraticum. This insect is carnivorous in its tastes, and, according to Forel, earns its living by stealth. It attends the combats of other Ants, and, after the encounter, seizes the corpse of the vanquished for a meal. Should the need arise for Tapinoma to defend itself it does so by touching its opponent with the tip of its mobile abdomen and simultaneously ejecting a noxious fluid.

A European species, Liometopum microcephalum, is more courageous than its British relative A minute 
insect, it lives in huge colonies in the disused burrows of wood-loving Beetles, and attacks other Ant colonies with hosts so countless as to bring about their discomfiture.

Myrmicides.-Constriction of abdomen with two protuberances (nodes); sting present in most species.

Belonging to this subfamily are various species of the greatest biological interest: dwellers in the homes of other Ants, and whose males or females are either aberrant or unknown. Space forbids the description of these Ants. We may mention, however, the British Formicoxenus nitidulus, which occurs in the nests of Formica rufa; and Anergates atratulus, a guest of Tetramorium caspitum. For details of these species the reader is referred to Wheeler's " Ants."

Our commonest British species of the Myrmicides are the native Myrmica rubra and the introduced Monomorium pharaonis Neither of them is of particular interest, but the latter is a household insect which sometimes swarms in hordes upon human food, especially sugary food.

Among the most interesting of the subfamily are the Harvesting Ants, Aphanogaster structor and A.barbarus, of Southern Europe; A. arenarius of Northern Africa, and Pogonomyrmex barbatus of North America. These Ants possess the uncommon habit of storing their nests with seeds of various kinds, and the last-named species removes the husks from the seeds and stores them on a special heap outside the nest, a proceeding that has given rise to the erroneous report that these Ants plant gardens outside their nests. Some seeds are probably dropped by the Ants, some are carried out with the 
husks, but that there is any attempt to sow the seeds has never been shown-in fact, all the efforts of these Ants are designed to prevent the sprouting of the seed taken into their nests; this they do by biting off the young roots as soon as they appear.

Cremastogaster is a curious genus in that the insects can invert their abdomens over their heads, and thus assume an attitude more fearsome than dangerous, for they possess feeble stings.

The genus Atta contains the most injurious and some of the most remarkable species of a remarkable family. They are known as Leaf-Cutting or as F'ungus Ants. For the most part they are tropical insects, of large size, dwelling in enormous colonies. They build subterranean nests, and sally forth to do damage to the neighbouring vegetation. This they do so effectively that in some parts of the world all idea of cultivation has been abandoned. Climbing the trees in their thousands, the workers cut pieces of leaf about the size of a threepenny-piece and return with them to their nests. After a raid of this description, many trees in the neighbourhood of an Atta colony are defoliated. The leaves, when removed to the nests, are cut up, rolled into balls, and form the medium on which a fungus, Rozites gongylophora, grows. This fungus is most carefully tended, and forms the food of the colony; the spores from which the growth arises are brought to the nest, in the first place, by the queen-mother. The story of the Fungus-Growing Ants forms one of the romances of entomology.

Pseudomyrma bicolor, a South American Ant of attenuated form, has a curious habitat. It dwells in 
the thorns of the bull's-horn acacia, which it enters by boring a neat round hole near the base. Its food is supplied by the plant in the form of honey secreted by glands on the leaves. In return for its food and lodging this Ant, which is armed with a formidable sting, drives away Attas and other insects with designs on the leaves of the acacia.

Ponerides.-Constriction of abdomen with one protuberance (node); abdomen elongated; well-developed sting.

This is a large subfamily of which we possess but little reliable information. It includes the Australian Bull-Dog Ants, Myrmecia, armed with well-developed, powerful mandibles, and with stings capable of inflicting serious wounds.

The two British species, Ponera contracta and $P$. punctatissima, are of but little interest.

DORYLIDES.-Constriction of the abdomen imperfect; abdomen elongate and cylindrical; antennæ inserted near the front margin of the head.

These Ants are remarkable for the great differences in form between the females and the workers, and for the non-Ant-like appearance of the males. Another striking feature of the Dorylides is that they are nomadic; they build no permanent nests, but wander from place to place, a habit the more extraordinary when we learn that the females and workers are blind.

Of these Ants, the genus Echiton is confined to the New World, the genus Dorylus to the Old. There is, needless to say, considerable confusion with regard to the systematic position of many members of the Dorylides. As Sharp remarks, fifty or sixty years of 
research has only produced as many females as may be counted on the fingers of one hand.

So far as is known, the Driver Ants all have similar habits, wandering from place to place in search of food, and finding temporary shelter in hollow trees or the nests of other Ants. According to Belt, "They make their temporary habitations in hollow trees and sometimes underneath large fallen trunks that offer suitable hollows. A nest that I came across in the latter situation was open at one side. The ants were clustered together in a dense mass, like a great swarm of bees, hanging from the roof, but reaching to the ground below. Their innumerable long legs looked like brown threads binding together the mass, which must have been at least a cubic yard in bulk, and contained hundreds of thousands of individuals, although many columns were outside, some bringing in the pupæ of ants, others the legs and dissected bodies of various insects. I was surprised to see in this living nest tubular passages leading down to the centre of the mass, kept open, just as if it had been formed of inorganic materials. Down these holes the ants who were bringing in booty passed with their prey. I thrust a long stick down to the centre of the cluster, and brought out clinging to it many ants holding larvæ and pupæ." 


\section{CHAPTER VIII \\ SIPHONAPTERA AND DIPTERA}

ORDER SIPHONAPTERA, OR FLEAS.

Pulicidz.-Wingless insects, laterally compressed. The separation of head from body not conspicuous. Antennæ short and thick in depressions behind and above the eyes; metamorphosis complete.

By some authorities these too familiar, blood-sucking insects are placed in three families:

(i.) Sarcopsyllidoe-the Chigoes.

(ii.) Pulicida-true Fleas.

(iii.) Ceratopsyllidoe-Bat Fleas.

The general structure of the common Flea is too well known to need any description. Its hard chitinous covering is proof against all but the most severe squeeze; its powers of leaping are proverbial. "If man had the leaping powers of some fleas, they would bound with ease backwards and forwards over the cross on the top of St. Paul's Cathedral." What is not so well known is the fact that nearly fifty different species of Flea are known in Britain.

The Flea peculiar to man is Pulex irritans, but other Fleas, notably the Cat Flea, Ctenocephalus felis, Bouché, and the Dog Flea, C. canis, Curt., are by no means averse to a meal of human blood. 
The human Flea lays her eggs, a few at a time, in the dusty corners of houses, and in a few days the larvæ emerge. They are white and thread-like, and are furnished on their heads with a thin, knife-edged plate, which serves as an egg-opener. By rubbing the cutting edge against the egg-shell, the larvæ split the walls of their temporary prison. The legless larvæ moult several times during their short existence, feeding the while on decayed organic matter. When fully fed they spin cocoons, and after the lapse of a few more days the adult emerges.

Certain Fleas appear to confine themselves to definite species of hosts, others are more catholic in their tastes. A study of the distribution of these parasites on their varied hosts is highly instructive: certain very closely related animals harbour different Flea species; other unrelated animals are hosts for the same species of parasite.

The anatomical structure of Fleas affords most interesting study. They are beautifully adapted for crawling through the furry coats of their hosts. The combs, toothed structures which occur on the heads of these insects, are used as additional aids in holding the host fur, and analogous structures are found on certain parasitic Flies and Beetles.

All the Bat Fleas are blind, so also is the common Mouse Flea, Leptopsylla musculi, Duges. In these blind Fleas a spine often takes the place of the eye.

The antennæ of Fleas are also well adapted to their mode of life. They fit into grooves at the side of the insect's head, so that when the Flea is crawling through 
closely growing hair its antennæ do not impede its progress.

More truly parasitic than our common Flea is the Chigoe, Dermatophilus penetrans of South America. The female of this species burrows into the flesh of her host, a human being or some other mammal, and, being pregnant, swells to the size of a small pea, causing considerable pain and inflammation. The hinder parts of the insect project from the burrow she has made in her host's flesh, so that her eggs are laid outside the wound. After oviposition the Chigoe dies and shrivels up.

The "Plague" Flea, Xenopsylla cheopis, Rothsch., a subtropical species, but not unknown in Britain, and the common Rat Flea Ceratophyllus fasciatus, Bosc., are notorious as the carriers of the bacilli of plague from rats to man. The common human Flea, Pulex irritans, is also capable of transmitting the malady, but under natural conditions it is unlikely that it ever does so. The Bat Fleas all breed in the haunts of their hosts, and the larvæ live upon their excrement. All of these Fleas are well provided with combs, not only upon their heads, but upon their abdomens. They are thus well provided with miniature grappling irons to enable them to retain their hold on the active Bats. None of them are common, and their want of eyes is not surprising, seeing that their hosts are nocturnal. 


\section{ORDER DIPTERA, OR FLIES.}

The Diptera have two membranous, transparent, nonscaly wings (except some of the Mosquitoes, whose wings bear scales). Behind the wings are a pair of knobbed structures, resembling pins, called poisers, balancers, or halteres. The halteres are hidden by membranous shields, called "squamæ," and Flies possessing these structures are said to be calypterate. Mouth-parts adapted for sucking; metamorphosis complete.

This large order, the largest of all, is very well defined; there are few other insects, except Diptera or true Flies, which are two-winged. A celebrated entomologist has estimated that there are probably three hundred and fifty thousand species. In addition, Flies are undoubtedly the most highly organized of all the Insecta.

In colouring the true Flies cannot, as a whole, vie with the Moths and Butterflies, Beetles, or even Bugs; nevertheless, some of them are of brilliant metallic sheen and many are pleasing to the eye. In the main they are inimical to man; it is true that many are excellent scavengers, some keep harmful insects in check, but others transmit some of our deadliest diseases. Malaria, yellow fever, and sleeping sickness are all Fly-transmitted diseases. Others, again, are pests of the farm-the Crane Fly, Frit Fly, Onion Fly, and the Celery Fly, to wit.

With anatomical structures we are not concerned, but there are some points which can hardly be lightly passed over. Practically the whole of the head in these 
insects is occupied by the large compound eyes. In some species it will be found that the eyes of certain individuals are well separated, in the middle line above the head; in other individuals the eyes almost touch one another-the former are the females, the latter the males. There are, of course, many species in which the compound eyes show no difference in separation in the sexes.

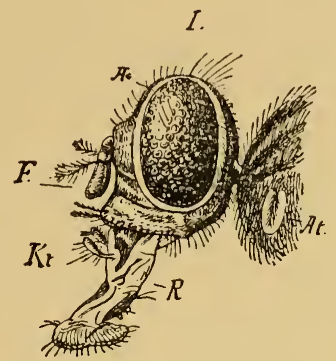

Fia. 13.-House Fly.

$L$, Head and anterior part of thorax ( $\times$ about fifteen times); $A t, A$, Spiracle on thorax; $F$, antennæ; $K t$, maxillary palpi; $R$, proboscis; $A$, compound eye.

The antennæ are important, and much of the classification of Diptera is founded upon the structure of these organs. In some families, the Cecidomyiida, or Gall Gnats, for example, the antennæ are relatively long and filamentous; in other families of the same group the antennæ of the males only are heavily feathered; this affords a ready means of distinguishing the sexes.

The mouth-parts of Diptera show considerable variety, and, with the antennæ, are important from a systematic 
point of view. Whether designed for piercing, as in the Mosquitoes, or soft and fleshy, as in the House Fly, they are all adapted for sucking liquid food. The Bot Flies provide the inevitable exception, for the majority of them have mouths so atrophied as to be useless for imbibing nourishment.

The wings are, probably, more used by systematists than any other organs in classifying Diptera. The arrangement of the veins and nervures is very characteristic in the majority of families, and forms an infallible guide to the correct position of the owner.

The larvæ of Flies are all legless. Many of them possess spines or protuberances, which enable them to move from place to place to a limited extent. Compared with the larvæ of many Moths, or even of some Beetles, those of Flies are relatively stationary. Some Dipterous larvæ are aquatic, and in such cases they possess remarkable adaptations for their especial mode of life. None are more remarkable in this respect than the so-called "rat-tailed maggots" of the common Drone Fly, Eristalis tenax, a common denizen of stagnant water in this country.

Pupæ of Diptera are of two kinds-the one very closely akin to the pupa of Lepidoptera, the other simply formed of the hardened, shrunken larval skin. The former is typical of the Orthorrhapha, though it also occurs elsewhere; the latter is confined to the Cyclorrhapha. 


\section{Series 1. Orthorrhapha Nemocera.}

Flies with pupæ akin to those of Lepidoptera and filamentous antennæ.

Cесіромуіпж.-Small, delicate Flies. Long antennæ with hirsute whorls; wings usually three-veined, the hinder vein being forked; no apical spurs on the tibiæ.

The members of this family are known as Gall Flies, or Gnats, because many of them deposit their eggs in various organs of living plants, and the larvæ which hatch out of the eggs cause the plant tissues to swell and become malformed.

The most notorious of these minute insects is the Hessian Fly, Mayetiola destructor, a very serious pest of wheat, which, in America, destroys as much as fifty per cent. of the crop in bad years. This unwelcome alien received its popular name because it was thought to have been introduced into America in the bedding of Hessian troops during the war of the Revolution. The actual damage caused by this pest arises from the fact that the eggs are placed at the junction of leaf and stem. The larvæ, when they come into the world, eat the wheat, causing a weak spot, with the result that the upper part of the stem breaks.

Although the family is large, there is very little authentic information on the subject of its members. The most striking fact about these Flies, apart from their gall-making propensities, is that certain of the larvæ exhibit the remarkable phenomenon of pædogenesis (see p. 20). Another peculiarity is the possession of a so-called "breast-bone" by the larvæ of some 
species. The use of this structure is not quite clear; it is probably connected with locomotion.

MYCETOPHILID e.-Larger than the Gall Flies; wings more veined; no hirsute whorls on antennæ; ocelli present; and a pair of apical spurs on the apex of each tibia.

From their habit of breeding in decaying fungithough some species select other putrid vegetable or animal matter-these Flies are called Fungus Gnats. More than a hundred species are known in Britain, and the little maggots so frequently encountered in mushrooms are members of the family.

The larvæ of Fungus Gnats are more elongated than is usual with Dipterous grubs. Many of them have particularly interesting habits. The larvæ of Sciara militaris migrate from time to time in enormous numbers in search of food. "Millions of the larvæ accumulate and form themselves, by the aid of their viscous mucus, into great strings or ribbons, and then glide along like serpents; these aggregates are said to be sometimes forty to a hundred feet long, five or six inches wide, and an inch in depth."

The New Zealand Glow-Worm is the larva of a Fungus Gnat, Boletophila luminosa. Not only is the larva luminous, but the Fly exhibits this peculiarity.

CuliCID s.-Wings long and slender, veins bear flattened scales; larvæ aquatic.

The Gnats or Mosquitoes are among the most important of all insects. Most of them are annoying to man, many are harmful. There are about a dozen species in Britain. In the popular mind the Mosquito is a creature more to be feared than the Gnat-in reality they are one and the same thing. 
One of the most remarkable facts concerning the Mosquitoes is revealed by a study of their geographical distribution. While some species are confined to limited areas, there are many species of very wide distribution. The common British Mosquito, Culex pipiens, L., is equally common in many parts of Asia.

Of the disease-carrying Mosquitoes, the most notorious are the Yellow Fever Mosquito, Stegomyia fasciata; the Spotted Winged Mosquito, Anopheles maculipennis; and other members of the genus; and Culex fatigans. The Yellow Fever Mosquito, sometimes called the Tiger Mosquito, on account of its characteristic markings, is, as its name implies, the carrier of yellow fever. Mosquitoes of the genus Anopheles, recognized from Culex and Stegomyia by their spotted wings, convey malaria ; Culex fatigans, and probably other species, carry filaria (minute Worms) which cause elephantiasis.

It is a peculiarity of Mosquitoes that they are most active towards evening; this is exceptional amongst the Diptera, for most of them are lovers of sunshine. The habit is not without its advantages, because it has been proved that it is possible to work and live in a malaria-stricken area and yet remain perfectly healthy, provided one retires within Mosquito-proof shelters at sundown, remaining there till morning. The transmission of disease is carried out by the females only, for they alone suck blood. In many cases the mouthparts of the males are too feeble to puncture the skin.

We have mentioned that the larvæ and pupæ of Mosquitoes are aquatic; as a consequence the females lay their eggs in water, and the various species exhibit a wide choice of breeding-places. Stegomyia, for in- 
stance, might almost be termed a domestic insect The females deposit their eggs in various receptacles near dwelling-houses; in collections of water at the bottom of disused cans, in the hollow bottoms of upturned bottles-anywhere, in fact, where there is a little water. There are Mosquitoes which breed in puddles by the roadside; their eggs are liable to come to a bad end in dry countries, owing to the evaporation of the water. Some provision, however, is made against such an untoward event by the life-cycles of these species being completed very rapidly. Most of these insects breed in ponds or fairly extensive sheets of water, but they usually select some sheltered part where their eggs are not likely to be disturbed.

The eggs of the various genera exhibit remarkable differences. Some species lay their eggs singly, and they float so on the surface of the water; the eggs of other species sink to the bottom of the water. All the members of the genus Culex lay eggs in large numbers, and seal them together with their blunt ends, from which the larvæ emerge, downwards. These eggmasses are known as "rafts." The eggs of Anopheles are laid singly, but they usually accumulate in clusters. Each egg is characterized by a pair of lateral floats containing air.

The larvæ are peculiar, almost pin-shaped creatures, which wriggle actively in the water, and either remain near the surface or come up constantly to obtain air. Although aquatic, these larvæ cannot obtain the air they require from the gases dissolved in the water, after the manner of fish. This fact has been utilized in their control, and by covering the surface of Mosquito- 
frequented ponds with paraffin, millions of the larvæ are killed. Respiration is carried out by means of a tube situated on the last abdominal segment, and the larvæ constantly thrust the tip of this tube above the surface of the water to obtain the air they require.

The pupæ are comma-shaped creatures bearing a pair of trumpet-shaped breathing-tubes on the thorax. When the Mosquitoes are about to emerge, the pupal skin splits down the back, setting free the perfect insect, which usually rests awhile on the floating skin it has just vacated before taking to flight.

Chironomidz.-Small, fragile, Mosquito-like Flies, without the projecting mouth-parts so characteristic of the last family.

The Midges are a larger, though less economically important, family than the Mosquitoes. The females are persistent blood-suckers, but, so far as is known, they do not transmit any disease, unless future researches show certain species of Ceratopogon to be the vectors of pellagra in the Nile Delta.

The larvæ of this family are not all aquatic; those of Ceratopogon bipunctatus, for example, live under moist bark. The larvæ of Chironomus, the Harlequin Fly, of which genus there are more than two hundred species in Britain, are water-dwellers, but they differ markedly from Mosquito larvæ. Owing to their intense red colour, due to hæmoglobin, they are known as "blood-worms." Hæmoglobin possesses the property of absorbing the free oxygen in water and passing it on to the living individual as required. On this account the Blood-Worms are able to spend their time in the mud at the bottom of ponds without the necessity of 
coming to the surface to breathe, after the manner of Mosquito larvæ.

The pupæ of the aquatic species are comma-shaped, though not so markedly so as are those of Mosquitoes. The pupa of the "Splay-Footed" Midge, Tanypus, might easily be mistaken for a Culicid; the Harlequin Fly pupa is easily recognized by possessing a pair of tufts of white, respiratory filaments, in place of the trumpetshaped breathing-tubes common to Mosquitoes. The Horned Midge, Ceratopogon bicolor, so called because of the single protuberance which occurs on the hinder part of the thorax in the perfect insect, has a long, eel-like larva, measuring about half an inch. Its pupa is not curled into a comma shape, though it possesses the usual pair of trumpet-shaped breathing-tubes. This is a common British Midge.

PsychodId ж.-Small, fragile Flies, resembling minia ture Moths. Bodies, wings, and antennæ thickly clothed with hair.

These insects are known as Sand Flies or Moth Flies, on account of their hairy covering; there are about fifty species in Britain.

Most of the larvæ are peculiar in that they are adapted for life either in water or on land; they have tracheal gills and spiracles. The larvæ of the purely landdwellers live in various substances such as dry cowdung, rotten potatoes, and the like. The aquatic larvæ either frequent pools or running streams, and the latter forms are possessed of sucker-like organs by which they anchor themselves to some support that they may not be carried away by the current.

There is a South European species, Phlebotomus 
pappataci, which of late has earned considerable notoriety by reason of its carrying to man the unknown germs of a very infectious disease, variously known as "three-day," "sand-fly," or " phlebotomus" fever.

DIxID e.-Flies with three forked veins in the outer half of each wing, and two cross-veins. Larger than any of the preceding species.

These Flies are not of any great interest, but they are mentioned here because they form a natural link in the chain of families between the species already mentioned and those to be mentioned. They occur in damp, well-wooded spots; the larvæ and pupæ are aquatic, and the perfect insects do not bite. The immature species might easily be mistaken for those of an Anopheles Mosquito. There are four British species of the single genus Dixa which comprises the family.

TIPULIDA.- The middle of the upper side of the thorax marked with a distinct $\mathbf{V}$-shaped groove; wing venation complex. The largest Flies of the Nemocera are all possessed of exceedingly long legs.

The Crane Flies, or Daddy-long-legs, are well known to everyone. They claim our attention for several reasons. The family contains the most primitive forms of living Diptera; many species, notably the Chinese Tipula brobdignagia, are of considerable size. There are a great number of forms which, superficially, bear little resemblance to the typical Crane Fly. Some, in fact, are wingless. Their habits are as varied as their forms; one species dwells in deep mines, and many species can only flourish at low temperatures.

The common Daddy-long-legs, Tipula oleracea, is so 
well known that a description of it is unnecessary. One scientist has aptly termed it a silly insect, and certainly these clumsy creatures appear to fly about our rooms and gardens without any apparent object. When handled, they lose their legs as readily as certain of the long-legged, so-called Harvest Spiders; furthermore, the loss of these limbs seems to cause them but little inconvenience.

The female lays from two to three hundred eggs, as she flies vertically over the ground. The larvæ bury themselves in the soil, and feed upon the roots of grasses, etc., doing a considerable amount of damage. When fully fed they are repulsive, earth-coloured creatures about an inch long, and with such tough skins that they have earned the name "leather jackets." The pupæ might easily be mistaken for those of some Moth, were it not for the pair of breathing-tubes which project from the head like a pair of horns. When the Flies are about to emerge, the pupæ wriggle to the surface of the soil by means of the backwardly projecting spines with which they are armed. When their heads are well free of the soil they stop their efforts to travel further, the pupal case splits, and the Daddy-long-legs is free.

Though many larval Tipulidae are earth-dwellers, some are aquatic, and possess remarkable elongated breathing filaments. An American Bittacomorpha has these tailed larvæ and pupæ, and a British Ptychoptera has equally peculiar pupæ.

BIBIONIm.-Antennæ short, thick, and straight; ocelli present. Front tibiæ often swollen or furnished with a long spine or a circlet of spines. Colours of the sexes frequently vary. 
The March Flies (they usually appear in the spring) are uninteresting, sluggish, hairy creatures. None of them are good fliers.

Their greatest claim to notice lies in their Caterpillarlike larvæ, with distinct horny heads-unusual among the Diptera; the fact that males and females of the same species are frequently of different colours-these colour differences occur all over the world; and in the peculiar structure of the compound eyes of the males, consisting of a large, hairy upper portion and a much smaller, differently faceted lower portion.

Simulindж.-Small, thick-set, hump-backed Flies. Wings broad; antennæ short and of the same width throughout their length, not hairy.

From their peculiar hump-backed appearance, these Flies are known as Buffalo Gnats, owing to a supposed resemblance to the buffalo; they are also called Black Flies and Sand Flies-an unfortunate name, because it is also applied to the Moth Flies. There is only one genus (Simulium) in the family, and the females of all the species are persistent blood-suckers. In seasons favourable to the Flies they appear in enormous numbers, and attack domestic animals and even man. Unlike Mosquitoes, they bite by day; unlike these insects, also, they live, during their immature stages, in swiftly running, well-aerated water.

The life-history of a typical Simulium is one of the most romantic among the Diptera. The females appear in the spring and haunt swift-running streams in search of suitable places for egg-laying. Hovering for a moment above some slightly submerged rock, over which the water is flowing, the mother Fly will suddenly 
dart downwards and deposit her eggs upon the rock. Owing to their jelly-like covering, the eggs adhere to the spot where they are deposited. The larvæ are curious, somewhat elongated creatures with a sucker foot at the hinder end, by which they support themselves in a vertical position on the rock. On the first segment there is another sucker-like protuberance; on the head there are a pair of fan-shaped, plumose structures whose function appears to be to waft food material towards the mouth. For long periods the larvæ do not move from their original positions; when, however, they desire to do so, they progress by a looping movement similar to that of a Looper Caterpillar, by attaching themselves to the rock with their forward and hind suckers alternately. In case of failure to obtain a firm hold of their support, they would be carried away on the stream, were not provision made against such an event. From their mouthr they spin a thin but strong life-line, and attach the frce end to the rock; forced, by accident or alarm, to release their hold of their support, they remain suspended on the life-line till the danger be passed, when they haul themselves back again to their resting-place.

When pupation is about to take place, the larva spins a slipper or pouch-shaped nest, either on the rock or on the submerged leaf of some water-plant. Within the pouch, its head alone projecting, the pupa dwells till such time as the Fly is ready to emerge. From the head of each pupa there project a pair of filamentous, branched gill filaments, which serve for respiration. As the time for the emergence of the Fly draws near, a tiny bubble of air collects within the pupal pouch. 
In this bubble the Simulium leaves its pupal skin, shakes the bubble free, and, within it, rises to the surface of the water without wetting its wings.

The Simulidos are widely distributed, being practically cosmopolitan. The commonest British species are Simulium elegans and S. sericeum. In this country they never appear in such enormous numbers as in warmer climates. Obnoxious as the Buffalo Gnats are to cattle, they are also more than suspected of transmitting pellagra from man to man. This disease, common in Italy and spreading in America, is not by any means unknown in Britain.

\section{Series 2. Orthorrhapha Brachycera.}

Flies with pupæ akin to those of Lepidoptera, and antennæ usually composed of one, two, or three segments, with a terminal appendage.

Stratiomyide.-Antennæ three-jointed, often with an arista; tarsi with small terminal appendages; scutellum frequently spined.

The members of this family are so variable that it is difficult to find a simple, non-technical description which will apply to all. The name Stratiomys means " Armed Fly," so called on account of the pair of spines on the scutellum. All the species, however, do not possess these spines. In America they are called Soldier Flies, because of the bright colouring of some species.

The most extraordinary species are those whose larvæ live in the hot springs of Wyoming. So hot is the water in these springs that the discoverer of the 
larvæ was unable to keep his hands immersed. The larvæ of many species are truly aquatic, but those of other species frequent the soil, moss, decaying wood, and Ants' nests; all of them appear to prefer damp places.

Of the thousand odd species in the world, more than fifty occur in Britain; of these, the commonest is the Chameleon Fly, Stratiomys chameleon.

The Chameleon Fly is a Bee-like creature, black with yellow markings. The female lays her eggs in clusters on the under-sides of water-plantain leaves, at a point above the water-level. As soon as the larvæ emerge, they make their way into the water. They are elongated creatures, and their tails terminate in a circlet of hairs; in the centre of the circlet the spiracles are situated. The larvæ float head downwards in the water, with their tails supported on the surface by the hairs. When alarmed, they wriggle downwards, retaining a bubble of air in their caudal appendages. Pupation takes place either in or out of the water. In the former case the pupa floats on the surface, encased in the last larval skin.

LEPTID \&.-Antennæ three-jointed and terminated by a bristle; squamæ small or rudimentary; at least one pair of tibiæ furnished with distinct spurs at the apex of the inner side.

Known as Snipe Flies, the Leptidce bear a close resemblance to the Robber Flies. They are of sluggish habit when adult, and the predaceous larvæ live in water, earth, or decaying wood, according to the species.

About a score of species are known in Britain, the most frequently encountered being Leptis scolopacea. The larvæ of Vermiteo degeeri, a common European 
species, construct pitfalls after the manner of Ant-Lion larvæ (see p. 130). Another British species of curious habit is Atherix ibis. A female will deposit her eggs on the tip of some branch overhanging a pond, and, having done so, will cling to the egg-mass and die. Other females of the species do likewise, till, in time, a bunch of considerable dimensions is formed of dead Flies and their eggs. Eventually the mass falls into the water, the eggs hatch, and the larvæ are set free.

TABANIDAs.-Antennæ four-jointed, the second very small, the third annulated; squamæ very large; tibiæ with terminal spurs on at least one pair.

With the exception of the Muscidae and Culicida, the Horse Flies, Gad Flies, Breeze Flies, Cleggs, and Deer Flies, as the Tabanidos are variously termed, are by far the most important family of Dipterc. They are powerful fliers, and the females are so bloodthirsty and so well armed for the purpose that, in the larger species at any rate, they are capable of inflicting serious wounds.

The larvæ of all the species are predaceous, feeding upon soft-bodied insects and worms. They are characterized by their cylindrical shape, pointed at either end, and surrounded with prominent rings. Some are aquatic, but the land-dwelling species appear to favour damp places. The adult Flies also frequent the neighbourhood of water, not only for breeding purposes, but because they are great water-drinkers.

Our largest British species, Tabanus bovinus, is a formidable-looking nearly black Fly, with the ventral surface of its abdomen of a reddish hue; well-grown specimens are fully an inch in length. 
The genus Homatopota contains several British species, all of them bloodthirsty creatures which do not hesitate to bite man.

All the species of Chrysops are beautifully marked, usually yellow and black Flies, about the size of the common House Fly. Their beauty is enhanced by the brilliancy of their eyes while they are alive. They are no less bloodthirsty than other members of the family. The Tabanidoe are well represented in Britain, seeing that we have five genera and nearly a score of species.

The most remarkable genus is Pangonia, widely distributed, though not known in Britain. The males live upon nectar, but the females of several species have long, needle-like proboscides, about four times the length of the insect's body, and capable of piercing clothing. These and other Tabanida are the prey of Bembex.

ScENOPINIDA.-Small, non-hairy Flies. Antennæ three-jointed, without any terminal appendage; the third joint longer than the others.

The Window Flies form one of the smallest families of Diptera, and little appears to be known about them. Our common Window Fly, Scenopinus fenestralis, L., is a metallic-black insect, frequently found on windows, as its specific name indicates. Its larvæ are predaceous and live under carpets and in dusty places; they are supposed to prey upon the larvæ of Carpet Moths, though proof of this assertion is still wanting.

BomBYLIID A.-Bodies fringed with or clothed with hair; wings usually mottled or banded; antennæ threejointed.

The Bee Flies cannot very well be mistaken for any other Diptera on account of their characteristic hirsute 


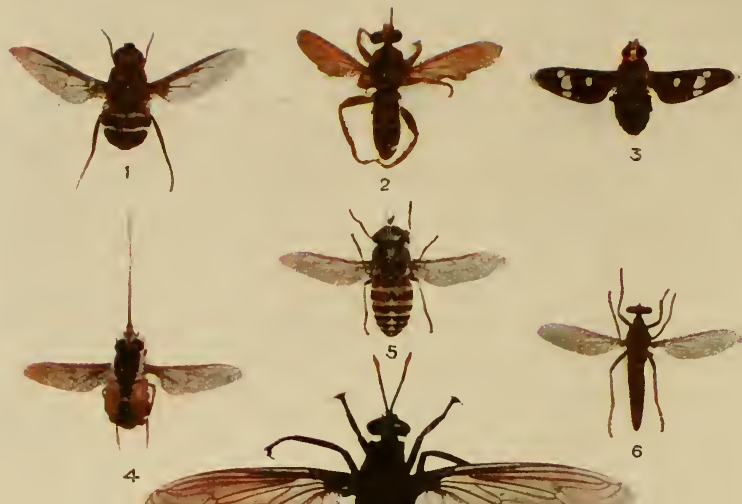

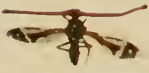

7

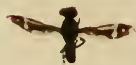

10

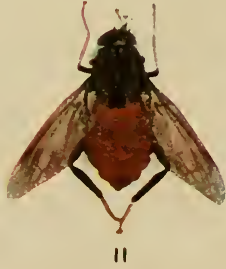

A GROUP OF DIPTERA
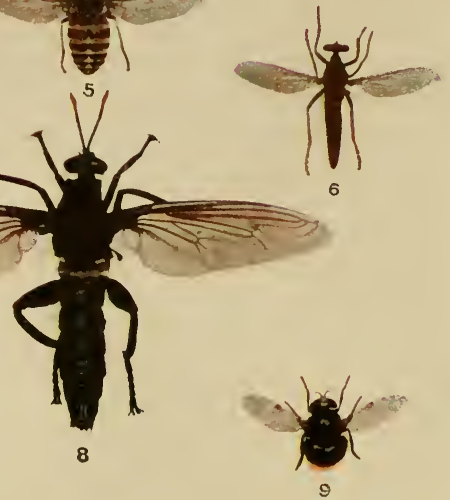
Nos, $2,6,9$ and 11 are Robher flies; No. 4 , Pammonia $x p . ;$ No. 5 , the large British Gadfly ; No. 7 , 
covering. Though the family is large, but few species are found in Britain, Bombylius major being the most remarkable in appearance and in habit. Though possessed of formidable-looking mouth-parts, none of the species are blood-suckers.

In the main, the Bee Flies are beneficial. Several species are known to devour the eggs of Locusts, some species are parasitic upon Bees. Fabre described the relationship between the Bombylid Argyromoba trifasciata and the Mason Bee Chalicodoma muraria. The female Fly deposits an egg on the structure built up by the Mason Bee as a home for its family. From the Dipterous egg a minute, worm-like larva emerges. For more than a fortnight this larva remains quite motionless, then begins the hunt to find a crack in the masonry through which to gain admittance to the interior. At length a way is found, usually at the time when the Bee grub is almost ready to pupate. When once inside the Bee's home, the Fly larva casts its skin and appears in a new form, well fitted for the object it has in viewnamely, to feed upon the Bee pupa without killing it. The mouth of trifasciata is merely a sucker, which is applied to the soft skin of the Hymenopterous pupa. At the end of a fortnight the pupa is sucked dry and the larva is fully fed. To be replete yet incapable of escape from confinement is hardly an enviable position, yet the larva is in such case. Patience is second nature with the larva. It displayed marvellous patience in its attempts to penetrate the Bee-made masonry; it displays equal patience in this second emergency, waiting in a quiescent larval state till the following spring, when it again moults and appears as a pupa well fitted 
for its task. Its large head is armed with six formidable spines, its tail is provided with horns, and its body is clothed with backwardly directed bristles. The horns and bristles prevent the creature slipping backwards during its efforts to escape. Curving itself into a C-shape, it suddenly unbends and strikes its head against its prison walls. Eventually the wall is broken down, the pupa wriggles about till it fills the cavity which has been formed by its own exertions, the pupal skin bursts, and the Fly escapes.

AsILID\&.-Flies with large, hard beaks tipped with stiff bristles. Feet and claws large; squamæ absent; strongly built and hairy; antennæ three-jointed, with a terminal appendage.

This is one of the largest Dipterous families, containing more than three thousand species. Though the species assume varied forms, from short, stumpy, very hairy Flies to long, delicate, almost Midge-like individuals, there is a family likeness which cannot be mistaken. The Asilidae are known, and rightly so, as Robber Flies. An American entomologist says: "These flies are inhuman murderers. They are savages of the insect world, putting their captives to death with merciless cruelty. Their large eyes, divided into such a multitude of facets, probably give them the most acute and accurate vision for espying and seizing their prey; and their long, stout legs, their bearded and bristly head, their whole aspect, indicates them to be of a predatory and ferocious character. Like the hawk, they swoop upon their prey, and grasping it securely between their fore-feet, they violently bear it away."

The Robber Flies are all exceedingly voracious; their 
prey is captured on the wing, and immediately the lancet-like mouth-parts are plunged into the body of the victim and held in place by the stiff bristles which clothe the tip of the beak. Their prey consists of Flies, including those of their own species, Bees, Wasps, Beetles, Moths, Butterflies, Grasshoppers, and even powerful Dragon-flies.

A striking peculiarity about many of these Flies is that they frequently closely mimic the insects upon which they prey. One Bee-hunting species even goes so far as to have its hind-tibiæ so modified that they resemble the pollen-carrying hind-legs of Bees. This aggressive mimicry, as it is sometimes called, is of great service to the Robber Flies; it enables them to fly amongst their victims without arousing suspicion, and their prey is thus the more easily captured. Although the adult $A$ silida are totally unlike the adult Tabanido, and the two families are but distantly related, their larvæ are so similar that it is almost impossible to say definitely to which family they belong.

EMPID正.-Flies with small globular heads; antennæ three-jointed, the third joint being long and pointed; legs long and often hairy.

A large family of unimportant, uninteresting creatures, called Dance Flies, on account of their curious jerky flight. There are at least two hundred species in Britain, and they usually frequent well-wooded districts. The males of certain species possess the curious habit of carrying webs of some sticky substance during their dancing flights; the precise use to which these webs are put has never been ascertained. It has been suggested that they act as parachutes or aid in the capture of 
prey. One observer stated that the females, when selecting a mate, always decided upon the male with the largest web.

\section{Series 3. Cyclorrhapha Aschiza.}

Flies with pupa-cases formed of the hardened larval skin and no arched suture over the antennæ of the adults.

PIPUNCULID ж. - Small Flies with globular heads, covered almost entirely by the two large compound eyes. Antennæ very short, bearing a long, nonterminal bristle.

For want of a better name, these insects have been called Big-Eyed Flies. The family is a small one, and it has not received very much attention from entomologists. About a dozen species are known in Britain. The larvæ of some species are parasitic on the Homoptera, that of Pipunculus fuscipes attacking certain Jassidoe.

CoNOPID $\approx$.-Flies with large heads and three-jointed antennæ, placed close together on a slight protuberance. The family consists of two divisions-(a) Conopince, with long antennæ terminated by a small bristle; (b) Myopince, with shorter antennæ, the third joint possessing a non-terminal hair.

The life-histories of the "Thick-Headed" Flies have not been fully elucidated. It is certain that many of the Conopina, and probably also of the Myopinae, are parasitic on Hymenoptera. Exactly how they attack their hosts does not seem clear. Some observers state that the Flies deposit their eggs in the bodies of the larval or pupal Hymenoptera; others aver that the eggs are deposited upon the bodies of the adult hosts. One 

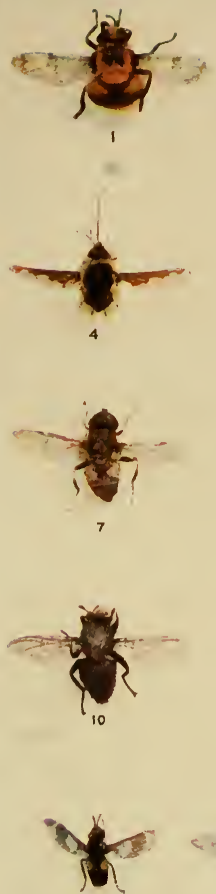

13
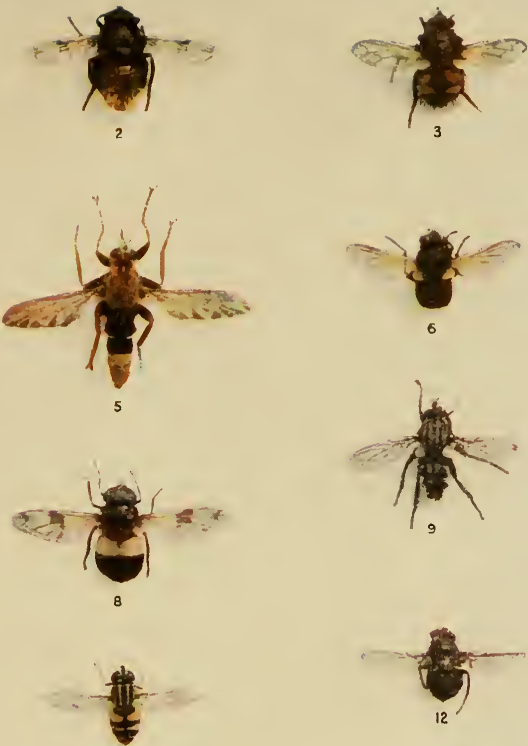

11
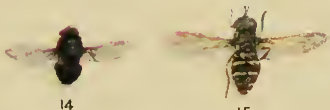

15
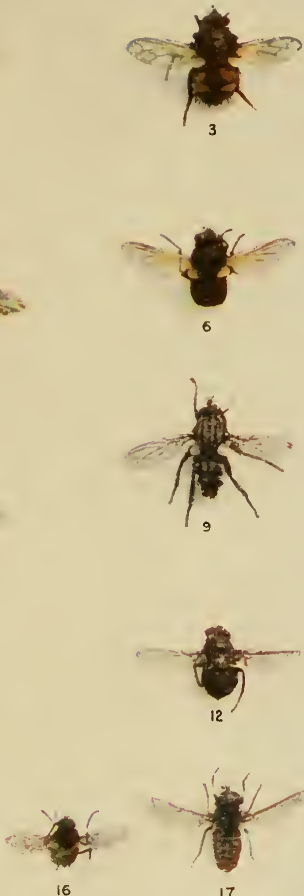

16

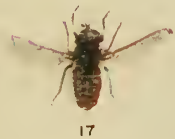

BRITISH FLIES

Nos. 1, 2 and 4, Bee flies; Nos. 3 and 10. Blow flies; No. 5 . Robber fly; No. 7 , Drone fly; No. 8 , Cheilosia lencorum; No. 9. Flesh fly; Nos. 11 and 15, Horn fles; No. 12, House fly; No. 13, Golden-eved Gadfly; No. 14, Green-bottle; No. 16, Rhingia sp.; No 17, Horn fly. 

fact is clear: the parasitic Flies always make their appearance from the bodies of adult Hymenoptera.

SyrPHID\&.-Moderately large, usually flat-bodied Flies. Many of them mimic Bees and Wasps. Short, three-jointed antennæ, with a non-terminal bristle; squamæ never entirely covering the halteres.

The Hover Flies comprise one of the largest families of Diptera, and certainly the most important of the Cyclorrhapha Aschiza. They are as well known as the common House Fly; it is impossible to go into any garden or sunny glade on a bright summer day without observing numbers of these insects hovering hawk-like above some favoured blossom.

There is no more interesting family of Flies than the Syrphidae. Some species afford excellent examples of protective mimicry; at a casual glance these Flies may resemble Social or Solitary Wasps, Honey-Bees, Bumble Bees, and the like. One species, closely resembling the Honey Bee, is wont to deposit its eggs in decaying animal matter. Seeing that no Honey Bee has ever been known to select such a site for its nest, there is good reason to suppose that this mimicking Hover Fly is the insect referred to in the Old Testament story of Samson. While most of the Syrphids are flatbodied, yellow-banded Flies, some have elongated bodies, and some are of a metallic-green colour.

The adult Hover Flies all feed upon pollen; their larvæ are of most diverse habits. Some are aquaticfor example, Eristalis tenax and Myiatropa florea, both common in Britain; some live in Bees' and Wasps' nests -of these, Volucella inanis is well known in this country; some, and they are the useful members of the family, 
are predaceous upon Green Fly. Nearly every garden will show these individuals busy among the Aphids; Syrphus seleniticus is a species frequently met with. On the other hand, there are injurious species in the genus Merodon, the Narcissus Fly, M. equestris, being responsible for considerable damage to bulbs. Most anomalous of all, however, are the larvæ of the genus Microdon, which live in Ants' nests, and are so unlike insect larvæ that their appearance has deceived scientists, and they have been described as molluscs.

The larva of the Drone Fly, E. tenax, is known as the "rat-tailed" maggot. The Fly, a creature of the sun and a lover of sweet-scented flowers, lays her eggs on the surface of liquid manure or of some evil-smelling, stagnant water. The larvæ, when they emerge, crawl about on the bottom of the liquid, feeding upon the decaying matter, and keeping in touch with the air by means of their curious, telescopic tails. The full-grown larva measures about two-thirds of an inch long; its tail can be extended to as much as five inches. At the tip of the tail is a circlet of bristles, and within the circlet are the spiracles, in communication with the maggot's respiratory apparatus. As the creature passes from one part to another of its liquid home, it contrives to keep this circlet of hairs always floating on the surface; this it does, within limits, by extending its tail as the liquid becomes deeper, and contracting it when a shallower place is reached. Pupation usually takes place in the soil.

The Hover Flies of the genus Volucella mimic Bees and Wasps. It was once thought that their larvæ preyed upon Hymenoptera, but observation showed that the Flies were by no means unwelcome visitors. $V$ inanis 
mimics the common Wasp; its eggs are laid in Wasps' nests, and its larvæ act as scavengers in their strange home, passing from cell to cell and devouring the excrement of the immature Wasps. $V$. bombylans, another common British Hover Fly, mimics the Bumble Bee, and its larvæ also act as scavengers.

Of what use, if any, the larvæ of Microdon are to Ants has not been ascertained. Observers have stated that the Ants try to prevent the Flies from laying their eggs in their nests. It is probable, therefore, that at least the Ants derive no benefit from the presence of their dipterous visitors.

\section{Series 4. Cyclorrhapha Schizophora.}

Flies with pupa-cases formed of the hardened larval skin, and having an arched suture over the antennæ of the adults.

By most authorities the series Cyclorrhapha Schizophora is divided into two groups:

(a) Calypteratce, with the lower squama distinct and usually projecting beyond the upper.

(b) Acalypteratce, with the lower squama minute or wanting and the eyes widely separated in both sexes.

\section{Group Calypteratce.}

CEsTRIDæ.-Large, robust flies; antennæ very short and partially hidden in cavities; front of head prominent; mouth-parts often atrophied.

The Bot Flies, though a small family, are of the greatest economic importance by reason of the fact that many of their larvæ are parasitic on mammals. 
Much remains to be learned concerning the lifehistories of these extraordinary Flies. One thing only is certain: the larvæ alone are harmful. The adults are not blood-suckers-in fact, few of them are able to feed at all, their short lives being devoted to the continuation of their kind. The larvæ feed upon the pus which is secreted by their hosts, in consequence of the irritation set up by the spiny larval skins. Pupation always takes place outside the body of the host.

Of the ten British species of Bot Flies, the best known are the Horse Bot Fly, Gastrophilus equi, the larvæ of which, in common with others of the genus, live in the alimentary canal of their hosts; the Ox Warble Fly, Hypoderma bovis and $H$. lineata, living in the larval stage, as the generic name implies, beneath the skin of their host; and the Sheep Nasal Fly, Estrus ovis; the larvæ of this genus live in the respiratory passages. Other interesting, though non-British members of the family are the Emasculating Bot Fly, an American species which attacks the scrotum of squirrels, rendering them sterile; and the members of the genus Dermatobia, which are parasitic on man.

The Bot Flies are not easily observed; they spend much of their time resting; but when bent on egglaying they display much activity. The Horse Bot Fly, for example, with much buzzing, will dart rapidly at the fore-legs of its chosen host, deposit a single egg upon a single hair, and fly away. This operation is repeated till a good complement of eggs has been laid. Each elongated egg is provided with a little lid at its free end. The presence of the eggs causes irritation to the horse, with the natural result that it resorts to 
licking for relief. The friction of its tongue, aided by its saliva, causes the egg-lids to open, and the larvæ are set free. Once within the mouth of their host, they are well on the way to their appointed resting-place. They travel to the stomach, develop anchoring hooks, with which they attach themselves securely to the walls of that organ. Food they obtain in abundance, food intended for the nourishment of their host. When the time arrives for pupation, they release their hold on the stomach wall, pass to the outside world along with the horse's excrement, and pupate in the soil.

The Sheep Nasal Fly is even more shy than the preceding species. It settles but a moment on the nostrils of some sheep and deposits its eggs, which hatch almost immediately. So short is the egg-stage that some authorities are of opinion that this Fly is viviparous and gives birth to living larvæ. Be that as it may, the young larvæ, by the aid of their spiny coats, travel upwards to the frontal sinus of their host, where they feed on copious secretions of pus. No amount of sneezing on the part of the sheep (sneezing is a common indication of the presence of these parasites) will dislodge them till they are ready to pupate, then they pass to the earth.

The Ox Warble Flies deposit their eggs upon the hair of oxen, in such places as they are easily licked. The larvæ, when in their host's mouth, do not pass into the stomach after the manner of the Horse Bots, but travel subcutaneously through the tissues till they reach a spot just below the hide on either side of the backbone. These larvæ are the cause of the well-known warbles, which are not only harmful to the living oxen, but 
render the parts around the warble unfit for food and ruin the hide for leather. In North America certain tribes of Red Indians are in the habit of squeezing the larvæ of Bot Flies from the backs of deer and using them as food.

TACHINID A.-Squamæ large, covering the halteres; antennal arista bare or, at most, pubescent; upper surface of the body clothed with bristles.

These Flies do not appear to have any popular name. By the uninitiated they might easily be mistaken for House Flies. Their chief claim to notice lies in the fact that nearly all of them are parasitic upon other insects -lepidopterous Caterpillars for the most part. In the case of the majority of parasites there is a definite relationship between the parasite and host species; among the Tachinidoe, however, the same species of parasite has been observed to parasitize not only " insects of several different families, but of two or even three different orders." The usual procedure is for the female Fly to deposit an egg, or eggs, upon the back of some unfortunate Caterpillar. Most parasites will not trouble with a host which has already been attacked by some other parasite; these Flies, however, are not so particular. From the portion of the egg in contact with the host skin the larva emerges, and at once bores its way into its body, where it lives upon the fat and lymph, carefully avoiding the vital organs till the time of pupation arrives, when it leaves the host to pupate in the ground. Frequently the host Caterpillar sheds its skin before the parasitic larva has hatched; in this event the work of the mother Tachina is brought to naught, and the Caterpillar, unless again attacked, 
suffers no harm. Some of these Flies deposit their eggs upon the living insect food collected by Solitary Wasps for their larvæ. A Japanese species, Ugimyia sericaria, does considerable damage among the Silkworms of that country by attacking the larvæ. Contrary to the usual Tachinid habit, this species deposits its eggs upon the leaves which serve as food for the Silkworms. The larvæ probably hatch on the leaves and then attack their hosts, though some observers state that the eggs are swallowed by the Silkworms.

In the main, the Tachinidae are beneficial to man, certainly the two hundred odd British species may be so classed. Entomologists will, perhaps, not agree with this assertion, knowing only too well how annoying it is when an attempt is being made to rear some treasured larvæ to maturity only to be rewarded by the appearance of drab Tachinid Flies.

SARCOPHAGID \&.-Closely allied to the Tachinidoe and the Muscida, from which they may be distinguished by the fact that the arista is feathery at the base and hair-like at the apex.

Flesh Flies - the name, though generally accepted, is hardly a good one, for many larvæ live upon decaying vegetable matter and some are parasitic upon other insects. The most noxious Flesh Fly is the viviparous Sarcophila magnifica, a European, though not British, species which deposits its young on the nostrils of mammals, including man. The commonest British species are S. carnaria, a heavy-bodied grey Fly, rather larger than a Blowfly, and the similar-sized, bright metallic blue Cynomyia mortuorum.

"Many of these insects, when food is scarce, eat their 
own species with eagerness, and it seems probable that this habit is beneficial to the species. The parent fly in such cases usually deposits more eggs than there is food for, thus ensuring that every portion of the food will be rapidly consumed, after which the partially grown larvæ complete their development by the aid of cannibalism. It is thus ensured that the food will raise up as many individuals as possible."

Muscme.-Closely resemble Tachinidoe and Sarcophagida, but the arista is feathered.

This family contains many of our commonest and most familiar Flies; amongst them may be mentioned the House Fly, Musca domestica; the Bluebottles or Blowflies, Calliphora erythrocephala and C. vomitoria; the Greenbottles, Lucilia ccesar; the Horn Fly, Homatobia serrata; and the Stable Fly, Stomoxys calcitrans. Amongst the important foreign Muscids mention must be made of the Tse-tse Flies, Glossina spp., and the Screw-Worm Fly, Chrysomyia macellaria; the former genus belongs to Africa, the latter to North America.

Many members of this family are harmful to man and his belongings. The Glossince transmit the blood parasites of sleeping sickness to human beings, and of Nagana to domestic animals. The Stable Fly is the probable carrier of surra, a disease which attacks camels, elephants, buffaloes, and dogs; it is probably not altogether innocent of transmitting human disease. No fewer than half a dozen maladies are known to be carried from patient to patient by the House Fly. The Screw-Worm Fly and the Horn Fly are both serious cattle pests in America, and the former has been known to attack man with fatal consequences. The Blue- 
bottles cannot, at best, be considered in any other light than as nuisances. After this indictment it is only fair to add that, in general, the Muscidoe are useful scavengers, owing to the fact that their larvæ live upon decaying animal and vegetable matter.

As it is our purpose to take a general survey, however brief, of all the more important members of the insect world, we cannot afford the space to deal with the various Muscid species as we would wish. Dr. C. G. Hewitt's excellent little work on House Flies should be read by all who are interested in this family. It makes no mention, however, of the most important of all Muscids, the Tse-tse Flies, for they are not House Flies. These insects of the genus Glossina have earned their popular name from the African natives who think that Tse-tse most nearly approximates to the buzzing of the Flies.

Sleeping sickness is caused by a blood parasite, known as Trypanosoma gambiense, and it is introduced into the human blood by the bites of either Glossina palpalis or G. morsitans. The latter species also transmits the blood parasite of Nagana, $T$. brucei, to domestic animals.

The Glossince are mud-coloured creatures which carry their wings scissor-wise when at rest. They possess the curious habit, for Muscids, of producing living larvæ in such an advanced stage that they at once change into pupæ.

ANTHомyindes.-Very similar to House Flies, but with a different wing venation, the fourth longitudinal vein running straight to the margin, not upturned, as in Muscidoe; arista either feathered or bare.

These Flies, which have no popular name, are, for the 
most part, unattractive. Their habits are so varied that experience will probably cause the family to be split up. Certain British species are harmful. Hylemyia cepetorum, the Onion Fly, lays its eggs on the necks of onions or on the soil near-by, and the larvæ at once pass down into the stems and irretrievably damage the plants just above the swelling bulbs. The Cabbage Root Fly, Anthomyia brassica, lays its eggs in close proximity to Cruciferous plants, and the young larvæ feed upon the roots, causing the plants to become discoloured, to wilt and die. Another species of Hylemyia, H. strigosa, is viviparous, whilst two species of Anthomyia, $A$. cana and $A$. angustifrons, are enemies of Locusts.

\section{Group Acalypteratce.}

Scatophagid ж.--Slender Flies, yellowish or black in colour; smooth or hairy.

The Dung Flies are of little general interest. The Common Yellow Dung Fly of this country is a familiar object on the excrement of cattle, on which it breeds.

SEPSIDæ.-Small, slender, shining black Flies.

The best-known species of the family is the Cheese Skipper, Piophila casei, L. The female lays her slender white eggs preferably on the best-quality cheeses. In a day and a half the larvæ emerge. In a week they are fully fed; their most striking characteristic is that by bending themselves so that head and tail meet and then suddenly straightening themselves out, they are able to leap to a very considerable height.

OrTaLID .-Wings brown, spotted or banded; bodies with metallic coloration. 
Many of these beautiful little Flies, during the larval stage, live in fruit or vegetables, but they probably only do so after damage has been caused by other insects.

TRYPETID A.-Beautifully spotted bodies in many species, and spotted or banded wings.

The Fruit Flies are considerable pests in some parts of the world, and one species, the Mediterranean Fruit Fly, Ceratitis capitata, is one of the worst enemies of the fruit-grower, so much so that stringent regulations are enforced to prevent its entry into the United States.

Diopside.-Very broad heads, eyes at the extremities of stalks.

The Stalk-eyed Flies are amongst the most curious of all Diptera in appearance, and there their interest ends. In many species the eyes are set upon very long stalks, a fact which gives their owners the appearance of possessing antlers.

OscinID \&.-Small, stoutly built Flies, often yellowish in colour.

The most notorious member of this family is the Frit Fly, Oscinis frit, a serious grain pest, and only too common in this country. Various members of the genus Chlorops damage crops by causing the plants to form galls.

DrosophILIDe.-Minute and unimportant insects, known as Lesser Fruit Flies. The adults both feed upon and oviposit in decaying fruit, and the larvæ of some species, white, eel-like creatures, are frequently found in vinegar and badly tinned fruit.

AGromyzid a.-Minute dull-coloured Flies. Of little importance. The larvæ of some species damage foliage leaves by tunnelling between the upper and lower epidermis. The larvæ of other species prey upon Scale insects. 


\section{Series 6. Pupiparia.}

Flies with heads and bodies depressed, the former projecting forward and downward; wings present, rudimentary, or absent; claws large.

Нтроовозстж.-Parasitic Flies upon animals and birds; they are peculiar in that they produce neither eggs nor larvæ, but pupæ, only a single pupa being produced at a time.

Hippobosca equina, the British Horse Fly or Forest Fly, is common on the ponies in the New Forest, though it is not confined to that district. It is a chestnutbrown, winged insect, and bears little resemblance to the commonly accepted typical Fly. Still less Fly-like is the Wingless Sheep Tick, Melophagus ovinus. This creature, by the way, is not a tick, for ticks are not even insects. It is truly parasitic and beautifully adapted for life amongst the wool of its host. The family has been neglected by scientists, and many species are probably as yet undiscovered.

BRAULIDA.-Only one species is known in this family, the minute Braula coca, parasitic upon Bees.

NyCTERIBIID \&.-Rare and curious, Spider-like Bat Flies.

The legs of these wingless Flies are long, their bodies are small, and their eyes are wanting. "They are rarely more than one-sixth of an inch in length, but the long legs, which are frequently banded with jet black and silvery white, render them quite conspicuous." Of one species Sharp says: "The form is very peculiar, the insects looking as if the upper were the under surface." 
Here our review of the insects of the world is ended. None of the important orders have been omitted and few of the families; some, we fear, have been dealt with superficially, but we have tried to be just and devote the greater space to insects of major importance. A work of more than twenty volumes has been devoted to Lepidoptera alone; therefore, to compress all that one would say into 320 pages is not so easy as it may appear. For our shortcomings and omissions we crave pardon; our one hope is that readers who have borne with us thus far may feel a desire to go into the fields, to gain access to some representative collections, and learn, by the only satisfactory means, by personal observation and study, more of Insect Life. 


\section{APPENDIX}

\section{SOME BOOKS WHICH MAY BE READ WITH ADVANTAGE}

IT is usual, when one wishes to draw attention to certain books, to enumerate a formidable list of works, in alphabetical or chronological order, under the heading "Bibliography," and leave one's readers to pick for themselves. To the experienced entomologist such a list may appeal; he knows what he is looking for, and uses the list merely for reference. It is our object to be helpful and to point the way; at a later stage our readers will then be able to use a Bibliography to the best advantage.

\section{General Works.}

The student who wishes to gain a thorough insight into general entomology cannot do better than read the fifth and sixth volumes of the "Cambridge Natural History." Its information is, of necessity, more complete, but it is also far more technical than the subjectmatter of "Insect Life." It is a standard work, but a new edition would be welcomed by every entomologist. Carpenter's "Life-Story of Insects" is brief, but excellent.

"Insects," by Harold Bastin, is another book which 
may be read with advantage by the most inexperienced student. It is accurate though popular, and well illustrated.

The works of M. Fabre, most of which have been translated into English, are so delightful, so pregnant with romance, that even those whose interest in insects is superficial have read them and will read them.

The "Insect Book," by Howard, is a splendid work as far as it goes. It deals with American types, however, while Coleoptera and Lepidoptera are missing from its pages.

\section{ODONATA.}

"British Dragon-flies," by Lucas, is the best work for the beginner. Practically all our British species are figured in colour.

\section{ORTHOPTERA.}

So far as we know, there is no work dealing solely with this order and suitable for any but advanced students. All the general works we have mentioned deal with the order.

Rhynchota.

The remarks under the previous heading apply also to this order.

\section{LEPIDOPTERA.}

" British Butterflies,” by A. M. Stewart, and “ British Moths," by the same author, will be found especially useful to readers of "Insect Life," for they contain 
concise and accurate descriptions of all the British species figured in "Insect Life." They are excellent little works. The volumes with similar titles to the above, by South, are also worthy of perusal.

The "Butterfly Book" and the "Moth Book," both by Holland, are useful additions to any entomologist's library, but they mainly deal with American Lepidoptera.

Works without number have been written on the subject of the Lepidoptera inhabiting practically every country in the world. Most of them, however, are profusely illustrated, and, in consequence, expensive.

\section{Coleoptera.}

The remarks we made concerning the two books on Lepidoptera by Stewart apply with equal force to "Common British Beetles," by Hall. He describes every British Beetle figured in our pages.

Fowler's "Coleoptera of the British Islands" is an excellent though expensive work.

The order has received almost as much attention as the Lepidoptera, and there are innumerable works on the Coleoptera of various countries, in addition to books dealing with different families. Water-frequenting species are described in Miall's " Aquatic Insects."

\section{HYMENOPTERA.}

Wheeler's "Ants" is a splendid work, which everyone interested in Formicidce should read and re-read.

"British Hymenoptera Aculeata," by Saunders, gives excellent descriptions of the "stinging" Hymenoptera of these Islands. 
"Humble Bees," by Sladen, may be studied with advantage.

"Bees and Wasps," by Latter, is a sound little book, dealing with some of the commoner British species.

\section{SIPHONAPTERA.}

"The Flea," by Russell, is, so far as we know, the only popular account of these interesting insects.

\section{DiPTERA.}

Hewitt's "House Flies" is a splendid little book dealing with the various species likely to be met with in British households.

Howard's " House Fly" is another good book on the same subject.

Verrall's " British Flies" is a standard but expensive work. It cannot be excelled as a work of reference.

"The Harlequin Fly," by Miall and Hammond, contains a wealth of information, though limited in subject.

Diptera, with aquatic larvæ, are all described in Miall's " Aquatic Insects."

"Tse-Tse Flies," by Austen, is excellent and very well illustrated.

\section{Economic Insects.}

A library could be filled with works on harmful insects.

Doane's "Insects and Disease" is American and good.

Allcock's " Entomology for Medical Men " is a useful work. 
"Insects and Man," by the author of the present volume, describes the relationship of insect to man over a wide field.

Theobald's "Insect Pests of Fruit" gives a concise account, with photographs, of all our important fruit pests.

Gillander's "Forest Entomology " treats in a similar way of forest pests. 


\section{INDEXX}

The principal reforences are shown in Ulack numerals.

Abispa sp., 254

Abraxas grossularia!a, 165

Acalypteratæ, 13, 305, 312

Acanthosoma griseum, 106

Acentropus sp., 169

Acherontia atropos, 52, 151

Achorutes dubius, 59 nivicola, 59

Acilius sulcatus, 187

Acridiidæ, 8, 91, 94 song of, 95

Acrilotheres dux, 94

Acronycta psi, 166 tridens, 166

Aculeata, 12, 224, 236

Adder, flying, 65

Adephaga, 10, 176, 183, 206

Adoxus vitis, 209

Apus marinus, 185 robinii, 185

AEschna cyanea, 75 grandis, 75 heros, 72

Eschnidæ, 8, 74

Agabus bipustulatus, 187 nebulosus, 187

Agdistes sp., 170

Agenia carbonaria, 261

Ageronia sp., 141

Aggressive mimicry, 47, 49, 268

Agrilus angustulus, 203

politus, 203

ruficollis, 203

Agrion sp., 66, 73

Agrionidæ, 8, 73

Agriotes obscurus, 201

Agromyzidæ, 13, 313

Agrotis exclamationis, 166

segetum, 166

spina, 167

Alder fly, 127
Aleurodes brassic $\alpha, 125$ citri, 125

Aleurodidie, 19, 55, 104, 125

Alligator, 128

Alternation of generations, 25, 273

Amara aulica, 184

fulva, 184

Amby, 128

Ammophila campestris, 265 sabulosa, 264

Amphydasis betularia, 46

Ampulicides, 265

Anasa tristis, 107

Anatis ocellata, 195

Anax sp., 75

Andrena argentata, 241

Cuckoos of, 242

fulva, 241

ovina, 241, 242

sp., 221,240

vicina, 241

Andrenidæ, 241

Anergates atratulus, 275

Anobiidæ, 198

Anobium paniceum, 198 striatum, 198

Anomala frischii, 181

Anopheles maculipennis, 287 sp., 291

Anophthalmus sp., 185

Anoplura, 8, 56, 57, 61, 63

Anosia erippus, 144

Anostostoma australiasia, 91

Ant, 29, 56, 113, 123, 185, 188, 191 . $193,200,223,237,268,256$

Amazon, 273

and Aphis Lion, 37

and Coccidæ, 35,37

and Green fly, 35, 36, 37, 38, 39, 272,273

and Lacewing, 37 
Ant, and Lycænidæ, 38

and Microdon, 304, 305

and Plant lice, 35,37

and Paussidæ, 39, 187

Argentine, 274

Black, 273

Garden, 273

Bulldog, 277

Callow, 35

Carpenter, 269

Pennsylvania, 269

castes of, 31

colonies of, 31

Cow, 25s

Driver, 278

eggs of, 34

food of, 34

Fungus, 34, 276

Garden, 273

guests, 39 reason $\mathrm{f} \oplus \mathrm{r}, 39$ tolerated, 41

Harvesting, 34, 275

Hill, 272

Honey, 271

Leaf-cutting, 276

Lion, 18, 130, 297 pits of, 131

Meadow, 273

minim workers of, 32

nuptial flight of, 31

nurses, 33

parasites of, 42

plasticity of, 33,39

polymorphism of, 30,268

pupation of, 35

Queen, 32

Red, 272

senses of, 34

Slave-making, 272,273

Blood-red, 272

solitary, 258

Tree, 269

why, successful, 29

Wood, 272

worker of, 32,33

Anthidium bellicosum, 247

diadema, 247

maniculatum, 247

septendentatum, 247

strigatum, 248

Anthomyia angust ifrons, 312

brassica, 312
Anthomyia cana, 312

Anthomyidæe, 13, 311

Anthonomus grandis, 46, 210 poinorum, 217 signatus, 216

Anthophila, 12, 236, 237

Anthophora, Cuckoos of, 245 personata, 245

pilipes, 245

sp., 21, 22, 244

Anthribidæ, 11, 215

A panteles formosus, 230 glomeratus, 230

A patura iris, 45, 141, 143

A phenogaster arenarius, 275 barbarus, 275 structor, 275

Aphidæ, 9, 18, 19, 29, 36, 37, 38, 39, $55,56,104,123,130,133,195$, $230,233,267,272,273,274,304$ enemies of, 124, 133, 233 fecundity of, 19,123

Aphis Lion, 132 and Ants, 37

Maple, 36

Woolly Apple, 124

A phidius sp., 230

A phodius fimetarius, 179 fossor, 179 rufipes, 179

Aphoruridæ, 8, 59

Apidæ, 12, 244

A pis mellifica, 250

A poda testudo, 158

A poica pallida, 257

A poria cratagi, 148

Apterygota, 7, 8

Aradidæ, 9, 110

Araschnia levana, 28 prorsa, 28

Archiapidæ, 239

Arctia caia, 162 villica, 162

Arctiidæ, 10, 162, 168

Argynnis adippe, 143

agalaia, 143

euphrosyne, 143

lathonia, 143

paphia, 143

selene, 143

Argyromœba trifasciata, 299

Aromia moschata, 214

Asilidæ, 12, 49, 56, 300 


\section{INDEX}

Asphalia flavicornis, 153

Aspidiotus perniciosus, 126

Atelura formicaria, 40

Atemeles, 42, 192

Atherix ibis, 297

egg-laying of, 297

Athous hemorrhoidalis, 201 niger, 201

Atropidæ, 8, 102

Atropos pulsatoria, 102

Atta sp., 276

Attagenus pelleus, 197

Attaphila sp., 41

Attelabus curculionoides,, $\mathbf{1 7}$

Balaninus glandium, 216

nucum, 216

Barynotus obscurus, 217

Batocera sp., 215

Bee, 21, 29, 30, 123, 194, 221, 223, 236,237

and Bee-fly, 299

Bumble, 14, 49, 190, 250

Earth, 251

Stone, 251

Carder, 247, 252

Carpenter, 245

Drone of, 250

fly and Bees, 299

and Locusts, 299

head, 239

Honey, 57, 200, 241, 249, 250

Humble. See Bumble Bee

Leaf-cutter, 248

legs of, 238

Long-horned, 249

Mason, 200, 246, 299

mimicry of, by Robber fiy, 42, 301

Moss Carder, 252

Pointed-tongued, 244

pollen gathering of, 238

prey of Robber flies, 301

Queen, 250, 251

Short Fork-tongued, 239

Short Pjinted-tongued, 241

Sucial, 222, 239, 250

Solitary, 239

swarming of, 31

tongue of, 237

Wool Carder, 247

workers of, 250,251

Beetle, Ambrosia, 218

and Ants, 39
Beetle, Asparagus, 208

Bacon, 196

Black. See Cockroach

Blister, 21, 22, 23, 176, 205

Bloody-nosed, 210

Bombardier, 186, 188

Burying, 191 Black, 191

Cane-borer, Red-necked, 203

Carrion, 191

Roving, 191

Ccllar, 204

Churchyard, 204

Clock, 179

Click, 201 leaping of, 201

Colorado, 210

Dor, 179

Dumble, 179

Dung, 179

EIm-bark, 218 leaf, 114, 211

Flea, 211, 266

Fungus, 194 growing, 218

Golden Apple, 209

Goliath, 175

Ground, 184, 185 violet, 185

June Bug, 181

Leaf, 174, 209, 211

Leather, 196

Luminous, 199, 202

Nimic, 193

Musk, 214

Oil, 22, 176, 205 fecundity of, 205 violet, 203

Pill, 197

Prionid, 213

Rhinoceros, 182

Rose Chafer, 174, 182

Rove, 192 Black, 39

Sacred, 179

Saw-toothed Grain, 194

Scarab, 179

Sexton, 191

Shiclt, 211

Stag, 178, 189, 213

Small, 178

Tiger, 1s3, 184 green, 183 
Beetle, Tiger, Wood, 183

Tortoise, 211, 212

Turnip Blossom, 193

Flea, 211

Wasp, 47, 214

Water, 186

Margined, 187

Silver, 159

breathing of, 190

egg cocoon of, 190

Weevil. See Weevils

Whirligig, 188

Belostomidæ, 9, 116

Bernbex sp., 298

Bembicides, 265

Beneficial insects, 57

Bibionidæ, 12, 282

Bittacomorpha sp., 292

Blaberus giganteus, 86

Black Beetle. See Cockroach

blaps mortisuga, 204

mucronaia, 204

Blastoplaaga sp., 232

Blatta orientalis, 17, 84

Blattidæ, 8, 83, 265

Blissus leucopterus, $10 \mathrm{~S}$

Bloodworm, 289

Bluebottle, 267

Blue Tit, 124

Bogart, 128

Boletophila luminosa, 286

Bombus agrorum, 14, 252, 258

Cuckoos of, 252

lapidarius, 251

muscorum, 14

terrestris, 251

variabilis, 258

venustus, 14, 252

Bombycidx, 10, 151

Bombyliidæ, 12, 298

Bombylius major, 298

Bombyx castrensis, 159

neustria, 159

qucrcue, 159

rubi, 159

Bostrychidx, 11, 54, 174, 197

Brachinus crepitans, 186

Brachonidæ, 12, 56, 229

Brachyporus sp., 91

Brassolidx, I0, 145

Brayla coeca, 314

Braulidæ, 13, 314:

Brenthidæ, 11, 219
Brenthidæ, egg-laying of, 220

Brophos notha, 167 parthenias, 167

Brown Drakes, 77

Bruchidæ, 11, 206

Bruchus chinensis, 206

lentis, 206

obtectus, 260

pisi, 206

Liryophila pcrla, 168

Bug, Abe Lincoln, 106

Ants mimicking, 113

Assassin, 112

Bark, 110

Bed, 57, 105, 112, 113

Giant, 112

stink glands of, 105

Blood-sucking Cone Nose, 112

Cannibal, 112

Chinch, 108

Connoption, 128

Harlequin Cabbage, 106

Lace, 109

Four-lined Leaf, 114

Nealy, 125, 126

Pirate, 112

Squash, 107

Third Party, 106

Buprestidæ, 11, 54, 202, 207, 266

Butterfly, 26, 138

Admiral Red, 141, 142

White, 141, 143

Bluc, 146

Azure, 146

Chalkhill, 140

Clifden, 146

Common, 146

Large, 146

Little, 146

Long-tailed, 146

Mazarine, 146

Silver-studded, 146

Brimstone, 148

Brown Argus, 147

Camberwell Beauty, 143

Clouded Yellow, 148

$$
\text { Pale, } 143
$$

Comma, 142

Copper, Large, 146

Small, 146

Emperor, Purple, 45, 141, 143

Fritillary, Dark Green, 143

Duke of Burgundy, 144 
Butterfly, Fritillary, Glanville, 143 Greasy, 143

Heath, 143

High Biown, 143

Pearl-bordered, 143 Small, 143

Silver-washed, 143

Grayling, 143

Hairstreak Black, 147

Brown, 147

Green, 43, 147

Purple, 147

White Lsttor, 147

Leaf, 43, 141, 143

Marsh Ringlet, 145

Milkweed, 144

Monarch, 144

Orange Tip, 147

Painted Lady, 142

Peacock, 14l, 142

prey of Robber fly, 3 J1

Queen of Spain, 143

Skipper, 149, 150

Checkered, 149

Dingy, 149

Grizzled, 150

Large, 149

Lulworth, 149

Now Small, 149

Pearl, 149

Sinall, 149

Swallow-tail, 52, 143

Tortoiseshell, 141

Large, 142

Small, 141

White Bath, I48

White, Black-veined, 149

Cabbage, 15, 17, 27, 230

Green-veined, 27, 148

Large, 149

small, 148

Wood, 148

Byrrhidæ, 11, 197

Byrrhus pilula, 197

\section{Caddis fly, 25, 76, 134}

carnivorous, 137

Canonym pha typhon, 145

Casterocephalus palcemon, 149

Calandra granaria, 217 oryzae, 217

Caligo eurylochus, 145

Callichroma sp., 214
Calligenia lurideola, 163 miniata, 163

Callimenus sp., 91

Callimorpha dominula, 163

Calliphora erythrocephala, 310 vomitoria, 310

Callotermes sp., 81

Callows, 35

Caloptenus sp., 22

Culopterygidæ, 8, 72, 73

Calopteryx chinensis, 73 splendens, 73 virgo, 72

Calssoma sycophanta, 185

Calypteratæ, 13, 305

Campodeidæ, 8, 60

Camponotides, 269

Camponotus ligniperdus, 269 pennsylvanicus, 269

Camptobrochis grandis, 114

Cantharides, 205

Capnodis sp., 203

Caprification, 232

Capsidæ, 9, 55, 113

Carabidæ, 10, 56, 184, 187

Carabus arvensis, 185 catenulatus, 185 nemoralis, 185 violaceus, 185

Carnivora, 183

Carpets, 164

Carpocapsa juliana, 171 pomonella, 171 saltitans, 171 splendana, 171

Carteria lacca, 126

Caryoborus sp., 206

Cassida equestris, 212 viridis, 212

Cassididæ, 11, 211

Castniidæ, 10, 150

Cataclysta lemnata, 169

Catoxantha bicolor, 203 opulenta, 203

Cecidomyiid $x, 12,20,282,285$

Celaspidia grossa, 213

Cemonus unicolor, 267

Cephalocæma sp., 96

Cephidx, 12, 55, 227

Cephus pygmceus, 227

Cerambycidæ, 11, 54, 214

Ceratitis capitata, 313

Ceratophyllus fasciatus, 281 
Ceratopogon bicolor, 290 bipunctatus, 289

Ceratopsillidæ, 279

Cerceris arenaria, 266 bupresticila, 266 labiata, 268

Cercopidæ, 9, 121, 122

Ceroplastes ceriferus, 126

Cetonia aurata, 182 marginata, 182

Cetoniidæ, 10, 54, 182, 259

Chærocampa elpencr, 152 porcellus, 152

Chalcicodoma muraria, 246, 299

Chalcidid $x, 12,56,231,232,233$

Charcas graminis, 166

Charagia sp., 156

Chartergus chartarius, 257

Cheimatobia brumata, 165

Chermes abietis, 124

Chigœ, 279, 281

Chironomidæ, 12, 77, 289

Chloroperla sp., 77

Chlorops sp., 313

Chloroscelus tenana, 92

Choragus she pphardi, 215

Chrysididæ, 12, 234, 240

Chrysis carulans, 235

bidentata, 235

ignita, 235

Chrysomela banksii, 210

cerealis, 210

gottingensis, 210

limbata, 210

marginalis, 210

rufa, 210

schach, 210

staphylea, 210

Chrysomelidæ, 11, 54, 209

Chrysomyia macellaria, 310 polita, 267

Chrysopa vulgaris, 133 egg8 of, 133

Chrysopidæ, 9, 56, 133

Chrysops sp., 298

Cicada, 117, 123, 262, 266

periodical, 119

septendecim, 119

song of, 118

vocal organs of, 115

Cicadid $x, 9,55,117$

Cicindela campestris, 1S3 sylvatica, 183
Cicindelid $x, 10,56,183$

Cilix glaucata, 158

Cimex lectularius, 113

Cimicidæ, 9, 57, 113

Cistelidæ, 11, 204

Classification, 5

Clavicornia, 177

Claviger testaceus, 192

Clearwings. See Moths

Clegg, 297

Cleonus sulcirostris, 218

Cleptes sp., 236

Cleridæ, 11, 200

Climacia sp., 132

Clipper, 128

Clythra sp., 40

quadripunctata, 208

Clythridæ, 11, 208

Clytus arietis, 48

sp., 214

Cnethocampa processionea, 151

Coccidæ, 9, 55, 56, 58, 104, 105, 125,273

and ants, 37

Coccinella bi-punctata, 185

7-punctata, 195

10-punctata, 195

Coccinellidæ, 11, 56, 195

Coccus cacti, 126 mannifera, 126

Cochineal, 58, 126

Cockchafer, 180, 181

Cockroach, 17, 18, 83, 112, 113, 230

American, 84

Colioxys quadri-dentata, 249

Coleoptera, 10, 17, 39, 52, 55, 56, 139, $173,220,233$

Colias edusa, 148 hyale, 148

Collembola, 8, 18, 59

Culletes daviesanus, 241 succincta, 240

Colouring, 42

Colours, protective, 42,44 warning, 47

Colymbetes fuscus, 187

Coniopterygida, 9, 130

Conopidx, 12, 302

Conopinæ, 302

Conorhinus sanguisuga, 112

Conotrachelus nenu phar, 217

Copridæ, 10, 179, 180

Copris lunarie, 179 


\section{INDEX}

Cordulegaster annulatus, 74

Cordulegasteridæ, 8, 74

Cordulidæ, 8, 75

Coreidæ, 9, 106

Coremia hirtipes, 214

Corixa femorata, 117 eggs of, 117 geoffroyi, 117 mercenaria, 117

Corixidæ, 9, 117

Corydalis cornuta, 128

Corydia petiverana, 86

Corynetes caeruleus, 200

Coscinocera hercules, 150

Cosmosoma, sp., 214

Cossidæ, 10, 53, 156

Cossus ligniperda, 155

Cotton stainers, 55, 108 lesser, 108, 109

Courtship of Swift Moth, 157

Crabro cetratus, 267

clypeatus, 267

cribrarius, 267

dimidiatus, 267

gonager, 267

interruptus, 267

leucostomus, 267

palmarius, 267

peltarius, 267

podagricus, 267

quadrimaculatus, 267

scutellatus, 267

sp., 231

westmoeli, 267

Crabronides, 267

Crambus sp., 163

Crawlers, 128

Creepers, 77

Cremastogaster sp., 276

Cricket, 40, 41, 83, 90, 111

Field, 90

House, 90

Mole, 90

singing of, 93

Tree, 90, 91

Crioceridæ, 11, 208, 211, 212

Crioceris asperagi, 208 merdigera, 208

Crock, 128

Cryptocephalidæ, 11, 209

Cryptocephalus sericeus, 209

Cryptocerata, 105, 114

Cryptophagidæ, 11, 194
Ctenocephalus canis, 279 felis, 279

Cuckoo fly, 234

Cuckoo of Andrena, 242

of Anthophora, 245

of Bombus, 252

of Halictus, 243

of Megachile, 249

of Osmia, 248

Spit insect, 121, 122

Culex sp., 214

fatigans, 287

pipiens, 287

Culicidæ, 12, 56, 286

Curculionidæ, 11, 54, 216

Cursoria, 83

Cutworms, 53

Cyclorrhapha Aschiza, 13, 302 sohizophora, 13, 305

Cymatophorid $x, 10$

Cynipidæ, 12, 25, 55, 58, 233

Cynips sp., 267

Cynomyia mortuorum, 309

Cyphocrania semirubra, 89

Cyrtophyllum crepitans, 93

Daddy-long-legs, 291

Danaidæ, 10, 144

Dascillidæ, 11, 200

Dascillus cervinus, 201

Dasychira pudibunda, 161 rossi, 162

Dasylis sp., 49

Dasypoda hirtipes, 244

Day fly, 77

Death watch, 198, 200

Deilephila euphorbia, 151 galii, 151

Deinacrida sp., 91

Demoiselle, 72

Dermatobia sp., 306

Dermatophilus penetrans, 281

Dermestes lardarius, 197

Dermestidæ, 11, 196

Deromyia annulata, 49

Devil's Coach-horse, 192

Darning-needle, 65

Diactor bilineatus, 107

Diapheromera femorata. 89

Dicranura vinula, 152

Dictyophorus reticulatus, 97

Dimorphism, 43, 140

seasonal, 26,140 
Diopsidx, 13, 313

Dioxys cincta, 247

Diploptera, 12, 236, 253

Diptera, 12, 17, 52, 54, 55, 56, 139, $193,231,233,265,282$

Disease and flies, 55

Division of labour, 30

Dixa sp., 291

Dixidæ, 12, 291

Dobson, 127, 128 Ameriean, 128

Dolichoderides, 274

Dolium diabolicum, 50

Donacea crassipes, 207 semicuprea, 207

Donacidæ, 11, 207

Dorcus parallelopipedus, 178

Dorylides, 277

Dorylus sp., 277

Doryophora punctatissima, 210

Dragon, 128

Dragon fly, 18, 65, 253 capture of prey, 66 emergence from pupa, 69 pairing of, 66 migration of, 72 prey of Robber flies, 301

Drepana falcatoria, 158 lacertinaria, 157

Drepanidæ, 10, 157

Drosophilidæ, 13, 313

Dry season forms, 26

Dynastes hercules, 182

Dynastidæ, 10, 54, 181, 182

Dysdercus sp., 55, 108 suturellus, 108

Dytiscidæ, 10, 186, 188

Dytiscus marginalis, 187 punctulatus, 187

Earwig, 61, 98

Echinophthirius, sp., 64

Echiton sp., 277

Economic entomology, 51

Egg-laying of Brenthidæ, 220

Elateridx, 11, 54, 201

Elater-sanguinolentus, 201

Elephantiasis, 287

Elis 4-notata, 260

Embia savignyi, 100

Embiidæ, 8, 100

Embioptera, 8, 100

Emesidæ, 112
Empidx, 12

Encyrtus sp., 233

Endopterygota, 7, 9, 127

Endromidie, 10, 159

Endromis versicolor, 159

Entomobryidx, 8, 59

Epeolus variegatus, 241

Ephemera vulgata, 77

Ephercoridæ, 8, 77, 79

Ephemeroptera, 8, 18, 77

Ephestia kühniella, 168

Epicauta sp., 205 vittata, 22,23

Ephippittya triginguttata, 93

Epilachna sp., 195

Equal wings, 78

Erastria scitula, 167

Ericerus pela, 126

Eriocampoides linacina, 226

Eristalis tenax, 284, 303, 304

Erycinido, 10, 144

Eucera longicornis, 249

Euchelia jacobœc, 163

Euchloë cardamines, 147

Euglossa sp., 246

Eumenes coarctata, 253 fraterna, 235 pomiformis, 254

Eumenidæ, 12, 253

Eumolpidæ, 11, 209

Eumol pus fulgidus, 209

Euplectrus comstockii, 232

Euplexoptera, 8, 18, 98

Euproctis chrysorrhcea, 162

Eupterotidæ, 10, 151

Euthrips citri, 103 pyri, 103

Evania appendigaster, 230

Evaniidx, 12, 56, 85, 230

Exopterygota, 7, 8, 61

Fanus jaculator, 231

Fannia canicularis, 16

Fever, Phlebotomus, 291

Recurrent, 57, 113

Sand fly, 291

Three-day, 57, 291

Yellow, 56, 282, 287

Filaria, 237

Fire Brat, 61

Firefly, 202

Fishfly, 127

Flata sp., 43 
Flatidæ, 120

Flea, 279

Bat, 279, 280, 281

Cat, 279

Chigœ, 279, 281

Dog, 279

Human, 279, 280, 281

Mouse, $2 \mathrm{s0}$ leaping powers of, 279

Plague, 281

Rat, 281

structure of, 280

Turnip, 211

Flipflap, 128

Fly and disease, 282

Armed, 293

Bat, 314

Bee, 298

and Bees, 299

and Locusts, 299

Big-eyed, 302

Black, 293

Blow, 309, 310

Bluebottle, 310

Bot., 284, 305

Emasculating, 306

Horse, 306

Sheep, 305, 307

Breeze, 297

Cabbage root, 312

Celery, 282

Chameleon, 296

Cheese, 312

Crane, 282, 291

Dance, 301 webs of, 301

Deer, 297

Dragon. See Dragonfly

Drone, 284, 304

Dung, 312

Flesh, 19, 309

Forest, 314

Frit, 282, 313

Fruit, 313

Lesser, 313

Mediterranean, 313

Gad, 297

Gall, 283, 285

Green. See Greenfly

Greenbottle, 310

Harlequin, 289

Hessian, 285

Horn, 310
Fly, Horse, 297, 314

House, 13, 14, 15, 16, 57, $284,298,303,308,310$, 311

Lesser, 16

Hover, 303

March, 293

May. See Mayfly

Moth, 290, 293

Narcissus, 304

Onion, 282, 312

Ox Warble, 306, 307

Pangonia, 298

Robber, 49, 296, 300 mimicking Bees, 49, 301 prey of, 301

sand, 290,293

Screwworm, 310

sexes of, 283

Sheep Bot., 19

Sheep Nasal. See Sheep bot. fly tick, 314

Snipe, 296

Soldier, 295

Stable, 310

Stalk-eyed, 313

Syrphid, 124

Thick-headed, 302

Tse-tse, 19, 57, 310 name of, 311

Typhoid, 14

Window, 298

Flying adder, 65

Forester, 154

Forficula auricularia, 98

Forficulidæ, 8, 98

Formica canicularia, 272

fusca, 272, 273 auricularia, 273

rufa, 40, 272, 275

sanguinea, 272

Formicidæ, 12, 79, 237, 268

Formicoxenus nitidula, 275

Fossores, 12, 237, 257

Fringe wings, 102

Fritillary. See Butterfly

Frog hoppers, 121

Fulgoridæ, 9, 43, 120

Fungus gnats, 286

Galeruca tenaceti, 211

Galerucella luteola, 114, 211

Galerucidæ, 11, 54, 211 
Grl!, 5R

Bedeguar, 234

Currant, 25

fly, 25, 223, 233

formation of, 234

Gnat. See Gall fly

Oak-apple, 26

Root, 26

Spangle, 25

Galleria sp., 170

Gastrophilus equi, 306

Gcometers, 43, 164

Geometridæ, 10, 53, 163

Geotrupes spiniger, 180 stercorarius, 179 sylvaticus, 180

Gerris sp., 111

Glossina sp., 19, 310 morsitans, 311 palpalis, 311

Glow-worm, 199 New Zealand, 286

Glyptus, mimic of Termites, 185 sculptilis, 185

Gnat, 110, 267, 286

Buffalo, 293

Fungus, 286

Gall. See Gall fy

Water, 110

Gnophria quadra, 163

Gnorimus nobilis, 182

Goggle goy, 128

Golden eye, 133

Gomphidæ, 8, 74, 75

Gomphus vastus, 74

Gonepteryx rhamni, 148

Gongylus gongyloides, 50

Grasshopper, 92

Great Green, 82

Long-horned, 91, 92

prey of Robber flies, 103

Short-horned, 94

Grayling, 145

Greenbottle, 310

Green Drake, 77

fly, 35, 104, 123, 235, 304

and Ants, 35, 36

and Ladybirds, 124, 195

enemies of, 124

fecundity of, 19, 123 siphons of, 37

Growth, 15

Gryllidæ, 8, 90, 95
Gryllotalpa vulgaris, 90

Gryllus campestris, 90

domesticus, 90

Gymnocerata, 105

Gyrinidæ, 11, 188

Gyrinus natator, 188

Gyropidæ, 8, 61

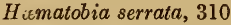

$H$ i:matomyza elephantis, 64

Hcmatopinus asini, 64

Homatopota sp., 298

Hcmonia curtisi, 207

Hairstreak. See Butterfly

Halictus, Cuckoos of, 243

lineolatus, 243

maculatus, 243

malachurus, 243

morio, 243

quadricinctus, 243

sexcinctus, 243

sp. 221,266

Halobates, sp., 111

Haltica sp., 211 tabida, 266

Halticidæ, 11, 54, 210

Harpalus œneas, 184 latus, 184 ruficornis, 184

Harpax ocellaria, 87

Heliconiidæ, 10, 145

Heliconius erato, 145

Heliopathes gibbus, 204

Hell devil, 128 diver, $12 \mathrm{~S}$

Hellgrammite, 127

Helopeltis, sp., 114

Hemerobiidæ, 9, 132, 133

Hemiptera, 63, 105

Henicocephalidæ, 9, 111

Hepialidæ, 10, 156

Hepialus humuli, 156

hectus, 156

velleida, 156

Hesperia actœon, 149

comma, 149

lineola, 149

sylvanus, 149

thaumas, 149

Hesperiidæ, 10, 149

Hetærina, 73

Heterocera, 10, 139, 149, 150

Heterogyna, 12 
Heteromcra, 11, 177, 203

Heteroptera, 9, 104, 105

Hibernation, 26

II imatidium latreilli, 213

II ippobosca equina, 314

Hippoboscidæ, 13, 57, 314

Hippodamia 13-punctata, 195

Hispidæ, 11, 211

Hister bimacnlatus, 193 cadaverinus, 193 unicolor, 193

Histeridæ, 11, 39, 192 and ants, 39

Ho Jack, 128

Hololepta sp., 193

Homoptera, 9, 104, 117, 302

Honey dew, 36, 37, 38 how obtained by ants, 38

IIoplia philanthus, 181

Hornet, 48, 192

Horse stinger, 65

Hybernia defoliaria, 165

IIybocampa milhauscri, 153

IIydrocampa nympleata, 169 stagnata, 169

IIydrocyphon defexicollis, 201

IIydrometra stagnorum, 110

Hydrometridæ, 9, 110, 111

Hydrophilidx, 11, 189

Hydrophilus piceus, 189

Hydropsychidæ, 9, 137

Hydroptilidæ, 9, 137

Hylastes ater, 219 palliatus, 219

IIylatoma rose, 225

Hylemyia cepetorum, 312 strigosa, 312

Hylobius abietis, 216

Hylurgus piniperda, 219

Hymenoptera, $11,17,52,55,77,81$, $88,122,124,126,139,221,222,223$, 302,303

Hymenopus bicornis, 50

Hypera punctata, 218

Hypermetamorphosis, 21, 22

IIyphydrus ovatus, 187

IIypolerma bovis, 306 lineata, 306

IIyponsmeuta padella, 172

Hypsidæ, 10, 152

Icerya purchasi, 126, 196

Ichnoumon flies, 228
Iclıneumonidæe, 12, 56, 228

Idclothrips spectrum, 102

Ilybius ater, 187 fuliginosus, 187

Ino globularius, 154

Insects and disease, 51,56 definition of, 6

Ips quadriguttata, 193

Iridomyrmex humilis, 274

Ischnomyrmex cockerelli, 33

Isoptera, 8, 18, 52, 78

Isosoma, sp., 231

Japygidæ, 8, 60

Jassidæ, 9, 55, 122, 302

Julodis cirrosa, 203

Jumping beans, 171

June bug, 181

Kakothrips robustus, 103

Kallima sp., 43, 141, 143

Katydid, 92

Angular-winged, 93

Kingfisher, 72

Komarovia victoriosa, 259

Lavia minor, 99

Labrus gibbus, 184

Lac insect, 58, 126

Lacewing, 124, 133 and Ants, 37, 124

Lacon murinus, 201

Ladybird, 124, 126, 174, 195

and Greenfly, 124, 195

and scale insects, 126, 196

2-spotted, 195

7-spotted, 195

10-spotted, 195

13-spotted, 195

Lamellicornia, 10, 176, 177, 181, 259

parasites of, 259

Lamiidæ, 11, 54, 173, 214

Lampyrides, 199

Lampyris noctiluca, 199

Lasiocam pa quercifolia, 159

Lasiocampidæ, 10, 158

Lasius flavus, 272, 273

fuliginosus, 39,273

niger, 273

Leaf insect, $43,83,88$

miner, 53, 55, 172

roller, 53, 171

Leaping of Click Beetle, 201 of flea, 279 
Lecanium olea, 167

Lepidocyrtus americanus, 59

Lepidoptera, $9,17,26,27,43,44,46$, $52,53,54,120,138,176,196,224$, $225,229,231,284,285,295,315$

Lepisma domestica, 61 saccharinum, 61

Lepismatidæ, 8,61

Leprosy, 113

Leptidæ, 12, 296

Leptinidæ, 11, 190

Leptinotarsa decemlineata, 210

Leptinus testaceus, 190

Leptis scolopacea, 296

Leptoceridæ, 9, 137

Leptoglossus phyllopus, 107

Leptopsylla musculi, 280

Lestes sp., 73

Leto venus, 156

Leucophasia sinapis, 148

Leucospis gigas, 246 sp., 231

Libellula depressa, 66, 75 quadrimaculata, 75

Libcllulidæ, 8, 75

Limacodidæ, 10, 158

Limnetis sibylla, 143

Limnophilidæ, 9, 136

Limnophilus flavicornis, 136 rhombicus, 136

Liometopum microcephalum, 274

Liophlous nubilis, 217

Liotheidæ, 8, 61

Lipara lucens, 267

Lithargus bifasciatus, 194

Locust, 22, 83, 91, 200 and Bee flies, 299 life history of, 93,97 migration of, 96 parasites of, 22,260 Rocky Mountain, 97 seventeen year, 18, 81 song of, 92

Locusta viridissima, 92

Locustidx, 8, 91, 95, 264

Lomechusa, 42, 192

Looper, 164

Lopaphus cocophages, 88

Lophopteryx camelina, 153

Lophyrus pini, 225

Louse, Bird, 61

Body, 63

Book, 100
Louse, Crab, 64

Elephant, 64

Head, 63

Horse, 64

Human, 63

Jumping Plant, 104

Seal, 64

True, 61,63

Lucanide, 10, 54, 178, 181, 213

Lucanus cervus, 178

Lucilia coesar, 31 .

Lycona agon, 146

argiolus, 146

arion, 146

astrarche, 147

bellargus, 146

botica, 146

corydon, 146

icarus, 146

minima, 14

semiargus, 146

Lycænidæ, 10, 38, 145

and ants, 58

Lycus sp., 200

Lygæidæ, 9, 107

Lymantriidæ, 10, 53, 160

Macharota guttigcra, 122

Machilidæ, 8, 61

Machilis maritima, 61

Macrodontia sp., 213

Macroglossa, fuciformis, 152 stellarum, 152

Macropathus filipes, 91

Macropus longimanus, 215

Maggot, Rat-tailed, 24, 284, 204

Malacodermidæ, 11, 199

Malaria, 56, 282, 287

Mallophaga, 8, 18, 61

Mallophora sp., 49

Mamestra brassica, 166

Manna, 126

Mantidæ, 8, 50, 86, 112, 129

Mantis, habits of, 86 parasite of, 88 praying, 86 religiosa, 86

Mantispidæ, 9, 129

Mayetiola destructor, 285

May fly, 77, 111, 235

Mcalworm, 203, 204

Miastogaster lucretia, 65

Megachile albocincta, 249 
Megachile, circumcincta, 249

Cuckoos of, 249

Megastigmus sp., 231

Melanoplus spretus, 97

II elanotus rufipes, 201

Melecta armata, 245 luctuos $d, 245$

Meligethes øneus, 193

Melitcea athalia, 143 auricoma, 143 cinxia, 143

Mele proscarabous, 22, 205 violaceus, 205

Meloidæ, 11, 21, 22, 176, 205

Melolontha vulgaris, 180

Melolonthidæ, 10, 54, 180, 181, 259

Melophagus ovinus, 314

Melophorus inflatus, 271

Membracidæ, 9, 121

Menopon pallidum, 62

Merodon equestris, 304

Metamorphosis, 15

Metapodius femoratus, 107

Methoca ichneumonides, 259

Miastor sp., 20

Microcentrum retinervis, 93

Microdon and ants, 304, 305

Midge, 111, 223

Horned, 290

Splay-footed, 290

Migration of Dragon flies, 72

of Locusts, 96

of Nymphalidæ, 142

of Sciara militaris, 286

Mimesides, 266

Mimic battles of Pompilids, 262

Mimicry, 47, 141

aggressive, 47, 49, 268

of flowers, $44,50,87$

in Reduviidæ, 112

protective, 47

Minim workers of ants, 32

Monodontomerus nitidus, 246

Monohanmus sp., 215

Monomorium pharaonis, 275

Morphidæ, 10, 145

Morpho sp., 145

Mosquito, 282, 284, 286, 290

and disease, 287

eggs of, 287

common, 287

pupæ of, 289

spotted winged, 287
Mosquito, Tiger, 287

yellow fover, 287

Moth, 26, 138, 150

Antler, 51, 166

Atlas, 150

Bagworm, 154

life history of, 154

Bee, 53, 170

Black Arches, 161

Brindled Beauty, pale, 165

brown-tail, 162

Buff Arches, 153

Buff Tip, 153

Bugong, 167

Burnet, 154, 163

6-spotted, 154

Cabbage, 166

Carpet, 298

China Marks, 169 brown, 169 small, 169

Chocolate Tip, 153

Cinnabar, 163

Clearwing, currant, 154 Hornet, 48, 154

Clothes, 53, 171

Codling, 171

Currant, 165

Dart, 166

December, 159

Dragon of Old Sepp., 153

Drinker, 158

Early Thorn, 165

Emperor, 150

Ermine, Buff, 163

small, 172

white, 163

Flour, 168

Footman, 163 4-spotted, 163

Rosy, 163

Forester, 154

Fox, 159

Ghost, 156

Gipsy, 160, 161, 185

Goat, 155

Gold Spot, 167 tail, 161, 162

Gooseberry, 165

Grass, 168

Hawk, 151

Bedstraw, 151

Bee, 152 
Moth, Hawk, Convolvulus, 161 Death's-head, 52, 151 Elephant, 152 Eyed, 152 Humming bird, 152 Poplar, 152 Privet, 44, 151 Spurge, 151

Hart and Dart, 166

Hoary Grey, 168

Hook Tip, 157

Hop dog, 161 Pebble, $15 \mathrm{~s}$

Kentish Glory, 159

Lackey, 159 Ground, 159

Lappet, 159

Lobster, 153

Magpie, 165

Marbled Beauty, 168

Meal, 168

Mottled Umber, 165

Muslin, 163

Nun, 160, 161

Oak Eggar, 159

Miner, 172

Peach blossom, 153

Peppered, 46

Pine Beauty, 44

Plume, 170

prey of Robber flics, 301

Processionary, 29, 151185

Prominent, Coxcomb, 153

Iron, 153

Pebble, 153

Swallow, 153

Puss, 152

Swift, 156 courtship of, 157

gold, 156

Northern, 157

Tiger, buff, 163 cream spot, 162 Garden, 162 ruby, 162 scarlet, 163

Tineid, 23

Tortrix, green, 171

Turnip, 166

Tussock, pale, 161, 162

Underwing, orange, 167 used as food, 167

Vapourcr, 25, 160
Moth, Vapourer, life history of, 160 Winter, 165

Wood Leopard, 156

Woollen, 172

Yellow-horned, 153

Yucca, 23, 24

Moulting, 18

Murgantia histrionica, 106

Musca domestica, 13, 14, 310

Muscidæ, 13, 56, 57, 309, 310, 311

Mutilla europaa, 258

Mutillidæ, 12, 258, 259

Mycetophagidæ, 11, 194

Mycetophagus quadripustulatus, 194

Mycetophilidæ, 12, 286

Myiatropa florea, 303

Myopinæ, 302

Myrmecocyrtus hortiderrum, 271 melliger, 271

Myrmecia sp., 277

Myrmecophana fallax, 92

Myrmecophila sp., 40, 41

Myrmedonia funesta, 39, 192

humeralis, 39, 194

Myrmelionidx, 9, 130, 132

Myrmica rubra, 275

Myrmicides, 275

Nabis lativentris, 113

Nagana, 310

Names, popular, 14 priority of, 14

Nanosella fungi, 174

Nasuti, 82

Necrobia ruficollis, 200 rufipes, 200

Necrodes littoralis, 191

Necrophorus humator, 191 mortuorum, 191 ruspator, 191 vespillo, 191

Nematus gallicola, 225 ribesii, 225 salicis, ci erere ,225 ventricosus, 225

Nemeobius lucina, 144

Nemeophila russula, 163

Nepa cinerea, 115

Nepidæ, 9, 114

Nepticula ruficapitella, 172

Nest of Bumble Bee, 251 of Chalcidoma, 246 of Dasypoda, 244 
Nest of Eumenes, 253 of Loaf-cutter Bee, 249 of Trce Ant, 270

Neuroptera, 127

Neuroterus lenticularis, 25

Nezara sp., 106

Nisoniades syrichtilus malvin, 150 tagos, 150

Nitidula bipustulata, 193

Nitidulidæ, 11, 193

Nits, 63

Noctuidæ, 10, 53, 153, 165

Nomada lathburiana, 242

Notodonta dicti a, 153 dromedarius, 153 ziczac, 153

Notodontidæ, 10, 152, 153

Notonecta glauca, 116

Notonectidæ, 9, 116, 117

Novius cardinalis, 126, 196

Nudaria mundana, 163

Nycterbiidæ, 13, 314.

Nymphalidæ, 10, 141, 149

Oak apple, 26

Ocneria dispar, 160, 161

Ocypus olens, 192

Odonata, $8,18,55,56,65$

Odonestis potatoria, 158

Odynerus callosus, 254 parietum, 235 reniformis, 235,254 spinipes, 235, 254

EEcophylla smaragdina, 269 nesting habits of, 270

Estridæ, 13, 57, 305

Estrus ovis, 19, 306, 307

Oligarces, 20

Oligoneuria rhenana, 78

Onthophagus fracticornis, 179

Orectochilus sp., 189

Orgyia antiq:ia, 160

Ornithoptera sp., 148

Ortalidæ, 13, 312

Orthetrum sp., 75

Orthoptera, 8, 18, 52, 54, 82, 264

Orthorrhapha Brachycera, 12, 295 Nemocera, 12, 284, 285

Oryctes naseicornis, 182 rhinoceros, 182

Oscinidæ, 13, 313

Oscinus frit., 313

Osmia bicolor, 247
Osmia bicolor, cuckoos of, 248

leucomelana, 247

nesting habits of, 247

rufa, 247

sp., $246,247,261$

tridentata, 247

Osmylus fulvicephalus, 132

Otiorrhynchus tenebricosus, 217

Oxybelus uniglumis, 49, 268

Oxycarenus sp., 108, 109

Oxythyrea stictica, 182

Pædogenesis, 20

Palustra sp., 151

Panchlora sp., 86

Pangonia sp., 298

Panolis piniperda, 44

Papilio machaon, 52, 148

Papilionidæ, 10, 148

Papiriidæ, 8, 60

Parasites, 21, 57, 61, 62, 113, 222, 231, 232, 233, 235, 236, 246, 256, 259

Parasitica, 12, 224, 228

Parasitic flies, 306, 307, 308, 314

Parasitism, 20

Parthenogenesis, 19

Passalidæ, 10, 177, 179 song of, 178

Pattern, types of, 48

Paussidæ, 11, 39, 187 and ants, 39,187

Peach scale, 167

Pear Slug, 226

Pedicinus sp., 64

Pediculidæ, 8,63

Pediculus capitis, 63 vestimenti, 63

Pegomyia inanis, 256

Pela wax, 58

Pellagra, 295

Pelobiidæ, 10, 186

Pelobius tardus, 186

Peinphredon lugubris, 267

Pentatomidæ, 9, 55, 105, 107

Pepsis sp., 113, 261, 262

Perga lewisii, 226 care of young, 227

Pericallia bilunaria, 165

Periplaneta americana, 84

Perla bicaudata, 76

Perliidæ, 8, 76, 79

Petiolata, 12, 224, 225, 223

Petrognatha gigas, 215 
Phalera curtula, 153 bucephala, 153

Phasgonuridæ, 92

Phasmidæ, 8, 88

Phenax auricoma, 120 symbiosis of, 120

Phibalocera pythonicus, 90

Phigalia pedaria, 165

Philanus spumarius, 122

Philanthides, 266

Philanthus triangulum, 266

Philopteridæ, 8, 62

Phlebotomus pappataci, 290

Phrygania grandis, 136

Phryganeidæ, 9, 136

Phthirius inguinalis, 64

Phyllaceus integer, 228

Phyllium crurifolium, 43,90

Phyllobius calcaratus, 217

Phyllomor pha laciniata, 107

Phyllopertha horticola, 181

Phyllotreta sp., 211

Phylloxera vastatrix, 124

Phytophaga, 11, 177, 206

Pieridæ, 10, 53, 147

Pieris brassica, 15, 148 bryonia, 27

daplidice, 148

napi, 27, 148

rapos, 27148

Pigeon Tremex, 227

Pimpla fairmairii, 229 rufata, 229

Piophila casei, 312

Pipunculidæ, 13, 302

Pipunculus fuscipes, 302

Pityogenes bidentatus, 219

Plagiolepis sp., 271

Plague, 57, 281

Planipennia, 9, 17, 55, 56, 127

Plant lice and ants, 37

Platypsillidæ, 11, 190

Platyirhinus latirostris, 215

Plea minutissima, 117

Plecoptera, 8, 18, 76

Plectrocnemia, decoys of, 139

Plusia festuca, 167

Podagrion pachymerus, 232

Poduridæ, 8, 59

Pocilocampa populi, 159

Poscilocapsus lineatus, 114

Pogonomyrmex barbatus, 275

Polistes metricus, 49
Polistes sp., 221, 257

Pollen baskets, 239

Polybia sp., 257

Polyergus rufescens, 273

Polygnotus sp., 233

Polymorpha, 11, 176, 177, 187

Polymorphism, 30, 268

Polyommatus dispar., 146 phl ceas, 146

Polyrachis argentea, 271 mayri, 272 nidificans, 272 rastella, 272

Pompilidæ, 261

Pompilus plumbeus, 263 rufipes, 263 viaticus, 263

Ponera contracta, 277 punctatissima, 277

Ponerides, 277

Porphyraspis tristis, 212

Porthesia similis, 161

Pria dulcamera, 193

Priocnemis bicolor, 262

Prionidæ, 11, 175, 213

Prionis coriarius, 213

Proconia undata, 122

Proctotrypidæ, 12, 56, 232

Pronuba yuccasella, 23

Prosopis signata, 240

Protection of eggs in Clythridæ, 209

Protective colouring, 42 mimicry, 47

Protura, 8

Psammocharidæ, 12, 261

Pselapidæ, 11, 39, 191 and ants, 39, 192

Psen concolor, 267

Pseudococcus citri, 126

Pseudomyrma bicolor, 276

Psilura monacha, 160, 161

Psithyrus sp., 252

Psocidæ, 8, 29, 100

Psocoptera, 8, 100

Psocus bipunctatus, 101 citricola, 102 venosus, 101

Psychida, 10, 154

Psychodidæ, 12, 57, 290

Psylla, Pear tree, 123 pyricola, 123

Psyllidæ, 9, 55, 104, 123, 267

Pterochroza ocellata, 92 


\section{INDEX}

Pterophoridæ, 10, 170

Pterostichus cupreus, 185

madidus, 185

picimanus, 185

striola, 185

Ptinidæ, 11, 198

Ptinus fur, 198

Ptychoptera sp., 292

Ptyelus gondoti, 122

"Pugs," 164

Pulex irritans, 279, 281

Pulicidæ, 12, 279

Pupiparia, 13, 19, 20, 314

Pyralidie, 10, 54, 168

Pyralis farinalis, 168

Pyrophorus noctilucus, 202

Pyrrhocoridæ, 9, 108, 109

Pyrrhocorus apterus, 108

\section{Ranatralinearis, 115}

Rat-tailed Maggot, 24, 284, 304

Reduvius personatus, 112,113

Reduviidæ, 9, 56, 105, 111

Reduviids, mimicry in, 112

Rhamnatocerus biguttatus, 94

Rhaphididæ, 9, 129

Rhipiphorus paradoxus, 256

Rhizotrogus solstitialis, 181

Rhodites rosø, 234

Rhopalocera, 10, 139, 141

Rhyacophilidæ, 9, 137

Rhynchites betul $\infty, 217$

Rhynchium brunneum, 255

Rhynchophora, 11, 177, 206, 215

Rhynchophorus palmarum, 218

Rhynchota, 8, 18, 52, 55, 56, 57, 104, 221

Rhyssa persuasoria, 229

Robin's Pincushion, 234

Rutelidæ, 10, 54, 181

Sagria buqueti, 208 seraphica, 208 splendida, 208

Sagridæ, 11, 207

Saissetia olea, 126

Saltatoria, 83

Saperda carcharias, 214

Sapyga clavicornis, 260

5-punctata, 260

Sapygidæ, 12, 260

Sarcophaga, 19

Sarcophagid $æ, 13,57,309,310$
Sarcophila carnaria, 309

magnifica, 309

Sarcopsillidæ, 279

Saropoda bimaculata, 249

Saturnia pavonia, 150

Saturniidx, 10, 150

Satyridæ, 10, 145

Satyrus semele, 145

Sawfly, 29, 236

Currant, 225

Gooseberry, 225

egg-laying of, 225

Scale Insects, 35, 104, 125, 130

and Ants, 35

and Ladybirds, 126

Black, 126

Cottony cushion, 125, 196

Peach, 167

San José, 126

Scarabou.s sacer, 179

Scatophagidæ, 13, 312

Sceliphron loetus, 265

madraspatanus, 265

spirifex, 265

Scenopinidæ, 12, 298

Scenopinus fenestralis, 298

Schizodactylus monstrosus, 90

Schizoneura lanigera, 124

Sciara militaris, 286 migration of, 286

Scolia atrata, 260

bifasciata, 259

interrupta, 259

Scoliidx, 12, 259, 260

Scolytidæ, 11, 54, 218

Scolytus destructor, 219

Scoparia dubitalis, 168

Scutellista cyanea, 126

Se isonal dimorphism, 26, 140

Somi-loopers, 167

Sepsidæ, 13, 312

Serica brunnea, 181

Sericaria mori, 151

Sericostomatidæ, 9, 137

Serricornia, 177

Sesia tipuliformis, 154

Sesiidæ, 10, 53, 154

Sessiliventres, 12, 224, 225

Sheep Tick, 314

Shellac, 58

"Shiner," 188

Sialidæ, 9, 127

Sialis lutaria, 127 
Sigara minutissima, 117

Silkworm, 57, 140, 151, 309

Silpha atrata, 191

lovigata, 191

opaca, 191

quadripunctata, 151

rugosa, 191

sinuata, 191

thoracica, 191

Silphidæ, 11, 120

Silver fish, 40,61

Simulidæ, 12, 57, 293

Simulium clegans, 295 sericeum, 295

Sinodendron cylindricum, 179

Siphonoptera, 12, 17, 56, 57, 273

Siphunculata, 63

Sirex gigas, 227 noctilio, 227

Siricidæ, 12, 55, 227

Sisyra sp., 132

Sitaris humeralis, 21, 22

Skipjacks, 201

Sleeping sickness, 57, 282, 310, 311

Smerinthus ocellatus, 152 populi, 152

Smynthuridæ, 8, 60

Smynthurus lutcus, 60 courtship of,

Snake doctor, 128 feeder, 65

fly, 129

Social habits, 29

Song of Cricket, 92

of Locust, 92 of Passalidæ, 178

Spathogaster baccarum, 26

Sphøra acaroides, 174

Sphæridæ, 174

Sphecius speciosus, 266

Sphecodes gibbus, 244

rubicundus, 243

subquadratus, 243

Sphegidæ, 12, 263

Sphegides, 263, 265

Sphex, nest of, 264

Sphingide, 10, 151

Sphinx convolvuli, 151

ligustri, 44, 151

Spilosoma fuliginosa, 162

lubricipeda, 163

menthastri, 163

Springtails, 53
Stauropus fagi, 153

Staphylinidæ, 11, 39, 192

and Ants, 39

Stegomyia fasciata, 287

Stelis minuta, 248

nasuta, 246, 243

signata, 248

Stenopelmatus sp., 93

Stenophylax sp., 137

Sternocera castanea, 203

Stick Insects, 43, 83, 88, 112

Stink fly, 133

thick-thighed, 89

Stink glands of Bugs, 105

Stomoxys calcitrans, 310

Stone Hy, 76

Straight wings, 82

Stratomyidæ, 12, 295

Stratomys chameleon, 296

sp., 295

Strepsiptera, 11, 220

Strongylium sp., 204

Stylopidæ, 11, 220

Stylopization, effects of, 221

Surra, 310

Symbiosis, 35

of Phenax auricoma, 120

Sympetrum scoticum, 75 sp., 65

Syrphidæ, 12, 303

Syrphus seleniticus, 304

Tabanidae, 12, 57, 237, 301

larvæ of, 297

Tabanus bovinus, 297

Tachinidæ, 13, 56, 308, 309, 310

Tanypus sp., 290

Tapinoma erraticum, 274

Telophorus lividus, 200

pellucidus, 200

rusticus, 200

Tenebrio molitor, 203

Tenebrioides mauritanicus, 194

Tenebrionidæ, 11, 54, 174, 203, 204

Tent caterpillar, 172 maker, 53

Tenthredinidæ, 12, 55, 225

Termes bellicosus, 185

flavipes, 80

lucifugus, 80

tubiformans, 80

Termite, 20, 29, 30, 78, 185, 192, 223 castes, 82 


\section{INDEX}

Tormite, cleanliness of, 82 colony, s0

Nasuti, 82 uuptial flight, 80

Queen, 81 soldiers, 82 workers, 82

Termitidæ, 8, 78, 100

Termitoxeniidæ, 20

Tetramorium caspitum, 275

Tettix sp., 96

Thanasimus formicarius, 200

T'hecla betuloe, 147

pruni, 147

quercus, 147

rubi, 43, 147

w-album, 147

Thripidæ, 8, 102

Thrips, 102 structure of, 102

Flax, 103

Orange, 103

Pea, 103

Pear, 103

Thyatira batis, 153 derasa, 153

Thynnidæ, 12, 259

Thysanoptera, 8, 52, 55, 102

Thysanura, 8, 18, 60

Tick, Sheep, 314

Timarcha tenebricosa, 210 turbida, 210

Tinea biselliella, 172 pellionella, 172 tapetzella, 171 vastella, 172

Tineidæ, 10, 53, 54, 171, 233

Tingidæ, 9, 55, 109

Tingis pyri, 109

Tiphia sp., 260

Tipula brobdignagia, 291 oleracea, 291

Tipulidæ, 12, 54, 291

Titanus giganteus, 175, 213

Titenacris albipes, 96

Tortricidx, 10, 53, 171

Tortrix ribeana, 171 viridana, 171

Tree weeping, 122

Tremex columba, 227 Pigeon, 227

Trichacis sp., 233

Trichins fasciatus, 1S2
Trichodectidæ, 8, 62

Trichodes alvearius, 200 apiarius, 200

Trichoptera, 9, 17, 134, 170

Trichroism, 145

Triungulin, 21, 22

Trochilium crabroniformis, 48,154

Trogositidæ, 11, 194

Trox sp., 180

Truxalis sp., 96

Trypanosoma brucei, 311 gambiense, 311

Trypetidæ, 13, 313

Trypodendron domesticum, 279 lineatum, 219

Trypoxylon sp., 236

Tubulifera, 12, 224, 234

Turnip flea, 211 fly, 211

Tussore silk, 150

Types of patterns, 48

Ugimyia serricaria, 309

Vanessa antiqua, 143

atalanta, 142

c-album, 142

cardui, 142

io, 142

polychloros, 142

urticae, 141

Variation, 30

Velleius dilatatus, 192

Velia currens, 111

Vermileo degeeri, 296

Vespa arborea, 255

austriaca, 255

crabro, 48, 255

germanica, 255

norvegica, 255

rufa, 255

sylvestris, 255

vulgaris, 255

Vespidæ, 12, 253, 255

Viviparous insects, 19

Volucella bombylans, 305 inanis, 303, 304

sp., 256

Wasp, 29, 123, 130, 192, 194, 221, 223, 236,253

Digger, 56, 237, 257 
Wasp, food of larvæ, 256 fossorial, $56,237,257$

Mud, 235, 253

parasites of, 256

Potter, 235, 258

prey of Robber flies, 301

Ruby, 234, 240

Sand, 264

Social, 56, 222, 255 nests of, 255

Solitary, 253

Wood, 227, 229

Blue, 227

Giant, 227

Water Boatman, 116

Cricket, 111

Gnat, 110

Grampus, 128

Measurer, 110

Scorpion, 115 eggs of, 115

Stick insect, 115

"Waves," 164

Webs of Dance fly, 301

Weeping trees, 122

Weevil, 173, 215

Acorn, 216

Apple blossom, 217

Birch, 217

Biscuit, 198
Weevil, Cotton Boll, 46, 216 Grain, 217

Nut, 216

Palm, 218

Pea, 206

Pine, 216

Plum, 217

Pice, 217

Wet season forms, 26

White Ant, 79 as food, 79

White fly, 104, 125

"Whites," 148

Wintering of insects, 26

Wireworms, 201, 204

Worm-eaten wood, 198

Xenopsylla cheopis, 281

Xenos sp., 222

Xestobium domesticum, 198 tessellatum, 198

Xyleborus dispar, 219

Xylocopa violacea, 245

Zaitha sp., 116

Zeugloptera, 8, 9

Zeuzera pyrina, 156

Zoraptera, 8

Zygona filipendula, 154

Zyganida, 10, 154 



$$
\begin{aligned}
& \text { PROPERTY OF } \\
& \text { Z. P. METC }
\end{aligned}
$$




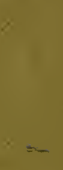

$=$

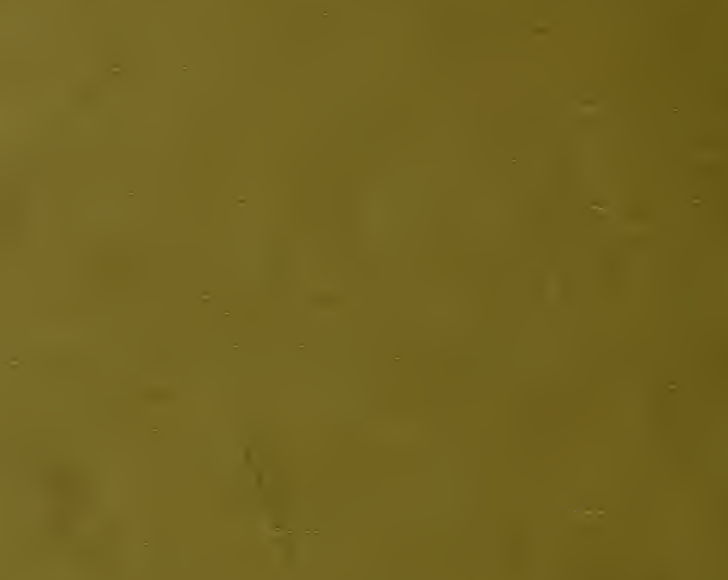

